UNIVERSIDADE DE SÃO PAULO

FACULDADE DE FILOSOFIA, LETRAS E CIÊNCIAS HUMANAS

DEPARTAMENTO DE SOCIOLOGIA

PROGRAMA DE PÓS-GRADUAÇÃO EM SOCIOLOGIA

ILAN LAPYDA

\title{
A “financeirização" no capitalismo contemporâneo: Uma discussão das teorias de François Chesnais e David Harvey
}

São Paulo

2011

(Versão Corrigida) 
UNIVERSIDADE DE SÃO PAULO

FACULDADE DE FILOSOFIA, LETRAS E CIÊNCIAS HUMANAS

DEPARTAMENTO DE SOCIOLOGIA

PROGRAMA DE PÓS-GRADUAÇÃO EM SOCIOLOGIA

\section{A “financeirização" no capitalismo contemporâneo: Uma discussão das teorias de François Chesnais e David Harvey}

Dissertação apresentada ao Programa de Pós-Graduação em Sociologia do Departamento de Sociologia da Faculdade de Filosofia, Letras e Ciências Humanas da Universidade de São Paulo, para a obtenção do título de Mestre em Sociologia.

Orientador: Prof. Dr. Ricardo Musse

São Paulo

2011

(Versão Corrigida) 


\section{Folha de Aprovação}

\section{Ilan Lapyda}

A "financeirização" no capitalismo contemporâneo: Uma discussão das teorias de François Chesnais e David Harvey

Dissertação apresentada à Faculdade de Filosofia, Letras e Ciências Humanas da Universidade de São Paulo para obtenção do título de mestre.

Área de concentração: Sociologia

Aprovado em:

1

Banca examinadora:

Prof(a). Dr(a).

Instituição:

Assinatura:

Prof(a). Dr(a).

Instituição: Assinatura:

Prof(a). Dr(a).

Instituição: Assinatura: 
Aos meus pais, por simplesmente tudo.

À minha vó Ana, por sua doçura até o fim.

A todos que amo, por darem sentido às agruras da investigação sociológica. 


\section{Agradecimentos}

É árdua a tarefa de reconstruir as contribuições para um trabalho como esse, que, de modo algum, remonta a apenas dois anos e meio atrás. Peço, portanto, compreensão pelas possíveis e involuntárias omissões.

Agradeço, assim:

Ao Prof. Ricardo Musse, não só pela orientação, mas pela participação valiosa, de longa data, em minha formação.

Aos professores Leda Paulani e Ruy Braga, pelos comentários na qualificação e por aceitarem o convite para a banca de defesa. Destaco a importância do curso de pós-graduação da professora Leda para a construção do projeto e desenvolvimento da pesquisa.

Aos meus professores na graduação e na pós, pelo que somaram ao meu percurso intelectual. Em especial a Sylvia Garcia e Alvaro Comin, que me iniciaram na realização de pesquisas durante o PET. Agradeço, assim, também aos colegas deste grupo, vários dos quais se tornaram grandes amigos.

Aos funcionários do Departamento de Sociologia, sobretudo Angela e Vicente, pelo apoio.

Aos meus familiares, pelo carinho. Em especial aos meus pais, Leila e René, pelo suporte amoroso, compreensão, confiança, incentivo, leituras do texto...

À Aninha, pelo afeto e dedicação e por entender meus inúmeros fins de semana de estudos.

Aos meus “anjos da guarda”, Eurides e Liu.

À Maria Rita, pela interlocução privilegiada.

A grandes amigos que não caberia situar em uma ou outra dimensão da minha vida.

Aos da "Velha Guarda": André, Bernardo, Fernando, Régis e Rodrigo, cujo papel em minha trajetória é indiscernível dela própria.

E aos "recentes", que conheci na Sociais: Carlitos, Clarissa, Erêndira, Fabinho, Maria, Natalita, pelos caminhos e reflexões fundamentais que compartilhamos.

Ao Danibas, amigo das antigas e colega de intercâmbio na Paris X.

À Paulinha Cerruti, malgrado a distância, por manter viva a esperança na transformação.

A Natália Castro, entre outros aportes, pelas indagações, advindas de nossas conversas, que influíram na escolha do tema da pesquisa.

A Clarisse Coutinho, pelas conversas e estudos. 
Aos participantes do antigo grupo de estudos d' $O$ Capital e do Lemarx, em especial aos queridos Bruna, Caio (grande companheiro, inclusive na APG), Edu Altheman, Fábio Pimentel, Ugo e Vladimir.

Também aos membros do GE-Marx, pelos tão preciosos "três tempos" nos fins de semana: Ana Luzia, André Reinach, Contier, Edu Fernandes, Forró, Gabi, Lucas Keese e Zé Luiz. O grupo se foi, mas de modo algum a amizade.

Aos companheiros na coordenação da APG/USP-Capital, em especial a Ester, Felipe, Lucas Brandão, Pati Magalhães, Rica e Stefan por "somarem olhares" comigo, nas palavras do Lucas.

Aos colegas e amigos do Núcleo de Estudos de Língua Estrangeira, pela oportunidade de participar de mais uma coletividade e de exercer a docência, e, em especial, à Marina pela troca de experiências.

Aos colegas de mestrado na disciplina Seminário de Projetos, pelos comentários.

A Annick Donniou e Adnan Nassani pela revisão das traduções do resumo.

Aos professores e amigos da dança de salão, pela ajuda em manter o equilíbrio e a compreender que corpo e mente não estão separados, a alegria de ambos sendo uma só.

Não posso deixar de agradecer também a duas instituições, o CNPq e a FAPESP, pelo apoio material à realização da pesquisa. 


\section{Resumo:}

A dissertação procura compreender o fenômeno da "financeirização" no âmbito do capitalismo contemporâneo. Uma série de transformações iniciadas nos anos 1970 assinalou o declínio do regime de acumulação "fordista" e a provável emergência de uma nova fase do capitalismo. Sua característica fundamental consiste em um movimento de "financeirização", decorrente em parte de mudanças desenvolvidas na esfera financeira. Seus traços mais destacados são o aumento exponencial das transações, tanto em termos absolutos como em relação às atividades produtivas; a liberalização e desregulamentação de mercados e das atividades financeiras em todo o mundo; o surgimento de novos agentes e instituições ligados às finanças. Processo este que desembocou no aumento da importância do capital financeiro nos circuitos de valorização.

O caráter recente deste fenômeno ainda não permitiu que fossem estabelecidos consensos teóricos sobre a questão. Por conta disso, a dissertação debruça-se sobre as obras de dois pensadores marxistas, François Chesnais e David Harvey, buscando estabelecer semelhanças, diferenças e, sobretudo, as complementaridades de suas contribuições. A escolha de Chesnais se impõe pelo papel destacado que o assunto ocupa em sua obra. Harvey, por sua vez, concede primazia à discussão das relações das finanças com os demais aspectos que caracterizam o capitalismo na atualidade.

Palavras-chave: François Chesnais, David Harvey, Marxismo, Financeirização, Capitalismo Contemporâneo. 


\begin{abstract}
:
The dissertation seeks to understand the phenomenon of "financialization" under contemporary capitalism. A series of transformations started in the 1970's which began out the decline of the "Fordist" regime of accumulation and the possible emergence of a new phase of capitalism. Its key feature is a movement of "financialization", which results in part from changes in the financial sphere. Its distinctive aspects are the exponential increase in transactions, both in absolute terms and in comparison to productive activities; liberalization and deregulation of financial markets and activities around the world; the emergence of new actors and institutions related to finance. This process led to an increased importance of financial capital in the circuits of valorization.

This new moment has not yet allowed to establish a theoretical consensus on the issue. For this reason, the dissertation focuses on the works of two Marxist thinkers, François Chesnais and David Harvey, seeking to establish similarities, differences and, above all, complementarities of their contributions. Choosing Chesnais is imposed due to the prominent role the subject occupies in his work. Harvey, in turn, prioritizes the discussion of relations between finance and other aspects of capitalism today.
\end{abstract}

Key-words: François Chesnais, David Harvey, Marxism, Financialization, Contemporary Capitalism. 


\section{Résumé:}

Ce texte a pour but de comprendre le phénomène de la «financiarisation» sous le capitalisme contemporain. Une série de transformations entamées dans les années 70 signalait déjà le déclin du régime d'accumulation «fordiste» et l'émergence probable d'une nouvelle phase du capitalisme. Sa principale caractéristique est un mouvement de «financiarisation» résultant en partie des changements opérés dans la sphère financière. Ses traits les plus saillants sont l'augmentation exponentielle des transactions, aussi bien en termes absolus que par rapport aux activités productives ; la libéralisation et la déréglementation des marchés et des activités financières partout dans le monde ; l'émergence de nouveaux acteurs et institutions liés à la finance. Ce processus a débouché sur un accroissement de l'importance du capital financier dans les circuits de valorisation.

Le caractère récent de ce phénomène n'a toujours pas permis d'établir de consensus théorique sur la question, de sorte que ce travail-ci se centre sur les œuvres de deux penseurs marxistes, François Chesnais et David Harvey, en cherchant à établir les similitudes, différences et surtout complémentarités de leurs contributions. Le choix de Chesnais s'est imposé en raison du rôle prépondérant que le sujet joue dans son travail. Harvey, à son tour, donne la primauté à la discussion des rapports entre la finance et les autres aspects qui caractérisent le capitalisme d'aujourd'hui.

Mots-clé: François Chesnais, David Harvey, Marxisme, Financiarisation, Capitalisme Contemporain. 
"Há, portanto, um vínculo constitutivo entre dinamismo tecnológico, instabilidade, dissolução de solidariedades sociais, degradação ambiental, desindustrialização, aceleradas mudanças das relações tempoespaço, bolhas especulativas e a tendência geral de formação de crises no capitalismo" David Harvey, O novo imperialismo

"Numa depressão, os ativos retornam a seus legítimos proprietários"

Frase atribuída a Andrew Mellon, banqueiro norteamericano, republicano e ex-secretário do Tesouro dos EUA. 


\section{Sumário}

Introdução

Parte I - François Chesnais: Regime de acumulação com dominância financeira ................................................................................................................................ 26

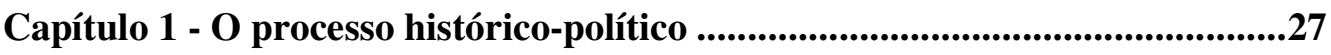

Capítulo 2 - Aspectos econômicos.................................................................................49

Capítulo 3 - $\mathrm{O}$ regime financeirizado ......................................................................90

Parte II - David Harvey: acumulação 'flexível', neoliberalismo e imperialismo .............................................................................................................. 104

Capítulo 4 - Financeirização e regime 'flexível' de acumulação..........................105

Capítulo 5 - Financeirização e neoliberalismo .......................................................121

Capítulo 6 - Financeirização e imperialismo ............................................................137

Capítulo 7 - A teoria das finanças..............................................................................161

Observações finais..................................................................................................... 185

Anexo 1 - Breves notas sobre o regime de acumulação fordista .................. 206

Anexo 2 - Termos e Conceitos .................................................................... 210

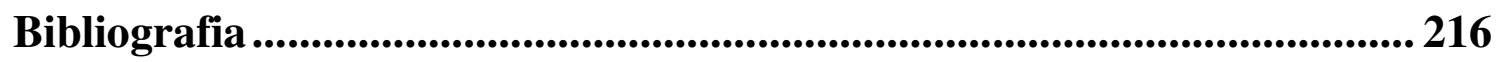




\section{INTRODUÇÃO}

François Chesnais inicia assim o livro A mundialização financeira (1996):

O crescimento espetacular das transações financeiras foi um dos fatos mais significativos da década de 80 e já marcou os primeiros anos da década de 90. Efetivamente, a esfera financeira representa a ponta-de-lança do movimento de mundialização da economia; é nessa esfera que as operações do capital envolvem os montantes mais elevados; é aí que sua mobilidade é maior; é aí que, aparentemente, os interesses privados recuperam mais completamente a iniciativa, em relação ao Estado. ${ }^{1}$

Inúmeros teóricos de diversas áreas do conhecimento já identificavam, desde os anos 1970, uma retomada de princípios liberais - movimento denominado neoliberalismo e encarnado simbolicamente nas figuras de Margareth Thatcher e Ronald Reagan. Essa retomada se deu em contraposição ao relativo controle, especialmente sobre a circulação do capital em nível mundial, predominante no período de vigência dos acordos de Bretton Woods - extinto definitivamente em 1971, quando Richard Nixon abandona unilateralmente a conversibilidade do dólar e o lastro ouro. Nesse sentido, passa a ocorrer um volume cada vez maior de transações financeiras e com uma mobilidade em escala internacional inaudita. Chesnais mostra, com dados da Organização para a Cooperação e Desenvolvimento Econômico, que "de 1980 a 1992, a taxa média de crescimento anual do estoque de ativos financeiros foi 2,6 vezes maior do que da formação bruta de capital fixo do setor privado dos países da OCDE",2.

Números atualizados mostram a magnitude atingida por esse "inchaço" financeiro hoje. Leda Paulani ${ }^{3}$ apresenta dados que indicam a evolução dos ativos financeiros no mundo a partir dos anos 1980 e compara-os com a economia "real". Para um estoque mundial de ativos financeiros ${ }^{4}$ em torno de US\$ 12 trilhões e um PNB mundial de US\$ 11,8 trilhões

\footnotetext{
${ }^{1}$ CHESNAIS, A mundialização financeira, p. 11.

${ }^{2}$ Ibidem, p. 14.

${ }^{3}$ Cf. PAULANI, "A crise do regime de acumulação com dominância da valorização financeira e a situação do Brasil".

${ }^{4}$ Excetuando os mercados derivativos, cujos números a serem considerados são objeto de polêmica devido aos seus valores "nocionais".
} 
(relação de 1,02) em 1980, chega-se em 2006 a um estoque de ativos financeiros de US\$ 167 trilhões e um PNB de US\$ 48,8 trilhões (relação de 3,42). Ou seja, em 26 anos, o PIB mundial cresceu $314 \%$ (4,1 vezes o que era) enquanto a riqueza financeira mundial cresceu $1.292 \%$ $(13,9 \text { vezes o que era })^{5}$. Reproduzimos abaixo o gráfico, apresentado por Paulani:

Gráfico 1 - Riqueza fictícia (estoque mundial de ativos financeiros) e renda real mundial (PNB) US\$ trilhões.

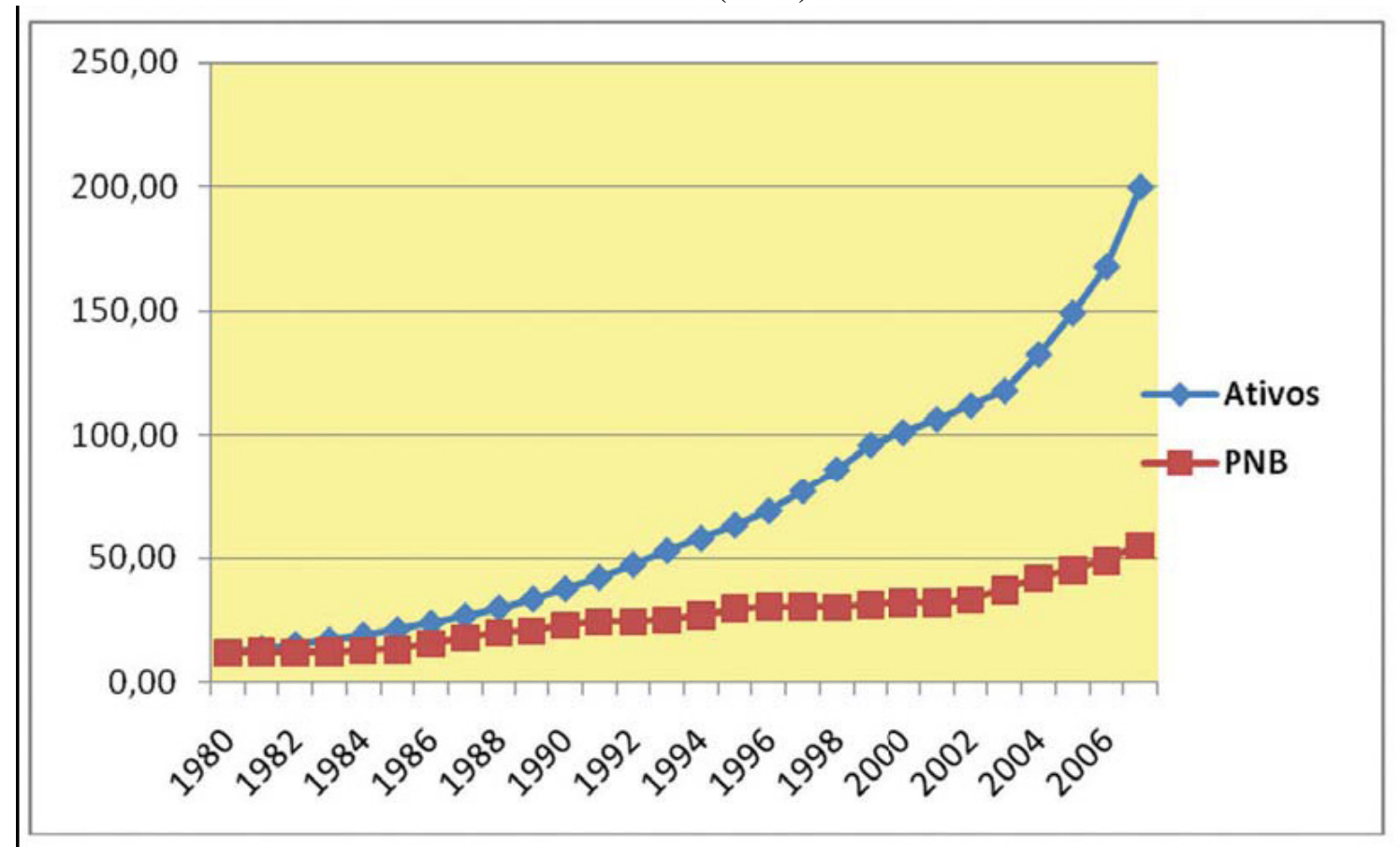

Fonte: McKinseys Global Institute (Ativos) e FMI (PNB); elaboração própria [de Leda Paulani]. Obs.: Para a construção do gráfico, os valores do estoque mundial de ativos financeiros correspondentes aos anos para os quais [não] há dados disponíveis foram estimados como crescendo a uma taxa constante.

De todo modo, a fim de se ter uma idéia, para um PIB mundial girando em torno de US\$ 65 a 70 trilhões, o "valor nocional" dos derivativos - ou seja, a soma dos valores totais dos contratos negociados nesses mercados chega a ser de 9 a 10 vezes o PIB. Cf. NAKATANI e HERRERA, Crise financeira... ou de superprodução?, p. 17 , nota 34 .

${ }^{5}$ Números confirmados por Wolf: "a proporção de ativos financeiros mundiais em relação à produção anual disparou de 109\%, em 1980, para 316\% em 2005. Em 2005, o estoque mundial de ativos financeiros principais totalizou US\$140 trilhões" - Cf. WOLF, “O novo capitalismo financeiro provoca revolução global”. 
Ressalte-se aí o peso da ampliação da dívida pública dos Estados nacionais, uma das principais fontes de rendas financeiras. Veja-se o exemplo dos EUA:

\begin{tabular}{|c|c|c|}
\hline$\underline{\text { Ano }}$ & Dívida pública (em US\$ trilhões) & Relação Dívida/PIB \\
\hline 1970 & 0,371 & $35,7 \%$ \\
\hline 1990 & 3,2 & $55,7 \%$ \\
\hline $2007 *$ & 9 & $64 \%$ \\
\hline 2009 & 12 & $83,3 \%$ \\
\hline \multicolumn{3}{|c|}{$\begin{array}{l}\text { Valores da dívida retirados de: http://www.treasurydirect.gov/govt/reports/pd/histdebt/histdebt_histo4.htm } \\
\text { Relações Dívida/PIB retiradas de: } \\
\text { http://www.usgovernmentspending.com/downchart_gs.php?year=1792_2010\&view=1\&expand=\&units=p\&fy=f } \\
\text { y11\&chart=H0- } \\
\text { fed\&bar=0\&stack=1\&size=1\&title=US\%20Federal\%20Debt\%20As\%20Percent\%20Of\%20GDP\&state=US\&col } \\
\text { or=c\&local=s\#copypaste }\end{array}$} \\
\hline
\end{tabular}

Em outros países desenvolvidos, a dívida também é elevada, sendo que, em alguns, chega a ultrapassar os $100 \%$ do PIB: "Segundo o FMI, a dívida bruta (...) do governo japonês é de $218,6 \%$, a do governo italiano é de $115,8 \%$, a do governo alemão é de $78,7 \%$, a do governo francês é de $76,7 \%$, a do governo canadense é de 78,2\% e a do Reino Unido é de $68,7 \% " 6$.

Além disso, a esfera financeira parece "autonomizar-se" em relação à base produtiva/material, seguindo uma lógica própria e imperscrutável. Donde a proliferação de expressões fetichizadas acerca do mercado financeiro como o mercado está "nervoso", "agitado", "cauteloso". Os sentimentos de incompreensão, instabilidade e desorientação parecem distintivos do período atual do capitalismo, possibilitando inclusive manipulações midiáticas. As crises, então, parecem dotadas de uma natureza obscura, podendo ocorrer de forma inesperada, produzindo estragos não só financeiros, mas também sociais - diretos e

\footnotetext{
${ }^{6}$ NAKATANI e HERRERA, Crise financeira... ou de superprodução?, p. 16.
} 
indiretos - de grandes proporções. Entre estes, podem-se citar o aumento da pobreza, a diminuição e precarização do emprego e a redução ou extinção de direitos sociais conquistados anteriormente.

Essa hipertrofia do sistema financeiro (com uma multiplicação desenfreada de produtos financeiros, cuja utilidade e finalidade são, em muitos casos, dificilmente compreensíveis aos leigos) parece associada a um conjunto de transformações organizacionais no âmbito do processo produtivo. Essas modificações derivam da introdução e adoção em grande escala do paradigma "flexível”, também conhecido por "pós-fordista”, já abordado por uma vasta literatura. A passagem de uma estrutura "pesada" - que tentava abarcar todas as etapas da produção das mercadorias, operando com grandes estoques e grande quantidade de força de trabalho - para uma estrutura "flexível”, mais especializada e que busca se desincumbir de uma série de encargos, mostra-se mais adequada às exigências da "preferência pela liquidez", típica da lógica financeira hegemônica.

Por outro lado, alguns autores apresentam dados ou mesmo teorias que relativizam a idéia de "financeirização" como um fenômeno sem precedentes do capitalismo, ou então a concebem de outro modo. Barry Eichengreen, por exemplo, em sua análise da história do padrão ouro, destaca que "antes da Primeira Guerra Mundial, não existiam controles sobre transações financeiras internacionais e os fluxos de capital internacionais alcançavam níveis elevados"7.

No campo do marxismo, por sua vez, são encontradas no mínimo duas correntes divergentes. Uma, representada por Eleutério Prado e bem exposta em sua resenha sobre $A$ finança mundializada, critica a tese da dominância financeira de Chesnais. Prado contesta principalmente a questão da "valorização financeira", já que o capital fictício não possui base material que lhe permita valorizar-se de forma independente. A autonomização da esfera financeira seria, portanto, apenas uma aparência, na medida em que "o capital não pode se valorizar só na esfera financeira, a não ser fictícia e temporariamente" ${ }^{\wedge}$, tendo que penetrar em algum momento na produção. Prado sugere que as análises que se concentram na hipertrofia da esfera financeira são tributárias do fetichismo do capital.

Prado localiza na esfera produtiva, nas formas de produção, as raízes do fenômeno da "financeirização", por mais paradoxal que isso pareça. A partir de uma interpretação dos

\footnotetext{
${ }^{7}$ Cf. EICHENGREEN, A globalização do capital, p. 23.
}

${ }^{8}$ PRADO, "Resenha de 'A finança mundializada'”, p. 221. 
Grundrisse, de Marx, ele adota o conceito de "pós-grande indústria" de Ruy Fausto, para defender a tese de que ocorreu uma mudança interna ao modo de produção das mercadorias ${ }^{9}$. A inserção da ciência e da tecnologia no cerne do ciclo produtivo tendo se tornado fator crucial na produção de valor, emergiu uma mudança qualitativa no modo de valorização do valor: empresas como a Microsoft, por exemplo, se apropriariam de "rendas do conhecimento", como Eleutério denomina, de forma semelhante ao rendimento do capital portador de juros.

Rodrigo Teixeira ${ }^{10}$ prolonga a polêmica ao promover uma "crítica da crítica", na qual defende as posições de Chesnais contra as objeções de Prado. Ele sugere que este teria adotado uma perspectiva um pouco estreita sobre o capital portador de juros, atendo-se à sua forma original, básica: dinheiro que é emprestado, empregado na produção e devolvido acrescido de parte da mais valia - a fórmula D-[D-M-D']-D'11. A negligência do princípio da capitalização descrito pelo próprio Marx e, com ele, do potencial do capital fictício, impediu a percepção da existência de uma forma de valorização do capital que não passa diretamente pela produção de mercadorias.

Outra corrente que discrepa da tese da dominância financeira é a da teoria dos ciclos de longa duração, capitaneada por Giovanni Arrighi. Não se nega a existência de "expansões financeiras". Ao contrário, Arrighi as concebe explicitamente "como longos períodos de transformação fundamental do agente e da estrutura dos processos de acumulação de capital em escala mundial"12. Contudo, ele parte da perspectiva braudeliana da história (longue durée) e do capitalismo que o leva a não considerar a "financeirização" como uma etapa nova do capitalismo. Recuando ao século XV, distingue desde então a ocorrência de quatro "ciclos sistêmicos de acumulação" do capital em escala mundial. Cada um deles tem duração superior a um século e possui um centro hegemônico ${ }^{13}$ diferente.

Fazendo um paralelo com a fórmula do capital criada por Marx (D-M-D'), Arrighi define cada ciclo sistêmico de acumulação como uma fase de expansão material (D-M) seguida de uma fase de expansão financeira (M-D’):

\footnotetext{
${ }^{9}$ Para se compreender a visão de Prado sobre o capitalismo contemporâneo, ver PRADO, A desmedida do valor.

${ }^{10}$ Cf. TEIXEIRA, Dependência, desenvolvimento e dominância financeira, cap. 3.

11 "Trata[-se] em efetivo de uma operação externa que pressupõe justamente a penetração posterior do capitaldinheiro no ciclo D - M - D"” - PRADO, "Resenha de 'A finança mundializada"”, pp. 220 e 221,

${ }^{12}$ ARRIGHI, $O$ longo século $X X$, p. 88 ,

${ }^{13}$ Hegemonia mundial, segundo palavras do próprio autor, refere-se "à capacidade de um Estado exercer funções de liderança e governo sobre um sistema de nações soberanas” - Ibidem, p. 27.
} 
Nas fases de expansão material, o capital monetário ‘coloca em movimento' uma massa crescente de produtos (que inclui a força de trabalho e dádivas da natureza, tudo transformado em mercadoria); nas fases de expansão financeira, uma massa crescente de capital monetário 'liberta-se' de sua forma mercadoria, e a acumulação prossegue através de acordos financeiros (como na fórmula abreviada de Marx, DD'). ${ }^{14}$

As "altas finanças", em sua forma moderna e capitalista, teriam sido invenção dos florentinos, cuja lógica era a de que o capital só deveria continuar a ser investido no comércio e na produção, não apenas se houvesse algum lucro, mas que este fosse maior que o que poderia ser obtido em transações financeiras (cujo processo de valorização demanda menos esforços e possui maior liquidez). Nesse sentido, uma fase de expansão financeira se segue a uma fase de expansão material quando emerge uma crise geral de sobreacumulação do capital. Ela é o primeiro sintoma dessa crise e se inicia quando o capital já não pode ser reinvestido de forma a obter a mesma lucratividade, migrando para a esfera financeira - em busca de lucros maiores.

Dessa forma, apoiando-se numa história de longa duração, Arrighi está em condições de conferir um sentido "geral" à "financeirização". Contudo, o que se ganha com a generalização, se perde em detalhes, não sendo possível identificar em sua obra as especificidades nem os mecanismos próprios que operam no período atual de expansão financeira. Não apresenta, portanto, instrumentos que permitam lidar com as questões da mundialização financeira listadas por Chesnais, a saber:

\footnotetext{
As circunstâncias de sua gênese, (...) o papel das instituições financeiras específicas, (...) os mecanismos que regem a evolução das próprias características da moeda nesse novo contexto, (...) e sobretudo, as consequiências mais importantes da mundialização das finanças para o funcionamento da economia mundial. ${ }^{15}$
}

Por conta dessas divergências e nuances em torno do fenômeno da "financeirização", no intuito de simplificar a exposição será utilizado, ao longo do texto, o termo "financeirização" (o qual não mais estará entre aspas, que estarão pressupostas) de forma ampla. Ele servirá para designar esse movimento de intensificação dos processos financeiros que caracteriza o período recente do capitalismo, iniciado nos anos 1970, sem, contudo, remeter a um autor ou enquadramento teórico específico.

\footnotetext{
${ }^{14}$ ARRIGHI, O longo século $X X$, p. 6.

${ }^{15}$ CHESNAIS, A mundialização financeira, p. 11.
} 
As transformações ocorridas nas últimas quatro décadas indicam uma mudança, e talvez mesmo uma ruptura, com relação ao período precedente - chamado geralmente de “fordismo". Porém, a contemporaneidade do fenômeno da financeirização coloca inúmeros problemas quanto ao melhor modo de concebê-lo teoricamente, suscitando dúvidas sobre quais conceitos utilizar para apreendê-lo e até mesmo se é possível afirmar seu ineditismo ou sua especificidade. Não fica claro de imediato o quão nova é a situação por que passa o capitalismo hoje e quais são suas características distintivas.

Nesse sentido, pereceu-me importante empreender um balanço das teorias sobre a financeirização. Tarefa realizada no âmbito do marxismo, e, dada a impossibilidade de analisar toda a literatura sobre o tema, concentrei-me mais na discussão das obras de dois autores: François Chesnais e David Harvey.

A escolha de autores da linhagem do marxismo se deu por conta de dois fatores principais. Primeiro, às insuficiências de outras teorias, sobretudo da economia ortodoxa. Esta, na realidade, não possui propriamente uma teorização sobre as atividades financeiras, que são concebidas, de forma naturalizante, como simplesmente um outro setor de investimentos. A teoria econômica corrente se especializou em descrever e apreender o funcionamento dos mercados financeiros, do sistema de crédito, etc. sem olhar para a totalidade do sistema capitalista. Desse modo, não pode compreender a fundo o papel que o capital financeiro desempenha nesse sistema.

O segundo fator determinante na opção pela teoria marxista reside no seu potencial reflexivo. Além de explicar adequadamente o fenômeno da financeirização - relacionando-o aos fundamentos do capitalismo e sua natureza contraditória - e de desvendar o caráter das crises, o marxismo permite interpretar a financeirização agregando outros pontos de vista, como o sociológico, o histórico e o político. Exatamente por ser mais que uma mera teoria econômica, permite reunir organicamente na análise os mais diversos aspectos: o processo político de constituição da financeirização, o papel dos governos e de outros atores políticos, as transformações da estrutura econômica, a relação entre capital e trabalho, o fetichismo que se intensifica na sociedade, o mecanismo subjacente ao funcionamento das Bolsas, entre outros. 
Marx fornece, assim, conceitos e caminhos teóricos fundamentais, sendo central neste trabalho. Dentre os pontos que destaca, mas que necessitam de desenvolvimentos, figura, por exemplo, a questão política. De um lado, em suas análises históricas empreendidas em $A s$ lutas de classes na França de 1848 a 1850 e no Dezoito Brumário de Louis Bonaparte, Marx analisa os conflitos políticos efetivos "intra-burguesia" na França dos anos 1840, decorrentes da disputa pela apropriação da mais-valia. O conflito principal se dava então entre a burguesia financeira, de um lado, e a burguesia industrial e fundiária, de outro, sendo os gastos estatais um dos pontos centrais da querela:

\footnotetext{
Impossível submeter a administração do Estado aos interesses da produção nacional sem restabelecer o equilíbrio orçamentário. (...) [Mas] o déficit do Estado era precisamente o verdadeiro objeto de suas [da burguesia financeira] especulações e a fonte principal de seu enriquecimento. ${ }^{16}$
}

De outro lado, Marx apresenta, em $O$ Capital, uma clivagem estrutural relativa à divisão da mais-valia em lucro e juro que permite entender melhor esse jogo político. $\mathrm{Na}$ ausência de uma taxa "natural" de juros, seus valores se movem segundo a conjuntura econômica, conforme o estado da disputa entre capitalista "ativo"/“produtivo" e capitalista "passivo"/"monetário""17 enquanto figuras que representam o lucro e o juro respectivamente. A generalização do capital portador de juros impinge, assim, uma cisão de ordem material no seio da burguesia.

Em $O$ Capital, a questão política não é abordada além desse patamar mais abstrato. $\mathrm{O}$ Estado, embora pressuposto, não aparece como um agente ativo. A análise se concentra na relação entre capitalistas (industriais e monetários) e trabalhadores, bem como na lógica de funcionamento do capital portador de juros. Atualmente, contudo, é notório o papel que governos e instituições internacionais possuem no jogo econômico e, sobretudo, financeiro, definindo regras, direcionando os investimentos e principalmente assumindo o papel de "emprestadores em última instância" - como nos casos de turbulências financeiras. Um olhar atento para o Estado torna-se então crucial para a compreensão não só do funcionamento do capitalismo financeirizado em si, mas também de como se chegou a ele.

\footnotetext{
${ }^{16}$ MARX, As lutas de classes na França de 1848 a 1850 in: MARX e ENGELS. Obras Escolhidas, Vol. I, p. 112 (grifo no original).

${ }^{17}$ Os termos entre aspas são do próprio Marx.
} 
Esses e outros pontos são abordados nas obras de Chesnais e Harvey, que se esforçam no sentido de desenvolver e atualizar a teoria de $\operatorname{Marx}^{18}$.

A obra de Chesnais foi selecionada principalmente pela importância que concede à financeirização. Grande parte dela dedica-se especificamente a compreendê-la (inclusive cunhando conceitos específicos para isso). Sua teoria permite obter um entendimento do tema ao mesmo tempo abrangente (pois trata dos aspectos gerais que definem a financeirização) e detalhado (uma vez que aborda também pontos específicos, não subsumindo a financeirização à discussão de outros assuntos).

Chesnais desenvolveu sua obra de forma bastante esparsa ${ }^{19}$, compondo diversos artigos e organizando coletâneas sobre o tema. Sobre o assunto, dispomos de apenas um livro inteiramente escrito por ele ${ }^{20}$. Nesse cenário, procurei sistematizar e apresentar os aspectos principais de sua teoria, visando depurar sua concepção do fenômeno da financeirização.

David Harvey, por sua vez, se impôs como um complemento à contribuição de Chesnais. Embora não trate especificamente do tema da financeirização, este sempre aparece relacionado a outras discussões, como na questão do imperialismo, do neoliberalismo e da pós-modernidade. Sua obra fornece elementos fundamentais para a compreensão da questão da financeirização a partir, sobretudo, da relação que esta possui com outros fenômenos próprios do capitalismo contemporâneo.

Há, porém, outras razões que justificam a escolha desses dois autores. Uma delas consiste no fato de eles não terem estabelecido um diálogo, apesar de suas afinidades: não consta que Harvey tenha citado Chesnais em seus principais textos e este apenas cita o primeiro marginalmente, às vezes em notas de rodapé. Isso talvez se deva ao fato de que - e isso é outro elemento que torna a comparação interessante - os autores estão inseridos em contextos intelectuais distintos: um é economista francês e o outro é geógrafo inglês (há muitos anos radicado nos EUA).

\footnotetext{
${ }^{18} \mathrm{O}$ esforço em atualizar a teoria de Marx nos mais diversos sentidos sempre foi uma preocupação legítima do marxismo. Os frankfurtianos, por exemplo, esforçaram-se para compreender os efeitos da monopolização do capitalismo, integrando à análise outros elementos. Para isso, Max Horkheimer propôs, nos anos 1930, um "materialismo interdisciplinar" capaz de conjugar diversos campos do conhecimento. Cf. HORKHEIMER, "A presente situação da filosofia social e as tarefas de um Instituto de Pesquisas Sociais" e Idem., "Teoria tradicional e teoria crítica".

${ }^{19}$ Além de não estar acabada, já que Chesnais continua escrevendo.

${ }^{20}$ Trata-se de $A$ mundialização do capital, o seu livro mais antigo sobre o tema e no qual a questão da financeirização era ainda bastante incipiente.
} 
Um ponto em comum entre os autores, além da filiação ao marxismo, é sua relação com a escola francesa da regulação. Nenhum dos dois pode ser classificado propriamente como "regulacionista", mas ambos se aproximaram dessa corrente em determinada fase de seus respectivos trabalhos. Essa "coincidência" se explica em parte pelo papel desempenhado pela escola da regulação no debate sobre a mudança do capitalismo iniciada nos anos 1970, tendo influenciado diversos autores ${ }^{21}$ - inclusive no campo do marxismo.

Desse modo, empregar o "vocabulário" da escola da regulação não deixou de ser um modo de se inserir no debate. Porém, mais que isso, os conceitos regulacionistas foram forjados visando auxiliar na elaboração de uma análise mais "concreta" (menos abstrata e geral) do capitalismo, de forma a poder captar com mais acuidade suas mudanças. O intuito inicial era, pois, fazer a mediação entre os elementos mais estruturais do capitalismo (que o constituem como modo de produção) e as formas históricas específicas por ele assumidas (modos de desenvolvimento). Cabe observar que o conceito regulacionista mais empregado por Chesnais e por Harvey é o mesmo: "regime de acumulação".

Assim, embora Chesnais se concentre na idéia de "mundialização financeira", deixa transparecer na análise da financeirização, sobretudo em seus textos da década de $1990^{22}$, a sua preocupação com alguns dos elementos que compõem o "regime de acumulação" e mesmo as "formas institucionais" regulacionistas. Talvez porque esses fatores ajudem na definição das características da financeirização, na medida em que revelam a forma específica assumida pela acumulação de capital, bem como as transformações que esta provoca na sociedade.

O conceito de "regime de acumulação" permite também, segundo Chesnais, estender e aprofundar o que estava contido nos trabalhos marxistas do início do século $\mathrm{XX}$ sobre o imperialismo, a saber: o esforço de inscrever o movimento da acumulação na história - da luta de classes e da relação entre os Estados - e na política (concebida como história em processo $)^{23}$. No emprego do termo, Chesnais reconhece ainda uma "dívida": "Considero que, no final dos anos 1970, os regulacionistas lançaram às correntes marxistas 'ortodoxas' da época, mas também a um corpus marxiano profundamente mumificado, um desafio sério e

\footnotetext{
${ }^{21}$ A pluralidade de trabalhos aos quais a escola da regulação deu origem levou Michel Aglietta a afirmar que "devemos falar em uma abordagem ao invés de uma teoria. O que ganhou aceitação não foi um corpo de conceitos perfeitamente refinados, mas um programa de pesquisa" - AGLIETTA, A Theory of Capitalist Regulation, p. 388.

${ }^{22}$ Até seu texto de 2001 (em Uma nova fase do capitalismo?).

${ }^{23}$ Cf. CHESNAIS, "La théorie du regime d'accumulation financiarisé: contenu, portée et interrogations", pp. 10 e 11 .
} 
enriquecedor" ${ }^{\text {,24 }}$, que teve como resultado uma renovação e certa revitalização do marxismo na França.

Chesnais não deixa, no entanto, de ressaltar as limitações dessa abordagem. Sua base teórica marxista impede-o de adotar as noções regulacionistas sem crítica e ele afirma utilizar o conceito de regime de acumulação de modo diverso. Além disso, o caráter instável e contraditório da financeirização põe em xeque os critérios regulacionistas para se definir um regime de acumulação, e, sobretudo, um modo de regulação. De todo modo, Chesnais nem tem a intenção de estabelecer um modo de regulação funcional. Em última instância, a noção de "estabilidade" é estranha ao marxismo (ainda que os equilíbrios para a escola da regulação sejam dinâmicos e não estáticos) devido ao dinamismo inerente às contradições. Há momentos em que estas estão mais contidas devido a vários fatores. Porém, a lógica do capitalismo sempre aponta para sua superação, como sugere Chesnais:

De um ponto de vista marxista, a 'superação dos limites imanentes', que se materializam na forma particular de 'construção social' representada por um regime de acumulação, nunca poderá conduzir a algo além de uma estabilização temporária das condições de acumulação e da reprodução social dominante fundada na propriedade privada. As contradições fundamentais e os limites imanentes da produção capitalista se reafirmarão cedo ou tarde, às quais se somarão as condições próprias de um dado regime de acumulação. ${ }^{25}$

Comparada com Chesnais, a relação de Harvey com a escola da regulação é mais intensa, no entanto, pontual. Em Condição pós-moderna, Harvey afirma explicitamente fazer uma análise em termos regulacionistas das transformações político-econômicas do capitalismo no final do século XX. Ele adota a "linguagem" e a "hipótese" regulacionistas, pelo menos como "recurso heurístico" 26 . Tal abordagem teria ainda, segundo ele, o mérito de permitir particularizações históricas e geográficas do capitalismo.

Por outro lado, no mesmo livro, Harvey assume que naquele momento era prematuro afirmar se realmente as mudanças que se processavam estariam levando a um novo regime de acumulação e a um novo modo de regulação ${ }^{27}$. Além disso, ele delineia uma crítica: haveria "na escola da regulação pouco ou nenhum esforço para fornecer uma compreensão detalhada dos mecanismos e da lógica das transições - o que me parece uma séria falha" ${ }^{\text {28 }}$.

\footnotetext{
${ }^{24}$ CHESNAIS, "La théorie du regime d'accumulation financiarisé (...)”, p. 10.

${ }^{25}$ Ibidem, p. 12.

${ }^{26}$ HARVEY, Condição pós-moderna, p. 117.

${ }^{27}$ Cf. Ibidem, p. 119.

${ }^{28}$ Ibidem, p. 164.
} 
Em livros subseqüentes essa ambigüidade se dissipa e Harvey abandona a linguagem regulacionista e a referência direta a seus autores (diferentemente de Chesnais, que aos poucos marginaliza os conceitos regulacionistas mas não os suprime completamente). Embora Harvey não exponha claramente os motivos ${ }^{29}$, isso provavelmente se deve a diversos fatores, entre eles o aprofundamento das críticas já presentes em Condição pós-moderna, o enfoque das obras posteriores e o enfraquecimento da importância da escola da regulação no debate.

A ordem de apresentação da dissertação se coloca como uma questão de difícil solução. Devido ao caráter multifacetado da financeirização, muitos de seus elementos se pressupõem mutuamente para serem bem compreendidos. Provavelmente não é casual que Chesnais não tenha escrito um grande e metódico livro sobre o tema, mas artigos em periódicos e capítulos para obras coletivas, com a contribuição de diferentes autores. A apreensão fragmentada, "prismática", parece quase uma imposição do objeto.

Assim, a primeira Parte da dissertação foi composta em três capítulos. Procurei analisar de forma pormenorizada a teoria de François Chesnais sobre a financeirização ou, para utilizar seu conceito, sobre o "regime de acumulação com dominância financeira".

No Capítulo 1, procurei reconstituir o processo político e histórico de ressurgimento do "poder da finança" 30 em âmbito mundial. Ele corresponde ao movimento de mundialização financeira que se segue ao aprofundamento da mundialização do capital. Enfatizam-se as sucessivas etapas de liberalização e desregulamentação dos mercados empreendidas por governos e instituições internacionais, bem como o aparecimento de novos atores cruciais para o desenvolvimento do capitalismo contemporâneo.

Embora a dimensão "econômica" da financeirização seja indissociável desse movimento, ela foi tratada em separado, no intuito de facilitar a exposição. No Capítulo 2, destaquei o "funcionamento" do capital financeiro e a questão da mudança na acumulação do capital. Para isso, procurei retomar os principais elementos da financeirização apontados por

\footnotetext{
${ }^{29}$ Talvez por estar menos diretamente implicado no contexto intelectual francês do que Chesnais, Harvey não teve a mesma preocupação em comentar sua relação com a escola da regulação e seu afastamento dela.

${ }^{30}$ CHESNAIS, "O capital portador de juros: acumulação internacionalização, efeitos econômicos e políticos", p. 53.
} 
Chesnais, e também desenvolvendo uma breve discussão sobre o papel e o funcionamento das Bolsas. Por fim, as crises são abordadas na especificidade que assumem no período atual de instabilidades.

O Capítulo 3 foi elaborado como uma espécie de fecho da Parte I. O processo foi situar o regime financeirizado em seus diferentes sentidos. Primeiro, esbocei um resumo das características do atual regime, de forma a permitir uma comparação com o fordismo. Aproveitei a oportunidade para mostrar a crítica de Chesnais a Aglietta no que se refere ao novo período do capitalismo, situando este na discussão sobre um novo modo de desenvolvimento. Em seguida, comento alguns pontos da relação entre o regime financeirizado e o período anterior ao fordismo (que usualmente é invocado como um momento de força das finanças). Por fim, busquei situar o regime financeirizado no que tange ao próprio capitalismo.

Na Parte II, analiso os textos de David Harvey que considerei mais importantes para a compreensão de sua visão sobre a financeirização. Como Harvey não define o capitalismo contemporâneo a partir desta e tampouco possui uma teoria sistemática sobre esse fenômeno (embora este seja um elemento fundamental nos processos que ele descreve) procurei tratar a análise de Harvey sobre a financeirização nos diferentes contextos em que aparece, estabelecendo, sempre que possível, diálogos com a obra de Chesnais.

O Capítulo 4 concentra-se no exame do livro Condição pós-moderna. Procurei estabelecer as relações entre o regime "flexível" de acumulação definido por Harvey e a financeirização. Para isso, retomo os principais aspectos que compõem essa "flexibilidade", a questão da compressão e deslocamentos espaço-temporais e o papel que o capital financeiro desempenha nesse contexto.

O Capítulo 5 versa sobre a questão do neoliberalismo. Esse termo difundiu-se amplamente não só no meio acadêmico, mas também na mídia, de modo que, malgrado certas características gerais comumente associadas a ele, sua definição varia consideravelmente. Por conseguinte, um dos objetivos do capítulo consistiu em compreender como Harvey o concebe e quais as principais características que ele lhe atribui, incluindo os elementos que permitiram sua ascensão, bem como o que seria o Estado neoliberal. Desse modo, se torna possível estabelecer qual seria a nova situação político-institucional conferida ao capitalismo contemporâneo e como ela se relaciona com a financeirização. Por fim, comento a relação do neoliberalismo com um conceito importante na obra de Harvey - a "acumulação por espoliação". 
O Capítulo 6 trata da questão do imperialismo, ou seja, da relação entre os Estadosnações. Analisam-se os conceitos de hegemonia e imperialismo tal como concebidos por Harvey e a questão da sobreacumulação do capital. A idéia de deslocamentos espaçotemporais é retomada e faz-se uma análise pormenorizada do conceito de "acumulação por espoliação" em sua relação com a financeirização.

Por fim, o Capítulo 7 aborda Limits to Capital, a fim de obter elementos para uma melhor compreensão de alguns dos conceitos presentes nos capítulos anteriores. Intenta-se também apreender como Harvey concebe teoricamente os aspectos fundamentais das finanças, tais como o dinheiro, o sistema de crédito e o próprio capital financeiro.

Nas observações finais, procurei apenas retomar algumas das relações já apontadas sobre Harvey e Chesnais quanto à questão da financeirização, assim como complementá-las com outras insuficientemente tratadas. Nesse esforço, busquei expor alguns dos elementos que caracterizam a "perspectiva da financeirização" e que podem auxiliar na compreensão do capitalismo contemporâneo.

Redigi ainda dois anexos. Como muitas vezes define-se o período atual do capitalismo comparando-o com a fase anterior, no Anexo 1 encontra-se uma breve caracterização do fordismo inspirada nos conceitos da escola da regulação. No Anexo 2, elaborei uma apresentação de alguns conceitos desenvolvidos por Marx em $O$ Capital que servem de base tanto para Chesnais quanto para Harvey e que são fundamentais para a compreensão do fenômeno da financeirização. Foi realizado também um breve esclarecimento sobre os conceitos empregados pelos diferentes autores tratados na dissertação. 


\section{PARTE I - FRANÇOIS CHESNAIS: REGIME DE ACUMULAÇÃO COM DOMINÂNCIA FINANCEIRA}




\section{CAPÍTULO 1 - O PROCESSO HISTÓRICO-POLÍTICO}

A intenção deste capítulo e do próximo é fazer uma apresentação, a partir de algumas das principais obras de Chesnais, dos pontos fundamentais de sua teoria sobre o regime de acumulação com dominância financeira, conjugando-a com uma análise dessa teorização. Tal apresentação torna-se tanto mais necessária na medida em que, como foi salientado, a obra de Chesnais sobre o assunto encontra-se relativamente dispersa: um livro inteiramente escrito por ele (importante, mas em que a questão das atividades financeiras só é propriamente tratada nos capítulos finais), algumas coletâneas - para as quais ele escreve uma introdução ou capítulo - e vários artigos em revistas.

Ainda que na definição da financeirização normalmente se enfatize uma mudança importante no âmbito da economia - mais precisamente relativa à acumulação do capital -, a dimensão que chamaremos de "histórico-política" é igualmente fundamental e Chesnais insiste nisso ${ }^{31}$. Embora não se possa conceber os dois aspectos em separado (nem temporalmente, nem logicamente), para fins analíticos eles serão tratados em momentos distintos para evidenciar o movimento de mudança.

\footnotetext{
${ }^{31}$ Por exemplo: "O atual regime institucional internacional de dominação do capital resulta do jogo combinado de dois processos que se reforçam mutuamente em um movimento de interação que já dura mais de trinta anos. De um lado houve o reaparecimento e a consolidação de uma forma específica de acumulação do capital (...) De outro, houve, a partir de Margaret Thatcher e de Ronald Reagan, pelos Estados do G-7, a elaboração e a execução de políticas de liberalização, de desregulamentação e de privatização" (itálico nosso) - CHESNAIS, $A$ finança mundializada, p. 20.
} 
A partir do problema posto pela crise de sobreacumulação do capital ${ }^{32}$, é o processo histórico, marcado pela dinâmica política, que ajuda a iluminar as transformações que terão impactos importantes sobre a acumulação e para as quais ele, por sua vez, de certa forma também abre caminho. Tratar-se-á, pois, da acumulação e das características gerais da financeirização somente depois de analisado o processo histórico-político. Tendo conhecido melhor este, compreende-se o surgimento dos novos atores sociais e econômicos e visualizase o novo cenário institucional sob o qual a financeirização vai aos poucos se impondo. Além disso, os fenômenos históricos e políticos normalmente são mais imediatamente percebidos, parecendo ter ocorrido primeiro. Já as mudanças na acumulação se processam nas "profundezas" e por isso necessitam de uma análise mais demorada, às vezes tempos depois de terem se iniciado.

Assim, as mudanças políticas das quais Chesnais trata não por acaso começam nos anos 1970. Elas estão intimamente conectadas com o processo de acumulação do capital, que sofre transformações importantes com o esgotamento do fordismo. A mútua determinação entre os âmbitos político e da acumulação fica mais clara ao se perceber o seguinte movimento: uma crise de sobreacumulação do capital $^{33}$ nos países centrais do capitalismo, em

\footnotetext{
${ }^{32}$ Uma crise de sobreacumulação do capital se origina do estado em que o reinvestimento do capital no mesmo empreendimento/setor produz lucros decrescentes devido aos limites de valorização, ou seja, quando a maisvalia produzida, em quantidade sempre crescente, não pode mais ser reinvestida de forma lucrativa. Esse conceito é fundamental para Harvey, que descreve sua manifestação mais "concreta" do seguinte modo: "uma condição em que podem existir ao mesmo tempo capital ocioso e trabalho ocioso sem nenhum modo aparente de se unirem esses recursos para o atingimento de tarefas socialmente úteis" - HARVEY, Condição pós-moderna, p. 170.

Chesnais, por outro lado, não utiliza propriamente o conceito, mas trabalha com a mesma idéia quando escreve que "a gradativa reconstituição de uma massa de capitais procurando valorizar-se de forma financeira, como capital de empréstimo, só pode ser compreendida levando em conta as crescentes dificuldades de valorização do capital investido na produção" - CHESNAIS, A mundialização financeira, p. 17.

Em Marx, o termo é "Überakkumulation von Kapital", que na edição brasileira aqui citada de $O$ Capital é traduzido como "superacumulação". Em francês e em inglês o termo figura respectivamente como "suraccumulation" e "overaccumulation". Nesse sentido, e visto que os prefixos "sobre" e "super" provêm da mesma raiz latina, "sobreacumulação" e "superacumulação" constituem-se em termos sinônimos. Contudo, utilizar-se-á aqui "sobreacumulação" por ser considerada uma expressão menos ambígua em português: não deixa margem para se pensar em uma acumulação extraordinária, de grande monta (sentido positivo), deixando claro, assim, que se trata de uma acumulação excessiva.

${ }^{33}$ Cabe aqui um pequeno parêntese no intuito de salientar o lugar de destaque que a crise de sobreacumulação dos anos 60/70 ocupa - em relação ao desencadeamento de mudanças fundamentais no capitalismo - para outros autores de relevo, mesmo que estes utilizem outros termos para designá-la. Para Harvey (ver Parte II), haverá a passagem para um regime "flexível" de acumulação e para uma reatualização e um ganho qualitativo de importância do que ele chama de "acumulação por espoliação", o que consolidará uma nova configuração do capitalismo; em Arrighi (Cf. ARRIGHI, $O$ longo século $X X$ ), trata-se de uma virada rumo a um novo período de expansão cíclica das finanças, provavelmente anunciando a crise de hegemonia dos EUA; e para Brenner (Cf. BRENNER, O boom e a bolha: Os Estados Unidos na economia mundial), a crise de sobreacumulação marca o início de um período de estagnação da economia capitalista em escala internacional, que, ao tentar ser resolvida por meio do aumento das atividades financeiras (bolhas), gera crises e turbulências econômicas acentuadas (estouros das bolhas).
} 
curso nos anos 70 (a crise do fordismo), pressiona governos e organismos internacionais a empreenderem ações no sentido de resolver o problema de uma destinação lucrativa para o capital; e a implementação de tais medidas, por sua vez, impactou a dinâmica da acumulação, colocando-a em um novo patamar ${ }^{34}$.

Para Chesnais, a financeirização, ou mundialização financeira ${ }^{35}$, é uma espécie de prolongamento e aprofundamento do fenômeno que ele analisa em seu livro mais célebre e que dá nome a este: a "mundialização do capital”. A princípio, este termo designa, grosso modo, a concentração do capital industrial em escala global, que forma os grandes grupos industriais oligopolistas, e sua atuação estratégica nesses moldes ${ }^{36}$ :

\begin{abstract}
A expressão 'mundialização do capital' é a que corresponde mais exatamente à substância do termo inglês 'globalização', que traduz a capacidade estratégica de todo grande grupo oligopolista voltado para a produção manufatureira ou para as principais atividades de serviços, de adotar, por conta própria, um enfoque e conduta 'globais'. ${ }^{37}$
\end{abstract}

Realmente, sua análise nesse livro se concentra nesses atores, mas logo em seguida ele acrescenta: "O mesmo vale, na esfera financeira, para as chamadas operações de arbitragem"38, de modo que a questão da finança já aparece como um elemento crucial da nova configuração do capitalismo ${ }^{39}$. Chesnais ressalta que esta é diferente não só do fordismo,

${ }^{34}$ Isso fica especialmente evidente em: "A liberalização e a mundialização andaram pari passu, cada avanço de uma reforçando as condições favoráveis a mais um passo da outra. Esse processo é particularmente claro no âmbito financeiro. No entanto, esse movimento conjunto ganhou (...) um caráter de processo incontrolável, com aspectos evidentes de 'fuga para frente' dos governos, cada vez mais impotentes perante as forças que ajudaram a desencadear. Mas esse processo tem conseqüências, sobretudo no tocante à acumulação e ao emprego" - CHESNAIS, A mundializção financeira, pp. 17 e 18 (negritos nossos).

35 O aprofundamento do processo de mundialização do capital - a "mundialização financeira" - acaba por engendrar um "regime de acumulação com dominância financeira", ou simplesmente "regime financeirizado", mas em última instância se confunde com ele.

${ }^{36}$ Desse modo, é importante frisar que a análise de Chesnais se foca prioritariamente nos grandes grupos industriais e da finança, bem como nos países centrais do capitalismo (principais agentes da mundialização). Consequentemente, muitos dos apontamentos feitos pelo autor se referem a esses atores e não diretamente a pequenos empreendimentos ou a países subdesenvolvidos. Contudo, longe de ser uma análise restrita, trata-se do grosso da economia mundial, que se encontra altamente concentrada e oligopolizada.

${ }_{37}^{37}$ CHESNAIS, A mundializção do capital, p. 17.

${ }^{38}$ Ibidem, p. 17.

${ }^{39}$ Chesnais resume em um quadro os "aspectos importantes da mundialização" (Cf. Ibidem, p. 33). Dentre eles pode-se citar: o IED supera o comércio exterior como vetor principal no processo de internacionalização e se torna altamente concentrado; os grupos industriais tendem a se organizar como "empresas-rede"; aumenta a 
mas também do imperialismo clássico - embora tenha muitos aspectos em comum com este, tais como centralização e concentração do capital e interpenetração entre finança e indústria -, pois "o sentido e o conteúdo da acumulação do capital e dos seus resultados são bem diferentes: o capitalismo parece ter triunfado e parece dominar todo o planeta” ${ }^{\natural 0}$. Nesse sentido, é fundamental ter-se em mente que a mundialização impacta igualmente o mercado de trabalho - cujo referencial para as condições de trabalho recentemente passa a ser a China - e as normas de valorização do capital - que tendem a ser mais exigentes, acirrando a concorrência entre os capitalistas em âmbito mundial.

A grande mobilidade dos capitais, sobretudo o financeiro, a liberalização e desregulamentação de mercados, a formação de holdings - empresas estruturadas para priorizar a "liquidez" de seus ativos, ou seja, que se pautam prioritariamente pela lógica financeira - e outros aspectos da mundialização financeira já são apontados nesse primeiro livro de Chesnais, mas só se tornarão o centro da análise e serão aprofundados nas obras subseqüentes ${ }^{41}$. O conceito de "regime de acumulação com dominância financeira" designará então "em uma relação estreita com a mundialização do capital, uma etapa particular do estágio do imperialismo, compreendido como dominação interna e internacional do capital financeiro" ${ }^{42}$.

Retornando, assim, à questão política, o capital financeiro (ou "finança"43) foi alçado ao papel de destaque que possui atualmente por intermédio de um movimento de liberalização e desregulamentação dos sistemas financeiros; e de políticas de centralização dos fundos líquidos de empresas e da poupança das famílias. O processo de mundialização financeira levou anos para se consolidar e foi dividido por Chesnais em três fases, que serão apresentadas a seguir. Seu surgimento relaciona-se a uma situação econômica específica, e

interpenetração dos capitais de diferentes nacionalidades; cresce o número de oligopólios mundiais; há marginalização dos países em desenvolvimento; e, como não podia deixar de ser, ocorre a ascensão de um capital muito concentrado, que conserva a forma monetária, favorecendo a emergência da "globalização financeira" e acentuando a lógica financeira das empresas e os aspectos financeiros dos grandes grupos industriais.

${ }^{40}$ CHESNAIS, A mundializção do capital, p. 14.

${ }^{41}$ Ressalte-se que a versão brasileira é bem mais extensa que a francesa, tendo sido complementada já com elementos do seu livro seguinte.

${ }^{42}$ CHESNAIS, “A 'nova economia': uma conjuntura própria à potência econômica estadunidense”, p. 46.

43 Chesnais esclarece que o termo "finança" é utilizado "para designar simultaneamente as instituições especializadas na centralização do dinheiro 'inativo’ buscando alocação em empréstimos ou em títulos, isto é, os fundos de pensão e de investimento coletivo (ou Mutual Funds), as grandes empresas de seguro e os maiores bancos, e as estruturas institucionais [sendo a principal o mercado de títulos] (...) A finança assim compreendida é a forma assumida pelo ‘capital portador de juro' na fase atual do capitalismo" - CHESNAIS, "La prééminence de la finance au sein du 'capital en général', le capital fictif et le mouvement contemporain de mondialisation du capital", p. 67. 
seu sucesso se deveu a esforços organizados das classes (e países) dominantes, combinado a um contexto histórico-político particular de enfraquecimento das resistências sociais e ideológicas de seus adversários:

O regime financeirizado é uma 'produção' dos países capitalistas avançados, com os Estados Unidos e o Reino Unido à frente. Ele é indissociável das derrotas sofridas pela classe operária ocidental, bem como da restauração capitalista na exUnião Soviética. $^{44}$

Ainda no contexto fordista dos anos 1960 - com sistemas monetários e financeiros compartimentados, uma situação de finanças administradas e internacionalização limitada do capital financeiro -, começa a se formar uma massa de dinheiro "ocioso" derivada em grande parte do lucro das empresas (boa parte delas operando fora dos EUA e evitando repatriar recursos) que não era reinvestido na produção devido à crise de sobreacumulação que já se configurava. Essa massa de dinheiro encontrou refúgio em um mercado offshore de “eurodólares" (existente desde 1958) sediado na City de Londres para onde afluiriam com maior intensidade nos anos 1970, quando o fordismo definitivamente se esgota e a economia mundial entra em recessão. Esse acúmulo marca a primeira etapa da mundialização financeira, ou o prelúdio da constituição do poder da finança: a internacionalização financeira “indireta”. Indireta, pois esse mercado de eurodólares era o único meio de comunicação em larga escala dos capitais monetários de diversos países, uma "fuga" dos sistemas financeiros nacionais compartimentados. Os bancos ainda eram as instituições-chave do mundo financeiro, pois intermediavam diversas operações entre as empresas. O mercado de eurodólares da City era, inclusive, um mercado interbancário.

Adicionalmente, no final dos anos 1960, ataques especulativos contra a libra esterlina e o dólar, moedas fortes e de grande circulação internacional, marcaram o retorno das atividades financeiras especulativas. Por conta da grande regulação, elas tinham ficado latentes durante quase todo o fordismo, mas retornaram com força e colocaram em xeque o sistema de câmbio fixo posto em vigor com os Acordos de Bretton Woods. Estes são definitivamente enterrados em 1971, pela decisão unilateral dos EUA de instituir o câmbio

\footnotetext{
${ }^{44}$ CHESNAIS, “A 'nova economia' (...)”, p. 52.
} 
flexível e eliminar o lastro-ouro de sua moeda ${ }^{45}$. Devido ao enorme peso dos EUA no cenário mundial e ao seu poder de pressão, os demais países acabaram igualmente tendo que adotar o regime de câmbio flexível, o que gerou uma instabilidade cambial crônica que persiste até hoje. Desse modo, o mercado de câmbio teria sido o primeiro elemento a ingressar na mundialização financeira - o seu "abre-alas".

Nos anos 1970, houve ainda um importante fator que impulsionaria as atividades financeiras e seria determinante na subjugação do Terceiro Mundo pelos países centrais: a reciclagem dos chamados "petrodólares". Estes se tornaram superabundantes durante as crises do petróleo, devido à explosão do preço deste, e também precisavam de um destino rentável. Grande parte se dirigiu então aos países subdesenvolvidos sob a forma de empréstimos. Estavam traçados os antecedentes da crise da dívida desses países, que só se consumaria e revelaria suas trágicas conseqüências anos mais tarde, durante a segunda etapa da mundialização financeira.

O "golpe de estado" que instaura de fato a "ditadura dos credores" 46 fica mais nítido, tornando patente a virada política em prol do capital financeiro, com a etapa propriamente de desregulamentação e liberalização financeiras. Ela data das medidas tomadas, entre 1979 e 1981, pelos governos Reagan e Thatcher, nos EUA e na Inglaterra respectivamente, onde, segundo Chesnais, primeiro se reuniram condições políticas e sociais para a afirmação do poder da finança. Tais medidas visaram, inicialmente, à eliminação de uma dupla barreira: entre os diferentes mercados internos, por um lado, e os controles impostos ao movimento de capitais com o exterior, por outro. Houve, assim, uma "abertura" dos sistemas financeiros desses países, tanto interna como para fora ${ }^{47}$, à livre circulação de capitais.

\footnotetext{
${ }^{45}$ Chesnais afirma que isso foi uma medida dos EUA para tentar contornar problemas internos específicos: seu duplo déficit, orçamentário e comercial. - Cf. CHESNAIS, A mundializção financeira, p. 25.

${ }^{46}$ Ambas as expressões entre aspas são empregadas pelo próprio Chesnais: Cf. CHESNAIS, "O capital portador de juros (...)", pp. 39 e 40.

47 "O termo 'abertura' designa dois processos: aquele relativo às barreiras internas, anteriormente estanques, entre diferentes especializações bancárias ou financeiras, e aquele relativo às barreiras que separam mercados nacionais dos mercados externos. Abertura significa ainda o fim dos segmentos e especializações anteriores. Com efeito, trata-se de processos indissolúveis”- CHESNAIS, A mundialização do capital, p. 264.
} 
O movimento de desregulamentação monetária e financeira que se seguiu levou, primeiramente, à "quase completa perda de controle pelos bancos centrais (...) sobre a determinação das taxas de juros" ${ }^{\sharp 8}$, ao menos as de médio e longo prazos, que ficaram sob controle dos operadores financeiros mais poderosos. Além disso, elas significaram também "a abolição das regulamentações e controles no tocante à fixação dos preços dos serviços bancários"49, o que levou ao surgimento de inúmeros novos produtos financeiros. Contudo, uma de suas consequiências fundamentais mais imediatas foi promover a expansão dos mercados de títulos de dívida e a sua interligação em âmbito mundial ${ }^{50}$.

A liberalização dos mercados de negociação de papéis da dívida dos Estados foi de importância primordial para a ascensão da financeirização, na medida em que a "securitização"51 da dívida expandiu o escopo do capital fictício. Esses mercados vieram responder às necessidades e interesses de dois atores de peso. De um lado, dos próprios governos, que buscavam formas alternativas de financiar seus déficits e puderam fazê-lo precisamente securitizando suas dívidas. De outro, dos grandes grupos centralizadores de poupança, que - exatamente por terem chegado naquele momento a uma alta concentração de capital monetário - precisavam valorizar o capital sob seu controle e encontraram esse enorme volume de títulos de dívidas a juros elevados. Todavia, essa "complementaridade" era profundamente assimétrica, subordinando os Estados aos seus credores:

\begin{abstract}
A ‘mercadorização' dos títulos públicos marcou a entrada da economia mundial na era das taxas de juros reais positivas. Ela pôs nas mãos dos investidores financeiros a capacidade de determinar o nível de 'remuneração' dos empréstimos, isto é, das taxas de juros a longo prazo. ${ }^{52}$
\end{abstract}

Embora Chesnais não detalhe os mecanismos pelos quais esse controle dos juros pelos próprios credores ocorre ${ }^{53}$, fica clara a posição privilegiada destes. Conseguiram dar um destino rentável a seu capital, e ainda influenciar a taxa de valorização do mesmo. Na

\footnotetext{
${ }^{48}$ CHESNAIS, A mundializção do capital, p. 261.

${ }^{49}$ CHESNAIS, A mundializção financeira, p. 262.

${ }^{50}$ Essas medidas se inserem no conjunto de princípios e práticas políticos que seus críticos convencionaram denominar genericamente de "neoliberalismo".

${ }^{51}$ Termo que vem do inglês "securitization", e significa a transformação de dívidas contratuais em títulos negociáveis nos mercados secundários. Ao se diluir a dívida em diversas mãos, os riscos de inadimplência diminuem. Trata-se, pois, de um termo carregado ideologicamente, já que a "segurança" é para o credor.

Além disso, o amplo recurso à securitização (não só da dívida pública) reforçou muito o processo de financeirização, ao transpor para os mercados financeiros transações que antes eram feitas diretamente entre as partes.

52 Ibidem, p. 26.

${ }^{53}$ Embora no Brasil, e em muitos outros países, não haja grande mistério: os representantes do capital financeiro ocupam posições-chave do Banco Central (vide, por exemplo, Henrique Meirelles).
} 
realidade, foi uma dupla vitória das rendas elevadas, ao se combinarem os empréstimos a taxas elevadas e a redução de impostos sobre o capital e sobre as rendas das classes superior e média - possível graças à facilidade de captação de recursos oferecida pela securitização (na medida em que a liquidez dos títulos amplia o crédito do governo). A tudo isso ainda se soma a impunidade na prática de evasão de divisas rumo a paraísos fiscais.

Tais medidas, por conseguinte, retroalimentam a necessidade dos governos de tomar mais dinheiro emprestado devido à perda de receita e ao alto serviço da dívida. De modo que, segundo Chesnais, "a escolha do endividamento no lugar dos impostos como modo de financiamento das despesas públicas tem com certeza profundas raízes sociais" ${ }^{\Perp 54}$ e funcionou como um dos principais - senão o principal - fator de subordinação do Estado aos interesses da finança.

A manipulação da taxa de câmbio era, adicionalmente, um meio de potencializar o mecanismo dos juros altos. Os EUA a utilizaram largamente para atrair a liquidez mundial, o que fez sua dívida pública multiplicar-se durante a década de $80^{55}$. Ficou evidente, assim, seu papel na implementação da ditadura dos credores em âmbito mundial, dado o valor absoluto astronômico de sua dívida. Dessa forma, o mercado de títulos públicos tornou-se central e veio se somar ao mercado de câmbio como pilar da mundialização financeira.

A expressiva alta do dólar e das taxas de juros americanas em um curto espaço de tempo (de 2-3\% a 10-12\% em alguns meses, segundo dados de Chesnais) completa, portanto, as principais medidas do governo Reagan que instauraram mundialmente o "golpe de Estado" dos credores, "resultando numa capacidade de modificar a repartição de renda e de influenciar o ritmo e a orientação do investimento em todos os países em que o setor público é importante" 56 . Os países do Terceiro Mundo viram suas dívidas, grande parte das quais originada da reciclagem dos petrodólares mencionada anteriormente, serem multiplicadas do dia para a noite, já que eram denominadas em dólar e atreladas às taxas de juros dos EUA (não tinham taxa pré-fixada). As negociações ocorridas durante os anos 80 tiveram por efeito torná-las impagáveis. Ao ultrapassar certo montante, a dívida desses países periféricos se tornou "um mecanismo de transferência de recursos que possui a capacidade de se reproduzir no tempo" ${ }^{\text {, }}$, perpetuando seu estado de subordinação. É o chamado efeito "bola-de-neve",

\footnotetext{
${ }^{54}$ CHESNAIS, A finança mundializada, p. 24.

${ }^{55}$ Cf. CHESNAIS, A mundializção financeira, pp. 26 e 27. Ver também dados fornecidos na Introdução.

${ }^{56}$ CHESNAIS, “A 'nova economia' (...)”, p. 48.

${ }^{57}$ CHESNAIS, “O capital portador de juros (...)”, p. 39.
} 
que foi particularmente injusto com os países periféricos - devido às taxas de juros consideravelmente superiores às taxas de crescimento, e aos empréstimos sucessivos que tiveram que ser tomados para honrar o serviço da dívida -, mas que acaba atingindo até mesmo os países centrais ${ }^{58}$.

Nesses países, mesmo se a taxa de juros não estiver muito acima do nível de crescimento da produção e do PIB, a dívida pode aumentar muito depressa. A diferença é a maior capacidade que eles têm (em relação aos periféricos) de rolar suas dívidas, o que ainda assim não os livra da dominação do capital financeiro. Aliás, ao contrário: segundo Chesnais, foi precisamente nos países centrais que a dívida pública atingiu tal magnitude ${ }^{59}$ que permitiu ao capital portador de juros um crescimento não só quantitativo, mas também qualitativo. Enfim, Chesnais é categórico: "nos países da OCDE, como nos países periféricos, a dívida pública alimenta continuamente a acumulação financeira por intermédio das finanças públicas"60.

Por fim, a dívida pública tem ainda outras implicações políticas em função da importante propriedade de: gerar, para seu pagamento, pressões fiscais intensas sobre as rendas mais baixas (tributação regressiva, por exemplo); implementar e justificar a austeridade orçamentária (sobretudo cortando-se gastos sociais, considerados “improdutivos"); e, em decorrência disso, paralisar as despesas públicas. Isso facilitou, por exemplo, as privatizações em diversos países, resultando em uma "desresponsabilização" do Estado sobre algumas áreas e na abertura de novos canais de investimento para o capital sobreacumulado ${ }^{61}$.

A partir do "Big Bang" da City ${ }^{62}$, em 1986, ingressou-se na terceira fase da mundialização financeira apontada por Chesnais. Após a inclusão dos mercados de câmbio e

\footnotetext{
58 A partir de 1984-85 os demais países do G7 passaram a adotar a nova "moda" de se financiar via securitização.

${ }^{59}$ Foi aí, e não no Terceiro Mundo, que, em termos absolutos, ela foi decisiva para o poder da finança. As suas conseqüências sociais - em termos de pobreza, exclusão, etc. - é que são mais agudas e patentes na periferia.

${ }^{60}$ CHESNAIS, "O capital portador de juros (...)", p. 41.

61 “A 'dívida do Terceiro Mundo’ foi uma alavanca poderosa que permitiu impor as políticas energéticas e de ajuste estrutural, austeridade fiscal, liberalização e privatização" - Ibidem, p. 67.

${ }^{62}$ Conjunto de medidas liberalizantes colocadas em prática num curto espaço de tempo na praça financeira londrina, que acabou pressionando os mercados de outros países a também realizarem mudanças nesse sentido.
} 
de títulos da dívida - que continuaram crescendo e abrigando cada vez mais transações -, foi a vez dos mercados acionários serem abertos e desregulamentados em todo o mundo. Aos poucos, os dividendos se tornaram um mecanismo vital de transferência de riqueza e de acumulação de capital, o que elevou o mercado de ações à posição de "pivô mais ativo"63 da acumulação financeira $^{64}$. Tem-se então uma generalização da arbitragem, em que os capitais buscam as melhores oportunidades de valorização em diferentes mercados de diversos países, acirrando a concorrência entre eles.

Além disso, o uso político das taxas de juros fica novamente em evidência com a virada ocorrida. Na fase anterior, viu-se que os EUA forneceram os alicerces do poder da finança e o consolidaram por meio de elevadas taxas de juros, ao criarem uma enorme dívida pública com efeito bola-de-neve. Posteriormente, eles se utilizaram de uma política de juros muito baixos, até negativos, para incentivar a aplicação de capitais nos mercados acionários (já que os títulos da dívida se tornam menos interessantes nesse cenário) e mantê-los permanentemente "oxigenados". Parece haver, assim, uma espécie de "divisão de tarefas": os mercados acionários, e de câmbio (que são também enormes e muito líquidos), oferecem rendimentos mais elevados, ao passo que os títulos de dívida pública oferecem mais segurança e são procurados sobretudo em períodos de crises e turbulências financeiras.

As mudanças levadas a cabo por governos nacionais e organismos internacionais que remodelam o cenário mundial são complementadas pela expressão do poder da finança no interior das empresas: a "governança corporativa"65, um padrão organizacional que visa atrelar as empresas à lógica financeira. Trata-se não só de um mero conjunto de regras e

${ }^{63}$ CHESNAIS, “O capital portador de juros (...)”, p. 42.

${ }^{64}$ Sem contar a multiplicação de "produtos financeiros", que potencializaram os mercados de derivativos.

${ }^{65}$ Do termo em inglês corporate governance. Os professores Rosa Marques e Paulo Nakatani, tradutores de $A$ finança mundializada, inserem a seguinte nota no texto de Chesnais: "O governo das empresas (ou sociedades) foi sistematizado pela OCDE na forma de um conjunto de princípios que deveriam ser seguidos pelas empresas, para dar maior estabilidade ao sistema financeiro, cujo ponto central decorre da separação entre a propriedade e o controle e da relação entre acionistas e administradores das empresas" - Ibidem, p. 42, nota dos tradutores. Mais detalhes podem ser obtidos no documento OCDE, Princípios da OCDE sobre o governo das sociedades, no qual se encontram pérolas como:

"Os decisores políticos estão agora mais cientes do contributo que o bom governo das sociedades dá à estabilidade dos mercados financeiros, ao investimento e ao crescimento económico. As empresas compreendem melhor a forma como o bom governo das sociedades contribui para a sua competitividade. Os investidores, especialmente as instituições de investimento colectivo e os fundos de pensões agindo na qualidade de entidades fiduciárias, apercebem-se de que têm um papel a desempenhar na garantia da adopção de boas práticas de governo das sociedades, justificando deste modo o valor dos seus investimentos. Nas economias da actualidade, o interesse no governo das sociedades ultrapassa o mero interesse dos accionistas no desempenho individual das empresas. Uma vez que as empresas desempenham um papel central nas nossas economias e dependemos cada vez mais de instituições do sector privado para gerir as poupanças pessoais e assegurar rendimentos para a reforma, o bom governo das sociedades afigura-se importante para um número cada vez maior e mais diversificado de camadas da população" (p. 3). 
princípios criados para a administração mais eficiente e segura de grandes sociedades anônimas, mas de uma técnica de subordinação (e cooptação ${ }^{66}$ ) dos administradores ${ }^{67}$ aos interesses dos acionistas e às normas de rentabilidade exigidas por estes. A elevação dessas exigências reverte-se em pressões sobre os trabalhadores, em termos de rebaixamento de salários, flexibilização dos contratos e da organização do trabalho, pressão por produtividade, etc. ${ }^{68}$ :

A flexibilização salarial é também um elemento central constitutivo da alta taxa de exploração, referente àquilo que as empresas devem extrair e/ou centralizar como massa de mais-valia (...) a fim de que as normas de rentabilidade possam ser satisfeitas. ${ }^{69}$

Um outro elemento que caracteriza e coroa essa etapa da mundialização financeira é a incorporação dos mercados "emergentes" ao longo dos anos 90. Premidos por seu endividamento e pela desregulamentação dos demais países, eles foram obrigados, sob forte pressão dos EUA e do FMI, a entrar no jogo da mundialização financeira. Trata-se tanto de mercados recém constituídos - certos países da Ásia, por exemplo - como mercados mais antigos que se encontravam consideravelmente fechados ao exterior - como na Argentina - e se abrem ao capital externo. A entrada desses mercados bem mais frágeis, no quadro de uma integração "imperfeita", acirra a assimetria de condições dos participantes desse sistema mundializado, o que leva a uma série de choques e sobressaltos financeiros que se tornaram constantes.

A lista desses fenômenos financeiros é extensa ${ }^{71}$. Vai-se desde o crash das bolsas em 1987, que atinge Nova York, e do estouro da bolha dos créditos podres dois anos depois, passando pela falência de bancos e instituições financeiras em vários países, até às crises em mercados emergentes, como a do México (1994-95) - que já havia colapsado em 1982, numa

\footnotetext{
${ }^{66}$ Cooptação, pois um dos elementos da corporate governance é tentar aproximar o administrador dos interesses dos acionistas, por exemplo, pagando-lhe em opções de compra de ações da própria empresa, as stock options, o que o torna, de certa forma, acionista da empresa ou ao menos mais interessado na cotação das ações e na distribuição de dividendos.

${ }^{67}$ Para não haver confusão, o termo "administrador" será reservado para os dirigentes das empresas (o correspondente da palavra manager do inglês, e empregada também em francês) e o termo "gestor" para os gestores/administradores de fundos e instituições financeiras.

${ }^{68}$ Para uma análise que condensa as transformações no modelo empresarial, articulando-as ao novo cenário de financeirização e neoliberalismo, ver BRAGA, "Dilemas do desenvolvimento: A empresa neoliberal e a hegemonia financeira".

${ }^{69}$ CHESNAIS, “A 'nova economia' (...)”, p. 51.

${ }^{70}$ Cf. CHESNAIS, A mundialização financeira, p. 12. "Imperfeita”, pois os países não se inserem todos da mesma forma na mundialização financeira.

${ }^{71}$ Alguns episódios são analisados por Chesnais no último capítulo de A mundialização financeira.
} 
primeira manifestação da crise da dívida - e os de países asiáticos em 1997. Acrescentam-se, mais recentemente, o estouro da Nasdaq em 2000-2001 e a devastadora crise mundial de $2008^{72}$, para ficar nos casos mais emblemáticos.

A análise de Chesnais mostra que as sucessivas fases de implementação da mundialização financeira colocaram em cena novos atores e reposicionaram aqueles já existentes, obrigando-os muitas vezes a se adaptarem às novas condições. Trata-se tanto de agentes institucionais no âmbito mundial, como de funções desempenhadas na estrutura das empresas que se modificaram, por exemplo, com a governança corporativa. Embora os grupos industriais transnacionais ainda sejam a faceta mais visível e mais facilmente identificável do capitalismo contemporâneo - por representar de forma direta a dominação social e política do capital frente aos trabalhadores -, as instituições financeiras (bancárias e não-bancárias) são cruciais. Uma análise das transformações ocorridas é importante para o entendimento da dimensão política da financeirização e para uma compreensão mais concreta do que significa o poder da finança ou o domínio do capital financeiro.

No início do século XX, Rudolf Hilferding ${ }^{73}$ já havia descrito e analisado o papel proeminente dos bancos no capitalismo e sua participação ativa nos rumos da produção. Tal situação não se alterou fundamentalmente durante a vigência do fordismo, de modo que, na primeira etapa da mundialização financeira, quando o poder da finança apenas se prenunciava, os bancos continuavam os intermediários centrais entre o capital monetário em busca de investimento e aqueles que buscavam crédito, ou seja, entre a centralização monetária e a sua aplicação. A partir da segunda etapa, como parte da instauração da "ditadura dos credores”, outras instituições financeiras ganharam relevância e acabaram por tomar dos bancos sua posição privilegiada devido a políticas que promoveram a centralização da poupança das famílias e de lucros das empresas em suas mãos.

Com a liberalização e crescimento dos mercados acionários e de bônus, governos e empresas puderam - mediante emissões de ações ou de títulos de dívida, por exemplo - captar

\footnotetext{
${ }^{72}$ Para uma análise das origens dessa crise, ver CHESNAIS, "Fin d'un cycle. Sur la portée et le cheminement de la crise financière".

${ }^{73} \mathrm{C}$. HILFERDING, O capital financeiro.
} 
dinheiro sem a intermediação dos bancos e de instituições tradicionais. A isso se chamou de processo de "desintermediação financeira", uma vez que os mercados financeiros propiciam uma operação mais direta entre provedores e tomadores de dinheiro, possibilitando ganhos com os diferenciais de juros ${ }^{74}$. Em decorrência desse processo, organizações não-bancárias já existentes ou recentemente criadas se fortaleceram. Entre as principais, podem-se citar as seguradoras, os fundos de pensão, e os fundos mútuos e de $h e d g e^{75}$ - todas instituições que centralizam um enorme volume de dinheiro em busca de valorização financeira. Eles foram aqueles que mais ganharam com os déficits dos países da OCDE, com as altas taxas de juros e com as medidas de liberalização e desregulamentação postas em prática. Uma "imensa transferência de riqueza em favor desses investidores institucionais não bancários",76 ocorreu, da qual todos os possuidores de títulos também se beneficiaram.

Dados fornecidos por Chesnais sobre a OCDE mostram a capacidade de concentração de capital desses investidores institucionais e a importância que eles adquirem no cenário econômico mundial:

No fim dos anos 90, o volume de ativos em posse do conjunto dos investidores institucionais ultrapassava US\$ 36 trilhões. Esses haveres representavam em torno de $140 \%$ do PIB dos países da zona da OCDE (...) Ao longo da década, o crescimento do valor dos ativos dos investidores institucionais se fez a um ritmo sustentado, mais de $11 \%$ em média durante o período. ${ }^{77}$

Como não poderia deixar de ser, o poder "material" desses investidores é acompanhado de sua dimensão "ideológica", legitimadora. Isso fica particularmente claro a respeito dos fundos de pensão por capitalização (aposentadoria privada), devido à sua dupla natureza. Por um lado, são constituídos de contribuições originadas dos salários e outras remunerações advindas do trabalho. Nesse sentido, sua origem está fundamentalmente na poupança, às vezes de uma vida inteira, dos trabalhadores. Contudo, ao centralizar esse

\footnotetext{
${ }^{74}$ Mas "a desintermediação diz respeito também aos mercados de poupança ou fundos de reserva de particulares que gozam de bons rendimentos. Devido aos mesmos diferenciais de taxas de juros, os clientes começaram a transferir seus fundos das contas de poupança, ou mesmo de sua apólice de seguro, para fundos que oferecem maior rentabilidade" - CHESNAIS, A mundializção do capital, p. 263.

${ }^{75}$ Não é necessário entrar em tecnicidades. Basta ter em mente que fundos mútuos e fundos de hedge, embora tenham, em alguns países, certas especificidades em termos de regras e normas a cumprir que os distingam um do outro, são centralizadores de dinheiro de pessoas físicas ou jurídicas sob a administração de um ou mais gestores financeiros. Esses fundos possuem diversos perfis de risco, mas normalmente são bastante "arrojados", para ficar no jargão, e aplicam em diversos tipos de papel (inclusive os fundos de hedge, a despeito de o significado do termo ser "proteção").

Segundo Wolf, estima-se que o número de fundos de hedge tenha passado de 610, em 1990, a 9.575 em 2007 Cf. WOLF, "Novo capitalismo financeiro provoca revolução global".

${ }^{76}$ CHESNAIS, "La prééminence de la finance (...)", p. 104.

${ }^{77}$ CHESNAIS, "O capital portador de juros (...)”, pp. 43 e 44.
} 
montante enorme de dinheiro e ao inseri-lo nos mercados financeiros para ser valorizado, esses fundos se tornam, por outro lado, um tipo de investidor institucional. Nas mãos dos gestores dos fundos, o valor originado do trabalho transmuta-se em capital monetário a fim de gerar uma renda futura para seu proprietário, conservando sua liquidez e buscando rentabilidade máxima. Isso tem um impacto importante no lugar social ocupado por muitos trabalhadores:

Os assalariados aposentados deixam de ser 'poupadores' e tornam-se, sem que tenham clara consciência disso, partes interessadas das instituições cujo funcionamento repousa na centralização de rendimentos fundados na exploração dos assalariados ativos, tanto nos países onde se criaram os sistemas de pensão por capitalização quanto naqueles onde se realizam as aplicações e as especulações. Os planos de poupança salarial fazem de seus beneficiários indivíduos fragmentados, cuja personalidade social está cindida: de um lado, a de assalariados e, de outro, de membros auxiliares das camadas rentistas da burguesia. ${ }^{78}$

O segredo dessa "transmutação" reside em algo que Marx já ressaltava, a saber, a centralização de pequenas somas que, isoladamente, não poderiam ser postas para se valorizar. Ou seja, trata-se de uma mudança qualitativa do caráter daquele dinheiro ${ }^{79}$ possibilitada pela sua reunião e por seu aumento quantitativo ultrapassar certo limiar. Não se deve esquecer que esses fundos muitas vezes nasceram por iniciativa das próprias empresas e eram compulsórios. Assim, eles se tornaram atores poderosos e muito atuantes nas especulações e atividades dos mercados financeiros em favor das grandes fortunas, mas gozando de certo modo de uma justificativa ideológica. É difícil fazer uma crítica radical dos fundos de pensão quando aparentemente seu objetivo, inclusive declarado, é proporcionar uma renda aos trabalhadores aposentados a partir de suas próprias economias. Nesse sentido:

De maneira contraditória, as mudanças nas relações de força com uma repartição da riqueza em benefício das camadas sociais mais ricas se apoiaram em medidas que foram apresentadas como feitas em favor dos assalariados enquanto futuros aposentados. $^{80}$

\footnotetext{
${ }^{78}$ CHESNAIS, “O capital portador de juros (...)”, pp. 51 e 52.

${ }^{79}$ Harvey argumenta que mesmo os simples "poupadores", ao depositarem seu dinheiro nos bancos ou outras instituições centralizadoras de fundos, já perdem sua "identidade social": "a poupança de todas as classes pode ser mobilizada como capital monetário. A consequiência, contudo, é que capitalistas, rentistas, senhores de terra, governos, trabalhadores, administradores de empresa, etc. perdem sua identidade social e se tornam poupadores" - HARVEY, Limits to Capital, p. 262.

${ }^{80}$ CHESNAIS, "La prééminence de la finance (...)", p. 103.
} 
A grande acumulação financeira alcançada pelos investidores institucionais é ao mesmo tempo causa e conseqüência de sua existência e de sua atividade: por um lado, a liberalização e desregulamentação das atividades financeiras lhes permitiu atuar em escala global - ampliando suas oportunidades de investimento e de diversificar suas fontes de captação de recursos - e, portanto, adquirir o tamanho e a importância que possuem hoje; por outro lado, os recursos já centralizados por eles conferem-lhes maior capacidade de obter novos recursos - por exemplo, assumindo o controle de empresas e impondo elevadas normas de rentabilidade das ações ${ }^{81}$. Por meio das transações em Bolsas, esses investidores institucionais conseguiram se tornar proprietários, ou acionistas majoritários, dos grandes grupos industriais. $\mathrm{O}$ controle exercido por esse tipo de agente vai sempre no sentido de impor a busca da maximização do valor das ações da empresa e do pagamento de dividendos. Esse foi um dos modos pelos quais os investidores institucionais passaram a ter sob sua administração não só a "poupança das famílias", mas também partes crescentes dos lucros (não reinvestidos) das empresas.

No âmbito das empresas, esse processo tem conseqüências importantes, sobretudo em termos sociológicos. Segundo Chesnais, o período de aproximadamente cinquenta anos entre a Crise de 29 e o restabelecimento do poder da finança testemunhou a dominância ou autonomia relativa do administrador de empresa frente aos acionistas-proprietários. Isso se dava principalmente pelo grande número destes e pelo seu conseqüente alto grau de dispersão ${ }^{82}$.

Eis uma característica contraditória das Bolsas: se, de um lado, ela permite grande desenvolvimento das sociedades anônimas ao abrir caminho para o aumento da quantidade de acionistas (que hoje se elevam formalmente às dezenas de milhões nos países centrais), de outro lado, ela é um mecanismo impessoal e dispersivo, dificultando, assim, a articulação entre os acionistas de uma mesma empresa. Isso é tanto mais verdade quando se trata dos acionistas de pequeno porte ou dos detentores de ações preferenciais (que não têm nem mesmo direito a assento no conselho da empresa e pouco podem fazer pelos seus interesses).

\footnotetext{
${ }^{81}$ Lordon fala de uma meta arbitrária, já que baseada em critérios de rentabilidade puramente financeira, de $15 \%$ de "ROE, Return on Equity" comumente praticada - Cf. LORDON, Fonds de pension, piège à cons? Mirage de la démocratie actionnariale, p. 39. Ver também CHESNAIS, "La prééminence de la finance (...)”, p. 109.

${ }^{82}$ Cf. CHESNAIS, "La prééminence de la finance (...)", p. 106.
} 
Em um cenário como esse, o administrador gozava de relativa liberdade de decisão e ação, pois havia meios mais restritos de os acionistas controlarem sua atividade.

Essa situação só foi superada a partir das mudanças introduzidas pela governança corporativa e pela mencionada centralização dos fundos de pensão ${ }^{83} /$ de investimento e de sua compra massiva de ações ${ }^{84}$. Eles passaram, então, a agir como blocos de poder, substituindo a dispersão dos acionistas pelo comando concentrado de instituições e empreendendo fusões e aquisições em grande escala. Esse é um dos marcos da "restauração do poder da finança" em novos patamares e se traduz no seguinte comentário de Chesnais:

É possível que isso seja um dos traços mais originais da contra-revolução social contemporânea. A partir dos anos 80, os proprietários-acionistas despenderam energia e meios jurídicos, ou quase jurídicos, consideráveis para subordinar os administradores-industriais e os transformar em gente que interiorizasse as prioridades e os códigos de conduta nascidos do poder do mercado bursátil. ${ }^{86}$

Evidentemente, esse processo não se deu sem problemas. A implementação da governança corporativa envolveu interesses divergentes: de um lado, dos acionistas - que se pautam pela valorização das ações e pelos dividendos que podem ser extraídos destas - e, de outro, dos administradores - preocupados, por exemplo, com os rumos efetivos da empresa, com o incremento da produção e de seus salários e até com sua imagem de "bom administrador" ${ }^{\prime 87}$. No final do processo, a finança triunfou, de um modo bastante peculiar, por um percurso sinuoso e ambíguo. Após aproximadamente uma década de adaptação, a figura do "administrador-industrial" foi transformada em um novo personagem - o "administrador-

83 Klagsbrunn ressalta que os fundos de pensão muitas vezes possuem uma lógica de valorização mais conservadora e voltada para o longo prazo, havendo inclusive aplicação em imóveis (em detrimento da liquidez e com transformação do capital portador de juros em renda fundiária) - Cf. KLAGSBRUNN, "Mundialização x Globalização e o papel das Finanças no capitalismo contemporâneo". Embora isso possa ser verdade (ele não fornece nenhum dado quantitativo ou referência, além de não considerar que possa haver variações de país para país), há certos aspectos a se considerar. Primeiramente, o próprio autor afirma que "boa parte dos fundos de pensão passou a gestão de seus recursos para fundos mútuos, para bancos e para companhias de seguros" (p. 23) que reconhecidamente não possuem um perfil conservador de administração. Em segundo lugar, a atuação "conservadora" dos fundos de pensão não se dá devido à sua lógica de operação, mas a despeito dela (através da coerção jurídica). Em terceiro lugar, quanto à aplicação em imóveis, é importante salientar que provavelmente isso não é feito em qualquer tipo de imóvel, nem em qualquer conjuntura. Além disso, não necessariamente desaparece o caráter especulativo de sua prática (ao contrário, a especulação imobiliária pode atingir níveis altíssimos) e o que se observa é, de todo modo, uma lógica rentista em operação, sob diferentes formas.

84 'Nos Estados Unidos, um limiar na transferência de 'propriedade' para os investidores institucionais foi ultrapassado mais ou menos em 1985. Em 1990, sua participação nas ações na Bolsa de New York, New York Stock Exchange (NYSE), atingiu 40\%, enquanto era somente de 3\% em 1950" - CHESNAIS, "La prééminence de la finance (...)", p. 106.

${ }^{85}$ CHESNAIS, “O capital portador de juros (...)", p. 53.

${ }^{86}$ Ibidem, p. 54.

87 Não se pode esquecer que os administradores são "funcionários" das empresas, existindo, portanto, um "mercado de trabalho" para eles. 
financeiro" ${ }^{\text {} 88}$. Segundo Chesnais, ao se inteirarem dos segredos dos mercados e serviços financeiros, esses novos administradores aprenderam a usá-los a seu favor. Contudo, ao mesmo tempo em que se livravam de certos controles, eles interiorizaram progressivamente as normas e objetivos do mundo da finança ${ }^{89}$ :

Ele [o administrador-financeiro] contornou rapidamente o controle do qual era, a princípio, objeto. Mas suas prioridades são muito diferentes das do administradorindustrial que ele substituiu. Os grupos são dirigidos por pessoas para as quais a tendência da Bolsa é mais importante do que qualquer outra coisa. O controle da corporate governance foi em geral frustrado, mas os valores da finança triunfaram. $^{90}$

Às duas categorias de "servidores do capital", a do gestor financeiro - representante dos acionistas dispersos (capital monetário / propriedade do capital produtivo) - e a do administrador - que, apesar de sua cooptação pelos interesses da finança e de não ser capitalista propriamente dito, ainda encarna algo do capitalista produtivo, por dirigir o trabalho -, soma-se um outro tipo, para complicar os conflitos existentes: os analistas financeiros e os bancos de investimento. São eles os responsáveis pela elaboração de normas e procedimentos que orientam a ação de administradores e gestores e que medeiam a relação entre ambos. Todavia, tais normas, procedimentos e mesmo critérios de rentabilidade são apresentados não como fruto de interesses e avaliações da finança, mas sob a autoridade impessoal e indiscutível do mercado. A cotação das ações e o rendimento do portfólio de investimentos financeiros são os critérios fundamentais da análise do desempenho, o que coloca os gestores numa situação de concorrência extremada entre si. Esse tipo de competição leva-os a assumirem riscos cada vez maiores, constituindo-se em um dos fatores principais de crises e instabilidades e gerando bolhas e capital fictício em grande escala. A grande crise de 2008 é uma excelente demonstração disso.

Nesse sentido, Chesnais parece estar correto ao estabelecer certa diferença entre a análise de Hilferding sobre o capital financeiro e a situação atual ${ }^{91}$. Para este, havia uma aliança estreita, por vínculos bastante fortes, entre os grandes industriais e os banqueiros. Atualmente, essa associação parece ter sido substituída por uma relação mais complicada,

\footnotetext{
${ }^{88}$ Os dois termos entre aspas são de Chesnais (ver referência na próxima nota).

89 Embora Chesnais mencione os "valores" da finança, há razões bem mais objetivas também operando. O administrador se pauta pela cotação da Bolsa, pois, em um ambiente financeirizado, parte de sua remuneração (stock options) e mesmo sua permanência no emprego dependem desse fator, assim como, a capacidade de financiamento da empresa.

${ }^{90}$ CHESNAIS, "O capital portador de juros (...)", p. 54.

${ }^{91}$ Cf. CHESNAIS, "La prééminence de la finance (...)", item 3.
} 
talvez até mais conflituosa, entre administradores de grupos industriais e gestores de fundos, mediada por analistas financeiros e bancos de investimento. Nesse emaranhado, independentemente de quem leva vantagem em tal ou qual conjuntura, a finança como um todo triunfou e são os trabalhadores as grandes vítimas, ao sofrerem as consequiências da imposição de elevadas taxas de rentabilidade às empresas - algo consensual entre esses "servidores do capital".

Em $O$ Capital, Marx pressupunha a ação do Estado, sem, contudo, desenvolver a análise de sua participação na vida econômica e na expansão do capital portador de juros. O conjunto da obra de Chesnais, por outro lado, deixa transparecer uma dimensão muito clara do processo político de constituição do regime financeirizado, a saber, o das políticas governamentais, tais como as medidas tomadas nos governos Reagan e Thatcher. Apesar da mundialização, os Estados nacionais continuam existindo e atuando, porém de forma hierarquizada ${ }^{92}$. A ação das instituições políticas de Estados nacionais e de organismos internacionais é evidente no processo de liberalização e desregulamentação financeiras, no sentido de fortalecer e interconectar os mercados financeiros, restituindo-lhes a liquidez, etc., o que indica uma vitória política da finança.

Contudo, ao se raciocinar de forma mais "sociológica" sobre a primazia do capital financeiro sobre o capital industrial, o significado desse resultado já não é tão claro. A imposição de certa lógica geral de valorização do capital sobre outra tem que tipo de impacto sobre as frações internas da burguesia? Haveria uma disputa política real entre uma "burguesia financeira" e uma "burguesia industrial", na qual esta sai, ainda que relativamente, derrotada? Uma tal conformação seria análoga ao modo como Marx constrói sua análise sobre os embates políticos na França ${ }^{93}$. Financistas e industriais possuem interesses imediatos divergentes, por vezes diretamente conflitantes, apesar de, como burgueses, compactuarem na manutenção da ordem capitalista.

Por outro lado, Chesnais sugere um processo de enfraquecimento das fronteiras entre setor financeiro e indústria, característico do regime financeirizado. Os grandes grupos

\footnotetext{
${ }^{92}$ Donde a atualidade do tema do imperialismo e a importância de se retomarem teóricos como Hilferding.

${ }^{93}$ Conforme apontado na Introdução.
} 
industriais, especialmente na forma de holdings $s^{94}$, operam a partir da lógica financeira e estão profundamente comprometidos com o funcionamento dos mercados financeiros ${ }^{95}$. Donde a questão cuja resposta não está inteiramente clara nos textos de Chesnais: a "vitória", o "golpe de Estado" da finança se dá sobre quem? Quem é o "derrotado"? O proletariado, decerto, mas também partes da burguesia? Ou seja, trata-se também de uma virada na correlação de forças interna à burguesia, ou de um processo que dá uma nova conformação à burguesia como um todo, ao comprometê-la com os destinos do mercado financeiro?

Uma resposta a essa questão demandaria uma análise aprofundada que não é possível neste trabalho. Ficam, portanto duas indicações de aspectos importantes a serem considerados. Primeiro, até que ponto a burguesia industrial se comprometeu com o funcionamento dos mercados financeiros e se adaptou à nova ordem (conservando seu poder), ou foi submetida pelos ditames da finança (sofrendo realmente uma derrota) ${ }^{96}$. Segundo, averiguar se a dissolução das barreiras entre as lógicas produtiva e financeira não dizem respeito somente aos grandes grupos industriais transnacionais, de modo que se deve considerar não só a clivagem burguesia financeira/industrial, mas também a de estratos superiores/inferiores da burguesia. Desse modo, poder-se-ia cogitar a hipótese de que a camada superior da burguesia industrial consegue de algum modo conservar seu poder ao se transformar, ao passo que as camadas mais baixas são efetivamente submetidas.

Não obstante, a consideração do processo político de instauração da financeirização é igualmente importante sob outros aspectos. Um deles, diversas vezes ressaltado por Chesnais, é dar destaque ao caráter histórico do fenômeno, o que, de um lado, tenta "desfetichizar" o estado atual do capitalismo e, de outro, evita um estruturalismo mecanicista que reduz tudo ao movimento puro das "forças materiais". Se é verdade que muitos dos processos se determinam mutuamente ou agem sobre outros criando uma dinâmica que parece automática ou mesmo necessária, as condições que os sustentam e os reforçam foram estabelecidas pela ação dos homens - muitas vezes, como se viu, através de políticas deliberadas:

\footnotetext{
${ }^{94}$ Sobre as holdings e sua lógica transnacional, ver CHESNAIS, A mundialização do capital, cap. 3.

${ }^{9}$ Cf. SERFATI, "O papel ativo dos grupos predominantemente industriais na financeirização da economia". Exemplo: "A mundialização financeira elevou consideravelmente o grau de liquidez e a mobilidade de recursos centralizados por eles [os grandes grupos mundiais]. Ela também provocou a explosão das atividades financeiras dos grupos (...) Com efeito, eles se transformaram cada vez mais claramente em grupos financeiros" (p 142).

96 Harvey menciona, sem fornecer muitos esclarecimentos, uma "classe restrita de chefes-executivos de multinacionais, financistas e rentistas" e complementa dizendo que "surgiu [uma] espécie de classe capitalista transnacional que não obstante se concentrava em Wall Street e outros centros" - HARVEY, O novo imperialismo, p. 151. Além disso, essa "classe" ainda seria pouco ligada a "lealdades ou tradições nacionais ou vinculadas ao lugar" (Ibidem, p. 152), de modo que não foi surpresa que ela recorresse ao hegemon (EUA) para proteger seus interesses e concentrar sua riqueza.
} 
É verdade que muitos dos encadeamentos entre finanças, políticas econômicas atuais e nível de produção e de emprego (...) têm caráter mecânico (...) [Mas] declarar que seriam 'irreversíveis' a hipertrofia financeira e todo o seu séqüito de desgraças é cair num molde muito suspeito de determinismo histórico. ${ }^{97}$

Chesnais empreende, portanto, uma espécie de manifesto contra a idéia de “irreversibilidade”. Há uma incongruência flagrante em aplicá-la à mundialização financeira ao se examinar a história do século XX. Até a Primeira Guerra Mundial, vigia ampla liberdade de movimentação de capitais e, no entre-guerras, as taxas de câmbio eram flutuantes ${ }^{98}$. Além disso, até a Crise de 1929, os mercados financeiros eram "intocáveis". Sabe-se o que ocorreu após a Segunda Guerra Mundial: os Acordos de Bretton Woods instauraram um sistema de finanças administradas, restringindo muito a movimentação internacional de capitais, bem como um regime de taxas de câmbio fixas. Por que, então, a situação atual não poderia ser transformada?

Essa dimensão ideológica, de ocultação das raízes do fenômeno e da possibilidade de mudança, leva à consideração de outro fator importante do exame político do regime financeirizado. Trata-se de explicitar os objetivos almejados pelo neoliberalismo e avaliar em que medida eles foram alcançados. Segundo Chesnais, se forem levadas a sério as alegações, por parte de seus defensores, de que as intervenções de ordem neoliberal tencionavam promover o crescimento da economia, do nível de emprego e do bem-estar social, o balanço é “desfavorável senão desastroso",99.

Já ao se tomar a "revolução conservadora" de Thatcher e Reagan como medidas adotadas pelos países centrais do capitalismo para colocar o poder e a riqueza sob controle das frações superiores da burguesia e de suas instituições, ela foi um enorme sucesso ${ }^{100}$. A liberalização e desregulamentação foram respostas à crise de sobreacumulação e pretendiam dar ao capital a liberdade de movimento que lhe permitiria superar a baixa da taxa de lucro e desenvolver-se mais livremente em um espaço mundializado de valorização do capital. Somadas à securitização da dívida e à elevação das taxas de juros, visaram também eliminar a inflação, criando, assim, condições seguras para as aplicações financeiras e propiciando a

\footnotetext{
${ }^{97}$ CHESNAIS, A mundialização financeira, pp. 31 e 32.

${ }^{98}$ Ver o livro de Barry Eichengreen citado na Introdução, em que ele retraça a história do padrão do ouro e mostra bem as sucessivas transformações ocorridas no cenário econômico mundial a esse respeito. Cf. EICHENGREEN, A globalização do capital.

${ }^{99}$ CHESNAIS, "O capital portador de juros (...)", p. 56.

100 Essa interpretação está em estreito acordo com a de Harvey, que concebe o neoliberalismo como um movimento de recuperação do poder de classe por parte da burguesia.
} 
diminuição dos salários. Sem contar o efeito de alterar profundamente a relação da burguesia com a classe trabalhadora. Esta:

$$
\begin{aligned}
& \text { Iria - com a contribuição da queda da URSS e da tomada de consciência do } \\
& \text { stalinismo - ser deslocada e dar lugar a um assalariado mais indeterminado } \\
& \text { sociologicamente, mais fracamente estruturado politicamente e ainda mais } \\
& \text { vulnerável quanto ao desemprego e às condições de remuneração e de trabalho. }{ }^{101}
\end{aligned}
$$

Na condução desse processo, Chesnais confere, todavia, uma proeminência aos EUA. O regime internacional vigente atualmente, conhecido como "globalização", não teria podido se impor sem o esforço persistente dos EUA durante décadas. Eles erigiram tal regime antes de tudo para seu próprio benefício, com vistas a aproveitar as oportunidades de valorização do capital em escala mundial e manter-se como potência política e econômica dominante. Seu sucesso foi tanto maior na medida em que, com o declínio da URSS, nenhum país pôde oferecer um "contra-poder" ao do capital. Ainda assim, a situação é mais complexa do que aparenta, pois parece não se limitar à questão "nacional" e possuir raízes mais profundas:

\begin{abstract}
Mas quanto mais o tempo passa, é o capital concentrado como tal, tanto financeiro como industrial, que mais aparece como o verdadeiro beneficiário [do atual regime], assim como as oligarquias com grandes fortunas, em qualquer lugar onde elas se encontrem. ${ }^{102}$
\end{abstract}

Embora Chesnais não possua uma teorização própria sobre o Estado, este é certamente um elemento fundamental para a sua perspectiva. A questão do neoliberalismo está muito presente nessa faceta política da análise e indica, como se pretendeu mostrar, uma transformação importante do Estado: ele se torna relativamente impotente para lidar com questões cada vez mais internacionalizadas e para impor limites ao capital privado, sobretudo devido à crise fiscal ${ }^{103}$ e ao enfraquecimento de suas instituições ${ }^{104}$; de modo geral, ele perde igualmente o poder redistributivo e de realizar compensações sociais que possuía antes; progressivamente se "desresponsabiliza" de diversos assuntos, privatizando certos setores; endividado e desprovido de certos instrumentos de macroeconomia, tais como o controle do câmbio e dos fluxos de capital com o exterior, sua atuação se volta cada vez mais para assegurar as bases de sustentação da finança.

\footnotetext{
${ }^{101}$ CHESNAIS, “La prééminence de la finance (...)”, p. 112.

${ }^{102}$ Ibidem, p. 113 (itálico nosso).

103 Importante enfatizar que o aumento dos déficits provocado pelas políticas neoliberais não resulta de "excesso" de gastos, mas de perdas de receitas fiscais: redução do consumo dos assalariados, devido ao arrocho salarial, e diminuição da produção e do nível do emprego. Além, é claro, do corte de impostos sobre o capital Cf. CHESNAIS, "Mundialização financeira e vulnerabilidade sistêmica", p. 260.

${ }^{104}$ Cf. CHESNAIS, A mundialização do capital, pp. 300-301.
} 
Sem entrar no mérito da discussão sobre o Estado ser um simples petit comité de defesa e gestão dos assuntos da burguesia ou possuir uma dinâmica relativamente independente dos interesses imediatos dela ${ }^{105}$, é certo que as forças que dirigem ou influenciam o Estado se alteraram e imprimiram um novo perfil em sua atuação ${ }^{106}$.

Desse modo, o que se vê nos países capitalistas é a constituição de democracias de "fachada"107, nas quais a aparência democrática encobre a dominação de fato de oligarquias rentistas que objetivam enriquecer e reproduzir sua dominação social, política e econômica independentemente de fronteiras nacionais. Como se apontou, essa dominação possui uma de suas sustentações ideológicas mais importantes nos sistemas privados de aposentadoria, cujos beneficiários se encontram cindidos do ponto de vista de sua participação social e política e se contam aos milhões pelo mundo todo.

\footnotetext{
${ }^{105}$ Mesmo porque, conforme Harvey defende, não é necessário abraçar a primeira tese, já que "há outras forças em ação que podem igualmente servir para disciplinar o Estado às exigências do capital". Tais "forças são principalmente financeiras", sendo as crises fiscais o meio último de exercer tal disciplina - HARVEY, Limits to Capital, pp. 152-3.

106 Cabe ressaltar que a idéia de um Estado "mínimo" é falaciosa. O que há é uma reorientação da ação do Estado, como se depreende também dos trabalhos de Harvey sobre neoliberalismo e imperialismo.

${ }^{107}$ CHESNAIS, "La prééminence de la finance (...)", p. 113.
} 


\section{CAPÍTULO 2 - ASPECTOS ECONÔMICOS}

Talvez a caracterização mais geral da dominância financeira seja a de um momento histórico em que o capital portador de juros passa a comandar o capital industrial (processo de valorização), ou em que a "lógica financeira" se sobrepõe à "lógica produtiva" ocasionando mudanças em diversos níveis ${ }^{108}$, com grandes conseqüências sociais e políticas. É isso que Chesnais tem em mente quando escreve que "o mundo contemporâneo apresenta uma configuração específica do capitalismo, na qual o capital portador de juros está localizado no centro das relações econômicas e sociais" ${ }^{\prime 109}$.

Contudo, essa idéia deve ser bem precisada sob pena de criar mal entendidos. É certo que, conforme os dados expostos na Introdução, quantitativamente houve um aumento colossal da riqueza circulando na esfera financeira, que se constitui de capital fictício. Mas isso de modo nenhum significa que atualmente a valorização do capital passe somente pela esfera financeira e que a esfera da produção deixe de ser importante ${ }^{110}$. Mesmo porque, como ficará claro adiante, o termo "valorização financeira" é problemático sob a ótica marxista. De modo que também não se defende que a produção de mercadorias deixa de ser fundamental para a reprodução do capitalismo, o que estaria em flagrante desacordo com a realidade imediata, sobretudo no que se refere ao esgotamento dos recursos naturais e à crise ecológica decorrentes das resistências a qualquer limitação da produção.

O aspecto mais relevante da questão, embora mais difícil de identificar, talvez seja qualitativo. $\mathrm{Ou}$, para ser mais preciso, da mudança qualitativa resultante da ultrapassagem de certo limiar quantitativo do capital portador de juros em circulação - como quer uma das "leis" da dialética. Trata-se de uma reordenação da lógica geral da acumulação do capital em prol da "valorização financeira" - cuja base está evidentemente no seu incrível aumento

\footnotetext{
${ }^{108}$ Importante frisar que, embora Marx não tenha pensado em termos de uma possível fase financeira, percebia claramente o potencial do capital monetário de assumir uma proeminência no sistema capitalista: "O afã de tornar utilizável essa mais-valia, que se entesoura como capital monetário virtual para lucro ou rendimento, encontra no sistema de crédito e nos 'papeizinhos' o alvo de seu anseio. O capital monetário adquire por meio disso, sob outra forma, enorme influência sobre o curso e o desenvolvimento vigoroso do sistema de produção capitalista” MARX, O Capital, Livro II (tomo III), cap. 21, p. 363.

${ }^{109}$ CHESNAIS, “O capital portador de juros (...)”, p. 35.

110 "A tese da dominância financeira é melhor caracterizada não propriamente por uma dominância da valorização financeira, mas por uma dominância financeira da valorização, pois a valorização financeira impõe sua lógica própria à esfera produtiva" - TEIXEIRA, Dependência, desenvolvimento e dominância financeira, p. 82.
} 
quantitativo -, que se reflete na produção de mercadorias como uma submissão desta aos objetivos e modo de funcionamento da esfera financeira.

Embora em última instância o capital financeiro não possa prescindir da valorização produtiva, a desregulamentação dos fluxos de capital em nível mundial o colocou em primeiro plano. A queda do índice de investimento na produção, com a conseqüente "atonia" setor industrial; o surgimento de atores econômicos centrais pertencentes à esfera financeira; o fim de um dinheiro mundial mercadoria, a partir da abolição do lastro-ouro do dólar ${ }^{112}$, que amplia exponencialmente a possibilidade de criação de meios de pagamento; o surgimento da governança corporativa e outras medidas que têm colocado a valorização das ações das empresas como metas mais importantes que o lucro oriundo da produção de mercadorias; crises econômicas freqüentes e de origem financeira, entre outros fatores, indicam o surgimento de novas formas de interpenetração da "finança" com a "indústria", em benefício da primeira.

Segundo Chesnais, essa ascensão do setor financeiro possui três dimensões gerais que serão abordadas ao longo deste capítulo. A primeira é da autonomização da esfera financeira em relação à esfera da produção e ao controle do Estado. Em seguida, tem-se o fetichismo próprio das formas de valorização do capital de natureza financeira (devido ao seu caráter altamente abstrato e mesmo fictício). É ele que está por trás, por exemplo, das bolhas que degeneram em crises e do ímpeto de certo tipo de instituição em fazer dinheiro sem sair da esfera financeira, através dos juros, dividendos, outros pagamentos advindos de ações e da especulação. Por fim, tem-se o poder dos chamados "operadores financeiros" de traçar os contornos e os rumos da economia, ao decidirem quais agentes, de que países e que tipos de transação podem entrar na mundialização financeira.

Este último ponto, menos desenvolvido por Chesnais, está especialmente ligado às três especificidades, apontadas pelo autor, do "espaço financeiro mundial"113 criado pela mundialização. Primeiramente, esse espaço é fortemente hierarquizado, sob hegemonia dos EUA - cujo domínio econômico se baseia na posição única ocupada pelo dólar (de dinheiro mundial) e no tamanho e sofisticação de seus mercados financeiros -, que está associada a

\footnotetext{
${ }^{111}$ CHESNAIS, A mundialização financeira, p. 18.

${ }^{112}$ Uma intensa discussão acerca dos impactos (ou não) que essa desvinculação do dinheiro de uma mercadoria, como o ouro, teria na teoria do valor de Marx foi travada, sobretudo entre autores anglo-saxônicos. Para mais detalhes da discussão ver, por exemplo, MOESELEY, Marx's Theory of Money: Modern Appraisals e SMITHIN, What is money?.

${ }^{113}$ CHESNAIS, op. cit., p. 12.
} 
uma macroeconomia calcada na contribuição do resto do mundo ${ }^{114}$. De modo que há, grosso modo, três posições: a dos EUA - de potência econômica e política dominante, controladora do dinheiro mundial -; a de alguns países que podem se inserir de alguma forma no jogo financeiro, uns de forma bastante subordinada e outros com maior vantagem (certos países europeus, por exemplo); e a dos inúmeros países que não reúnem condições suficientes para se integrar e são excluídos econômica, social e politicamente (exceto pela exploração que sofrem).

Evidentemente esse posicionamento não é fortuito, depende das restrições e incentivos impostos pelos EUA e pelos operadores financeiros em geral. Por isso, Chesnais ressalta que o regime financeirizado não é mundializado no sentido de reunir todos os países em uma "totalidade sistêmica" "115, mas que ele exige, para se consolidar, alto grau de liberalização e desregulamentação em todos os lugares, não só do capital financeiro como também do Investimento Externo Direto (IED). Sua lógica é que funciona em escala global, sem que suas partes se liguem de forma homogênea.

Em segundo lugar, o espaço financeiro mundializado é também carente de instâncias de supervisão e controle, de forma que os operadores possuem ampla margem de ação, sem grandes constrangimentos. É importante enfatizar, a esse respeito, que os termos "liberalização" e "desregulamentação", do receituário neoliberal, possuem um sentido preciso que, contudo, é muitas vezes extrapolado. Eles se referem à liberdade de circulação e de investimento do capital (supervisão e controle), não significando uma ausência de "regras do jogo", que, aliás, são bastante rígidas e viciadas ${ }^{116}$. Certas normas são inclusive alteradas para possibilitar a liberdade de capitais, ou são impostas travestidas de uma supressão ou diminuição de regras. Quando, por exemplo, reduzem-se ou extinguem-se taxações sobre o capital ou sobre as grandes fortunas não se está eliminando uma regra, mas reformulando-a: serão outras classes sociais que pagarão a conta.

A terceira e última especificidade do espaço financeiro mundializado consiste em que sua unidade seja assegurada pelos próprios operadores financeiros. O desenvolvimento tecnológico tem aí um papel fundamental na medida em que permite a interligação em rede de

\footnotetext{
${ }^{114}$ Para uma análise sobre a posição dos EUA no sistema mundial, ver CHESNAIS, “A 'nova economia' (...)”.

${ }^{115}$ CHESNAIS, “A 'nova economia' (...)”, p. 52.

116 Esse "jogo" é descrito em GOWAN, A roleta global. Apesar da palavra "roleta" constar do título em português, o que Gowan pretende mostrar é, diversamente, que o "jogo" ("gamble" no original), não é aleatório, mas sim que Washington "joga" com o mundo impondo certas regras (no original, o livro leva o seguinte subtítulo: "Washington's Faustian Bid for World Dominance").
} 
diversos mercados e o controle das operações por relativamente poucos atores, centralizando a condução do processo. Não obstante o papel da tecnologia, Chesnais faz, na questão da "irreversibilidade" da mundialização, uma crítica do fetichismo tecnológico. A inovação que possibilitou a interconexão dos mercados não surge por acaso - mas em um contexto de desenvolvimento tecnológico específico das sociedades capitalistas - e muito menos gerou a mundialização financeira: "essa interligação nasce das operações que transformam uma virtualidade técnica em fato econômico"117.

Do mesmo modo, a reestruturação produtiva e outras medidas que transformam o processo de trabalho não podem ser atribuídas ao progresso tecnológico em si:

\footnotetext{
Será que as transformações que se deram, nos últimos quinze anos, nas condições de remuneração, de contratação e de trabalho dos assalariados (a relação salarial da teoria regulacionista) (...) podem ser atribuídas unicamente aos efeitos da mudança tecnológica? Ou estariam ligadas também ao crescente peso das finanças e às exigências das novas instituições financeiras não-bancárias? ${ }^{118}$
}

Por fim, Chesnais aponta outras especificidades do presente momento do capitalismo que o distingue sobretudo do período de internacionalização vigente até 1914, sobre o qual os teóricos do imperialismo clássico se debruçaram. Nessa época, os fluxos de capital eram bastante livres e os níveis do IED talvez fossem superiores aos atuais. Contudo, hoje eles estão bem mais concentrados, talvez em um duplo sentido: não somente se destinam a países e mercados menos numerosos, mas o capital em geral está ainda mais concentrado. Além disso, eles estão mais descompromissados: a volatilidade dos investimentos financeiros aumentou devido ao seu perfil "curto-prazista". Consequentemente, as atividades financeiras são atualmente muito mais excludentes, penalizando mais duramente as economias em desenvolvimento. Aproveita-se do valor nelas gerado, normalmente sem contribuir efetivamente para o seu crescimento de longo prazo.

Para se compreender melhor a configuração do capitalismo que se estabeleceu ao longo das últimas décadas, será necessário retomar elementos de $O$ Capital de Marx. Isso será

\footnotetext{
${ }^{117}$ CHESNAIS, A mundialização financeira, p. 12.

${ }^{118}$ Ibidem, p. 19.
} 
feito, seguindo as indicações e comentários de Chesnais, sobretudo em La finance capitaliste, e visa enfatizar o que é crucial para o entendimento de nosso problema.

O primeiro deles é a de que os economistas marxistas poderiam desenvolver melhor duas categorias econômicas importantes construídas por Marx: a de "capital em geral”, e a de "capital fictício". O conceito de "capital em geral" é fundamental devido à sua atualidade, pois "o capital afirma hoje, em um grau jamais atingido antes, os atributos que o fazem um 'valor em processo', uma força impessoal voltada exclusivamente para sua auto-valorização e sua auto-reprodução" ${ }^{\text {119 }}$. Ora, essa é precisamente uma das características mais importantes do capital monetário, cuja forma de valorização "abreviada" (D-D') remete a um alto grau de abstração do capital, já que ele procura prescindir da concretude do processo produtivo e desprender-se de suas "amarras":

Esses atributos incluem a extrema mobilidade dos fluxos de capitais de aplicação e
a imensa flexibilidade nas operações de valorização do capital industrial, a
indiferença quanto à destinação social do investimento ou da aplicação ou às suas
consequiências, etc. $^{120}$

Nesse sentido, a proeminência do capital financeiro no seio do capitalismo contemporâneo parece indicar um passo a mais na aproximação efetiva entre o processo específico de reprodução do capital predominante e sua forma geral, de "valor em processo". Tudo se passa como se o capital financeiro fosse a forma empírica mais acabada que já existiu (e que talvez possa existir) da essência abstrata de auto-valorização do capital. Percebendo isso, Marx afirma que "no capital portador de juros, a relação-capital atinge sua forma mais alienada e mais fetichista"121 e, por isso, decide apresentar e analisar essa função do capital somente no terceiro livro de $O$ Capital. Não é porque ela tenha surgido cronológica e historicamente depois - já que Marx afirma que ela é uma espécie de herdeira da usura medieval -, mas porque ela é posterior logicamente. O capital portador de juros, mas especialmente o capital fictício, é a culminância do processo contínuo de abstração do capital descrito desde o primeiro capítulo do livro.

A segunda categoria importante criada por Marx, a de "capital fictício", é definida então por Chesnais como:

\footnotetext{
${ }^{119}$ CHESNAIS, "La prééminence de la finance (...)", p. 66.

${ }^{120}$ Ibidem, p. 66.

${ }^{121}$ MARX, O Capital, Livro III (tomo IV), cap. 24, p. 293.
} 
Títulos que foram emitidos em decorrência de empréstimos em dinheiro a entidades públicas ou a empresas, ou como expressão da participação inicial no financiamento do capital de uma empresa. Para seus detentores, esses títulos, ações e obrigações, representam um 'capital' do qual eles esperam um rendimento regular sob a forma de juros e dividendos (uma 'capitalização') e que eles desejam poder vender em prazos muito curtos, seja em caso de necessidade de dinheiro, seja para aplicá-lo de maneira ainda mais rentável. ${ }^{122}$

Para Marx, o capital fictício é uma derivação ainda mais "aloucada"123 do capital portador de juros e se apresentava em três formas principais ${ }^{124}$. Vistos sob o ângulo da produção de valor e de mais-valia, os títulos financeiros não são, pois, de fato capital, mas, como explica Chesnais, "no melhor dos casos, são a 'lembrança' de um investimento feito há muito tempo. No momento de crashs e outras crises do mercado financeiro, esse caráter fictício dos títulos se revela e se desmancha à custa de seus detentores"125.

Contudo, na época de Marx as sociedades por ações, o sistema de crédito e os mercados financeiros apenas engatinhavam em comparação com os complexos financeiros de hoje: profusão de produtos financeiros derivados ${ }^{126}$, diversos mercados secundários, fundos de pensão, bancos de investimento, seguros, crédito pessoal, etc. Tudo isso operando a uma velocidade e escala incomparáveis. Nesse sentido, houve o desenvolvimento pleno de processos que Marx apenas pôde apontar ou pressentir, de modo que atualmente os títulos possuem uma enorme capacidade de reproduzir e ampliar a ficção, numa espécie de efeito bola-de-neve ${ }^{127}$. Marx parecia estar inclinado a pensar em momentos cíclicos de ampliação das dinâmicas fictícias que posteriormente seriam desfeitas ou reduzidas nas fases de crise devido à sua falta de base material, para então recomeçar em um período posterior.

${ }^{122}$ CHESNAIS, “La prééminence de la finance (...)”, pp. 66-67.

${ }^{123}$ MARX, O Capital, Livro III (tomo V), cap. 29, p. 10.

${ }^{124}$ Todas essas formas entram na composição do capital bancário: “A maior parte do capital bancário é, portanto, puramente fictícia e consiste em títulos de dívidas (letras de câmbio), títulos de dívida pública (que representam capital passado) e ações (direitos sobre rendimento futuro)" - MARX, O Capital, Livro III (tomo V), cap. 29, p. 13.

${ }^{125}$ CHESNAIS, op. cit., p. 67.

126 "Se a estas formas [de capital fictício já estudas por Marx] agregarmos o atual mercado de derivativos teremos, então, quase todo o capital fictício que impulsiona a acumulação de capital e forma o conjunto de capitais que comandam o processo de acumulação em geral e as formas particulares de gestão das unidades individuais de capital, nesta fase do capitalismo financeirizado" - NAKATANI e HERRERA, Crise financeira... ou de superprodução?, p. 3.

${ }^{127}$ Chesnais afirma que a ficção dos títulos é aumentada "pelo jogo de transações bursáteis que empurra a níveis muito elevados o valor nominal de certos ativos. É aqui que os termos 'irrealista' e mesmo 'fictício' podem aparecer nos comentários dos jornalistas" - CHESNAIS, "La prééminence de la finance (...)”, p. 116. Isso significa que o senso comum compreende a manifestação mais patente da ficção, a exacerbação da diferença entre o preço dos ativos e a realidade da produção, mas não sua essência (ficção inerente aos títulos). 
Provavelmente ele não imaginava que a ficção se perenizaria na economia e com tal magnitude. Dessa forma:

A importância assumida pela centralização e valorização de uma poupança ou de somas de dinheiro que devem ao mesmo tempo participar do valor e da mais-valia, permanecer 'líquida' e servir ficticiamente de 'capital', significa que a teoria atualizada do ‘capital portador de juro’ não pode mais ser excluída da análise do movimento contemporâneo da acumulação e da reprodução do capital. ${ }^{128}$

Essa teoria "atualizada" seria a de um capital de empréstimo ou de aplicação financeira propriamente dito. Marx distinguiu o que ele chamava de "acumulação real" da "acumulação do capital monetário", separando a acumulação via processo produtivo, com extração direta de mais-valia, dos processos tanto mediados pelo empréstimo direto (capital portador de juros na sua versão mais simples) como de caráter propriamente fictício (capital fictício). Entretanto, não é sem relevância tentar compreender qual a diferença específica entre o capital portador de juros na sua forma mais básica e sua derivação fictícia, sobretudo em razão da discussão sobre até que ponto o capital monetário auxilia e dinamiza o processo produtivo ou acaba por subordiná-lo e constrangê-lo.

Um ponto específico da definição de capital fictício é então crucial. Se este, assim como o capital portador de juros, repousa sobre a capitalização de um fluxo de rendas futuras, ele, contudo, não tem nenhuma contrapartida de fato no capital produtivo. O capital portador de juros simples já possui a forma fetichizada D-D', mas em princípio se constitui num empréstimo que se transformará em seguida em capital produtivo criador de mais-valia, com a qual o juro será pago ${ }^{129}$. Ele apenas completa ou se soma ao capital necessário a um determinado processo produtivo, exigindo uma remuneração em contrapartida. Nesse sentido, circunscrito a certo limite, ele tem o efeito de dinamizar a economia, já que antecipa uma produção que, caso contrário, só poderia se dar mais tarde (após uma acumulação maior de capital) ou que não teria condições de ocorrer.

O problema é que esse limite é indeterminável, pois depende da situação econômica vigente e da possibilidade das mercadorias produzidas darem seu "salto mortal" "130 no mercado. Além disso, com a participação das instituições financeiras nas transações e sua

${ }^{128}$ CHESNAIS, "La prééminence de la finance (...)", p. 68 (itálico nosso).

129 "O ponto de partida é o dinheiro que A adianta a B (...) Nas mãos de B, o dinheiro é realmente transformado em capital, percorre o movimento D-M-D' para voltar a A como D', como $\mathrm{D}+\Delta \mathrm{D}$, em que $\Delta \mathrm{D}$ representa o juro (...) O movimento é, portanto: D-D-M-D'-D'” - MARX, O Capital, Livro III (tomo IV), cap. 21, pp. 256 e 257.

${ }^{130}$ Célebre expressão de Marx. 
complexificação e com o aumento do número de operações, dos montantes envolvidos e dos prazos de empréstimo, rapidamente processos de formação de capital fictício se iniciam, o que torna cada vez mais difícil fazer a distinção entre uma operação que possui base real e uma que não possui. O próprio crédito bancário leva a essa situação, uma vez que, como mostrou Marx, seu próprio capital já é fictício.

Essa indeterminação é tal que Chesnais chega a colocar em dúvida a especificidade desse conceito (provavelmente em relação ao de capital portador de juros) devido à centralidade e ao caráter indispensável que ele assume atualmente:

Sob a forma de adiantamentos aos industriais, os bancos criam meios de financiamento que desempenham o papel de capital sem o serem. Trata-se então de uma forma de capital fictício. Esse fato pode parecer retirar do conceito sua força. Se os bancos, auxiliares indispensáveis das empresas, e por isso agentes do aumento das forças produtivas, criam capital fictício permanentemente e seu próprio capital está amplamente composto de créditos e de títulos, então a formação de capital fictício pode ser reduzida ao rol de efeito negativo, sem dúvida desagradável, de uma função central indispensável. O capital fictício de origem bancária é um ingrediente fundamental das crises financeiras. ${ }^{131}$

No crédito comercial simples, em que um elo da cadeia produtiva fornece crédito diretamente ao próximo, a expansão é ainda limitada ${ }^{132}$, embora possa facilitar uma das crises "regulares" da economia capitalista. Com a criação dos mecanismos de desconto de letras de câmbio, o industrial já começa, segundo Chesnais, a se beneficiar de uma ficção devido à antecipação monetária da realização da mercadoria:

Graças ao desconto, ele [o industrial] vê a conversão em dinheiro (e para ele, então, novamente em capital) de mercadorias contendo mais-valia antes que o comerciante as tenha efetivamente vendido. Marx cuida de lembrar que esta ficção, criada e sustentada pelo sistema de crédito, dura somente enquanto o ciclo de valorização se completa para a maioria das empresas. A ficção é fortemente abalada no momento da crise econômica. Sendo curta a duração da vida jurídica dos contratos (frequentemente de três meses) e sendo seu volume pequeno, o desconto não comporta a criação de uma ficção de grande amplitude. ${ }^{133}$

Já com o "crédito do banqueiro", há realmente a possibilidade de um aumento fictício do capital do industrial, já que seu capital é efetivamente completado por um crédito que é,

${ }^{131}$ CHESNAIS, "La prééminence de la finance (...)", p. 83.

132 "O máximo de crédito é aqui igual à mais plena ocupação do capital industrial, isto é, à ativação extrema de sua força de reprodução” - MARX, O Capital, Livro III (tomo V), cap. 30, p. 23.

${ }^{133}$ CHESNAIS, op. cit., pp. 84-85. 
ele mesmo, largamente fictício. A possibilidade da criação de capacidades produtivas que jamais poderão se realizar se vê aumentada exponencialmente. Contemporaneamente, o exemplo do estouro da bolha no setor de telecomunicações dos EUA em 2000 é bastante ilustrativo $^{134}$. O pagamento dos juros está subordinado à finalização do ciclo produtivo, portanto, da efetiva extração da mais-valia. Por conseguinte, é no momento da crise que a ficção fica patente e se desfaz para se adequar à "realidade".

A ascendência que a lógica do capital portador de juros possui sobre os processos econômicos e sociais é tal que Marx identifica uma mudança importante da percepção que se tem sobre o funcionamento da economia. Ela pode ser resumida na inversão aparente da relação entre juro e lucro. Embora este seja o fundamento daquele, afinal o juro é uma fração da mais-valia extraída do processo produtivo, é o juro que passa a figurar como o elemento original e o lucro como algo derivado, como o "não-juro". Essa percepção invertida tem algumas causas, das quais duas são primordiais.

Uma delas diz respeito à maior "visibilidade" da taxa de juros em relação à taxa de lucro. Conforme Marx explica, a taxa média de lucro de uma economia ou setor industrial, como o próprio nome diz, só pode ser obtida pela soma de todas as taxas de lucro individuais, o que não está imediatamente acessível aos capitalistas isolados. Estes só conhecem sua própria taxa. A taxa de juros, ao contrário, sendo, grosso modo, produto da oferta e demanda de capital monetário ${ }^{135}$, é calculada pelo mercado para o todo da economia (ou para diferentes setores) e se apresenta efetivamente como uma taxa fixada. Dessa forma, a taxa de juros adquire ares de algo estatuído e natural ${ }^{136}$, ao passo que o lucro é visto então como o que

${ }^{134}$ Cf. BRENNER, O boom e a bolha, (Introdução à edição brasileira). Segundo ele, após anos de intensos investimentos por meio de empréstimos e emissões de ações no setor desregulamentado das telecomunicações, houve "como inevitável subproduto, um gigantesco excesso de oferta (...) [E] o lucro tornou-se praticamente impossível" (p. 23).

135 Segundo Harvey, há, na realidade, uma "posição de equilíbrio [da taxa de juros] definida em relação à acumulação sustentada" - HARVEY, Limits to Capital, p. 299. A guerra entre capitalistas monetários e industriais quanto à determinação da taxa de juros teria, assim, um papel semelhante à existente entre capitalistas e trabalhadores quanto ao nível dos salários. De todo modo, deve-se observar que os fatores que influenciam na taxa de juros são tão variados que somente por acaso ela atinge o nível de equilíbrio, logo a própria dinâmica do capitalismo tende ao desequilíbrio e, portanto, à crise.

${ }^{136}$ Mesmo que atualmente a estipulação da taxa básica de juros seja prerrogativa do Banco Central, isso é sempre feito alegando-se critérios "técnicos" de avaliação da economia. 
sobra depois de descontado o juro a ser pago. Mesmo capitalistas que não tomam dinheiro emprestado, passam a discriminar em seus balanços o que é lucro e o que é "juro" de seu capital. A possibilidade de fazer seu capital valorizar-se financeiramente passa a fazer parte do "custo de oportunidade" de aplicá-lo produtivamente, como se a taxa vigente de juros assegurasse de fato que aquela remuneração pode ser obtida em qualquer circunstância ${ }^{137}$.

A outra causa da inversão é a noção fundamental que Marx formula para descrever uma das facetas do fetichismo que decorre do poder do capital portador de juros: o princípio da "capitalização". Se a relação estabelecida entre as taxas de juros e de lucro promove uma inversão entre ambos, a capitalização vai além e promove a extrapolação da forma juro para além de sua origem e das situações em que é possível concebê-lo realmente enquanto tal. Ela é responsável pelo próprio processo de formação do capital fictício: "a formação do capital fictício chama-se capitalização. Cada receita que se repete regularmente é capitalizada em se calculando na base da taxa média de juros, como importância que um capital, emprestado a essa taxa de juros, proporcionaria" ${ }^{, 138}$.

Daí a possibilidade, por exemplo, de conceber a dívida pública como capital. Segundo Marx, o título da dívida contra o Estado não é e não pode ser capital. Os rendimentos recebidos pela posse do título são pagos, portanto, com as receitas futuras do Estado (impostos, e não mais-valia diretamente extraída de um processo produtivo). O preço de mercado do título é então calculado a partir de um raciocínio às avessas: tomando-se a taxa de juros vigente e o montante do rendimento pago, calcula-se o valor do "capital" representado pelo título:

\footnotetext{
A forma de capital portador de juros faz com que cada rendimento monetário determinado e regular apareça como juro de um capital, quer provenha de um capital ou não. Primeiro, o rendimento monetário é convertido em juro e com o juro se acha então o capital de que se origina. Do mesmo modo, com o capital portador de juros cada soma de valor aparece como capital, desde que não seja despendida como rendimento; a saber, como soma principal (principal) em antítese ao juro possível ou real que pode proporcionar. ${ }^{139}$
}

\footnotetext{
${ }^{137}$ Evidentemente, esse fetiche do juro não se sustenta quando grande parte dos capitalistas coloca, ao mesmo tempo, seu capital para se valorizar financeiramente, ou então em certos momentos da crise, quando a demanda por capital monetário diminui. A taxa de juro cai a ponto de não permitir ganhos, mostrando que sem produção real não há como se pagar juros (Cf. MARX, O Capital, Livro III (tomo IV), cap. 23, p. 282). Como ironiza Marx, dinheiro não produz dinheiro naturalmente como "pereira produz pêras".

${ }^{138}$ MARX, O Capital, Livro III (tomo V), cap. 29, p. 11.

${ }^{139}$ Ibidem, cap. 29, p. 10.
} 
Outro exemplo dado pelo próprio Marx ${ }^{140}$, pleno de ironia, faria regozijar-se qualquer teórico do capital humano. O próprio trabalhador poderia ser considerado um "capital", sendo o seu salário o "juro" que o remuneraria. Dada a taxa de juros vigente e o salário, pelo mesmo raciocínio às avessas, obtém-se o valor do trabalhador como força de trabalho. Vê-se assim, como a lógica impregnada do juro pode criar capital fictício a partir de praticamente qualquer coisa. Qualquer soma de dinheiro, ou mesmo o que nem dinheiro é, pode ter seu "juro potencial" calculado. A forma juro desenvolve, portanto, a um grau ainda mais elevado a "contradição qualitativa"141 que Marx define como uma característica do fetiche da forma preço: assim como esta possibilita que se compre aquilo que não possui valor, como a consciência, a honra, etc., o juro tem a capacidade de transformar em "capital" aquilo que não o é en $^{142}$.

Evidentemente, os desenvolvimentos do princípio da capitalização manifestados, por exemplo, na enorme diversificação e multiplicação dos ativos e produtos financeiros, levamno a imprimir sua marca de modo decisivo na configuração do capitalismo e a delinear características importantes da financeirização. Duas delas são destacadas por Chesnais como elementos essenciais: a exterioridade da finança em relação à produção e sua "insaciabilidade" ${ }^{143}$ de apropriação de riqueza.

A questão da exterioridade deriva da distinção que Marx faz entre capitalista passivo e ativo, ou seja, entre capitalista monetário que empresta seu capital na forma dinheiro ${ }^{144}$ e o capitalista produtivo que efetivamente converte-o em produção de mercadorias. Essa cisão engendra um "confronto" entre duas "espécies" de capitalista ${ }^{145}$ acerca da apropriação da mais-valia (que de certa forma é encontrado também na relação entre proprietário-acionista e administrador da empresa). A taxa de juros - para além de um simples produto da oferta/demanda de capital monetário - funciona também como um sinalizador do estado da

\footnotetext{
${ }^{140}$ Cf. MARX, O Capital, Livro III (tomo V), cap. 29.

${ }^{141}$ MARX, O Capital, Livro I (tomo 1), cap. 3, p. 92.

${ }^{142} \mathrm{O}$ fetiche da forma juro é tão potente e espraia-se de tal forma pela sociedade, que é possível, de modo mais preciso, concebê-lo como uma manifestação da "reificação". Embora este conceito de Georg Lukács (Cf. LUKÁCS, História e consciência de classe) seja essencialmente o mesmo que o "fetichismo da mercadoria" de Marx, ele possui uma ênfase mais explicitamente social. Enquanto a análise de Marx em $O$ Capital concentra-se na origem econômica do obscurecimento da realidade, Lukács visa mostrar como esse fenômeno se manifesta em outras esferas: filosofia, ciência, direito, etc.

${ }^{143}$ CHESNAIS, "O capital portador de juros (...)", p. 60.

144 Não é necessário que o capital esteja na forma monetária. Porém, para simplificar, e por ser a forma largamente predominante, o capital portador de juros será tratado como capital monetário.

145 "Se o capitalista trabalha com o capital próprio ou emprestado, em nada altera a circunstância de que a classe dos capitalistas monetários se lhe confronta como espécie particular de capitalista” - MARX, O Capital, Livro III (tomo IV), cap. 23, p. 281.
} 
"batalha", já que define quanto da mais-valia corresponderá ao lucro e quanto será pago como juro.

No plano mais estrutural, trata-se, portanto, fundamentalmente da oposição entre capital-propriedade e capital-função. Tanto emprestadores de dinheiro como acionistas concebem a valorização de seus respectivos capitais a partir da forma simplificada D-D', ou seja, concebem o capital de forma abstrata, como um "valor em processo" fora do circuito real D-M-D'.

Nesse sentido, para o capitalista passivo individual, a produção está fora do ciclo de valorização de seu capital. Este parece não sair da esfera da circulação, donde o "mistério" de seu incremento quantitativo, que figura como ilimitado e natural. Em última instância, pouco lhe importa o emprego efetivo do capital (em qual processo produtivo, em que circunstâncias, etc.) desde que o juro devido seja pago ${ }^{146}$. A idéia da exterioridade da finança em relação à produção não significa, portanto, que aquela prescinda desta, mas que seu "olhar" sobre ela é externo. $\mathrm{O}$ rol de suas atividades e preocupações não passa diretamente pela questão da produção. Sob esse aspecto, o capitalista monetário assemelha-se ao proprietário fundiário: possui o direito a uma renda pela simples propriedade, no seu caso do capital e não da terra, sem participação efetiva na produção de valor.

A re-ascensão da finança nos anos 1970 se constitui, pois, em um ponto de inflexão. O poder dos acionistas é restituído vigorosamente e materializa-se na generalização das sociedades por ações (e holdings) como forma de organização e estruturação das empresas, sobretudo entre os grandes grupos industriais. A balança pende, assim, indubitavelmente para o lado da finança e consolida o "rentismo" - termo derivado da apropriação que Chesnais realiza da noção de Aglietta de "regime patrimonial", no qual "um patrimônio designa uma propriedade mobiliária e imobiliária que foi acumulada e dirigida para o "rendimento",147.

Embora no capitalismo não seja razoável pensar em uma propriedade que não esteja dirigida para a obtenção de alguma remuneração - sendo a figura do entesourador, por exemplo, "obsoleta" - Chesnais defende a existência de uma nuance. O "rentista", dono de um patrimônio, é mais do que um simples “credor”, pois este de alguma forma participava de um "financiamento efetivo" e possuía uma relação direta com o empreendimento

\footnotetext{
${ }^{146}$ Com as facilidades tecnológicas atualmente disponíveis no mercado financeiro, pode-se investir em papéis de empresas muito distantes, que figuram como uma abstração para o acionista.

${ }^{147}$ CHESNAIS, "O capital portador de juros (...)”, pp. 48 e 49 (itálico nosso).
} 
financiado $^{148}$. Os mercados secundários esgarçam essa relação, pois o que é negociado são os títulos de propriedade e de dívida, o financiamento já tendo virado algo do passado. A propriedade patrimonial não é orientada para fomentar o consumo, nem a geração de investimentos que incrementem a produção, mas sim para proporcionar com regularidade um "rendimento". Assim, "os mercados de obrigações lhe permitem [ao investidor] jamais conhecer seus devedores dos empréstimos. Seu problema não é saber 'quem pagará o mico', mas saber se os mercados permanecerão líquidos"149.

O controle "de dentro" das empresas por uma lógica que lhe é "exterior" levou Chesnais a formular o problema em termos de uma internalização ou alojamento da exterioridade da finança no seio da produção. Se antes a disputa entre capital-propriedade e capital-função se travava fora, através da taxa de juros, por exemplo, ou estava contida pela dominância dos administradores ${ }^{150}$, agora as pressões por rentabilidade e valorização das cotações das ações se exercem com força diretamente no comando da empresa.

O curto prazo da lógica financeira "exterior", por exemplo, passa a se sobrepor ao longo prazo da produção e do investimento, com conseqüências importantes. Primeiramente, para os trabalhadores - devido às reestruturações produtivas, diminuição de salários, etc. a fim de atender às normas de rentabilidade. Mas também para o setor industrial em geral, no sentido da desaceleração de seu crescimento, o que contraditoriamente ameaça as bases da geração de valor necessárias ao lucro financeiro. Assim:

A liberalização e a mundialização financeira deram aos mais importantes proprietários de ações e obrigações (...) os meios de influir sobre a repartição da renda em duas dimensões essenciais: a da distribuição da riqueza produzida entre salários, lucros e rendas financeiras, e a da repartição entre a parte atribuída ao investimento e a parte distribuída como dividendos e juros. Como as duas determinações da repartição afetam o nível do investimento e comandam o emprego e o crescimento, é difícil imaginar um poder mais forte da finança. ${ }^{151}$

\footnotetext{
${ }^{148}$ Ele talvez esteja ligado ao capital portador de juros na sua forma mais simples, como sugere a seguinte passagem: "O termo 'credor' remete a empréstimo, cuja figura tutelar é a banca e no qual a 'finança', sob a forma de crédito, engendra relações diretas entre a banca e os beneficiários do empréstimo cuja base é um financiamento efetivo." - CHESNAIS, “O capital portador de juros (...)”, p. 49.

${ }^{149}$ Ibidem, p. 49.

${ }^{150}$ Com o surgimento das sociedades por ações, mas principalmente com o entrelaçamento entre os dois tipos de capital apontado por Hilferding, já há condições para que os interesses da finança comecem a se alojar na produção, mas eles permanecem ainda limitados pelo enfraquecimento dos acionistas e das bolsas após a Crise de 29.

${ }^{151}$ CHESNAIS, A finança mundializada, p. 27.
} 
Segundo Chesnais, portanto, com a dominação econômica e social do capital portador de juros, as contradições "clássicas" do capitalismo não são superadas, mas se combinam com novas contradições e processos antagônicos que possuem uma dupla origem. De um lado, a "acumulação branda"152 generalizada - constatável pelas baixas taxas de crescimento dos países da OCDE em comparação com o período dos chamados Anos Dourados ${ }^{153}$ - decorrente da lógica de curto prazo. De outro, a “'insaciabilidade' da finança quanto ao nível de suas punções" ${ }^{, 154}$ que tornam mais agudos os problemas da acumulação.

Essa insaciabilidade liga-se a uma contradição profunda entre valorização exigida e efetiva. Embora o capital sob todas as suas formas possua uma propensão inerente à acumulação sem limites, a posição de exterioridade à produção em que os agentes e instituições financeiros estão potencializa-a ${ }^{155}$. O caráter abstrato e fetichista do circuito D-D' no qual a finança opera, em que apenas se tem dinheiro no início e mais dinheiro no final, não oferece nenhuma baliza às exigências de retorno financeiro ${ }^{156}$. As instituições financeiras:

Impelem a seu máximo desenvolvimento tudo o que está contido na categoria de dinheiro que se transforma em capital, como força dirigida para a expropriação e a exploração. É de sua abstração que o capital obtém a fluidez e a mobilidade que lhe permitem se mover pelo planeta. ${ }^{157}$

A insaciabilidade da finança constitui, assim, uma das forças propulsoras (econômicas e políticas) diretas ou indiretas de diversos processos. Primeiramente, de desregulamentação do trabalho, que leva ao aumento da extração de mais-valia e permite que mais valor seja revertido para o circuito financeiro ou passe para as mãos dos proprietários. Em segundo lugar, de desmantelamento dos sistemas de aposentadoria por repartição em prol do fortalecimento dos fundos de pensão, o que conferiu mais poder para a finança ao incluir elevadas somas nos circuitos financeiros. E, em terceiro lugar, de privatização de indústrias e serviços, o que abre novas frentes de valorização para o capital - muitas vezes em estado de

${ }^{152}$ CHESNAIS, “O capital portador de juros (...)”, p. 60.

${ }^{153}$ Cf. CHESNAIS, "Mundialização financeira e vulnerabilidade sistêmica”, p. 252. Mais recentemente, segundo dados da OCDE, as taxas médias de crescimento do PIB para o conjunto dos países da OCDE entre 2005 e 2009 foram, respectivamente: $2,7 \%, 3,1 \%, 2,7 \%, 0,6 \%$ e $-3,3 \%$ (OCDE, Comparison of gross domestic product (GDP) for OECD member countries).

${ }^{154}$ CHESNAIS, “O capital portador de juros (...)”, p. 60.

155 “A propensão do capital portador de juros para demandar da economia 'mais do que ela pode dar' é uma consequiência de sua exterioridade à produção" - CHESNAIS, “O capital portador de juros (...)”, p. 61.

156 "No capital portador de juros está, no entanto, consumada a concepção do fetiche-capital, a concepção que atribui ao produto acumulado do trabalho, e ainda fixado na forma dinheiro, o poder de produzir, em virtude de uma qualidade inata e secreta, como um puro autômato, em progressão geométrica, mais-valia." - MARX, $O$ Capital, Livro III (tomo IV), cap. 24, p. 299.

${ }^{157}$ CHESNAIS, "La prééminence de la finance (...)", p. 73. 
sobreacumulação - e oferecem fluxos regulares de rendimentos. As privatizações constituíram, pois, o centro das políticas governamentais neoliberais de sustentação dos mercados financeiros.

Essa impetuosidade da finança passa a moldar a sociedade e a tendência capitalista de a economia se sobrepor às demais esferas reforça-se qualitativamente. Todos parecem ter que se adaptar às suas exigências recorrendo a todos os meios, inclusive aos mecanismos bárbaros da acumulação primitiva. Nesse sentido, Chesnais formula uma proposição bastante "sociológica" que tem sua origem nos escritos de Marx, mas que parece ganhar atualidade especial: “Enfim, quanto mais a forma D - D' torna-se predominante, mais o fetichismo, as representações fantasmagóricas das fontes da riqueza se apossam da sociedade"158.

O surgimento e generalização das sociedades por ações foram, portanto, um dos fatores que possibilitaram a difusão e a consolidação desse domínio do capital fictício e do capital como "patrimônio". As sociedades anônimas são o veículo concreto da internalização da exterioridade da finança e de sua punção insaciável, na medida em que transpõem a cisão entre capital-propriedade e capital-função para dentro da empresa.

Antes das sociedades por ações, as figuras do capitalista passivo/monetário e do capitalista ativo/produtivo eram bastante distintas: a primeira era externa ao processo produtivo, apenas se interessando pelo ganho a ser obtido com o empréstimo de seu capital, e a outra estava diretamente implicada no processo produtivo, convertendo o dinheiro em meios de produção e força de trabalho e comandando o processo de produção. A remuneração do capitalista exterior à produção consiste no juro e deriva da propriedade do capital ${ }^{159}$, e a do que comanda o processo de produção é o lucro. Este é chamado também pela forma fetichizada de "ganho empresarial", exatamente por sugerir que o capitalista ativo obtém uma remuneração pela sua capacidade empresarial, pelo seu "trabalho" de gestor da produção e pelos "riscos" que esta envolve:

${ }^{158}$ CHESNAIS, “La prééminence de la finance (...)”, p. 73.

159 Lembremos que com a dominância da forma juro, mesmo o capitalista que trabalha com capital próprio estabelece para si essa divisão qualitativa. O juro é o que remunera a propriedade do seu capital e o lucro a sua implicação no processo produtivo. Nesse caso, não há muitas consequiências, pois juro e lucro são pagos à mesma pessoa, contudo é muito ilustrativo de como a forma juro se impõe à consciência das pessoas. 
O ganho empresarial lhe [ao capitalista ativo] aparece agora como fruto exclusivo das funções que ele desempenha com o capital, fruto do movimento e do processamento do capital, o que lhe aparece agora como sua própria atividade, em oposição à inatividade e à não-participação do capitalista monetário no processo de produção. $^{160}$

Desse modo, Marx comenta: "temos que partir do pressuposto de que o capitalista monetário e o capitalista produtivo se confrontam realmente não apenas como pessoas jurídicas diversas, mas como pessoas que desempenham papéis totalmente diferentes no processo de reprodução"161.

As sociedades anônimas, contudo, tornam essas relações mais complexas. A figura do capitalista monetário completamente "exterior" à produção continua a existir, na forma de emprestadores de dinheiro como, por exemplo, os bancos. Já o capitalista ativo se vê cindido em dois agentes: os acionistas - representantes da propriedade pura do capital, e que por isso agem como capitalistas monetários - e os administradores - representantes do capital em funcionamento sem a propriedade, mas que por isso mesmo deixam de ser capitalistas de jure $^{162}$. Essa cisão dilui ainda as fronteiras entre o ganho empresarial e o juro, já que o lucro não reinvestido na produção é pago como juro (porque destinado aos proprietários do capital) sob forma de dividendos.

Nesse sentido, enquanto os bancos e outros agentes externos são emprestadores de dinheiro (credores que receberão juros), os acionistas realmente se tornam proprietários da empresa e só o deixarão de ser ao venderem sua parte a outrem. Desse modo, eles são efetivamente donos da empresa, mas se situam logicamente de um ponto de vista exterior a ela. Por terem assento no conselho de administração - mas para além disso, já que a valorização financeira de qualquer forma se impôs como norma devido aos princípios da governança corporativa ${ }^{163}$-, os acionistas comandam diretamente as regras e metas da empresa. Porém, o fazem com interesses próprios de capitalistas financeiros, principalmente

\footnotetext{
${ }^{160}$ MARX, O Capital, Livro III (tomo IV), cap. 23, p. 280.

${ }^{161}$ Ibidem, cap. 23, p. 279.

162 O ganho empresarial recebe, assim, a designação mais fetichista de "salário de superintendência". A possibilidade de o capitalista ativo delegar sua função de supervisionar e gerir o processo de produção a um administrador ou gerente, pagando-lhe um salário, mostra que em última instância não existe propriamente uma atividade especificamente capitalista e que o elemento definidor do capital é a propriedade dos meios de produção. Além disso, fica evidente que a remuneração do capitalista advém da magnitude do capital e não do tipo ou qualificação de um trabalho supostamente executado por ele.

${ }^{163}$ Nesse sentido, apesar da hierarquia existente entre os acionistas, já que a maior parte deles não tem assento nos conselhos de administração, os interesses que os unem - o recebimento do maior rendimento possível estão assegurados pela lógica de administração das empresas.
} 
porque atualmente muitos deles são instituições financeiras, tais como os fundos de pensão e de investimento. Esse movimento de "institucionalização" dos acionistas leva a uma despersonalização ainda maior do suporte do capital, tornando mais voraz o impulso à valorização. Por isso, os acionistas são o pivô da internalização da exterioridade da finança e da maximização das punções da riqueza originada na produção.

O administrador, de modo diverso, é uma reminiscência do capitalista ativo, mas sem propriedade alguma e sem compromisso umbilical com o empreendimento. Ele é um funcionário da empresa que pode ser inclusive demitido e, segundo afirma Marx, recebe um salário regulado pelo mercado ${ }^{164}$. Segundo Chesnais, em decorrência de sua situação, sua atuação administrativa seria diferente: a inclinação, por exemplo, a assumir riscos tende a ser muito maior do que a do capitalista ativo tradicional ${ }^{165}$, sobretudo no atual contexto de concorrência extremada entre os grandes grupos industriais e de pressão dos acionistas por maior rentabilidade de seus ativos.

Por outro lado, a figura do administrador encerra também certa ambigüidade. Malgrado sua relação direta com a direção do processo produtivo, ele é muitas vezes remunerado por meio das stock options, mecanismo que o atrela aos interesses da finança. Consequentemente, até o que resta do capitalista ativo acaba se comprometendo com o capital enquanto propriedade.

Quanto aos trabalhadores, os impactos da sociedade por ações não são menores. A eleição da valorização acionária e do pagamento de dividendos como prioridade se reverte na busca da máxima rentabilidade a curto prazo e de maior "liquidez" dos "ativos", estejam eles materializados em meios de produção ou em força de trabalho. Donde toda sorte de reestruturação produtiva que visa a "flexibilizar" ou "aliviar o peso" do processo produtivo, sobretudo no que se refere aos trabalhadores.

\footnotetext{
164 “O ordenado do dirigente é ou deve ser mero salário por certa espécie de trabalho qualificado, cujo preço é regulado no mercado de trabalho, como o de qualquer outro trabalho" - MARX, O Capital, Livro III (tomo IV), cap. 27, p. 332. Todavia, assumindo que o administrador representa essa faceta ativa do capitalista e dado seu comprometimento pessoal e ideológico com a empresa e com a reprodução do capital, não parece descabido conceber sua remuneração como um "salário de superintendência", no sentido de uma fração da mais-valia e não do capital variável.

${ }^{165}$ Harvey também observa, a propósito do surgimento das sociedades por ações no final do século XIX, que: "a separação entre propriedade e administração ajudou a superar as limitações administrativas da empresa tradicional familiar [old-style family firm]. [Mas Adam Smith] considerava as sociedades por ações como permissões para administradores irresponsáveis especularem com dinheiro alheio" - HARVEY, Limits to Capital, p. 146.
} 
Assim, se Marx, em um contexto preciso, afirma que para o trabalhador é indiferente que o capitalista tenha que dividir a mais-valia por ele extraída com uma "terceira pessoa" ou não ${ }^{166}$, vê-se que nesse contexto surgem grandes diferenças. A existência dessa "terceira pessoa" e a posição de poder ocupada por ela atualmente nos circuitos de valorização do capital imprimem de modo contundente sua marca.

No que se refere especificamente à questão da liquidez, as holdings são uma forma de "liquidificar" os ativos materiais da empresa ${ }^{167}$. São um modo mais apurado de gestão financeira, atuam de modo internacionalizado e se compõem de uma matriz e diversas filiais. Estas são empresas dedicadas a alguma atividade produtiva específica, ao passo que a matriz é um "centro de decisão financeiro" "168 que arbitra entre as atividades de suas filiais de modo a obter maior rentabilidade ${ }^{169}$. As atividades em si não importam tanto para as decisões de investimentos, mas sim a maior lucratividade combinada das unidades de produção. É bastante comum, inclusive, que as holdings possuam bancos próprios para operacionalizar os financiamentos/empréstimos. Uma vantagem adicional reside também na possibilidade de transferências de mercadorias e dinheiro intra-holding, evitando ou diminuindo o pagamento de impostos e praticando preços reduzidos.

Dado que o acionista, sobretudo o institucional, não está só interessado nos dividendos, mas também na liquidez dos seus ativos, os gestores de fundos preferem ter negócios com esse tipo de empresa "cuja forma jurídica permite o tratamento do grupo como um conjunto de ativos financeiros quase líquidos" ${ }^{170}$.

\footnotetext{
166 "Para o trabalhador, é inteiramente indiferente que ele [o capitalista] faça isso [embolsar todo o lucro] ou tenha de pagar uma parte a uma terceira pessoa, como proprietária jurídica" - MARX, O Capital, Livro III (tomo IV), cap. 23, p. 284. A frase se explica pelo seu contexto: o intuito é de desmistificar a diferença qualitativa entre lucro e juro, mostrando que eles não passam de uma divisão quantitativa da mais-valia e que por isso não há qualquer diferença específica na relação entre eles e o trabalho.

167 "O objetivo dos fundos é valorizar seus ativos industriais, pelos mesmos critérios que os seus ativos financeiros como um todo" - CHESNAIS, A mundialização do capital, p. 293. Ou seja, buscando rentabilidade, mobilidade e flexibilidade máximas com o menor risco possível. Nesse sentido, em termos comparativos, nos diz Chesnais, a situação na Alemanha descrita por Hilferding pareceria uma espécie de "Idade de Ouro", na medida em que o "capital financeiro" aparenta ser a melhor forma de organização da relação entre o capital dinheiro e a produção. Eram "só” os bancos que tinham interesse na indústria e não todo um conjunto de novos investidores institucionais obcecados pela liquidez.

${ }^{168}$ CHESNAIS, A mundialização do capital, p. 75.

169 "Mais que critérios industriais, aqui ainda são as opiniões dos investidores, moldadas pelos analistas financeiros, que decidirão sobre o grau de centragem, sendo os elementos bursáteis os determinantes" CHESNAIS, "La prééminence de la finance (...)", p. 110.

${ }^{170}$ Ibidem, p. 110.
} 
O tipo de descomprometimento que o acionista pode ter em relação ao empreendimento do qual é dono - de tratá-lo não como um capital produtivo, cujo valor só poderá ser recuperado a longo prazo, mas sim como um capital monetário - só é possível graças à liquidez proporcionada pela negociação em bolsa das ações e títulos. Caso contrário, ele estaria em condição semelhante à do capitalista produtivo tradicional, que não podia desvencilhar-se tão facilmente do capital "empatado" na produção. Mesmo o capitalista emprestador de dinheiro, que a princípio precisaria esperar para retomar seu capital, também pode reavê-lo vendendo a dívida da qual é credor no mercado financeiro ${ }^{171}$. De modo que o papel primordial das bolsas de valores, particularmente dos mercados secundários, é propiciar liquidez necessária ao funcionamento das atividades financeiras e das sociedades por ações, facilitando as transações e reunindo-as em um só "lugar" (ou em várias praças interligadas, como atualmente).

As ações são títulos de propriedade sobre rendimentos de um capital que está em sua forma produtiva, em pleno funcionamento. Ao contrário do empréstimo, no qual, a princípio, o capital retorna junto com os juros ao final do prazo estipulado (ou em parcelas), a ação representa uma aquisição, uma capitalização definitiva da empresa. Só no interior das bolsas elas ganham essa espécie de segunda existência e podem ser facilmente vendidas de modo a devolver ao capital sua forma monetária. Nesse sentido, é interessante a observação de Chesnais, baseada em Hilferding e Marx, de que, com a sociedade por ações, há uma mudança não desprezível do que seja a "propriedade" (pelo menos para a grande maioria dos acionistas): aquilo que era um direito efetivo de dispor dos meios de produção torna-se um mero título de renda, de participação nos lucros produzidos ${ }^{172}$.

Tal transformação provavelmente ocorre precisamente devido a essa cisão radical entre propriedade e função do capital levada a cabo pela sociedade por ações; e a sua

\footnotetext{
171 Através da securitização, diluindo a dívida entre diversos credores e podendo reaver a quantia emprestada antes do prazo de devolução. A famosa crise do sub-prime foi relativa a operações desse tipo: os bancos venderam a dívida hipotecária de famílias cujo nível de renda as colocava na categoria de alto risco de inadimplência.

${ }^{172}$ Cf. CHESNAIS, "La prééminence de la finance (...)", p. 95.

Duménil e Lévy detalham melhor esse ponto: "a propriedade individual está ultrapassada. Os proprietários se desincumbiram da gestão e, progressivamente, de sua outra função social (...), de arbitrar a aplicação de seus fundos (...) entre as empresas e os setores. Resta-lhes, entretanto, a possibilidade de impor as regras de funcionamento próprias ao capitalismo: a maximização da taxa de lucro e a transformação dos lucros das empresas em rendas dos proprietários (dividendos) - DUMÉNIL e LÉVY, "Superação da crise, ameaças de crises e novo capitalismo", p. 35.
} 
contrapartida, ou faceta simétrica, talvez seja exatamente a possibilidade de se desvencilhar rapidamente dessa mera propriedade, "passando-a adiante".

O comprador, ao adquirir esse título que lhe garantirá a apropriação das rendas futuras geradas pela empresa, restitui ao vendedor da ação o seu "capital" - entre aspas, porque, embora o comprador recupere seu dinheiro, o capital em si que foi aplicado não muda e continua, como antes, investido na produção:

A ação é, pois, sem dúvida um título de rendimento, um título de dívida sobre a futura produção, uma ordem de pagamento de lucros. Uma vez que o lucro é capitalizado e que a soma capitalizada constitui o preço da ação [raciocínio às avessas do qual se falou anteriormente - I.L.], o preço da ação parece conter um segundo capital. Mas é ilusão. O que existe, de fato, é o capital industrial e o respectivo lucro. ${ }^{173}$

E, nesse sentido, Hilferding afirma mais abaixo:

O movimento de ações não é movimento de capital, senão apenas uma compra e venda de títulos de renda; as oscilações de seus preços não afetam diretamente o capital industrial realmente ativo, cujo rendimento elas representam, mas não o seu valor. Além de depender do rendimento seu preço também depende do nível da taxa de juros pela qual são capitalizados. As variações dessa taxa são totalmente independentes do que ocorre com o capital industrial individual. Essas considerações em si já bastam para deixar claro que não tem cabimento considerar o preço das ações como parte alíquota do capital industrial. ${ }^{174}$

Em momentos de crise, quando as ações perdem valor e no limite podem não encontrar compradores, é que se percebe que aquele "papelzinho" (no falar jocoso de Marx) pode não corresponder a um capital efetivo e que seu preço foi determinado pelo raciocínio às avessas da capitalização.

Enfim, como resume Chesnais:

Por isso são necessários os mercados especializados, as Bolsas, nos quais os títulos de propriedade podem ser vendidos. Sua existência é indispensável para a constituição de sociedades por ações. Com efeito, as ações são 'títulos sobre capital real'. Mas elas 'estabelecem somente direitos sobre uma fração da mais-valia da qual ele [o capital real] vai se apropriar'. 'Mas [os títulos] não permitem dispor deste. Ele não pode ser retirado'. Somente o mercado bursátil permite ao investidor financeiro recuperar seu capital-dinheiro, para aplicá-lo de outra forma ou para

${ }^{173}$ HILFERDING, O capital financeiro, p. 114.

${ }^{174}$ Ibidem, p. 114. 
gastá-lo. A Bolsa reforça ainda a dimensão fictícia das ações devido às oscilações dos preços dos títulos. ${ }^{175}$

As citações de Hilferding no texto de Chesnais não são casuais. Este se dedica a uma análise específica de Hilferding por considerá-lo o primeiro - e praticamente único - marxista a se debruçar sobre a questão da finança e dos mercados financeiros e um teórico original do funcionamento e do papel das bolsas (mostrando essa necessidade que a finança tem de uma instituição que garanta a liquidez $)^{176}$. Chesnais defende que, na realidade, ele fornece duas definições gerais do capital financeiro, ambas se referindo a uma "unificação do capital" ${ }^{177}$, mas de modos distintos ${ }^{178}$.

A primeira, que será designada como sociológica ou política, é a mais conhecida e citada. Ela enfatiza a reunião dos capitais industrial, comercial e bancário através da associação de seus respectivos representantes, dos suportes reais de cada tipo de capital: os "senhores" da indústria e dos bancos. O capital financeiro seria, portanto, a unificação dos diferentes setores do capital sob o comando das "altas finanças"179.

Já a segunda definição, entendida aqui como mais estrutural ou econômica, prolongaria, segundo Chesnais, os elementos estabelecidos por Marx. Trata-se da centralização dos capitais parciais sob a dominância da forma de valorização D-D'. Isso diz respeito não somente à associação dos diferentes setores do capital, mas também à reunião das pequenas somas de capital-dinheiro que antes não atingiam uma quantidade suficiente para serem postas para se valorizar. De modo que o capital financeiro figura como grandes somas

${ }^{175}$ CHESNAIS, "La prééminence de la finance (...)", p. 88 (os colchetes constam do original e os trechos entre aspas são citados de HILFERDING, Le capital financier).

176 "Hilferding é o primeiro teórico, depois de Marx, a ter verdadeiramente se dedicado à análise da finança e permanece praticamente sozinho"; "Ele enuncia uma teoria da Bolsa bastante avançada, que não existe em Marx, mostrando como os bancos, assim como as sociedades por ações, têm necessidade de ser secundados por uma instituição que garanta a liquidez dos títulos" - CHESNAIS, "La prééminence de la finance (...)", pp. 90 e 92 respectivamente (itálico nosso).

${ }_{177}$ Cf. Ibidem, p. 90-91.

${ }^{178}$ Importante notar que os dois aspectos que Chesnais identifica no conceito de capital financeiro também não são estranhos à análise de Harvey, que identifica duas "visões" sobre ele: a de um modo de circulação do capital e a da formação de blocos de poder no interior da burguesia.

${ }^{179}$ Os dois termos entre aspas são de Hilferding. Embora na edição francesa do livro de Hilferding essa ligação "pessoal" não fique textualmente explícita, nas traduções em português e em inglês não restam dúvidas: nas altas finanças "estão reunidos, em estreita união pessoal, os senhores da indústria e dos bancos" (itálicos nossos) ou "the masters of industry and of the banks are united in a close personal association" (itálicos nossos) HILFERDING, $O$ capital financeiro, p. 283 e HILFERDING, Finance Capital, cap. 21 ( $1^{\circ}$ parágrafo), respectivamente. 
de capital-dinheiro que buscam a valorização pelo circuito abreviado e "sem sentido" 180 da fórmula D-D', transformando o processo geral de acumulação do capital.

Por conseguinte, a centralização operada pelo capital financeiro é tão poderosa que não se trata apenas de fusões de capital intra-setorialmente - como, por exemplo, a compra de uma empresa por sua rival no jogo da concorrência -, mas sim da combinação das diversas formas de capital em um novo arranjo. Embora cada espécie de capital conserve as especificidades de seus ciclos de reprodução, todos passam a estar sob a hegemonia do circuito D-D’. Chesnais chega a citar a idéia de Hilferding de um processo dialético de "negação da negação"181 que opera no movimento de consolidação do capital financeiro envolvendo, além deste, o capital usurário e o capital bancário. O capital usurário, forma primitiva de apropriação das rendas da indústria e do comércio, era subordinado a estes, pois desempenhava uma função que de outro modo poderia ser desempenhada pelos próprios industriais e comerciantes. O capital bancário, por sua vez, nega o capital usurário na medida em que penetra na indústria tornando-se seu "fundador" e depois seu "soberano" ${ }^{\text {"182 }}$. O capital financeiro é, portanto, a síntese dos outros dois, uma vez que potencializa o desenvolvimento da indústria, ao mesmo tempo que se apodera, em um grau muitíssimo mais elevado, das riquezas produzidas por ela.

Esse movimento retrata bem a natureza dos processos financeiros, de modo que cabe retomar o significado do termo "acumulação financeira" ou "valorização financeira". Em termos marxistas, não se pode usar tal terminologia sem ressalvas ${ }^{183}$, pois a rigor a esfera financeira é incapaz de gerar e reproduzir valor e de operar autonomamente ${ }^{184}$. Marx, quando emprega o termo "acumulação do capital monetário" ou semelhante, sempre o opõe à acumulação verdadeira do capital, à “acumulação real, isto é, acréscimo da produção e

\footnotetext{
${ }^{180}$ HILFERDING, O capital financeiro, p. 227.

${ }^{181}$ Cf. Ibidem, pp. 219 e 220.

182 Termos de Hilferding.

183 Carcanholo e Sabadini também apresentam uma crítica do termo: "Em outras palavras, todo o anterior significa que, desde o ponto de vista global, a mais-valia produzida somente pode ser consumida individualmente ('consumo individual' no sentido que Marx dá), acumulada como capital produtivo ou comercial, destruída ou desperdiçada. Por isso, a expressão 'acumulação financeira da mais-valia' somente pode levar a engano; é uma afirmação que implica uma contradição em termos” - CARCANHOLO e SABADINI, "Capital fictício e lucros fictícios", p. 54.

${ }^{184}$ Em algumas passagens, Chesnais refere-se a uma "autonomia relativa" da esfera financeira, o que pode dar margem a ambigüidades. Essa questão será tratada adiante, mas já cabe citar o seguinte: "A despeito das representações fetichizadas da finança, o capital fictício engajado na Bolsa não tem a propriedade de criar novas riquezas, de criar valor. Para que a bolha financeira possa adquirir uma 'permanência', é preciso que haja uma extensão, sob diferentes formas, da dominação parasitária da finança sobre a economia real" - CHESNAIS, "A 'nova economia' (...)", p. 64 e 65.
} 
multiplicação dos meios de produção"185, de forma que "por acumulação do capital monetário em grande parte deve ser entendida apenas a acumulação desses direitos sobre a produção [ações, títulos], acumulação do preço de mercado, do valor-capital ilusório desses direitos"186.

A expressão "acumulação financeira" acaba sendo empregada de modo corriqueiro para facilitar a exposição das idéias, e aqui não será diferente. Assim, Chesnais lhe dá a seguinte definição:

$$
\begin{aligned}
& \text { Por acumulação financeira, entende-se a centralização em instituições } \\
& \text { especializadas de lucros industriais não reinvestidos e de rendas não consumidas, } \\
& \text { que têm por encargo valorizá-los sob a forma de aplicação em ativos financeiros - } \\
& \text { divisas, obrigações e ações - mantendo-os fora da produção de bens e serviços. }{ }^{187}
\end{aligned}
$$

Contudo, não se deve esquecer o que está subjacente a essa expressão. A valorização "fora da produção de bens e serviços" revela, evidentemente, a intenção dos agentes financeiros individualmente e a aparência do processo que de fato ocorre. No caso da Bolsa, a linguagem é particularmente expressiva: os investidores aí "colocam" ou "retiram" dinheiro, como se efetivamente se tratasse de uma bolsa - do rei Midas, talvez. Nela se deixa por um tempo uma soma de dinheiro, que, quando retirada, magicamente aumentou (ou diminuiu...). Ora, apesar de toda mistificação, a Bolsa é uma instituição que operacionaliza transações de compra e venda - de títulos que dão direito a uma apropriação de rendas futuras - entre agentes dois a dois. O dinheiro dos investidores não "fica" na Bolsa se reproduzindo sozinho até ser "retirado" de lá.

Assim, é possível entender a acumulação financeira de dois modos. Em alguns casos, trata-se de uma acumulação mediada por formas de renda, sendo decorrência, por conseguinte, da sacralização pura da propriedade privada. Os dividendos são uma fração da mais-valia indiretamente apropriada pelos detentores de ações ("punção da produção" da qual Chesnais fala); assim como os juros pagos pelo Estado aos possuidores de títulos públicos são fruto da arrecadação do Estado, que, por sua vez, é uma fração da mais-valia e dos salários (forma com ainda mais mediações) ${ }^{188}$. A possibilidade dessa apropriação resulta, portanto, da exploração direta de milhões de trabalhadores realizada na produção em todo o mundo. A

\footnotetext{
${ }^{185}$ MARX, O Capital, Livro III (tomo IV), cap. 26, p. 322.

${ }^{186}$ MARX, O Capital, Livro III (tomo V), cap. 29, p. 13.

${ }^{187}$ CHESNAIS, “O capital portador de juros (...)”, p. 37.

${ }^{188}$ Fora das bolsas há também formas semelhantes de apropriação por parte da finança. O crédito pessoal, por exemplo, é uma punção sobre o salário do trabalhador no seu tempo de consumo ("pós-produção"), salário este que se origina do processo de produção de mercadorias.
} 
mais-valia aí extraída e transferida para os mercados financeiros, sobretudo de países centrais, reforça a tendência altista das cotações e fornece sua base "real"189.

Todavia, do ponto de vista estritamente individual $1^{190}$, há outra forma de se "valorizar" o capital monetário que não por meio dos juros e dividendos. Para muitos agentes, parte considerável de seus ganhos na Bolsa deriva da especulação e arbitragem com ativos financeiros. Nesse caso, os ganhos (ou perdas) são oriundos da compra e venda de ativos, buscando-se lucrar com as oscilações de preço entre uma operação e outra. O interesse não reside primordialmente nos juros e dividendos que o ativo possa render, mas nos preços de mercado. Consequentemente negligencia-se as condições efetivas do empreendimento ligado ao ativo, ou seja, abstrai-se a qualidade do que está subjacente a ele.

Essas operações de especulação e arbitragem ocorrem no circuito fechado da finança. Nesse sentido, não há necessidade de transferência de riqueza da produção para a esfera financeira, de modo que os ganhos só podem ter origem em um novo arranjo da riqueza, numa nova repartição do valor que já "circula" na Bolsa. Por isso ressalta-se que essa valorização ocorre somente do ponto de vista individual: trata-se de uma ilusão de valorização, já que nenhum valor novo foi de fato produzido do ponto de vista social ${ }^{191}$. Nesses termos, a Bolsa é um jogo de soma zero e Hilferding é particularmente explícito sobre isso:

\begin{abstract}
A compra e venda desses títulos de juro é, portanto, um fenômeno puramente econômico, uma mera transposição na distribuição da propriedade privada, não exercendo influência alguma na produção ou na realização do lucro (...) São puros lucros diferenciais. Enquanto a classe capitalista como tal se apropria, sem compensação, de uma parte do trabalho do proletariado, obtendo dessa forma seu lucro, os especuladores ganham apenas uns dos outros. O prejuízo de uns é o lucro dos outros. Les affaires, c'est l'argent des autres. ${ }^{192}$
\end{abstract}

Nesse caso, a situação é análoga à que Marx comenta, ainda no início do Livro I de $O$ Capital, ao mostrar que a mais-valia não pode nascer da circulação. Em termos sociais, se as

${ }^{189}$ Cf. CHESNAIS, “A 'nova economia' (...)”, p. 67.

${ }^{190}$ Carcanholo e Sabadini apresentam a questão a partir de uma "dialética fictício/real": o capital fictício "ao mesmo tempo em que é fictício, é real. É real do ponto de vista do ato individual e isolado, no dia-a-dia do mercado, quer dizer, do ponto de vista da aparência; é a dialética fictício/real" - CARCANHOLO e SABADINI, "Capital fictício e lucros fictícios", p. 45.

${ }^{191}$ Mas mesmo que os juros/dividendos se originem de uma nova riqueza efetivamente produzida, em ambos os casos fica claro que se trata de formas de circulação da mais-valia, nunca de sua produção, ou seja, referem-se à repartição do valor socialmente produzido, mas não acrescentam novo valor.

${ }^{192}$ HILFERDING, O capital financeiro, p. 139. 
mercadorias forem vendidas acima de seu valor, não há ganho efetivo para ninguém, pois o que se lucra na venda se perderá na compra, e o valor global continuará o mesmo. Ao se passar para casos individuais, é possível obter vantagem vendendo mais caro, mas aí já não se está no âmbito da troca de equivalentes, mas da fraude. Não há criação de valor ${ }^{193}$, mas uma nova repartição em favor de uma das partes:

Depois da troca ["fraudulenta"], temos o mesmo valor global de 90 libras esterlinas.

$\mathrm{O}$ valor circulante não aumentou um único átomo, a sua repartição entre $A$ e $B$ é que se modificou. De um lado aparece como mais-valia o que do outro é menosvalia, de um lado como plus, do outro como minus. A mesma mudança teria ocorrido se $A$, sem a forma dissimuladora da troca [ou da transação financeira na Bolsa - I.L.], tivesse roubado 10 libras esterlinas diretamente de B. A soma dos valores circulantes não pode evidentemente ser aumentada por meio de nenhuma mudança em sua distribuição. ${ }^{194}$

Uma grande diferença no caso dos mercados financeiros é que o caráter fictício dos ativos solapa os parâmetros para a determinação dos preços, permitindo, assim, distorções muito maiores e, consequentemente, vultosas apropriações de valor por meio desse mecanismo.

Assim, esse segundo modo de se conceber a acumulação financeira implica, na realidade, não entendê-la como tal - enquanto concentração propriamente dita -, mas como centralização do capital monetário. Se do ponto de vista do capitalista financeiro individual o aumento de sua riqueza oriundo de especulações e arbitragens parece uma frutificação do seu capital, ele na verdade não passa de apropriação do valor possuído por outrem. Como foi dito, na Bolsa só há compras e vendas, o que é investido não fica lá, e por isso esse tipo de ganho só pode vir dessas operações. Essa forma de apropriação de riqueza é potencialmente muito elevada, já que é a repartição de um valor já constituído e, portanto, não se detém nos limites da acumulação do capital industrial ${ }^{195}$. Essa é uma característica própria da centralização, tal qual definida por Marx:

${ }^{193}$ Contemporaneamente, a ilusão de uma criação efetiva de valor pode se dar por meio de esquemas tais como o da "pirâmide" (de Madoff, por exemplo, em que os aportes de novos investidores eram empregados para remunerar os antigos. Contudo, tão logo o aporte de novos recursos cesse ou que um número elevado de investidores resolva retirar seu dinheiro ao mesmo tempo, a pirâmide desmorona como um castelo de cartas).

${ }^{194}$ MARX, O Capital, Livro I (tomo I), cap. 4, p. 136.

195 Não se deve esquecer que os juros e dividendos ainda precisam "respeitar" o ritmo da produção real. Embora os acionistas possam pressionar pelo encurtamento dos prazos de retorno dos investimentos - gerando grandes conseqüências, como mencionado -, eles ainda precisam aguardar o ciclo produtivo se completar para receber sua parte. 
Esse processo (...) pressupõe apenas divisão alterada dos capitais já existentes e em funcionamento, seu campo de ação não estando, portanto, limitado pelo crescimento absoluto da riqueza social ou pelos limites absolutos da acumulação. O capital se expande aqui numa mão, até atingir grandes massas, porque acolá ele é perdido por muitas mãos. É a centralização propriamente dita, distinguindo-se da acumulação e da concentração. ${ }^{196}$

Quanto mais recursos são investidos nas Bolsas e quanto mais os mercados se interligam e se tornam "líquidos", mais poderosos se tornam esses mecanismos de centralização do capital monetário. Nos mercados de derivativos, nos quais atualmente há um volume muito maior de operações ${ }^{197}$, são tão somente os processos de centralização financeira que intervêm, pois só o rearranjo de riqueza é possível. Atualmente, existe uma miríade de produtos financeiros, mas os contratos "clássicos" de derivativos (opção, a termo, futuro e swap sobre commodities e sobre índices como juros e câmbio) já permitem compreender que é a centralização o processo em questão, dado que todos esses contratos são uma espécie de "aposta" no preço de um bem em certa data.

No contrato futuro, por exemplo, o "perdedor" paga ao "ganhador" a diferença entre o preço acordado e o preço efetivo do bem no dia de vencimento do contrato. A única maisvalia que pode ser apropriada nesse caso, quando há, não se apresenta como renda (juros/dividendos), ou seja, como direito de propriedade sobre os frutos de alguma produção,

${ }^{196}$ MARX, O Capital, Livro I (tomo II), cap. 23, p. 196.

197 Além dos dados da Introdução, apresenta-se a tabela abaixo, referente ao Brasil, mas que não está longe da realidade dos EUA e de outros países com praças financeiras desenvolvidas. Ela mostra que o volume de transações destes é mais de 20 vezes maior que a do mercado à vista. (Lembrando que os dados para o mercado à vista são de volumes financeiros efetivamente transacionados, ao passo que no mercado de derivativos, por seu modo peculiar de funcionamento, o valor dos contratos é muito superior ao que é realmente circulado entre os agentes. Ainda assim, a relação entre os dois dados surpreende).

\begin{tabular}{|l|c|c|}
\hline \multicolumn{2}{|c|}{ Tabela 2 - Volumes Financeiros Negociados na BM\&FBOVESPA (R\$) } \\
\hline & $\begin{array}{c}\text { Segmento Bovespa } \\
\text { [à vista; valor efetivo] }\end{array}$ & $\begin{array}{c}\text { Segmento BM\&F } \\
\text { [derivativos; valor nocional] }\end{array}$ \\
\hline $\mathbf{2 0 0 8}$ & 1,37 trilhão & 28,01 trilhões \\
\hline $\mathbf{2 0 0 9}$ & 1,30 trilhão & 26,78 trilhões \\
\hline \multicolumn{2}{|l}{ Fonte: BM\&FBOVESPA } \\
\hline
\end{tabular}

Esse dado é tanto mais impressionante quando se considera que a grande maioria dos ativos atualmente negociados na BM\&FBOVESPA são produtos financeiros (moeda, juros, etc.). Embora os mercados futuros não sejam recentes (a Chicago Board of Trade data de 1848, por exemplo), contratos de derivativos baseados em ativos financeiros só surgem a partir dos anos 1970. 
e, portanto, como mais-valia, mas é o substrato material do pagamento pela perda da "aposta" - no caso, por exemplo, de uma empresa que paga o que perdeu do seu próprio lucro ${ }^{198}$.

Isso sem falar nos processos efetivos de centralização do capital (industrial) que ocorrem através da bolsa. Muitos das operações de fusão e aquisição de empresas ocorrem pela compra em massa das ações. Hilferding mostra que, com as sociedades por ações, uma mesma quantidade de capital está em condições de controlar um número maior de empresas, uma vez que ele não precisa comprá-las por inteiro, mas apenas deter a maioria (às vezes relativa e não necessariamente absoluta) das ações. Embora se abra mão dos dividendos que se receberia detendo a totalidade das ações, ganha-se ao obter controle sobre capital alheio: o domínio da empresa "é importantíssimo para influenciar o movimento de compra e venda das ações na bolsa" $" 199$.

Porém, além disso, controlando determinadas empresas é possível comprar ou criar outras, formando o que Hilferding chama de "sistema de sociedades interdependentes". A cada operação, através da emissão de novas ações para capitalizar as empresas criadas ou ampliar as já existentes, o capital próprio original vai se assenhoreando de somas cada vez mais elevadas de capital alheio. De modo que "com o desenvolvimento do sistema acionário acaba se formando uma técnica financeira própria, cuja missão é a de assegurar ao menor capital próprio possível o domínio sobre o maior capital alheio possível"200. Atualmente, muitos desses capitais originais pertencem a investidores institucionais, que acabam controlando outros capitais menores, muitos dos quais, pela sua pequena monta, talvez só

\footnotetext{
${ }^{198}$ Para aqueles que ainda possuem a ilusão de que a Bolsa tem a função precípua de fomentar a produção, basta observar uma prática recente no mercado acionário brasileiro: o aluguel de ações. Esse mecanismo não pode ter outra utilidade efetiva a não ser a especulação ou operações fictícias. Isso porque o dono da ação, além do "aluguel", continua a receber dividendos e outros rendimentos referentes às suas ações enquanto elas estão alugadas. Se aquele que toma emprestado não participa dos rendimentos das ações, só pode ganhar com transações puramente financeiras, no circuito fechado das Bolsas: "Os tomadores, em geral administradores de carteiras, tomam ações emprestadas para dar lastro às operações de arbitragem (compra e venda simultânea de ações, em geral, com pequenas margens)" - BM\&FBOVESPA, "Um mercado crescente para elevar o lucro das carteiras".

Esse tipo de "lastro", altamente fictício, mostra sua impotência em desempenhar tal papel precisamente nos momentos de crise, quando mais se precisaria dele. Além disso, o aluguel de ações ainda presta um serviço à finança: "as corretoras ganham com o ingresso de novos clientes" - Ibidem Sobre o papel atual desempenhado pela Bolsa, ver também LORDON, "Fechar a Bolsa?"

${ }^{199}$ HILFERDING, $O$ capital financeiro, p. 122.

${ }^{200}$ Ibidem, p. 123.
} 
tenham se tornado capital monetário precisamente por causa da oportunidade aberta pelos mercados financeiros ${ }^{201}$.

Assim, como sintetiza Chesnais, "uma das conseqüências do desenvolvimento do mercado bursátil é acelerar o processo de centralização e concentração do capital e também de criar 'atalhos' para o acesso à propriedade dos meios de produção" ${ }^{202}$. Esses "atalhos" são, na realidade, meios de formação ou incremento de propriedade paralelos aos processos de concentração na indústria. Os capitalistas no controle de várias empresas têm muito a ganhar com isso, já que possuem uma visão muito mais acurada da real situação das mesmas e do mercado em geral, além de terem maiores condições de influenciar o rumo das cotações na Bolsa. Ademais, nesta os ganhos são virtualmente "ilimitados": se no empréstimo há uma taxa de juros e um prazo acordados, no funcionamento da Bolsa, ao contrário, não há limites prédefinidos para a oscilação de preços das ações e, portanto, para os ganhos com especulação e $\operatorname{arbitragem}^{203}$.

Os processos de "valorização financeira" estão, assim, na base do que Chesnais denominou "autonomia relativa da esfera financeira"204. Como essa expressão é equívoca, se faz necessário compreender o que ela realmente significa.

Em primeiro lugar, cabem alguns comentários sobre as críticas que Klagsbrunn faz a Chesnais a esse respeito. Afirma o autor:

Desde o início a separação algo mecânica das esferas produtiva e financeira levava a uma incompreensão da interdependência entre as duas, que culminou na dominação externa, formal, da primeira pela segunda. Deste modo, todos os intentos da escola da mundialização vão no sentido de denunciar os efeitos negativos da esfera financeira e as propostas de política econômica vão na direção

\footnotetext{
201 "Para efetuar a concentração dos capitais de uma empresa, a sociedade anônima compõe seu capital juntando porções individuais de capital que, separadamente, talvez sejam pequenas demais para desempenhar uma função industrial" - HILFERDING, O capital financeiro, p. 124.

${ }^{202}$ CHESNAIS, "La prééminence de la finance (...)", p. 88.

203 "Há várias diferenças entre a aplicação sob a forma de empréstimos e em ações. No segundo caso, a remuneração da aplicação é indeterminada, o "juro para o capital-dinheiro colocado à disposição sob a forma de ação não é fixado de antemão"” - CHESNAIS, "La prééminence de la finance (...)", p. 94 (a citação entre aspas é tirada de HILFERDING, Le capital financier).

${ }^{204}$ CHESNAIS, "O capital portador de juros (...)”, p. 45.
} 
de limitar sua atuação. Com isto, propõe antes de tudo limitar a especulação como um apêndice indesejado da esfera financeira. ${ }^{205}$

Apesar da ausência de uma posição explícita a esse respeito na obra de Chesnais, não parece haver propriamente uma "incompreensão" do autor, mas uma ambigüidade em sua exposição. Conforme citações aqui reproduzidas, não cabe supor que ele conceba uma "separação mecânica" ou uma autonomia de fato da esfera financeira. A questão talvez esteja, primeiramente, no fato de ele não explicitar quando sua análise está tratando da aparência de um fenômeno ou processo - nesse caso o termo "autonomia" não seria problemático, pois exprime a forma pela qual os agentes apreendem a realidade - ou do que de fato está ocorrendo. Neste caso, realmente o termo leva a enganos e é impreciso.

Da mesma forma, Chesnais transita - nem sempre anunciando devidamente - entre uma análise da circulação e do funcionamento do capital nas suas diferentes formas e uma visão mais "sociológica" (atores sociais que representam ou servem de suporte às diferentes formas do capital) ${ }^{206}$. Assim, os "interesses da finança" que se impõem de modo "autônomo" (externo) à produção não são interesses de um capital portador de juros abstrato, separado da produção, mas da classe de capitalistas financeiros. Classe esta que não necessariamente penetra (e normalmente não o faz) na essência do capitalismo e, por isso, não apreende as relações de dependência e contradição existentes entre as esferas financeira e produtiva. Como defendia Marx, se aparência e essência coincidissem, toda ciência seria desnecessária.

Além disso, é verdade que o foco estrito na dinâmica do capital portador de juros pode por vezes ofuscar suas estreitas relações com os demais capitais e o papel destes (sobretudo o industrial) no capitalismo, inclusive suas contradições. Causa-se, assim, uma falsa percepção de que o capital financeiro é o responsável por todos os "males" do capitalismo contemporâneo. Se Chesnais fosse mais claro nesse ponto, poderia evitar a impressão reformista e maniqueísta de um capital financeiro "mau”, que só parasita a economia, e um capital industrial mais "bonzinho", que pelo menos produz bens de que precisamos e gera emprego $^{207}$.

${ }^{205}$ KLAGSBRUNN, "Mundialização x Globalização e o papel das Finanças no capitalismo contemporâneo", p. 1.

${ }^{206}$ Viu-se que essa posição está presente no próprio Marx.

${ }^{207}$ Esse é de certa forma o tom, por exemplo, do texto de Ladislau Dowbor. Apesar de crítico na análise da crise, o autor cai nessa distinção descabida. Há uma mostra disso na seguinte passagem: "Gera-se uma clara clivagem entre os que trazem inovações tecnológicas e produzem bens e serviços socialmente úteis - os engenheiros do processo, digamos assim - e o sistema de intermediários financeiros, comerciais e advocatícios que se apropriam 
Nesse sentido, uma concepção dialética da questão deve aceitar o fato de que as finanças, por mais que não possam de fato se autonomizar da produção, são impelidas por sua própria lógica e dinâmica a se comportarem como se o pudessem, e assim efetivamente se comportam. Donde as crises e efeitos contraditórios desse processo que afetam o capital em geral e não apenas uma forma específica dele. Do mesmo modo, embora seja fruto da mesma ambigüidade de Chesnais (e talvez de sua defesa da taxa Tobin ${ }^{208}$ ), não se pode pensar que para ele a solução da questão se resumiria a uma simples limitação da especulação. Chesnais enfatiza que, no regime financeirizado, novas contradições se combinam com as já existentes de todo modo no capitalismo ${ }^{209}$.

Eleutério Prado, por sua vez, critica precisamente a noção de "autonomia relativa", cabendo concordar que a expressão empregada por Chesnais é infeliz:

A expressão 'autonomia relativa da esfera financeira em relação à produção' também não é rigorosa, já que não se trata de uma questão de relatividade, mas de contradição: a autonomia da esfera financeira vem a ser negada pela essência da relação de capital, a qual põe objetivamente a não autonomia da esfera financeira em relação à produção. ${ }^{210}$

Quanto a isso, cabe observar, primeiramente, que no primeiro sentido que se atribuiu à expressão "valorização financeira", mostrou-se que a punção de riquezas rumo à esfera financeira pode ocorrer não só diretamente sobre a mais-valia, mas também através de inúmeros circuitos indiretos, tais como impostos (dívida pública) e salários (crédito ao consumidor $)^{211}$. Nisso residiria uma das dimensões da "autonomia" da esfera financeira. Contudo, ela é relativizada pelo fato de que, levando em consideração o sistema como um todo (o capital social), o capital portador de juros não pode existir sem produção de

do excedente e deformam a orientação do conjunto" - Cf. DOWBOR, "A crise financeira sem mistérios. Convergência dos dramas econômicos, sociais e ambientais".

${ }^{208}$ A proposta do professor americano James Tobin de criar um imposto sobre o capital financeiro, taxando as operações de câmbio e revertendo o dinheiro para políticas sociais. Para mais detalhes sobre a defesa de Chesnais dessa taxa, ver CHESNAIS, Tobin or not Tobin?.

${ }^{209}$ Cf. CHESNAIS, "O capital portador de juros(...)", p. 60.

${ }^{210}$ PRADO, "Resenha de 'A finança mundializada"”, p. 221.

${ }^{211}$ Essas fontes "indiretas" de apropriação de valor, que não passam pelos processos "clássicos" de extração de mais-valia, podem ser aproximados dos processos que estão na raiz do que Harvey denominou de "acumulação por espoliação". E as preocupações de Chesnais parecem ser solidárias às de Harvey quando este se pergunta "como, quando e por que a acumulação por espoliação sai dessa condição clandestina e se torna a forma dominante de acumulação com respeito à reprodução expandida?” - HARVEY, O novo imperialismo, p. 127. 
mercadorias $^{212}$, já que é a riqueza da produção que necessariamente alimenta os mercados financeiros.

O outro sentido atribuído à "valorização financeira" refere-se ao circuito fechado das transações nos mercados financeiros e à especulação, à arbitragem e a todas as formas de aumento fictício dos preços dos ativos. Esse tipo de processo ganhou importância no capitalismo contemporâneo devido ao suporte institucional que recebe, e é capaz de manter as operações fictícias por um tempo às vezes bastante prolongado "imunes" à esfera produtiva. Entre as conseqüências dessa situação podem-se citar a gravidade que as crises têm atingido: o "acerto de contas" com o real é potencialmente muito drástico devido aos abismos criados entre as duas esferas nesse período de "incomunicabilidade".

É principalmente esse tipo de dinâmica que Chesnais denomina de "autonomia relativa da finança": há certa autonomia dos processos fictícios no interior dos mercados financeiros, em que os preços dos ativos podem variar muito a partir de dinâmicas próprias a esses mercados ${ }^{213}$, levando a inúmeros rearranjos da riqueza. Contudo, em última instância, somente o âmbito da produção pode lastrear as operações, a esfera financeira não podendo prescindir dele. Por isso, essa autonomia é precária e de certa forma ilusória. Chesnais, apesar de passagens ambíguas, não advoga uma autonomia de fato da finança nem concebe a

${ }^{212}$ Como explica Teixeira, “o capital portador de juros é uma redistribuição da renda que não precisa ser, necessariamente, da mais-valia", e mais adiante: “[mas] ele não é autônomo, porque, na base da produção capitalista, o capital portador de juros só pode existir porque existe o capital, o movimento D-M-D'” TEIXEIRA, Dependência, desenvolvimento e dominância financeira, pp. 84 e 85 respectivamente.

${ }^{213}$ Klagsbrunn defende que os preços das ações, embora possam variar, estão fundamentalmente atrelados às expectativas de lucros futuros da empresa, criticando, assim, as concepções "idealistas" ou "psicológicas" que Chesnais e outros autores possuiriam ao se afastarem do "caminho materialista assinalado por Marx" (Cf. KLAGSBRUNN, "Mundialização x Globalização e o papel das Finanças no capitalismo contemporâneo", p. 12). Contudo, embora o preço das ações possua como um de seus fatores determinantes as expectativas de lucros futuros, deve-se levar em conta que na prática muitas vezes é difícil fazer esse cálculo. Dependendo do tipo de empresa, os resultados e os próprios cálculos podem ser muito díspares. Além disso, não se pode de modo algum desprezar a "euforia" que determinados mercados ou empresas são capazes de gerar nas Bolsas, distorcendo em muito as cotações. Um exemplo que ilustra articuladamente essas duas ressalvas ao argumento de Klagsbrunn é o da crise financeira de 2000 nos EUA, ligada ao setor de telecomunicações e alta tecnologia. Não se trata, assim, de recusar os fundamentos materialistas. Estes podem determinar uma valorização "real" das ações (pelo crescimento da empresa), bem como limitar a valorização das ações e levar ao estouro da bolha em algum momento. É Klagsbrunn que talvez abstraia a ação dos atores sociais e confunda o capital real e o fictício, o "valor" e o "preço", e postule que este não possa variar especulativamente (inclusive se apoiando em premissas da economia ortodoxa, de transparência e simetria de informações). Não se pode negar certos fenômenos (sobretudo de curto prazo) em nome de uma pretensa fidelidade a princípios teóricos (aliás, em detrimento de outros).

A esse respeito, Harvey também aponta, em relação à oferta de capital portador de juros, a importância de "estados psicológicos": "as dívidas e o capital fictício podem começar a circular como capital de empréstimo na medida em que todos tenham fé na saúde da economia - estados psicológicos acerca das expectativas são, pelo menos no curto prazo, importantes para esse processo" - HARVEY, Limits to Capital, p. 298. 
dominância financeira como uma esfera financeira que produz valor prescindindo da esfera produtiva.

As ambigüidades talvez derivem do fato de que Chesnais parece querer escapar tanto à idéia fetichista de uma autonomia total da esfera financeira como ao diagnóstico de que esta não passa de uma ilusão mistificadora e, portanto, destituída de importância para a compreensão do capitalismo atual. A fim de não restar dúvidas sobre sua posição, cita-se o que ele escreveu ainda em meados dos anos 1990:

Os termos 'autonomia' e 'autonomização' etc. devem ser utilizados com muito cuidado. É verdade que parte elevadíssima das transações financeiras verifica-se no circuito fechado formado pelas relações financeiras especializadas. Mas isso não quer dizer que não existam vínculos muito fortes, e sobretudo de grande alcance econômico e social, entre a esfera de produção e circulação e a das finanças. A esfera financeira [sic - O correto seria "produtiva" - I.L.] nutre-se da riqueza criada pelo investimento e mobilização de uma força de trabalho de múltiplas qualificações. Uma parte, hoje elevada, dessa riqueza é captada ou canalizada em proveito da esfera financeira, e transferida para esta. Somente depois de ocorrer essa transferência é que podem ter lugar, dentro do circuito fechado da esfera financeira, vários processos de valorização, em boa parte fictícios, que inflam ainda mais o montante nominal dos ativos financeiros. ${ }^{214}$

A ilusão de autonomia é, portanto, reforçada no capitalismo financeirizado precisamente porque a esfera financeira cresce mais rapidamente do que a produção de mercadorias, "inchando-se" 215 . Ela tanto se alimenta direta e indiretamente da riqueza originada na produção - por meio inclusive dos crescentes e contínuos aportes efetuados por pessoas físicas, empresas e outras instituições que investem nos mercados financeiros ${ }^{216}$ como possibilita a inflação dos ativos financeiros por meio de processos fictícios, que a especulação impulsiona a níveis elevados.

\footnotetext{
${ }^{214}$ CHESNAIS, A mundialização do capital, p. 246.

215 Ver dados fornecidos na Introdução e em PLIHON, "Desequilíbrios mundiais e instabilidade financeira: a responsabilidade das políticas liberais. Um ponto de vista keynesiano”, cap. 4 (sobretudo pp. 112 e 113).

${ }^{216}$ Chesnais destaca o papel fundamental que aí desempenha a dívida pública: "Trata-se de $20 \%$ do orçamento dos principais países e de vários pontos dos seus PIBs, que são transferidos anualmente para a esfera financeira. Parte disso assume então a forma de rendimentos financeiros, dos quais vivem camadas sociais rentistas" CHESNAIS, op. cit., p. 15.
} 
Essa hipertrofia da finança possui conseqüências importantes no tocante às crises econômicas, já que a solução destas passa, a princípio $^{217}$, pela diminuição drástica do abismo existente entre as cotações em vigor dos ativos financeiros e sua contrapartida real. Por isso Chesnais afirma que:

A acumulação de capital fictício, cujos títulos são objeto de transações em mercados muito particulares situados muito longe da produção, é igualmente portadora de crises financeiras, e isso de maneira quase automática. Essas reapareceram, então, com a reconstituição desse capital. ${ }^{218}$

Nesse sentido, para definir o cenário atual do capitalismo no que se refere às crises financeiras, Chesnais utiliza o termo "fragilidade sistêmica". Embora o funcionamento do capitalismo em todas as suas fases leve necessariamente a crises mais ou menos freqüentes, o intuito do emprego dessa noção é mostrar que atualmente as crises não são apenas cíclicas, mas muito recorrentes e talvez menos previsíveis (ou mais abruptas) por ocorrerem em um contexto de instabilidade econômica crônica, em que as condições para a ocorrência de crises estão dadas a todo momento ${ }^{219}$. A fragilidade sistêmica refere-se, portanto, a dois aspectos:

Em primeiro lugar, trata-se de expressar a nova relação existente entre a produção e o intercâmbio, de um lado, e a esfera financeira, de outro, relação marcada pela multiplicação de abalos financeiros, não sendo possível vinculá-los de forma imediata, à conjuntura econômica. Mas o termo serve também para designar o fato de que o sistema financeiro atingiu tais dimensões e tal complexidade, em função de sua hipertrofia de crescimento, que estas podem gerar, por si mesmas, uma 'fragilidade sistêmica', que se manifesta no comportamento dos principais operadores". 220

Há diversos fatores que compõem essa situação de fragilidade sistêmica.

\footnotetext{
217 "A princípio", pois as intervenções de governos e instituições internacionais no sentido de injetar liquidez nos mercados durante as crises evitam a "desinflação" completa dos ativos, conservando a ficção (ainda que em patamares mais baixos).

${ }^{218}$ CHESNAIS, "La prééminence de la finance (...)", p. 115.

219 Jorge Grespan defende que as crises em Marx são uma "necessidade relativa”, e não absoluta, na medida em que o funcionamento do capitalismo possui tendência inerente a gerar crises (potencialmente a qualquer momento), mas não é possível determinar de antemão quando e como (e no limite se de fato) as crises vão ocorrer - Cf. GRESPAN, $O$ negativo do capital. A queda da taxa de lucro é uma tendência que possui suas contra-tendências, de modo que o movimento do capital é um processo em aberto. Isto posto, o regime financeirizado parece representar uma inflexão nessa idéia, na medida em que novas variáveis agem ampliando a tendência à crise. A atual enorme expansão do capital fictício leva à conclusão de que é impossível a realização material de todos os ativos financeiros em circulação, ou seja, que a crise já está, de alguma forma, pressuposta. Desse modo, a inflexão talvez seja que, embora ainda não se possa determinar quando, onde e como a crise ocorrerá (ainda é uma necessidade relativa), a desproporção entre capital fictício e economia real é tal que se poderia afirmar que não há como a crise não vir a acontecer, ou mesmo que a crise já está, de alguma forma, em curso.

${ }^{220}$ CHESNAIS, "Mundialização financeira e vulnerabilidade sistêmica”, p. 255.
} 
Um deles é a insaciabilidade da finança, que se constitui na "causa primordial dessas crises" 221 . Por um lado, e a governança corporativa tem aí papel crucial, ela pressiona as empresas a elevar ao máximo a fração do lucro paga como dividendos aos acionistas e a operar cada vez mais no curto prazo. A médio e longo prazos, portanto, isso se traduz em uma diminuição do lucro reinvestido na produção e, sobretudo, dos investimentos de longo prazo $^{222}$ (essenciais para a manutenção dos níveis de crescimento econômico). Consequentemente, estreita-se a própria base material sobre a qual os lucros financeiros assentam. Por outro lado, somas crescentes, inclusive os próprios dividendos e outros rendimentos recebidos via esfera financeira, são alocadas ou realocadas nos circuitos financeiros, atraídas pelo fetiche da valorização do circuito D-D', aumentando, assim, as dimensões da esfera financeira.

Em decorrência disso, o quadro atual é de um "volume extremamente elevado dos créditos sobre a produção futura que os possuidores de ativos financeiros consideram poder pretender" ${ }^{, 23}$. Enquanto se está numa fase de crescimento, a bolha aumenta e o fetiche da valorização financeira parece se realizar. Todos parecem ganhar com a Bolsa e se beneficiar do chamado "efeito riqueza". Assim que o cenário muda, ocorre o estouro da bolha. Os ativos perdem valor rapidamente, mostrando que muitos deles não tinham condições de realizar as expectativas. O que torna difícil prever quando as crises serão desencadeadas é precisamente o grande volume de capital fictício constantemente presente na economia e, portanto, também a dificuldade de avaliar os preços dos ativos.

Além disso, embora nas operações da Bolsa haja um jogo de soma zero, isso não quer dizer que as compensações se dêem simultaneamente. Em $O$ Capital $^{224}$, Marx menciona a terceira determinação do dinheiro, a de "meio de pagamento". Além ser medida do valor (funcionando como padrão de preços) e meio de circulação propriamente dito (mediador efetivo das trocas), ele se autonomiza da própria circulação e passa a ser um intermediário “ideal" das transações. Esta determinação possibilita o surgimento do próprio sistema de crédito pela decalagem temporal entre a troca das mercadorias e seu pagamento, já que o

\footnotetext{
221 "A causa primordial dessas crises reside na diferença entre o montante, sempre mais elevado, dos direitos sobre a produção em curso e futura e a capacidade efetiva do capital empregado na produção de honrá-los (...) $\mathrm{Na}$ raiz das crises financeiras se encontra, então, a propensão do capital regido pelo movimento D - D' a demandar da economia "mais do que ela pode"” - CHESNAIS, "La prééminence de la finance (...)", pp. 115-116 (itálico no original).

${ }^{222}$ Chesnais mostra, através de um gráfico, o declínio contínuo do investimento nos países da OCDE entre 1960 e os anos 1990 - CHESNAIS, "Mundialização financeira e vulnerabilidade sistêmica", p. 262.

${ }^{223}$ CHESNAIS, "O capital portador de juros (...)", p. 62.

${ }^{224}$ Cf. MARX, O Capital, Livro I (tomo I), cap. 3.
} 
dinheiro não precisa estar presente. Do mesmo modo, diversas operações podem ocorrer na Bolsa e só se compensarem mais tarde, sobretudo porque se baseiam no capital fictício. A bolha e seu boom são duas faces do mesmo movimento, mas que ocorrem em momentos distintos: na primeira, todos parecem estar ganhando, ao passo que na segunda a perda parece generalizada $^{225}$.

Outro fator constitutivo da fragilidade sistêmica está ligado à própria mundialização e à desintermediação financeira que a acompanha. Em um cenário de grande concorrência entre os grandes grupos industriais e entre os próprios agentes da finança, adotam-se comportamentos cada vez mais arriscados. Mesmo (ou inclusive) os bancos - que têm uma importância fundamental na oferta de crédito, sobretudo em momentos de crise - acabam assumindo posições ousadas no jogo da finança ${ }^{226}$. Eles precisam compensar as perdas decorrentes da desintermediação, que os enfraqueceram face às alternativas de capitalização oferecidas pelos mercados financeiros. De modo semelhante, os administradores dos grandes grupos adotam estratégias agressivas, buscando auferir lucros extras por meio dos mercados financeiros ${ }^{227}$.

O aumento dos riscos das operações e especulações se torna irracional também por outros motivos, já que em certos momentos os operadores financeiros têm consciência de que os preços dos ativos estão inflados, que há uma "exuberância irracional" 228 , mas continuam

\footnotetext{
${ }^{225}$ Nas operações de compra e venda na Bolsa, um ganha e outro perde, mas isso não ocorre necessariamente na mesma operação, é um resultado global. Considere-se um exemplo simples: $A$ compra uma ação por 20 . Um mês depois, devido à valorização da ação, ele a vende para $B$ por 40 (ganhando 20). Se $B$, passado algum tempo, vender para $C$ por 60 , também ganha 20 . Se $C$ vender a $D$ por 80 , ele também ganhou 20. Suponha-se que toda essa "valorização" da ação seja fictícia e tenha se dado pela formação de uma bolha. Se uma crise sobrevier e $D$ for obrigado a vender a ação que comprou por 80 pelo preço novamente de 20 , foi ele o único que perdeu e que "sustentou" o ganho de $A$, de $B$ e de $C$ (e não $C$ o de $B$, e $B$ o de $A$ ).

${ }^{226}$ Esse fato ficou particularmente claro recentemente, com os inúmeros bancos que alavancaram demais suas operações e acabaram falindo com a chegada da crise. No caso específico dos bancos, essa alavancagem normalmente significou um desrespeito aos Acordos de Basiléia, o que não é algo de agora (Cf. GUTTMANN, "Basiléia II: uma nova estrutura de regulação para a atividade bancária global"). Isso sem contar o chamado shadow banking system, ou seja, um conjunto de instituições não bancárias (e, portanto, não sujeitas as mesmas regras dos bancos) que passam a ser também importantes fornecedores de crédito.

${ }^{227}$ Como já mencionado, só o fato de os administradores não serem os donos efetivos do capital já estimula de alguma forma comportamentos mais arriscados. Isso ainda se combina com as pressões próprias à competitividade.

Embora muitas operações financeiras tenham se incorporado ao cotidiano das empresas e tenham o objetivo de diminuir os riscos inerentes à atividade produtiva, o exemplo nada singular da Sadia mostra que tais atividades, antes auxiliares da produção, tornam-se fontes adicionais de lucro (às vezes mais importantes que a de produção). Os mais de R \$ 2,5 bilhões que a Sadia perdeu com os investimentos em derivativos de câmbio antes de ser comprada pela Perdigão revela que o montante investido ultrapassava em muito as necessidades de "hedge cambial" para garantir as exportações, configurando-se pura atividade especulativa - Cf. PORTAL EXAME, Sadia perde cerca de $R \$ 2,5$ bi com câmbio em 2008, diz Brascan.

${ }^{228}$ Célebre expressão de Alan Greenspan, quando era presidente do FED, sobre a situação inflacionada dos mercados financeiros antes da crise financeira do início dos anos 2000 nos EUA. É impossível que não se
} 
investindo. Pois o que importa não é a realidade dos fundamentos econômicos, e sim o momento certo de "sair" da Bolsa (ou seja, logo antes da bolha estourar ou dos preços começarem a cair).

Dada a interligação dos diferentes mercados financeiros entre si, resultante da abertura financeira generalizada, em geral as crises se propagam de um mercado a outro e, dependendo da gravidade, de um país para outro. Isso é especialmente preocupante devido, por exemplo, à estrutura dos mercados de derivativos. Neles, as transações só se efetivam no futuro, o que aumenta o perigo dos desencontros entre o "real" e o "esperado". Mais do que isso, dadas as garantias oferecidas pelas Bolsas e suas câmaras de compensação, muitas operações não requerem que o comprador deposite efetivamente o valor (ou não a integralidade dele) dos contratos adquiridos, bastando apenas que ele pague as eventuais variações de preço ${ }^{229}$. Essa operação permite alto grau de alavancagem, ou seja, um investimento muito além das possibilidades efetivas do agente naquele momento. Isso significa que, além de aumentar a ficção nos mercados (investiu-se um valor que não se tem), contribuindo para a instabilidade financeira, as perdas também são potencializadas no momento de um revés ou crise.

A generalização das políticas de taxas de câmbio flutuantes é outro fator crucial no desencadeamento das crises devido à importância que a moeda tem para os países, à magnitude dos mercados de câmbio e ao fato deste ter sido o primeiro segmento a entrar na mundialização financeira e continuar a abrigar um número elevado de operações. A volatilidade do câmbio cria, portanto, tensões recorrentes entre os capitalistas e leva, entre outras coisas, a um processo auto-alimentador. As empresas são impelidas a realizar operações de "hedge cambial" (que talvez nem precisassem ou em quantidade excessiva) pelo temor de grandes oscilações. Isso, por sua vez, significa injeção adicional de dinheiro nos mercados de câmbio contribuindo para reforçar a instabilidade.

percebesse a discrepância contida na seguinte situação: "No início de 1994, o índice Dow Jones estava em 3.600 pontos, e no início de 2000, estava em 11.675 pontos, um crescimento de 225\%, e, no mesmo período, os lucros das ações cotadas na bolsa de Nova York cresceram não mais do que 60\%" - PAULANI, "A crise do regime de acumulação (...)", nota 17.

${ }^{229}$ Para noções básicas sobre derivativos, consultar a seguinte publicação muito didática: BM\&FBOVESPA, Mercados Derivativos. Ela mostra como certos mercados de derivativos são muito antigos e qual a lógica que estaria por trás de seu surgimento: a garantia de um preço satisfatório para comprador e vendedor de uma commodity numa transação a ocorrer futuramente. Os especuladores teriam, então, uma função importante nesses mercados: a de fornecer liquidez. "Só" se esquece de dizer que, nas condições atuais, o que inclui a predominância esmagadora de transações com derivativos financeiros (moeda, juros, etc.), essa situação já deixou de ser a raison d'être da Bolsa e a especulação se tornou a regra. Citando de forma livre o que disse um professor da FEA/USP em uma aula: nesses mercados, compra-se o que não se quer e vende-se o que não se tem. 
Chesnais ressalta ainda que as principais crises nos países emergentes - onde a vulnerabilidade é maior que nos países centrais, devido à menor liquidez de seus mercados e à maior desconfiança dos investidores - ocorridas durante os anos 1990 se iniciaram por uma desvalorização da moeda nacional (inevitável devido aos déficits comerciais), que depois se espraiou para outros mercados e setores. Em razão da desregulamentação dos mercados financeiros e de sua conseqüente interligação:

As crises financeiras assumiram frequentemente, desde o início da liberalização, a forma de 'crises gêmeas', quer dizer, crises simultâneas em um ou vários mercados financeiros (de câmbio, de bônus do Tesouro, de ações) e no sistema bancário, que em seguida, de forma brutal, propaga a crise financeira pelo sistema produtivo. ${ }^{230}$

Essa dinâmica revela outra especificidade do atual regime financeirizado, a saber, o aparecimento e a ocorrência reiterada de "crises financeiras "autênticas",231. Esta expressão significa que, embora a origem das crises financeiras esteja sempre ligada à base produtiva, ou melhor, ao descompasso entre as esferas financeira e produtiva (e à contradição entre as duas esferas na valorização do capital), essas crises financeiras autênticas parecem ser desencadeadas na esfera financeira e se propagar para a esfera produtiva ${ }^{232}$. Ao contrário das crises "clássicas", em que a turbulência financeira é o rebatimento de um problema na acumulação do capital produtivo, as crises "autenticamente" financeiras não se dão no ápice de uma fase de expansão, "não foram o aspecto propriamente financeiro de uma crise de superprodução clássica, [mas] têm como pano de fundo o contínuo declínio do crescimento dos países da OCDE",233.

Isso revela uma interação entre a atonia da produção gerada pela insaciabilidade da finança e essas crises. Os abalos financeiros colaboram para a desaceleração econômica, enquanto a diminuição do crescimento cria, por sua vez, um contexto propício à ocorrência de crises financeiras. Ainda que os oligopólios, por meio exatamente de sua posição privilegiada,

${ }^{230}$ CHESNAIS, “O capital portador de juros (...)”, pp. 63 e 64.

${ }^{231}$ CHESNAIS, "Mundialização financeira e vulnerabilidade sistêmica", p. 249.

${ }^{232}$ A esse respeito, viu-se que a exposição de Chesnais possui certas ambigüidades que suscitam críticas. Ele poderia precisar melhor a questão deixando mais claro, primeiramente, que as esferas financeira e produtiva não são separadas (embora ele afirme que "haveria uma interação de mão dupla entre a esfera financeira e a esfera de criação de valor (...) [e que] a atonia de crescimento constituiria um contexto propício à multiplicação dos abalos financeiros" - Ibidem, p. 253). Em segundo lugar, ele poderia insistir em que a "autonomia" da esfera financeira é relativa e mesmo ilusória (apenas colocar aspas nos termos não esclarece a questão). A crise, portanto, não pode ser "autenticamente" financeira, pois sempre se deve à interação (contraditória) entre as duas esferas. Isso não invalida, contudo, o esforço de distinguir crises que são cíclicas e decorrem diretamente da sobreacumulação do capital, para então ter efeito no plano financeiro, de crises mais recorrentes que se manifestam antes na própria esfera financeira e muitas vezes são diretamente provocadas pelos agentes financeiros.

${ }^{233}$ Ibidem, p. 252. 
tenham conseguido de certa forma se adaptar ao novo contexto por meio da reestruturação produtiva, não há indícios de que possam contornar esse cenário.

Chesnais defende ainda que os enfoques cíclicos deixaram de ser aplicáveis, pois à instabilidade financeira gerada pelos ciclos econômicos em si acrescenta-se essa fragilidade decorrente de desequilíbrios estruturais. Graves crises estouram a partir da especulação ou de uma “'instabilidade sistêmica' congênita" 234 e não pelo seguimento "normal” do ciclo econômico, estendendo, assim, suas conseqüências ao setor industrial e comercial. Ele descreve também as principais fontes de fragilidade sistêmica ${ }^{235}$, algumas das quais já foram mencionadas: o nível extremamente elevado de capital fictício devido à inflação dos preços dos ativos financeiros; a fragilização dos bancos, que não mais conseguem fornecer crédito e liquidez suficientes durante as $\operatorname{crises}^{236}$; o comportamento especulativo da finança que contamina outros setores (imobiliário, commodities); a desregulamentação dos mercados emergentes - que são mais frágeis e possuem dirigentes menos experientes - e sua inserção na mundialização de forma subalterna; e a insuficiência dos meios de injeção de liquidez em âmbito mundial e dos mecanismos de "socialização dos prejuízos".

Além disso, na própria dinâmica das crises intervêm fatores importantes. Em primeiro lugar, como foi aventado anteriormente, os riscos cada vez maiores assumidos pelos agentes, que alavancam suas posições, contribuem para a maximização dos desastres. Como o regime de acumulação financeirizado é carente de instâncias de supervisão e controle, os operadores apostam em raciocínios do tipo too big to fail (grande demais para quebrar) e na certeza de que sempre haverá emprestadores em última instância (FMI, BID, FED) para socorrê-los esse sim um mecanismo de intervenção recorrente e fundamental ${ }^{237}$. A existência de instituições que injetam liquidez no sistema ${ }^{238}$ leva ao chamado "risco moral", que, por sua vez, estimula operações cada vez mais temerárias. Ademais, elas impedem que a correção de preço dos ativos seja levada a termo, mantendo a ficção sempre em um patamar

\footnotetext{
${ }^{234}$ CHESNAIS, “O capital portador de juros (...)”, p. 63.

${ }^{235}$ Para mais detalhes consultar CHESNAIS, "Mundialização financeira e vulnerabilidade sistêmica".

${ }^{236}$ As soluções nacionais em geral se tornam insuficientes para fazer frente a abalos de ordem mundial.

${ }^{237} \mathrm{Ou}$ ainda os governos agem no sentido de "transferir" a bolha de um setor a outro para manter o crescimento, como ocorreu após o estouro da bolha das empresas de internet nos EUA, quando ela foi então alimentada no setor imobiliário - Cf. CHESNAIS, "La prééminence de la finance (...)”, pp. 119-120.

${ }^{238}$ E com o dólar sem lastro essa capacidade é extremamente elástica, sobretudo para os EUA. Com a crise de 2008, em 1 ano o governo dobrou a base monetária do país, colocando em circulação por volta de 1 trilhão de dólares a mais - Cf. NAKATANI e HERRERA, Crise financeira... ou de superprodução?.
} 
razoavelmente elevado ${ }^{239}$. Do lado do governo, essas injeções levam-no a endividar-se. De modo que, se não há uma recuperação econômica suficiente para que os pagamentos e impostos cubram os rombos, a dívida pública aumenta, significando mais uma vitória dos credores.

Em segundo lugar, há o comportamento mimético dos operadores financeiros, que têm necessidade de referências coletivas. Em um cenário de grande instabilidade, pequenas movimentações nos mercados financeiros podem desencadear reações de grandes proporções. Isso, por si só, já é um mecanismo de desestabilização. Porém, há também as crises orquestradas pelos próprios grandes investidores devido ao poder que lhes conferem as enormes somas sob seu controle. Elas são normalmente desencadeadas em mercados emergentes e se aproveitam do "efeito manada" que habitualmente acontece: "A capacidade de os operadores atingirem seus fins, em razão do volume de ativos que podem mobilizar, tanto diretamente quanto de forma 'alavancada' permite-lhes desencadear crises praticamente quando o desejarem"240. E como essas crises usualmente começam no mercado cambial, a resposta normalmente é a elevação dos juros por parte do banco central, o que melhora as oportunidades de valorização para o capital monetário nesse setor. Esse tipo de crise, portanto, acaba tendo por efeito, senão por função, o fortalecimento do regime financeirizado.

Nesse sentido, embora já em Marx a crise possua um estatuto fundamental por ser o momento de negatividade da acumulação do capital engendrado pelo próprio processo capitalista, ela parece ganhar relevância suplementar na teoria de Chesnais. Em primeiro lugar, porque as crises passam a ocorrer mais frequentemente devido à mudança no regime de acumulação, imprimindo uma dinâmica diferenciada no capitalismo ao mesmo tempo que abala sua estabilidade (pelo menos em comparação com o período fordista). Em segundo lugar, porque, como se viu, sua dimensão financeira muitas vezes não é a conseqüência direta da crise de acumulação do capital produtivo, mas se relaciona ao fator de desencadeamento. Elas assumem, assim, características diferenciadas e passam a ter um papel mais importante na centralização do capital e na reprodução da dominância financeira, sobretudo por meio de sua produção consciente pelos atores financeiros mais poderosos.

\footnotetext{
${ }^{239} \mathrm{Na}$ análise de Marx em $O$ Capital, o Estado não figura diretamente como um agente na economia, sobretudo no papel de emprestador em última instância. Desse modo, as crises tinham uma função corretiva muito maior do que hoje e provavelmente impediam que a proliferação de capital fictício chegasse a níveis tão elevados.

${ }^{240}$ CHESNAIS, "Mundialização financeira e vulnerabilidade sistêmica", p. 268.
} 
Por outro lado, a dimensão "desfetichizadora” das crises, também presente em Marx, é igualmente potencializada. Elas têm a capacidade de abrir brechas na opacidade mais densa da realidade constituída pelo predomínio do capital portador de juros e do capital fictício:

É próprio das crises financeiras (cuja uma das formas é o crash bursátil) revelar, à luz do dia, o caráter fictício dos títulos. Assim que certo patamar desse processo de desnudamento da 'verdadeira natureza' dos títulos é ultrapassado, o mecanismo ganha dinâmica própria e nada mais pode impedir um colapso completo de seu 'valor'. ${ }^{241}$

Nesse momento, fica claro que os títulos financeiros não representam capital efetivo nenhum, que os rendimentos prometidos só podem ser pagos a partir de uma produção de mercadorias que ainda não foi realizada e talvez não o possa ser. Fica igualmente patente que os títulos não possuem valor (por isso as aspas usadas por Chesnais), mas somente um preço, calculado através do raciocínio às avessas posto pelo princípio da capitalização e inflado de forma virtualmente ilimitada pela especulação ${ }^{242}$.

O segredo da "verdadeira natureza" do capital fictício aflora com o desvelamento da ideologia que o reveste: de um lado, ele é capital para seu possuidor individual, na medida em que o funcionamento regular dos mercados e a liquidez constitutiva destes permitem de fato sua conversão em dinheiro, ou seja, em riqueza efetiva. De outro lado, ele não é capital do ponto de vista social, uma vez que não há riqueza suficiente para materializá-lo integralmente. A contradição reside precisamente em que o capital fictício é "real" à condição que todos (ou muitos) não tentem convertê-lo em dinheiro ao mesmo tempo.

Durante a crise, para que o sistema não entre em colapso é imprescindível, pois, manter a qualquer custo a ficção em operação. Donde a importância fundamental dos emprestadores de última instância, instituições do qual esse capitalismo "desregulado"243 não pode abrir mão. É preciso:

Fazer de tudo para que os investidores permaneçam no mercado, que não se tornem todos vendedores de seus títulos, que permaneça uma massa suficiente de

${ }^{241}$ CHESNAIS, "La prééminence de la finance (...)", p. 117.

242 "As operações especulativas mais arriscadas podem conduzir, teoricamente, a perdas infinitas (...) Os montantes em jogo nessas transações, induzindo a criação de capital fictício, atualmente, ultrapassam de longe aquele montante destinado à reprodução do capital diretamente produtivo" - NAKATANI e HERRERA, Crise financeira... ou de superprodução?, p. 4.

${ }^{243}$ Como mencionado, o termo "desregulamentação" pode ser enganoso. Por trás da dissolução das barreiras ao capital está todo um reordenamento institucional, inclusive do Estado, com vista a assegurar o bom desenvolvimento da acumulação. A figura do emprestador de última instância é um dos dispositivos fundamentais. 
investidores dispostos a comprá-los. É aqui que intervém esse elemento tão fortemente diferenciado de país a país, a capacidade de 'curar o mal com o mal', isto é, de injetar liquidez que ajudará a evitar a destruição do capital fictício e que pode se transformar em capital fictício adicional. ${ }^{244}$

Os socorros financeiros restabelecem a dinâmica dos mercados financeiros através, portanto, da manutenção da ficção em certos patamares e, normalmente, do endividamento dos Estados. A finança ganha, então, duplamente: tem suas condições de reprodução e dominação mantidas e ainda encontra novas possibilidades de ganhos com títulos de dívida pública. Contudo, através dessa "política de fuga para frente", ${ }^{245}$ são mantidas, e reforçadas, as condições para novas crises (ainda mais profundas) no futuro.

Assim, parece que o caráter contraditório das crises se acirra devido às intervenções de peso dos Estados e das organizações internacionais. Por um lado, a crise desvela algumas mistificações do capitalismo financeiro, sobretudo no que se refere ao capital fictício e ao circuito D-D'. Além disso, ficam claros a dimensão política da economia e o caráter burguês do Estado, que precisa intervir de modo contundente para manter o sistema econômico funcionando. Surgem, assim, maiores possibilidades para a constituição de uma mobilização social contestatória.

Por outro lado, a crise possui repercussões negativas importantes sobre a classe trabalhadora, tolhendo sua iniciativa. Permite recompor as taxas de lucro rebaixando salários e estendendo jornadas de trabalho. A base objetiva disso é o aumento do contingente de desempregados e pobres que ela provoca em todo o mundo (exército de reserva), bem como o fortalecimento dos grupos oligopolizados devido à centralização de capital provocada. Por fim, ela acaba, apesar das perdas momentâneas de muitos, reafirmando as condições de poder da finança ao preço de acirrar as contradições do capitalismo.

\footnotetext{
${ }^{244}$ CHESNAIS, "La prééminence de la finance (...)", p. 118.

${ }^{245}$ Ibidem, p. 120. Essa expressão de Chesnais certamente se baseia em uma formulação mais ampla de Marx, por ele mesmo citada, sobre a dinâmica contraditória de auto-superação do capital: "A produção capitalista procura constantemente superar essas barreiras que lhe são imanentes, mas só as supera por meios que lhe antepõem novamente essas barreiras e em escala mais poderosa" - MARX, O Capital, Livro III (tomo IV), cap. 15 , p. 189.
} 


\section{CAPÍTULO 3 - O REGIME FINANCEIRIZADO}

De modo geral, Chesnais mostra em seus trabalhos como o triunfo do capital financeiro a partir dos anos 1980 se manifesta num arcabouço institucional, regulatório e político específico. Também elabora qual o impacto e o significado desse domínio do capital financeiro no funcionamento das sociedades capitalistas: "a 'mundialização' financeira possui, de modo evidente, a função de garantir a apropriação, em condições tão regulares e seguras quanto possível, das rendas financeiras - juros e dividendos - numa escala mundial",246.

Portanto, quando Chesnais afirma a existência de um predomínio da lógica do capital financeiro no período atual do capitalismo, desenvolve e atualiza a teoria de Marx anunciando uma especificidade do presente histórico. Percebe que um novo arranjo institucional tem sustentado modos de acumulação do capital diferentes daqueles do período fordista portanto, um novo regime de acumulação. Nesse sentido, é útil mobilizar certas noções da escola da regulação a fim de descrever esquematicamente o regime de acumulação com dominância financeira. A partir disso é possível marcar bem as diferenças essenciais entre este e o fordismo, assim como introduzir a crítica de Chesnais a Aglietta.

Ressalte-se, primeiramente, o predomínio da lógica financeira, de caráter rentista e especulativo. Nesse sentido, a tendência imanente do capital a operar no prazo mais curto possível pode se efetivar com princípios de gestão empresarial que privilegiam os acionistas portanto, a valorização das ações mais do que o investimento produtivo e o aumento da produtividade. A governança corporativa e a organização "flexível” da produção desembocam em um tipo de produção com relativamente menos recurso à força de trabalho e com postos de trabalho precarizados (terceirizações). Por conseguinte, são recriadas formas de exploração da mais-valia absoluta ${ }^{247}$ como forma de aumento dos lucros. O sistema passa a se basear em uma norma de consumo condizente com a concentração de renda e a exclusão social, em um contexto no qual as transações financeiras deixam de ser um propulsor da produção de mercadorias e passam até a inibir certos investimentos. Trata-se, pois, de um regime que produz grandes lucros, mas com baixa acumulação do capital.

${ }^{246}$ CHESNAIS, “A 'nova economia' (...)”, p. 53.

247 Esse processo está em estreita concordância com as considerações de Harvey sobre a "acumulação por espoliação". Essa questão também está presente em SALAMA, "A financeirização excludente: as lições das economias latino-americanas". 
No que se refere à "regulação",248 em vigor, pode-se defini-la como "rentista de mercado". As políticas keynesianas saem de cena com a implementação das normas neoliberais, transferindo prioritariamente ao mercado a regulação do sistema. Sua lógica baseia-se na rentabilidade dos ativos, donde seu caráter "rentista". Nessa conformação neoliberal do Estado, os antigos compromissos sociais são colocados em xeque e enfatiza-se a moeda como mercadoria privada, ou seja, um ativo passível de especulação como qualquer outro $^{249}$. À medida que o processo de transnacionalização das empresas avança, os Estados deixam de ser os centros exclusivos da regulação, já que muitos aspectos desta passam por normas e atores que não se limitam a um só Estado.

Quanto ao trabalho, predominam a flexibilização e precarização das relações trabalhistas (aumento dos trabalhos temporários e em tempo parcial; crescimento do número de autônomos; terceirização). A recriação de formas da mais-valia absoluta mencionada acima é possibilitada pela perda de direitos sociais e pela redução permanente no nível do emprego. A organização toyotista desarticula os coletivos de trabalho e dificulta as lutas por melhores condições para os trabalhadores. A desestabilização da vida daqueles que dependem da venda de sua força de trabalho, aliada ao aumento da concentração da renda, muitas vezes acaba levando a revoltas sociais.

No que se refere ao capital, ocorre um processo de subordinação da sua forma produtiva às imposições da esfera financeira, o que não significa que a produção efetiva de bens deixe de ser importante, mas que ela é dominada pela lógica rentista das finanças. As grandes empresas continuam se desenvolvendo, mas articulando-se em grupos (preferencialmente sob a forma jurídica de holdings) e se transnacionalizando. Nesse sentido, o Estado e sua organização também se "financeirizam", no sentido de que sua intervenção é comandada pelos interesses da esfera financeira e que ele também recorre a mecanismos da "era financeira", como a securitização de suas dívidas, swaps cambiais, etc.

O sistema monetário nascido em Bretton Woods entra em crise e é unilateralmente extinto, no início dos anos 1970, por Nixon, que substitui o padrão dólar-ouro pelo autoreferenciado dólar-dólar. A hegemonia estadunidense é reforçada pelo seu poder de

\footnotetext{
${ }^{248}$ Entre aspas, pois Chesnais coloca em dúvida a existência de um modo de regulação efetivo do atual regime de acumulação.

${ }^{249}$ Mas, deve-se ressaltar, com conseqüências especialmente importantes.
} 
senhoriagem ${ }^{250}$, advindo do novo padrão monetário. As finanças tornam-se desintermediadas (o sistema bancário perde centralidade para novos atores e instituições); regidas pelo mercado (os Estados revogam uma série de controles sobre os fluxos de capital); mundializadas (interligação dos sistemas financeiros de inúmeros países e ausência de "fronteiras" para o investimento); e especulativas (não servem mais prioritariamente ao fomento do setor industrial, mas ao ganho sobre oscilações de preço na compra e venda de ativos).

Os Estados são responsáveis por transferências importantes de renda para a esfera financeira devido ao financiamento da dívida pública. Eles recorrem frequentemente a taxas de juros elevadas (políticas monetárias restritivas, que pesam sobre o nível dos salários), a políticas desinflacionistas e às privatizações. Adotam ainda regimes de câmbio flexível (em conformidade com a visão da moeda como ativo financeiro, cujo "preço" deve flutuar segundo as leis de mercado). As transações com moeda, portanto, deixam de se destinar prioritariamente a operacionalizar exportações e importações e passam a ser objeto de especulação nos mercados financeiros, contribuindo para desestabilizar o ambiente monetário.

Por fim, aprofunda-se a mundialização, com a dinâmica global se impondo com mais força às economias nacionais. Estas, com a eliminação do controle sobre capitais, tornam-se mais abertas, de modo que há redução da autonomia dos Estados na defesa dos interesses nacionais e em proceder a compensações de ordem social. Legislações e organismos internacionais ganham poder de interferência e pressão sobre os países, sobretudo do Terceiro Mundo. Com o dinamismo e fluidez dos fluxos financeiros, acentua-se igualmente a hierarquia entre os países.

Embora Chesnais trabalhe com o conceito de "regime de acumulação", é bastante cético quanto à viabilidade de se aplicar o conceito de "modo de regulação" ao atual período do capitalismo. Em franca oposição a Michel Aglietta, que vislumbra a consolidação de um determinado padrão de crescimento do capitalismo, ele afirma que "o termo 'regime de

\footnotetext{
250 "Senhoriagem" é um mecanismo do qual o governo dispõe, derivado da sua prerrogativa exclusiva de criar moeda (portanto de valorizá-la ou desvalorizá-la), usado geralmente para ampliar suas receitas (em detrimento dos detentores da sua moeda). No plano internacional, essa vantagem é privilégio dos EUA, cuja moeda nacional é também o dinheiro mundial.
} 


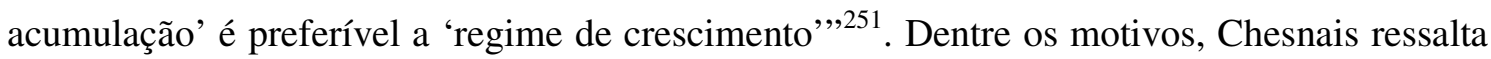
o fato de que a presente configuração do capitalismo é antes um obstáculo ao crescimento econômico, sendo a "exceção" norte-americana - base das considerações de Aglietta atribuída à posição muito singular dos EUA no sistema mundial.

Para Chesnais - ainda que sua posição sofra uma inflexão - os EUA seguem sendo a potência dominante que dirige a economia mundial ${ }^{252}$, por diversos fatores, entre eles: seu poder militar e ideológico, seu papel de condução e difusão da mundialização do capital, a magnitude e sofisticação de seus mercados financeiros (que superam a do seu setor industrial), o poder de senhoriagem que o dólar lhe confere por ser a moeda mundial e o fim da União Soviética como contraponto a seu poderio. Em seu primeiro livro, Chesnais afirma que no atual regime de acumulação "aumentou o peso dos Estados Unidos, não apenas devido ao desmoronamento da União Soviética e à sua posição militar inigualável, mas também à sua posição no plano do capital financeiro (...) [de modo que] os Estados Unidos gozam de uma situação sem precedentes na história" ${ }^{, 253}$. Essa continua sendo fundamentalmente a posição defendida em seu texto de 2001, no qual foca a análise nos EUA. Além de reafirmar a posição destes, o autor ressalta que as condições de seu sucesso econômico não são generalizáveis aos demais países:

\footnotetext{
À luz da experiência dos Estados Unidos ao longo dos anos 1990, o crescimento em regime de acumulação com dominância financeira supõe a capacidade de satisfazer várias condições. Nada permite afirmar que estas estejam ao alcance de países que não ocupam o lugar dos Estados Unidos no sistema mundial, nem experimentaram sua trajetória histórica enquanto formação social. ${ }^{254}$
}

${ }^{251}$ CHESNAIS, “A 'nova economia' (...)”, p. 47.

${ }^{252}$ A posição ocupada pelos EUA atualmente é questão bastante controversa, como se verifica a partir dos pontos de vistas defendidos por Chesnais e por Arrighi, por exemplo. Eles estão em desacordo sobre a implicação "política" da financeirização. Para Arrighi, com seu enfoque cíclico de longa duração, a fase de expansão financeira teria um sentido geopolítico oposto ao de Chesnais: é o período de transição de uma hegemonia para outra, anunciado precisamente pelo fato de os capitais industrial e comercial migrarem para as finanças devido ao cenário econômico. O país central em declínio recorre às operações financeiras para tentar sustentar ou prolongar sua dominância. Contudo, esse recurso é limitado: quando outro país consegue tomar a dianteira no setor produtivo, vai aos poucos substituindo aquele na posição hegemônica, dando origem a uma nova fase de expansão material. Assim, em conformidade com suas convicções teóricas e operando através de um raciocínio histórico "indutivo", Arrighi avança a hipótese de que o cenário atual provavelmente assinalaria o declínio da hegemonia mundial estadunidense.

${ }^{253}$ CHESNAIS, A mundialização do capital, p. 19.

${ }^{254}$ CHESNAIS, “A 'nova economia' (...), p. 54. 
Uma relativização da situação estadunidense ${ }^{255}$ só aparece em 2004 , e baseia-se no florescimento econômico da China no cenário mundial:

O papel desempenhado pelos Estados Unidos na expansão do processo de liberalização e de privatização no mundo e o lugar que ocupam na configuração da mundialização capitalista tiveram como consequiência a criação de um efeito óptico deformante, encorajando os pesquisadores a enxergar a mundialização como, antes de tudo, a projeção sistêmica da hegemonia norte-americana. Ainda é esse, amplamente, o caso para A finança mundializada. Nosso livro permanece centrado na posição e no papel dos Estados Unidos (...) A irrupção da China como potência econômica é fator de primeira ordem na configuração das relações sistêmicas mundiais e deve encaminhar os pesquisadores a se desvincularem dessa ótica. ${ }^{256}$

De todo modo, a questão parece ser que a instabilidade do regime com dominância financeira, sua fragilidade sistêmica, não permite defini-lo como um modo de desenvolvimento acabado. Continuando seu diálogo com Aglietta, Chesnais se pergunta se "o 'regime patrimonial' ou 'financeirizado' satisfaz os critérios colocados pela teoria da regulação, especialmente no que concerne à solidez necessária dos compromissos sociais" 257 . A resposta seria que, embora já dure algumas décadas, o atual regime de acumulação não adquiriu no mundo uma estabilidade suficiente para assegurar sua viabilidade a longo prazo, e mesmo nos EUA o crescimento só foi possível por causa de bolhas financeiras.

Ademais, o que Aglietta veria como uma "dívida social" 258 - a poupança centralizada pelos fundos de pensão - que os investidores institucionais têm a responsabilidade de gerir, Chesnais entende ser a transformação de grandes somas de dinheiro, originadas de salários, em capital a ser valorizado financeiramente, ou seja, uma mudança radical da natureza dessa riqueza $^{259}$.

\footnotetext{
${ }^{255}$ Nakatani e Marques concluem um de seus textos também com uma ressalva ao poder estadunidense devido às bases nas quais ele assenta: "é necessário dizer que essa força dos Estados Unidos é apenas relativa, pois do ponto de vista econômico, sua economia está fortemente estruturada na acumulação de capital fictício, na maximização do valor das ações e no crescimento exorbitante do consumo, o que a fragiliza e reforça a necessidade de sua ação militar no mundo. A nova manifestação da crise na esfera financeira, e desta vez no interior do sistema financeiro norte-americano, desvenda essa fragilidade. Entretanto, isso não significa o fim do capitalismo e nem do imperialismo americano. Mas, pode ser um momento ímpar para que as forças progressistas de todo o mundo comecem a questionar decisivamente a viabilidade desta forma de organização, de produção, de distribuição e do padrão de consumo a que chegou o capitalismo contemporâneo" NAKATANI e MARQUES, “A finança capitalista: a contribuição de François Chesnais para a compreensão do capitalismo contemporâneo" p. 18.

${ }^{256}$ CHESNAIS, A finança mundializada, pp. 20 e 21.

${ }^{257}$ CHESNAIS, "La théorie du regime d'accumulation financiarisé (...)", p. 12.

258 Termo de Aglietta citado por Chesnais.

${ }^{259}$ Cf. Ibidem, item II-1.
} 
Já foi exposto o que essa mutação implica: processos especulativos e fictícios, por um lado, e punções da mais-valia, por outro, ambos pressionando por maior exploração do trabalho. Como um "compromisso social" poderia surgir de tal situação é difícil de conceber $^{260}$. Mesmo porque o poder que os assalariados aposentados possuem como acionistas, na prática, é apenas formal. Retomando Lordon, Chesnais afirma que os fundos de pensão são, na verdade, formas de quebrar a unidade política dos trabalhadores ${ }^{261}$. O fator trabalho tornou-se uma variável fundamental de ajustamento do sistema econômico, de modo que redução de salários, demissões e flexibilização dos postos de trabalho sempre se sobreporão a qualquer "poder acionário" que os assalariados eventualmente possuam.

Nesse sentido, como foi visto, o agente da "regulação" deixa de ser prioritariamente o Estado ou as negociações coletivas e passa a ser fundamentalmente os mercados financeiros:

A configuração do regime financeirizado supõe que os mercados financeiros substituam as políticas econômicas e as convenções coletivas salariais fordistas e ocupem seu lugar na determinação do nível da demanda e, portanto, da atividade econômica. Serão eles capazes disso?. ${ }^{262}$

Enfim, a argumentação geral de Aglietta para defender a existência de um regime de crescimento gira em torno de três eixos que Chesnais comenta criticamente e que serão apenas mencionados ${ }^{263}$. Primeiramente, há a questão da inovação e da produtividade. Chesnais relativiza a performance dos EUA recorrendo a autores que mostram não ter havido mudança significativa da produtividade em muitos setores da economia estadunidense. Em segundo lugar, Aglietta refere-se aos efeitos benéficos da governança corporativa, o que é criticado não só por Chesnais, mas também por outros autores, como André Orléan. Eles mostram a precarização e diminuição do emprego (entre outros efeitos negativos) que acirram a oposição capital/trabalho e que decorrem dos princípios da governança corporativa. Por fim, há as funções atribuídas pelo regime financeirizado aos mercados financeiros, que estes seriam capazes de executar de forma satisfatória, tais como orientar o investimento, repartir a renda e definir o nível de consumo das famílias. Contudo, a lógica rentista e o uso do trabalho como variável-chave de ajustamento revelam a impossibilidade de conjugar o funcionamento

\footnotetext{
${ }^{260}$ Isso sem contar os demais agentes da finança, como os fundos de investimento, cujo compromisso com os rendimentos do trabalho é ainda menor, bem como o fato de que os sistemas de aposentadoria de prestações definidas sempre abrangeram uma pequena parte dos assalariados (predominando os sistemas de cotização definida).

${ }^{261}$ Cf. CHESNAIS, "La théorie du regime d'accumulation financiarisé (...)", pp. 15 e 16.

262 Ibidem, p. 22.

${ }^{263}$ Para mais detalhes, Cf. Ibidem, item II-2.
} 
dos mercados financeiros e essas "funções". Portanto, Chesnais afirma se posicionar no pólo oposto ao de Aglietta quanto à existência de um "círculo virtuoso" no atual regime:

\footnotetext{
Para mim, as coerências sistêmicas, situadas já de início no contexto da mundialização do capital, conduzem à emergência de um tipo de 'regime macroeconômico' da economia mundial 'globalizada' dominado pela presença de encadeamentos 'viciosos' orientados no sentido de um crescimento lento ou muito lento e também cada vez mais desigual. ${ }^{264}$
}

Depreende-se da periodização feita por Chesnais que o retorno do poderio do capital financeiro ocorre efetivamente a partir da segunda etapa da mundialização financeira, nos anos 1980, quando dos processos de desregulamentação monetária e financeira, da desintermediação bancária e da descompartimentalização dos mercados financeiros. Diferentemente do período que precedeu a Primeira Guerra Mundial, hoje há duas particularidades muito importantes que singularizam o atual regime de acumulação. Primeiramente, com o fim do lastro-ouro do dólar, o dinheiro mundial é uma moeda nacional inconversível, desvinculada, pois, de qualquer mercadoria em especial e garantida em grande medida pelo aparato econômico-militar dos EUA. A capacidade de multiplicação do dinheiro na sua determinação de meio de pagamento é, consequentemente, exponencialmente ampliada. Esse fator acaba permitindo uma ampliação desmesurada do capital fictício em geral, o que leva à segunda peculiaridade do atual regime: os dados e outros elementos fornecidos ao longo desta dissertação sugerem que o principal "artigo" transacionado atualmente no mundo é o próprio capital (capital portador de juros), o que revela a irracionalidade desse, por falta de um termo mais adequado, "meta-capitalismo".

Na questão do imperialismo do início do século XX, Hilferding e Lênin trabalhavam, ao se referirem à monopolização, principalmente com dados distribuídos por países, e não em âmbito mundial. Do mesmo modo, a exportação de capital se dava em bases nacionais: empresas estreitamente ligadas a um Estado nacional mobilizavam seu capital para investimentos em outros países. Hoje, o nível de interncionalização das empresas é muito maior (transnacionalização). Os grandes conglomerados estão presentes em um número de

${ }^{264}$ CHESNAIS, “La théorie du regime d'accumulation financiarisé (...)”, p. 17. 
países muito maior e em muitos casos a maior parte de suas operações e da sua lucratividade não se situam no país de origem ${ }^{265}$.

Além disso, antes o domínio da finança se dava por intermédio de sua inserção na indústria, controlando-a, pois o capital industrial era mais importante, e o crédito ainda era destinado à produção de mercadorias. Hoje, o poder da finança se faz sentir efetivamente pela predominância do capital portador de juros, sobretudo em sua forma fictícia ${ }^{266}$, já que também há um movimento de as indústrias se "financeirizarem"267.

Sendo a forma mais fetichista do capital, o capital portador de juros significa, assim, provavelmente o grau máximo de "libertação" do capital de suas próprias determinações. O período atual é, portanto, a efetivação histórica dessa etapa lógica exposta por Marx no livro III de $O$ Capital. Por conseguinte, esse retorno do capital financeiro se assenta:

Em bases muito mais profundas do que no passado (...) [e] foi acompanhado da construção de uma nova relação entre o capital produtivo, o capital comercial e o capital financeiro [com predomínio deste - I.L.] e por uma nova correlação de forças entre o capital e o trabalho, desfavorável a este último. ${ }^{268}$

Esse novo cenário constituiu-se a partir de sucessivas derrotas da classe trabalhadora: elevada taxa de desemprego (que mantém um numeroso exército de reserva), redução de salários e precarização das relações de trabalho, deslocalizações das fábricas para países cujo custo da força de trabalho é muito mais baixo, etc. A combinação de uma elevada exploração do trabalho com baixas taxas de crescimento - pois o aumento de produtividade não se destinou necessariamente à ampliação da produção - revela, assim, um capitalismo sob um

\footnotetext{
265 É o que sugere Harvey, por exemplo, ao apontar a "emergência de corporações capitalistas transnacionais que, ainda que pudessem ter sua base em uma ou outra nação-Estado, se disseminaram pelo mapa do mundo de maneiras impensáveis em fases anteriores do imperialismo (os trustes e cartéis que Lênin e Hilferding descreveram estavam todos ligados muito estreitamente a nações-Estado particulares)" - HARVEY, O novo imperialismo, p. 62.

${ }^{266}$ A mudança na composição dos investimentos externos diretos é bastante expressiva desse movimento: a participação dos investimentos em carteira se eleva enormemente em relação aos investimentos diretos "propriamente ditos" - Cf. CHESNAIS, A mundialização do capital, pp. 58 e 59.

${ }^{267} \mathrm{O}$ desenvolvimento do raciocínio parece ser oposto ao de Hilferding em determinado sentido: não só um capital monetário (dos bancos) que se torna industrial, mas um capital industrial que se torna progressivamente "financeiro", ao se envolver com essas atividades e se subordinar à lógica e às exigências da esfera financeira. Chesnais propõe, pois, duas "atualizações" (Cf. CHESNAIS, "États rentiers dominants et contraction tendencielle: Formes contemporaines de l'impérialisme et de la crise”, pp. 105-107) do trabalho de Hilferding sobre o capital financeiro, ou seja, duas formas contemporâneas de interconexão entre a finança concentrada e a grande indústria: a financeirização dos grupos ("grupos financeiros com dominância industrial") e a entrada de fundos de investimento e de pensão, companhias de seguro, etc. no capital dos grandes grupos (internalização da exterioridade da finança).

${ }^{268}$ NAKATANI e MARQUES, “A finança capitalista: a contribuição (...)”, p. 16.
} 
regime contraditório de baixa acumulação e elevado nível de lucro ${ }^{269}$, como também aponta Chesnais de modo contundente:

As características do investimento produtivo, do ponto de vista do ritmo, do montante e da orientação setorial (...) levam a formular a hipótese de que, pela primeira vez na história do capitalismo, no centro do sistema, a acumulação do capital não mais se coloca claramente sob o signo da reprodução ampliada. ${ }^{270}$

Para que esse elevado nível de lucro (cuja norma está internacionalizada e tem como referência a China e outros países onde se pratica elevada exploração do trabalho) se conserve e os mercados financeiros continuem sendo alimentados pela mais-valia obtida na produção, é essencial a manutenção de baixos salários e altas taxas de desemprego. Desse modo, devido à própria lógica do sistema, não parece haver perspectiva de retomada do crescimento econômico de forma expressiva e sustentada ${ }^{271}$. Com as possibilidades fetichistas abertas pelo retorno da finança, acaba sendo melhor não produzir do que o fazer com taxa de lucro inferior às normas mundiais, ou então é necessário "completar" a lucratividade nos mercados financeiros.

Esse ponto traz de volta a questão dos grandes grupos industriais mundializados. Como foi visto, nessas empresas - pressionadas pela mundialização da economia e pelos investidores institucionais que se tornam seus acionistas - as dimensões produtiva e financeira estão inextricavelmente associadas na condução das operações cotidianas. É por isso que Claude Serfati refere-se a elas como "grupos predominantemente industriais"272, e Chesnais, mais explicitamente, como "grupos financeiros de predominância industrial"273. Contudo, apesar de não haver mais essa separação tão clara entre suas atividades produtivas e financeiras $^{274}$, a diferença essencial entre um capital que se valoriza produtivamente gerando mercadorias e mais-valia, de um lado, e um capital que se reproduz através de punções da mais-valia e de processos fictícios nos mercados financeiros, de outro, é impossível de ser

${ }^{269}$ Cf. NAKATANI e MARQUES, “A finança capitalista: a contribuição (...)”, p. 17.

${ }^{270}$ CHESNAIS, "Mundialização financeira e vulnerabilidade sistêmica", p. 262.

271 A acumulação produtiva, contraditoriamente, chega a ser "indesejável" para o capital financeiro, como salienta Teixeira: "Nesse sentido, o sucesso da acumulação produtiva pode ser mesmo prejudicial ao capital, visto que o pleno emprego reduz o exército industrial de reserva e acaba pressionando por aumentos de salários e pela repartição dos ganhos de produtividade" - TEIXEIRA, Dependência, desenvolvimento e dominância financeira, p. 86, nota 51.

${ }^{272}$ SERFATI, "O papel ativo dos grupos predominantemente industriais na financeirização da economia".

${ }^{273}$ CHESNAIS, A mundialização do capital, p. 275 (itálico nosso).

${ }^{274}$ E talvez também entre os "suportes" do capital monetário e industrial, conforme as indagações feitas no final do Capítulo 1 sobre a atual configuração da burguesia. Afinal, ainda é possível falar em uma burguesia "industrial" propriamente dita? 
suprimida. A relação mais estreita entre as duas formas do capital não significa a dissolução das diferenças entre seus respectivos modos de circulação e valorização.

Segundo Chesnais, essa constatação é fundamental por dois motivos: por permitir analisar o nível, o ritmo e a orientação da acumulação e por esclarecer a origem das tensões insuperáveis no cerne desses grupos, que chegam a criar cisões nas diretorias entre defensores da "produção" e "financistas".

Nesse sentido, o objetivo dos grupos, talvez diferentemente do período fordista, é menos o crescimento em si da empresa - que acaba ao menos ampliando a produção de bens e empregando mais força de trabalho -, mas a obtenção de lucros via ganhos relativos de produtividade e operações financeiras. Fecham-se mais facilmente unidades produtivas que não atingem as elevadas metas de rentabilidade. Segundo Dominique Plihon, "nesse novo regime, o tamanho da empresa e os postos de trabalho se tornam variáveis de ajustamento",275, de modo que, para os próprios agentes, a produção em si perde importância para a lógica (abstrata) dominante do capital, tornando-se mais do que nunca um "mal necessário"276 na valorização do valor. Nessa relação complexa entre produção e mercados financeiros ${ }^{277}$ - mas também entre Estados nacionais e finança internacionalizada -, o movimento do capital é colocado sob o comando de dois mecanismos:

De um lado, se está na presença de mercados financeiros capazes tanto de condenar ao desaparecimento setores industriais inteiros se isso puder aumentar o valor acionário de alguns grupos, ou de destruir a economia de um país débil através da especulação, quanto de ceder a movimentos coletivos de pânico financeiro. Simultaneamente se está frente ao jogo devastador de uma concorrência desmesurada que vence as estratégias oligopolistas destinadas a contê-la, cujo um dos componentes é um movimento de internacionalização do capital produtivo com traços novos. ${ }^{278}$

\footnotetext{
${ }^{275}$ PLIHON, “Au nom des entreprises?”.

${ }^{276}$ MARX, O Capital, Livro II (tomo III), cap. 1, p. 44.

277 Sobre essa intrincada relação Plihon ainda acrescenta: "Se eles não contribuem realmente para o financiamento das empresas, qual é então a utilidade econômica dos mercados financeiros e, em particular, de seus principais atores que são os fundos de pensão? Essencialmente é a de facilitar as reestruturações do capitalismo moderno por operações de crescimento externo, de tomadas de controle (OPA) e de fusõesaquisições. Comprando e vendendo suas participações, os fundos de pensão [e outros investidores institucionais - I.L.] fazem circular o capital e aceleram a evolução rumo a uma nova configuração caracterizada pela tomada de controle do capital produtivo pelos investidores (fundos de pensão, fundos de investimento e seguros) e, simultaneamente, pela criação de uma classe de rentistas no prórpio seio do salariado" - PLIHON, "Au nom des entreprises".

${ }^{278}$ CHESNAIS, "La prééminence de la finance (...)”, p. 115.
} 
A classe trabalhadora em geral é a grande perdedora nesse processo, pois vê suas condições de vida se deteriorarem. Quanto aos estratos relativamente mais bem posicionados, como os assalariados formais, que muitas vezes são também cotistas de fundos privados de aposentadoria, a situação não é essencialmente diferente. A posição contraditória ocupada por eles e diagnosticada por Chesnais - da cisão de sua personalidade social - é retomada por Plihon em seu aspecto manifestamente negativo:

Esses assalariados-rentistas são, assim, duplamente perdedores: como assalariados, suportam as consequiências da 'flexibilidade' exigida pela busca desenfreada do lucro máximo imediato; como poupadores, eles assumem, na linha de frente, os riscos ligados à instabilidade dos mercados financeiros. ${ }^{279}$

Nesse sentido, fica mais claro que a mundialização do capital não é apenas um fenômeno econômico, no sentido de uma determinada forma de se produzir mercadorias, mas é igualmente um "modo de dominação social" ${ }^{280}$. Chesnais enfatiza que um de seus tentáculos é a indústria de "mídia", um ramo importantíssimo de reprodução do capital. Ela não só nivela a cultura, homogeneizando em âmbito mundial a demanda a ser atendida, como também produz um "condicionamento subjetivo" 281 das pessoas. A conclusão é de que se está "nos antípodas das esperanças de Polanyi"282 de uma reapropriação do econômico pelo social, já que o fetichismo da mercadoria é extremado e a primazia do econômico não parece ser questionada.

Marx afirma diversas vezes que o fundamento do capital em geral é a propriedade privada e que a "sacralização" desta - ou seja, sua promoção e garantia a qualquer custo - é um dos pilares da ordem burguesa. Contudo, a dominância do capital financeiro introduz uma forma específica de propriedade, que se baseia na valorização patrimonial (e na liquidez ${ }^{283}$. Se, por um lado, o capital industrial se baseia na propriedade privada e não pode prescindir da garantia desta, por outro, ele se constitui em produção de riqueza efetiva, de mercadorias das quais outras pessoas dependem, além de fornecer diretamente a renda aos trabalhadores. Cria-

\footnotetext{
${ }^{279}$ PLIHON, "Au nom des entreprises?"

${ }^{280}$ CHESNAIS, "Notes pour la discussion du 8 mars au groupe de travail au Centre de Sociologie européenne", p. 13.

${ }^{281}$ Cf. CHESNAIS, A mundialização do capital, p. 40 e 41.

282 Ibidem, p. 42.

${ }^{283}$ Cf. CHESNAIS, “O capital portador de juros (...)”, p. 65.
} 
se, assim, um poder também "efetivo" e materialmente fundamentado. Já em relação ao capital financeiro, parece que somente a propriedade privada é, em última instância, seu fundamento $^{284}$. A finança, sendo externa à produção e alimentando-se de punções da maisvalia, depende mais do que nunca de que os direitos de "pura" propriedade sejam sustentados por um aparato legal-militar e ampliados por medidas políticas.

Chesnais e Alain Bihr afirmam que "um dos mais importantes objetivos e resultados do processo de desregulamentação e de privatização das duas últimas décadas foi ampliar consideravelmente a esfera da propriedade privada" ${ }^{285}$. Donde se deduz que o regime financeirizado se constitui em um passo além no movimento de reforço e expansão da propriedade privada. Quanto mais áreas estiverem sob o império desta, mais oportunidades se abrem para o rentismo, como, por exemplo, as privatizações de setores antes controlados e administrados pelo Estado e até mesmo "bens naturais" - como no caso emblemático da água da chuva na Bolívia.

Há, ainda, um ponto que se tornou central no capitalismo contemporâneo: a propriedade intelectual. Para além de ser um mecanismo imperialista que proporciona afluxos de riqueza para os países produtores de tecnologia (geralmente os países centrais), ao mesmo tempo que interpõe obstáculos ao desenvolvimento dos emergentes, ela significa uma ampliação do fetichismo. A propriedade intelectual é a transformação do conhecimento humano coletivo em mercadoria por meio da apropriação privada de um conjunto indeterminável de saberes e contribuições - em parte financiado com dinheiro público - e da exploração rentista de seus resultados. Chesnais e Bihr são bastante contundentes a esse respeito:

De fato, cada vez que um grupo farmacêutico patenteia um medicamento, ele se apropria dos conhecimentos científicos produzidos socialmente e financiados publicamente. Pois o produto patenteado é sempre conseqüência simultaneamente de uma longa acumulação geral de saberes feita independentemente do grupo que patenteia; e do resultado de trabalhos precisos de pesquisadores que normalmente trabalham em laboratórios de um ou vários países. A patente organiza e defende

\footnotetext{
284 Evidentemente, o capital portador de juros e o crédito possuem no capitalismo papéis importantes de coordenação da economia e de ampliação das capacidades produtivas, o que fundamenta o poder do capital financeiro e da finança. Porém, essas funções possuem um caráter mais "abstrato" e ambíguo: o capital portador de juros introduz uma relação entre capitalistas e não entre capital e trabalho - sendo, portanto, "inútil" do ponto de vista do trabalho - e o crédito é uma força coordenadora sobretudo de alocação do capital. Além disso, o grau de punção a que chegou o capital fictício é muito elevado. Dessa forma, parece que somente a sacralização da propriedade privada é que sustenta o capital financeiro, tornando explícito o fundamento do capital em geral.

${ }^{285}$ CHESNAIS e BIHR, “À bas la propriété privée”.
} 
juridicamente esse processo de expropriação dos pesquisadores e dos países que os financiam. Ela permite, em seguida, que os grupos oligopolistas transformem o saber social assim privatizado em mecanismo de extração de fluxos de renda e em instrumento de dominação social e política. ${ }^{286}$

A atividade "financeira", que primitivamente era encarnada pela usura, sempre foi vista com certa desconfiança pelas pessoas. O estigma advém precisamente da percepção (no caso da usura, bastante direta) de uma exploração "injustificada" e de uma vida "sem trabalho", diferentemente do industrial que, como vimos, pode ideologicamente alegar sua "contribuição" no sentido de prover o mundo de suas "tão necessárias" mercadorias e de fornecer a remuneração para que se comprem as mesmas.

Atualmente, também se podem observar mostras de descontentamento contra o regime patrimonial: as lutas contra as patentes e outras formas de propriedade intelectual; os protestos em relação aos estragos feitos pela crise financeira mundial e ao socorro dos Estados; os movimentos campesinos (em oposição a um tipo de rentismo não-financeiro, mas que cada vez mais se entrelaça com ele), etc.

Contudo, apesar de pontos de resistência e enfrentamento, o capitalismo patrimonial não parece estar seriamente ameaçado por forças sociais. O "estigma" da finança não parece ter tanta adesão, justamente no período em que ela mais se afirma. A questão que imediatamente surge é a da justificação ideológica que pode dar suporte à finança. Como uma dominação "parasitária" desse tipo - fundada na propriedade privada em seu estado mais puro e inteiramente dependente dela, que se apropria indiretamente das riquezas produzidas, que submete bilhões de pessoas a condições mais duras de vida e da qual apenas uma minoria no planeta se beneficia - pode se manter?

Evidentemente, o poder material das instituições da finança, bem como a coerção violenta, existem e estão realmente a serviço da propriedade privada, mas provavelmente fatores mais ideológicos e de cooptação ajudam a explicar a submissão de tantos por tão poucos. Alguns pontos importantes podem ser então aventados para se compreender a especificidade da dominação da finança, mesmo que não seja possível levar a termo uma investigação tão complexa no âmbito deste trabalho.

\footnotetext{
${ }^{286}$ CHESNAIS e BIHR, “À bas la propriété privée”.
} 
Primeiramente, existem mecanismos que atrelam o destino dos trabalhadores aos circuitos financeiros, tais como os fundos de pensão, a oferta de crédito pessoal - que permite o acesso a uma miríade de bens em troca do pagamento de juros - e os mais diversos tipos de aplicações e produtos financeiros oferecidos por bancos e outras instituições a seus clientes de todos os níveis de renda. Em segundo lugar, há a opacidade inerente às atividades financeiras, devido a seu caráter abstrato e "distanciado", que dificulta o entendimento do seu real funcionamento e significado pelas pessoas em geral. Por fim, há tanto a penetração da propriedade privada nos indivíduos como um valor moral, através de um processo sociocultural de longa data capitaneado pela burguesia - justificando todo e qualquer uso do dinheiro por parte de seu possuidor -, quanto os raciocínios do tipo "os mercados financeiros financiam nossas empresas e o Estado".

Assim, as séries de dispositivos "econômico-materiais" e "socio-ideológicos" mobilizadas em âmbito mundial por governos, instituições e capitalistas a serviço da mundialização do capital e do poder da finança, criando fortes hierarquias entre países e acirrando as contradições de classes, parecem justificar a proposição de Chesnais de que:

Encontramos-nos manifestamente em presença de mecanismos e de políticas conscientes de reprodução de uma dominação social mundializada. Devido ao nível atingido pela polarização da riqueza, essa dominação em escala global é a de uma pequena, senão de uma pequeníssima, fração da humanidade concentrada ela mesma majoritariamente nos países capitalistas avançados. A dominação se assenta em bases nas quais o 'econômico' e o 'político' estão inextricavelmente entrelaçados. $^{287}$

${ }^{287}$ CHESNAIS, “Notes pour la discussion (...)”, p. 13. 


\section{PARTE II - DAVID HARVEY: ACUMULAÇÃO 'FLEXÍVEL', NEOLIBERALISMO E IMPERIALISMO}




\section{CAPÍTULO 4 - FINANCEIRIZAÇÃo E REGIME 'FLEXÍVEL' DE ACUMULAÇÃO}

David Harvey enceta, como salientado, um diálogo com a escola da regulação em seu livro de 1989, Condição pós-moderna. Do mesmo modo que Chesnais, reconhece a transição de um regime de acumulação para outro, que data dos anos 1970. Embora Harvey seja cauteloso - afirmando que ainda não se pode ter certeza da emergência efetiva de um novo regime de acumulação e de um novo modo de regulação, mesmo porque o fordismo não teria desaparecido por completo - defende que há fortes indícios para se assumir tal hipótese ${ }^{288}$.

Diferentemente de Chesnais, contudo, o regime nascente não é definido em termos de "dominância financeira", mas de "acumulação flexível". Apesar da ênfase no regime de acumulação, Harvey elaborou, nessa obra, uma periodização do capitalismo que, na realidade, não enfatiza tanto o padrão de acumulação do capital, mas as transformações no processo de produção de mercadorias.

Essas duas formas de caracterizar e periodizar o capitalismo estão presentes na obra de Marx, mas autores marxistas tenderam, em suas análises, a separá-las ou a enfatizar uma em detrimento da outra. A primeira dessas formas, mais abstrata, denominada padrão de acumulação, concentra-se nos elementos que definem o modo pelo qual se gera e extrai valor, ou seja, em como o capital é aplicado para se valorizar e qual o circuito que percorre ao circular. Por exemplo: fase de expansão financeira ou fase de expansão material (Arrighi), a centralidade da exploração de mais-valia ou da apropriação direta de valor (Harvey, em $O$ novo imperialismo), dominância da "valorização financeira" ou não (Chesnais).

A segunda, mais concreta/visível, designada como forma de produção, foca as características assumidas pela produção de mercadorias, ou seja, a evolução da organização produtiva - normalmente relacionada às estratégias de obtenção de mais-valia relativa. É, por exemplo, o que o próprio Marx faz em $O$ Capital $^{289}$, ao distinguir os momentos da cooperação, da manufatura e da grande indústria (e que Ruy Fausto estende até a "pós-grande indústria"290). A diferença entre as duas abordagens fica nítida na crítica que Eleutério faz a

\footnotetext{
${ }^{288}$ Cf. HARVEY, Condição pós-moderna, p. 119.

${ }^{289}$ Cf. MARX, O Capital, Livro I (tomos I e II), cap. 11, 12 e 13.

${ }^{290}$ Cf. FAUSTO Marx: lógica e política (tomo III).
} 
Chesnais a esse respeito ${ }^{291}$ : este conceberia "a transformação histórica recente do capitalismo como mudança de regime de acumulação [padrão de acumulação - I.L.] e não como mudança interna do próprio modo de produção [forma de produção - I.L.]" ${ }^{292}$.

Nesse sentido, a "flexibilidade" do atual regime de acumulação, tal como definida por Harvey, tem como um de seus principais eixos as práticas de organização e gestão dos processos industriais, de comercialização e de trabalho (forma de produção), desviando-se pelo menos inicialmente - da questão do padrão de acumulação ${ }^{293}$. Por isso, há certa incoerência por parte de Harvey ao falar em “acumulação flexível”. Embora o processo não se resuma a transformações no interior da produção, este parece ser o núcleo da mudança.

Além disso, trata-se antes de um modo flexível de realizar a reprodução ampliada do capital do que propriamente de uma acumulação flexível (que, a rigor, seria difícil de conceber, já que as leis da acumulação são bastante rígidas). A ambiguidade se revela na própria oscilação de Harvey entre as expressões "acumulação flexível” - inúmeras vezes empregada e que ficou consagrada - e "modos mais flexíveis de acumulação do capital"294 ou "regime 'flexível' de acumulação" ['flexible' regime of accumulation ${ }^{295}$ ] - mais raras no texto.

Sobretudo a introdução, ainda no mesmo livro, da questão da centralidade das atividades financeiras desregulamentadas, é que encaminhará a análise para a questão do padrão de acumulação. Em $O$ novo imperialismo isso se consolida, quando a abordagem inequivocamente se centra no padrão de acumulação. Harvey pode, então, se valer com mais precisão da expressão “acumulação por espoliação”.

Em Condição pós-moderna, portanto, a crise do fordismo foi apresentada sobretudo como uma crise de "rigidez" - dos investimentos em capital fixo, de planejamento, dos mercados, dos contratos de trabalho, dos compromissos do Estado ${ }^{296}$-, a qual se tentou sanar

\footnotetext{
${ }^{291}$ Ver também PRADO, “Uma nova fase do capitalismo ou um novo modo de produção?”.

${ }^{292}$ PRADO, "Resenha de 'A finança mundializada'”, p. 217-218.

${ }^{293}$ O resumo da "acumulação flexível” feito por Perry Anderson parece corroborar essa proposição, com exceção justamente do último elemento (desregulamentação financeira): "Em resposta, surgiu um novo regime de 'acumulação flexível', à medida que o capital aumentava sua margem de manobra. O novo período encontrava maior flexibilidade nos mercados de trabalho (contratos temporários, mão-de-obra domestica e imigrante), processos de fabricação (mudança de fábricas para outros países, produção a toque de caixa), produção de mercadorias (lotes em consignação) e acima de tudo nas operações financeiras desregulamentadas, ou seja, no mercado de dinheiro e crédito". ANDERSON, As origens da pós-modernidade, p. 94.

${ }^{294}$ HARVEY, Condição pós-moderna, p. 7.

${ }^{295}$ HARVEY, The Condition of Postmodernity, p. 124.

${ }^{296}$ Cf. HARVEY, Condição pós-moderna, pp. 135-136.
} 
ampliando a margem de manobra do capital e reinventando as estratégias de obtenção de mais-valia, principalmente relativa.

A isso ainda se soma o descontentamento daqueles que não se beneficiavam do fordismo mesmo estando nos países centrais (determinados setores econômicos e grupos discriminados por razões raciais, étnicas e de gênero) e do Terceiro Mundo, que não obtinha os mesmos resultados que o centro. Apesar de tudo, o núcleo do modelo fordista teria conseguido se manter, pelo menos, até a recessão de 1973.

A transição para o regime flexível apresentada por Harvey possui as mesmas características já apresentadas aqui e foi motivada, de modo geral, pela crise de sobreacumulação $^{297}$ que eclode no início dos anos 1970. O desafio à hegemonia estadunidense, o fim de Bretton Woods, a desvalorização do dólar e a adoção do câmbio flutuante (que se tornou muito volátil em vários lugares) são citados como algumas das marcas que assinalaram a incapacidade do fordismo-keynesianismo de conter as contradições sistêmicas. O excesso de capacidade das empresas obrigou-as a iniciar um processo de racionalização, reestruturação e intensificação do controle do trabalho, enquanto a crise de 1973, exacerbada pelo choque do petróleo, terminou de solapar o compromisso fordista. Nesse sentido, as décadas de 1970 e 80 foram um período turbulento de reestruturação e ajustamento econômico, social e político.

Mas em que consiste essa acumulação flexível?

A acumulação flexível, como vou chamá-la, é marcada por um confronto direto com a rigidez do fordismo. Ela se apóia na flexibilidade dos processos de trabalho, dos mercados de trabalho, dos produtos e padrões de consumo. Caracteriza-se pelo surgimento de setores de produção inteiramente novos, novas maneiras de fornecimento de serviços financeiros, novos mercados e, sobretudo, taxas altamente intensificadas de inovação comercial, tecnológica e organizacional. ${ }^{298}$

Nesse sentido, ela acarreta fundamentalmente mudanças na organização industrial: as economias de escala são substituídas pela produção de pequenos lotes, o ritmo de inovação aumenta, o tempo de rotação da produção (e do consumo) é reduzido drasticamente, recorrese cada vez mais a terceirizações e deslocalizações, reanimam-se formas de trabalho précapitalistas, fusões e aquisições são intensificadas (com aumento da monopolização), o conhecimento se torna uma mercadoria-chave.

\footnotetext{
${ }^{297}$ Para uma definição sucinta do conceito, ver p. 28, nota 32.

${ }^{298}$ HARVEY, Condição pós-moderna, p. 140.
} 
A flexibilidade envolve, ainda, rápidas mudanças nos padrões de desenvolvimento desigual, crescimento do setor de serviços, e o que Harvey chamou de "compressão do espaço-tempo": os horizontes temporais da tomada de decisões públicas e privadas se estreitam - tendência que Chesnais atribui à financeirização - e as novas tecnologias de comunicação e de transportes diminuem as distâncias relativas entre as regiões do globo.

O aumento de flexibilidade e mobilidade permitiu pressões mais fortes sobre uma força de trabalho enfraquecida pela crise, quebrando sua organização. Uma das estratégias utilizadas foi, a partir da integração entre as regiões do globo, industrializar regiões sem tradição industrial e "reimportar" para o centro as normas e práticas regressivas estabelecidas. As conseqüências são conhecidas: alto desemprego estrutural, aumentos tímidos do salário real, retrocesso das práticas sindicais, reformulação das habilidades de trabalho, reestruturação do mercado de trabalho por contratos mais "flexíveis" (leia-se "precários") 299 , etc.

Harvey afirma ainda que as tensões sempre existentes no capitalismo entre monopolização e competição, centralização e descentralização têm se manifestado de modo essencialmente novo. E um dos desenvolvimentos cruciais para isso é também elemento central da acumulação flexível: "a completa reorganização do sistema financeiro global e a emergência de poderes imensamente ampliados de coordenação financeira"300.

É importante notar como Chesnais e Harvey, autores inseridos em contextos intelectuais distintos (ainda que ancorados em Marx) e sem um diálogo entre si, se põem de acordo sobre a centralidade da questão da finança. Em muitos aspectos, esse processo apontado por Harvey é descrito de forma muito semelhante a como Chesnais apresenta a financeirização. Há, por exemplo, as questões: do fim de Bretton Woods, da desregulamentação e integração dos sistemas financeiros em todo o mundo, da inovação financeira, do entrelaçamento de atividades antes separadas (bancos, corretoras, financiamentos, crédito ao consumidor, etc.), das fusões e incorporações e da submissão dos países do Terceiro Mundo através da crise da dívida. Ocorre, assim, um duplo movimento: a formação de grandes conglomerados financeiros mundiais (em boa parte os "novos atores"

\footnotetext{
${ }^{299}$ A ideologia presente nos termos empregados é uma questão importante. A “lean” production, por exemplo, "alivia/enxuga" o peso para o capital, mas não necessariamente para os trabalhadores. A empresa vê seus ativos se tornarem mais líquidos, no intuito de obter flexibilidade para aproveitar investimentos financeiros vantajosos que se apresentem. Por outro lado, os encargos da "materialidade" da produção ficam por conta das empresas menores e terceirizadas, onde reinam a super-exploração do trabalho, a precarização, etc. sobretudo em regiões de proteção social reduzida.

${ }^{300}$ HARVEY, Condição pós-moderna, p. 152.
} 
mencionados por Chesnais) e a descentralização das atividades e fluxos financeiros por meio da criação de instrumentos e mercados inéditos.

A isso corresponde ainda o crescimento do que Harvey denomina "empreendimentismo com papéis" "301 [paper entrepreneurialism], a tentativa de se obter lucros sem sair da esfera financeira (“acumulação financeira”, nos termos de Chesnais ${ }^{302}$ ), ou seja, através de atividades "que não se restrinjam à produção pura e simples de bens e serviços" ${ }^{~} 303$. Isso inclui ganhos em especulação com ativos, sobretudo moedas (e cada vez mais uma gama enorme de derivativos), a apropriação de ativos de outras corporações, entre outras operações que em si não geram valor, mas fazem mudar de mãos valores já gerados ou que ainda precisam ser gerados, no caso do capital fictício. Harvey argumenta ainda que o empreendimentismo com papéis se tornou tão "lucrativo" que os empregos/negócios mais rentáveis nos EUA estariam nas esferas legal e financeira da ação corporativa e não na administração da produção.

O fato de a acumulação flexível destacar, mais do que o fordismo, o capital financeiro como poder coordenador (no que se pode incluir a desintermediação financeira), com as contradições que isso engendra, constitui um dos elementos de distinção entre os dois regimes de acumulação. Harvey observa que se o equilíbrio entre o poder financeiro e o poder do Estado sempre fora frágil, o fim do fordismo-keynesianismo sem dúvida fortaleceu o capital financeiro $^{304}$, deixando o Estado em uma posição mais delicada: deve regular o capital em nome dos interesses da nação, ao mesmo tempo que é compelido, também no interesse nacional, a criar um clima propício para os negócios a fim de atrair o capital financeiro internacional. Ele fica igualmente mais vulnerável a crises fiscais e aos constrangimentos do dinheiro mundial, ainda que conservando a capacidade de disciplinar o trabalho e de intervir nos fluxos dos mercados financeiros.

Ademais, a potencialidade de formação de "crises autônomas e independentes"305 é muito mais elevada, e a instabilidade e fluidez das operações podem ser associadas "ao

\footnotetext{
${ }^{301}$ HARVEY, Condição pós-moderna, p. 154.

${ }^{302}$ Cf. CHESNAIS, “O capital portador de juros (...)”, p. 37.

${ }^{303}$ HARVEY, op. cit., p. 154.

${ }^{304}$ Nesse sentido, é curiosa sua afirmação de que: "inundado pela liquidez e perturbado por um endividamento que saiu do controle a partir de 1973, o sistema financeiro mundial conseguiu mesmo assim fugir de todo controle coletivo" - Ibidem, p. 154 (itálico nosso). O movimento que se processou, como bem mostra Chesnais, foi exatamente o de subtração do sistema financeiro ao controle coletivo. As crises e instabilidades foram fatores que auxiliaram nesse processo, e não um obstáculo a ele.

305 Note-se que Harvey não esclarece o que seriam essas crises "autônomas e independentes", embora se possa associá-las às crises financeiras "autênticas" de Chesnais. Desse modo, a mesma ponderação quanto à falta de precisão desta expressão se aplicaria (ver p. 85, nota 232).
} 
aumento dessa capacidade de dirigir os fluxos de capital para lá e para cá de maneiras que parecem desprezar as restrições de tempo e de espaço, 306 . Nesse sentido, o que talvez haja de mais interessante na formulação de Harvey é a percepção de que a proliferação desses novos mercados futuros (e de derivativos em geral, pode-se acrescentar) e o aumento do empreendimentismo com papéis "descontaram o tempo futuro no tempo presente" ${ }^{\text {,307 }}$ de modo surpreendente. As inovações tecnológicas que reduziram as distâncias geográficas e permitiram a realização de operações em tempo real em qualquer parte do globo abriram espaço para o entrelaçamento de uma diversidade de atividades em um emaranhado difícil de deslindar. A enorme formação de capital fictício a que esse processo deu origem revela, de fato, como o futuro está sendo "trazido" para o presente sem que haja garantias de que isso possa ser efetivado ${ }^{308}$.

Todas essas transformações levam Harvey a afirmar que "o que parece realmente especial no período iniciado em 1972 é o florescimento e transformação extraordinários dos mercados financeiros"309. Tal especificidade é justificada pelo argumento de que em outras fases do capitalismo, tais como entre 1890 e 1929, o capital financeiro pode até adquirir uma posição fundamental, mas acaba perdendo-a nas crises especulativas. Já na atual fase, o sistema financeiro propiciou grande parte da flexibilidade geográfica e temporal da acumulação de capital, tendo a inovação financeira sido um requisito tão indispensável para a superação da "rigidez", que parece ter primazia sobre as próprias transformações que levaram efetivamente à flexibilidade:

Estou, portanto, tentado a ver a flexibilidade conseguida na produção, nos mercados de trabalho e no consumo antes como um resultado da busca de soluções financeiras para as tendências de crise do capitalismo do que o contrário. Isso implicaria que o sistema financeiro alcançou um grau de autonomia diante da produção real sem precedentes na história do capitalismo, levando este último a uma era de riscos financeiros igualmente inéditos. ${ }^{310}$

Aí parece residir, portanto, uma pista para a solução de certas imprecisões contidas no conceito de "acumulação flexível". Ao longo do livro, é difícil determinar quais características ou processos possuem precedência sobre quais, já que há uma série de fatores

\footnotetext{
${ }^{306}$ HARVEY, Condição pós-moderna, p. 155.

${ }^{307}$ No original: "Discounting time future into time present" - HARVEY, The Condition of Postmodernity, p. 161

308 Em virtude disso, "surge toda espécie de meio técnico para evitar choques do futuro", tais como: terceirização, flexibilidade de contratação, mercados futuros, securitização. - HARVEY, Condição pós-moderna, p. 263.

${ }^{309}$ Ibidem, p. 181.

${ }^{310}$ Ibidem, p. 181 (itálico nosso).
} 
sobrepostos ou paralelos que compõem a acumulação flexível, todos decorrências diretas ou indiretas do movimento gerado pela crise de sobreacumulação dos anos 1970. Porém, as duas citações acima reforçam o argumento de Chesnais quanto à importância dessa virada que coloca a dominância financeira como o elemento central na caracterização do capitalismo contemporâneo. Desse modo, se Harvey define inicialmente o regime flexível focando a forma de produção de mercadorias (cerne da flexibilização), o conjunto total das transformações que ele aponta - a questão financeira em especial - revela que também se trata de fato de uma mudança no padrão de acumulação do capital, ainda que não seja propriamente no sentido de "flexibilizar" a acumulação, mas talvez de "financeirizar" seus processos.

No final da parte II de Condição pós-moderna, são anunciadas duas conclusões "básicas (embora provisórias)"’311. Primeiro, a reafirmação de que se há algo peculiar atualmente, isso deve ser buscado nos aspectos financeiros da organização capitalista. Em segundo lugar, os elementos para que se obtenha alguma estabilidade em médio prazo no atual regime de acumulação devem ser buscados em novas rodadas de ajuste espacial e temporal.

Para se entender o que são os ajustes espaço-temporais ${ }^{312}$ e sua relação com a financeirização, é preciso retornar à questão da sobreacumulação do capital. Harvey destaca três características definidoras do capitalismo:

a) ele é sempre orientado para o crescimento, independentemente das conseqüências sociais, políticas, geopolíticas ou ecológicas que isso engendra;

b) o crescimento real só pode ocorrer através da exploração do trabalho vivo empregado na produção de mercadorias, exigindo, assim, o controle do trabalho pelo capital;

\footnotetext{
${ }^{311}$ HARVEY, Condição pós-moderna, p. 184.

${ }^{312}$ Harvey alterna entre os termos "ajuste/reparo" [fix] e "deslocamentos" [displacements], dando a entender que o primeiro seria efeito do segundo. Porém, eles podem ser considerados sinônimos, conforme se depreende da passagem seguinte: "O deslocamento espacial compreende a absorção pela expansão geográfica do capital e do trabalho excedentes. Esse 'reparo espacial' (como o denominei alhures) do problema da superacumulação promove a produção de novos espaços dentro dos quais a produção capitalista possa prosseguir" - Ibidem, p. 172 (itálicos nossos).
} 
c) o capitalismo é tecnológica e organizacionalmente dinâmico, estando sempre em processo de inovação.

Contudo, Marx teria demonstrado que essas três condições do modo de produção capitalistas são contraditórias entre si, levando a crises e a fases periódicas de sobreacumulação do capital ${ }^{313}$.

Desse modo, a tendência à sobreacumulação nunca pode ser superada no capitalismo. O que se pode é utilizar métodos para conter, absorver, administrar essa tendência evitando colocar em risco a ordem social. Harvey apresenta três das opções de que a burguesia dispõe para tanto. Primeiramente, pode desvalorizar mercadorias, a capacidade produtiva ou o dinheiro $^{314}$, por vezes através da destruição direta. Esta é a faceta destrutiva irracional do capitalismo para retomar o crescimento e possui alto custo político, atingindo tanto capitalistas quanto a classe trabalhadora. Devido à sua brutalidade, as desvalorizações não podem ser sustentadas por muito tempo, embora políticas deflacionárias administradas sejam mais sutis e se constituam em uma opção importante. A segunda forma é forjar um controle macroeconômico através da institucionalização de algum sistema de regulação que equilibre as forças que causam a sobreacumulação, tal como se conseguiu até certo ponto no fordismokeynesianismo. Contudo, as decisões econômicas e políticas nem sempre são (ou podem ser) conscientemente dirigidas para esse fim específico. O terceiro modo de tentar contornar a sobreacumulação é a absorção desta por meio do deslocamento espacial ou temporal, que, para Harvey, se constitui em um instrumento mais duradouro, embora mais problemático.

De modo geral, o deslocamento temporal pode envolver dois processos: o investimento em projetos de longo prazo (ex. infra-estruturas), desviando recursos presentes para a exploração de usos futuros, ou então a aceleração do ciclo produtivo para que um ano possa absorver a capacidade excedente do ano anterior. Mas, para isso, é preciso haver disponibilidade de crédito e a formação de capital fictício. Este é exatamente o capital que circula hoje, mas sem base material, ficando condicionado à efetiva produção futura de valor correspondente. Consequentemente, o deslocamento temporal é um paliativo de curto prazo, já que apenas adia o problema ou exige rotações do capital cada vez mais aceleradas.

Com a capacidade de multiplicação do capital fictício observada atualmente, é possível cogitar que o deslocamento temporal ganha uma dimensão nova e importante, ainda

\footnotetext{
${ }^{313}$ Cf. HARVEY, Condição pós-moderna, pp. 166-170.

${ }^{314}$ A crise de sobreacumulação pode se manifestar de diversos modos: mercadorias acumuladas nos estoques (superprodução), capacidade produtiva ociosa, excesso de dinheiro para empréstimo, alto índice de desemprego, etc., demandando diferentes modos de se lidar com ela. Cf. HARVEY, Limits to Capital, p. XXIV (Introduction to the 2006 Verso edition).
} 
mais porque, nos mercados financeiros, os títulos trocam de mãos inúmeras vezes e sofrem oscilações de preço de modo bastante autônomo em relação ao processo real de produção. Mesmo que um empreendimento só dê retorno muito tempo depois de iniciado, já se especula com a compra e venda do capital fictício que ele origina, "presentificando" os resultados futuros. Evidentemente, essa também não seria uma solução de fato, já que o efeito normalmente é a criação de bolhas que, ao estourarem, geram novas crises ao não se confirmarem os resultados esperados de criação de valor.

Em $O$ novo imperialismo, Harvey faz um comentário importante sobre o ajuste temporal. Ele divide a possibilidade de investimentos em setor primário (domínio da produção e do consumo imediatos), secundário (capital fixo e formação de fundo de consumo) e terciário (gastos sociais, de pesquisa e desenvolvimento). O ajuste temporal consiste exatamente em transferir os fluxos excedentes de capital do setor primário para os demais. Se os investimentos nos setores secundários e terciários contribuírem para a melhora futura da produtividade do capital, o capital sobreacumulado pode voltar ao setor primário, aliviando, pelo menos temporariamente, o problema de sobreacumulação. Caso ocorra sobreinvestimentos nos setores secundários e terciários, podem ser desencadeadas crises mais gerais, devido aos excedentes de, por exemplo, habitações, instalações produtivas e de capacidade no sistema educacional. Porém, mesmo diante do fracasso de determinados empreendimentos, esses investimentos podem ser de grande valia, pois deixam valores de uso físicos atrás de si. Isso pode ser particularmente atraente ao capital financeiro, que os compra por um preço bem abaixo de seu valor (muitas vezes dando vazão a um capital sobreacumulado) e lhes dá posteriormente um destino lucrativo.

A alocação equilibrada de investimentos nos três setores depende crucialmente, segundo Harvey, da mediação de instituições estatais e financeiras como poderes coordenadores. Essa mediação se processa por meio da capacidade de conceder crédito de forma a tornar determinados investimentos mais atrativos que outros. Consequentemente, há geração de capital fictício que deve ser "realizado" com o aumento futuro da produtividade. Caso isso não ocorra, pode haver ondas de desvalorização, inclusive o estouro de bolhas financeiras. Embora Harvey não comente a respeito, levando-se em conta o que diz Chesnais, no ambiente altamente especulativo criado pela financeirização, com excesso de circulação de capital fictício, é de se esperar que boa parte deste não encontre seu lastro produtivo, tornando os desequilíbrios mais recorrentes e esse tipo de ajuste temporal mais arriscado. 
Já o deslocamento espacial envolve a absorção de capital e trabalho excedentes por meio da expansão geográfica. Significa a agregação de novos espaços, ainda não dominados pelo capitalismo (ou não completamente), onde a produção possa prosseguir. O deslocamento espacial, embora de forma menos visível, não deixa de estar relacionado aos processos financeiros. Segundo Harvey: "também aqui o sistema de crédito e a formação de capital fictício, sustentados pelo poder fiscal, monetário e, quando preciso, militar do Estado, se tornam vitais influências mediadoras" ${ }^{315}$. Os altos custos ou riscos de se iniciar um empreendimento capitalista em outra localidade levam à necessidade de crédito para tais operações e, sobretudo, de estímulos estatais. A especulação, logo a geração de mais capital fictício, entra também como um componente importante, devido às incertezas do processo.

Contudo, a não ser que haja a ocupação constante de novos espaços, o que dificilmente ocorre em um ritmo sustentado, essa solução também é limitada. Além disso, trata-se de uma estratégia profundamente contraditória, na medida em que, cedo ou tarde, as novas áreas de valorização criadas entrarão em competição com as regiões antigas e se defrontarão igualmente com fatores de sobreacumulação, necessitando solucioná-los - muitas vezes tendo como resultado a desvalorização do capital fictício anteriormente criado ${ }^{316}$.

O que é mais eficaz e mais comumente empregado, todavia, são as estratégias que combinam ambos os aspectos, ou seja, os deslocamentos espaço-temporais. O exemplo apresentado é o de levantamento de dinheiro em algum mercado de capital europeu para a construção de infra-estruturas na América Latina. De acordo com a interpretação de Harvey, o fordismo recorreu principalmente a deslocamentos espaço-temporais para resolver seus problemas de sobreacumulação. Portanto, de certo modo a crise do fordismo pode ser interpretada como um esgotamento das possibilidades de lidar com a sobreacumulação através de deslocamentos em moldes fordistas, devido a: acúmulo de dívidas, inflação por emissão de moeda, competitividade crescente dos novos centros de acumulação, entre outros fatores. Isso de todo modo ocorreria em algum momento, já que não é possível resolver de modo definitivo o problema de sobreacumulação somente através de deslocamentos espaço-temporais e sem desvalorizações do capital e da força de trabalho.

A acumulação flexível teria, pois, se constituído após fases de desvalorização de ativos, que levaram a uma combinação renovada das duas estratégias de obtenção de lucro mais-valias absoluta e relativa: aumento das jornadas e redução de salários, por um lado,

\footnotetext{
${ }^{315}$ HARVEY, Condição pós-moderna, p. 172.

${ }^{316}$ Ou tendências imperialistas.
} 
mudança organizacional e tecnológica, por outro. Além disso, a partir da nova configuração do setor financeiro, é razoável supor que o empreendimentismo com papéis se confirmou como estratégia para se tentar contornar os fatores de sobreacumulação de capital ainda presentes. As operações nos mercados financeiros podem, assim, ser interpretadas como uma espécie de deslocamento temporal particularmente contraditório: permitem obter benefícios do ponto de vista individual, ao antecipar lucros futuros ou mesmo "ilusórios" (especulativos), mas não resolvem os problemas gerais de sobreacumulação, podendo inclusive agravá-los.

A relação do tempo e do espaço com a financeirização possui ainda outros aspectos. A tese geral de Condição pós-moderna, formulada no início do livro, é de que há "algum tipo de relação necessária entre a ascensão de formas culturais pós-modernas, a emergência de modos mais flexíveis de acumulação do capital e um novo ciclo de 'compressão do tempo-espaço' na organização do capitalismo",317. Se Harvey não concebe essa relação de forma causal, o que contrariaria a dialética marxista, ele revela uma visão materialista ${ }^{318}$. Desse modo, as "novas maneiras dominantes pelas quais experimentamos o tempo e o espaço" ${ }^{319}$, bem como todo o conjunto de transformações sócio-culturais colocadas sob a rubrica do pós-modernismo, de alguma forma parecem ser embasadas pela nova organização econômica que se impõe a partir da forte crise de sobreacumulação do capital dos anos 1970.

\footnotetext{
${ }^{317}$ HARVEY, Condição pós-moderna, p. 8.

${ }^{318}$ Este na verdade também é um ponto ambíguo no livro - que talvez esteja na raiz da discussão sobre o termo “acumulação flexível”. No Prefácio, encontramos a seguinte passagem, reforçando a perspectiva materialista: "O restante do trabalho examina (...) os fundamentos político-econômicos, antes de explorar a experiência do espaço e do tempo como vínculo mediador singularmente importante entre o dinamismo do desenvolvimento históricogeográfico do capitalismo e complexos processos de produção cultural e transformação ideológica" - Ibidem, p. 9 (itálico nosso). Adicionalmente, tem-se que "nem o tempo nem o espaço podem ter atribuídos significados objetivos sem se levar em conta os processos materiais" e que "dessa perspectiva materialista, podemos afirmar que as concepções do tempo e do espaço são criadas necessariamente através de práticas e processos materiais que servem à reprodução da vida social” - Ibidem, p. 189.

Por outro lado, no capítulo 17, a compressão do tempo-espaço parece possuir certa precedência: "Desejo sugerir que temos vivido nas duas últimas décadas uma intensa fase de compressão do tempo-espaço que tem tido um impacto desorientador e disruptivo sobre as práticas político-econômicas, sobre o equilíbrio do poder de classe, bem como sobre a vida social e cultural” - Ibidem, p. 257 (itálico nosso). Contudo, parece difícil compreender por que adviria uma fase de compressão do tempo-espaço sem que uma mudança de ordem material a desencadeasse ou lhe desse suporte. Desse modo, embora só seja possível separar esses elementos de modo analítico, já que fazem parte de um mesmo processo, e não seja adequado estabelecer conexões propriamente causais, parece mais plausível considerar que a crise de sobreacumulação do capital e as mudanças "materiais" dela decorrentes sejam o fator dinamizador das demais transformações.

${ }^{319}$ Ibidem, p. 8.
} 
Segundo Harvey, as compressões do tempo-espaço não são, contudo, uma especificidade da pós-modernidade. Derivam das exigências imanentes da acumulação de capital, uma característica do capitalismo em geral, na medida em que este tem se caracterizado por uma aceleração do ritmo de vida e pela redução das barreiras espaciais (distâncias relativas). Elas são então definidas como: "processos que revolucionam as qualidades objetivas do espaço e do tempo a ponto de nos forçarem a alterar, às vezes radicalmente, o modo como representamos o mundo para nós mesmos”320, ou seja, experiências profundas, capazes de provocar reações sociais, culturais e políticas.

Assim, o próprio nascimento do modernismo ${ }^{321}$ teve a ver com um processo de compressão do tempo-espaço que rompeu de vez com o paradigma feudal. Isso pode ser remetido às considerações que Marx e Engels expõem em $O$ manifesto comunista ${ }^{322}$, no qual fazem um denso resumo histórico da constituição da modernidade, ou seja, da passagem do feudalismo para o capitalismo. Nesse texto, podem-se apreender três grandes tendências expansivas do capitalismo ${ }^{323}$ : uma expansão que se poderia chamar de imanente (revolução constante dos meios de produção e das técnicas de trabalho), outra de intensiva (para além da esfera da produção, englobando outras esferas da sociedade) e ainda uma outra que se poderia definir como extensiva (ampliando o escopo do capitalismo, ao subordinar os setores précapitalistas tanto interna como externamente). $\mathrm{O}$ resultado de todas essas tendências, aliado aos processos próprios à acumulação de capital que vão se consolidando, é exatamente uma aceleração tanto da percepção do tempo, como da integração de regiões do globo antes isoladas.

Nesse sentido, a suposição de Harvey é de que "o pós-modernismo é alguma espécie de resposta a um novo conjunto de experiências do espaço e do tempo, uma nova rodada da 'compressão do tempo-espaço", 324 , no curso da qual se busca, mais intensamente, "aniquilar o espaço pelo tempo"325 e descontar o futuro no presente. Para ilustrar alguns dos componentes desse processo, são retomados aspectos anteriormente mencionados aqui: a implementação de novas formas organizacionais e de novas tecnologias que aceleraram o tempo de rotação da

\footnotetext{
${ }^{320}$ HARVEY, Condição pós-moderna, p. 219.

${ }^{321} \mathrm{O}$ modernismo, para Harvey, é o movimento sócio-cultural associado à emergência da modernidade como um "projeto" a partir do século XVIII. Embora a transição do feudalismo para o capitalismo comece dois séculos antes (e algumas de suas conseqüências sociais e culturais já começassem a se fazer sentir), o iluminismo é um ponto importante de inflexão na trajetória rumo ao modernismo. Para mais detalhes, ver HARVEY, Condição pós-moderna, cap. 2.

${ }^{322}$ MARX e ENGELS, $O$ manifesto comunista.

${ }^{323}$ Cf. MUSSE, "Introdução ao Manifesto Comunista".

${ }^{324}$ HARVEY, op. cit., p. 256.

${ }^{325}$ Expressão de Marx retomada por Harvey: "The annihilation of space by time" - MARX, Grundrisse, p. 524.
} 
produção, da troca e do consumo; o crescimento do setor de serviços (cujo tempo de consumo é mais curto); o privilégio do curto-prazo na tomada de decisões; fusões e aquisições (acúmulo imediato de capital pela centralização); a preocupação maior com as vantagens localizacionais relativas; o rápido desenvolvimento de tecnologias de transporte e de comunicação; o recurso à deslocalização industrial; e, como não poderia deixar de ser, o crescimento e ganho de importância dos serviços e mercados financeiros ${ }^{326}$.

Vê-se, desse modo, que o conjunto de transformações representado pela financeirização, tal como concebido em mais detalhes por Chesnais, e essa nova rodada de compressão do tempo-espaço parecem estar fortemente imbricados. Além disso, as exigências e o modo de operação do capital financeiro e das instituições e atores sociais a ele associados também estão visivelmente vinculados a muitas das características da pós-modernidade listadas por Harvey ${ }^{327}$ : descentralização, jogo, imaterialidade, dispersão, ficção, autoreferência, reprodução eletrônica, desregulação, efemeridade, etc. Podendo-se ainda acrescentar outras, presentes ao longo do livro: instantaneidade, aceleração, volatilidade, descartabilidade, mobilidade.

Nesse sentido, Harvey argumenta que:

Situando essa condição [pós-moderna] em seu contexto histórico, como parte de uma história de ondas sucessivas de compressão de tempo-espaço geradas pelas pressões da acumulação de capital - com seus perpétuos esforços de aniquilação do espaço por meio do tempo e de redução do tempo de giro -, podemos ao menos levá-la para o âmbito de condição acessível à análise e interpretação materialista histórica. $^{328}$

Seguindo, pois, o raciocínio materialista indicado, parece correto considerar que, de forma geral, a atual rodada de compressão do tempo-espaço e as práticas culturais emergentes na pós-modernidade a ela associadas remontam a uma mudança "material" da qual um dos pilares essenciais é a centralidade adquirida pelo capital financeiro nos processos gerais de reprodução do capital e suas conseqüências.

\footnotetext{
${ }^{326}$ Cf. HARVEY, Condição pós-moderna, cap. 17.

${ }^{327}$ Cf. Ibidem, p. 304 (Tabela 4.1).

${ }^{328}$ Ibidem, p. 276.
} 
Por fim, convém ainda comentar as considerações de Harvey sobre o significado histórico da pós-modernidade e da acumulação flexível e, em particular, sobre a relação entre modernismo e pós-modernismo.

Antes de tudo, Harvey enfatiza que as invariantes do capitalismo, tal como delineadas por Marx, ainda estão claramente presentes na atualidade, de modo a descartar qualquer interpretação de que esteja ocorrendo a transição para uma era "pós-capitalista", "pósindustrial" ou algo similar ${ }^{329}$. Por outro lado, reduzir a acumulação flexível a uma "versão mais retumbante da mesma velha história do capitalismo de sempre" ${ }^{\circledR 30}$ é considerada uma avaliação simplista. Desse modo, ele reconhece implicitamente a importância da preocupação da escola da regulação em diferenciar as fases do capitalismo, apesar de considerar insuficientes seus esforços para compreender os mecanismos e a lógica das transições entre os períodos. Donde os instrumentos teóricos construídos por Marx serem invocados para empreender a análise ${ }^{331}$.

Nesse sentido, embora Harvey defenda a existência de uma configuração do capitalismo que denomina acumulação flexível, não deixa de relativizar sua abrangência: "as tecnologias e formas organizacionais flexíveis não se tornaram hegemônicas em toda parte" 332 , indicando que o fordismo ainda possui penetração. O reconhecimento dessa restrição, embora possa ser atribuído ao fato de que talvez em 1989 o processo de flexibilização ainda não estivesse tão avançado, provavelmente se deve também a uma limitação dessa modalidade de periodização do capitalismo que privilegia as mudanças nos processos produtivos. Nem o fordismo, nem a acumulação flexível podem se tornar uma unanimidade social. Sempre haverá a convivência de diferentes modos de organização do processo produtivo, cada um com suas configurações e consequiências específicas, o que dificulta a formulação de generalizações. Nesse sentido, uma abordagem que enfatize o padrão de acumulação (da qual as mudanças na forma de produção façam parte, mas não sejam o cerne da distinção entre os regimes), e mais especificamente a de Chesnais em relação à dominância financeira, parece possuir maiores condições de ser mais abrangente na análise ${ }^{333}$.

\footnotetext{
${ }^{329}$ Cf. HARVEY, Condição pós-moderna, pp. 8 e 117.

${ }^{330}$ Ibidem, p. 176.

${ }^{331}$ Cf. Ibidem, p. 164.

${ }^{332}$ Ibidem, p. 179.

${ }^{333}$ Note-se que Chesnais critica a fetichização que toma o processo de financeirização por irreversível, coerente e estável. Contudo, não parece haver a mesma preocupação que Harvey em alertar para uma parcialidade ou
} 
Isso porque a financeirização conforma o funcionamento do sistema em geral. Ela não precisa estar efetivamente presente na estruturação de todas as empresas (ex. nem todas precisam estar mergulhadas em atividades financeiras, estar cotadas na Bolsa, ser comandadas por um conselho que vise à maximização dos dividendos, etc.) para dominar a dinâmica capitalista. Hoje, virtualmente todos os empreendimentos capitalistas estão, direta ou indiretamente, inseridos no contexto da financeirização e submetidos a ela, devido a fatores como: ter relações comerciais com grupos "financeirizados" (sobretudo na posição de terceirizado); ser dependente do sistema de crédito; ser afetado por oscilações do câmbio, dos juros e da inflação (alvos muitas vezes de especulação e influenciados por agentes financeiros); e ser vulnerável aos efeitos de crises financeiras e instabilidades (atualmente mais freqüentes e geralmente conseqüência da ação de grandes agentes financeiros) que atingem a economia como um todo. Em suma, embora tratar a forma de produção e o padrão de acumulação separadamente comprometa o entendimento, vê-se que, no primeiro caso (Harvey), o fato de o predomínio da organização flexível não ser absoluto pode dificultar a formulação de generalizações e demandar mais ressalvas na análise. Já no segundo (Chesnais), a hegemonia peculiar sobre o funcionamento do capitalismo representada pela dominância financeira na economia faz com que seus efeitos sejam sentidos mais amplamente, permitindo conclusões mais gerais.

Essa idéia é reforçada pelas observações de Harvey sobre a relação entre dinheiro, tempo e espaço. Na parte III de Condição pós-moderna, após uma série de considerações sobre as categorias de tempo e espaço, ele ensaia um "argumento geral": "nas economias monetárias em geral e na sociedade capitalista em particular, a intersecção do domínio sobre o dinheiro, o tempo e o espaço forma um nexo substancial de poder social que não podemos nos dar ao luxo de ignorar" ${ }^{334}$. Desenvolvendo esse ponto, afirma que o domínio do tempo e do espaço é crucial na busca do lucro, ao mesmo tempo que o dinheiro pode ser usado para dominar o tempo e o espaço. Ou seja, "quem define as práticas materiais, as formas e os sentidos do dinheiro, do tempo ou do espaço fixa certas regras básicas do jogo social”,335.

Todavia, esse triângulo não se mostra equilibrado, já que, mais adiante no texto, defende-se que a monetização das relações sociais transforma as qualidades do tempo e do espaço, e que modificações das qualidades do espaço e do tempo podem advir da busca de

restrição do alcance do fenômeno (a não ser a ressalva de que a financeirização está presente em grau e forma diferentes nos países periféricos em relação aos centrais).

${ }^{334}$ HARVEY, Condição pós-moderna, p. 207.

${ }^{335}$ Ibidem, p. 207. 
objetivos monetários. Ora, se o dinheiro possui tal ascendência sobre a vida social, é possível compreender melhor a idéia de Chesnais de que a finança adquire proeminência social e passa a comandar os processos de valorização do capital. O controle sobre o dinheiro, ou sobre o capital monetário, exercido por ela, confere-lhe o predomínio, mesmo que indireto, sobre o funcionamento geral do capitalismo.

Consequentemente, conforme aventado acima, a finança é capaz de fazer notar sua influência mesmo sem estar diretamente presente na organização interna de todas as empresas ou na estruturação de um setor econômico específico. Assim, a periodização do capitalismo baseada na dominância financeira figura como mais abrangente que aquela baseada nas formas assumidas pela produção de mercadorias (embora ambas sejam, a seu modo, incompletas).

Para ser coerente com sua análise mais centrada na forma de produção, Harvey argumenta que dois regimes de acumulação, e seus respectivos modos de regulação, podem conviver. As fronteiras estanques entre o modernismo e o pós-modernismo são, então, relativizadas e sua convivência é interpretada como expressão das contradições internas do capitalismo:

Podemos dissolver as categorias do modernismo e do pós-modernismo num complexo de oposições que exprime as contradições culturais do capitalismo. Assim, vemos as categorias do modernismo e do pós-modernismo como reificações estáticas impostas à interpenetração fluida de oposições dinâmicas. ${ }^{336}$

De modo análogo, como visto, Chesnais coloca em dúvida a existência de um modo de regulação que estabilize o atual regime de acumulação financeirizado. Este é descrito como sendo imperfeito, instável, contraditório e, talvez, transitório. À diferença de Harvey, contudo, essa situação não parece ser interpretada como fruto da convivência de dois regimes de acumulação, mas originar-se da contradição insuperável entre esfera financeira e produtiva. A dominância financeira não elimina (nem poderia) os processos produtivos, de modo que é provavelmente a relação contraditória entre finanças e produção que se reflete numa realidade social conflituosa. Nesse sentido, tudo indica que as contradições existentes são internas ao novo regime de acumulação e não entre dois regimes que conviveriam.

${ }^{336}$ HARVEY, Condição pós-moderna, p. 305. 


\section{CAPÍTULO 5 - FINANCEIRIZAÇÃO E NEOLIBERALISMO}

A Condição pós-moderna procura estabelecer as relações entre um conjunto de mudanças "materiais" importantes do capitalismo e a emergência de novos traços sócioculturais chamados de "pós-modernos" - estreitamente associados a uma nova forma, mais "comprimida", de percepção do espaço e do tempo. Uma descrição detalhada desse processo está contida na caracterização do regime de acumulação "flexível” que nasce nos anos 1970. Contudo, pouca atenção é concedida à definição propriamente de um "modo de regulação" que acompanhasse esse novo regime de acumulação, em parte pelo caráter recente do fenômeno e também pela incerteza quanto à consolidação desse novo regime ${ }^{337}$.

Dessa maneira, se para Harvey o modo de regulação associado ao regime fordista possui como um de seus elementos centrais o "keynesianismo", e este chega a termo junto com aquele, surge a questão de que outro arcabouço regulatório deveria substituí-lo. A resposta do próprio autor veio em um livro publicado cerca de quinze anos mais tarde ${ }^{338}$. Embora já afastado dos conceitos e vocabulário da escola da regulação, ele descreve o "neoliberalismo" como o paradigma político - em sentido amplo, envolvendo valores, instituições, forma de organização estatal, relação entre classes sociais, etc. - que ascende paralelamente à acumulação flexível. Presume-se, portanto, que o neoliberalismo corresponderia de certo modo a uma espécie de "modo de regulação" do regime de acumulação flexível - substituindo o keynesianismo.

O neoliberalismo como doutrina político-econômica já existia desde a metade do século XX. Não obstante, Harvey situa nos anos 1978-1980 o "ponto de ruptura

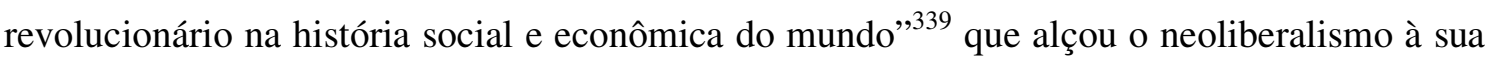
posição proeminente. Foram os políticos Ronald Reagan e Margareth Thatcher os pivôs de

\footnotetext{
${ }^{337} \mathrm{Na}$ mesma passagem em que coloca em dúvida a perenidade do regime de acumulação nascente, Harvey esboça o que talvez seria o modo de regulação correspondente, no qual se incluiriam as mudanças sócio-culturais (pós-modernismo): "não está claro se os novos sistemas de produção e de marketing (...) garantem ou não o título de um novo regime de acumulação nem se o renascimento do empreendimentismo e do neoconservadorismo, associado com a virada cultural para o pós-modernismo, garante ou não o título de um novo modo de regulação" - HARVEY, Condição pós-moderna, p. 119.

${ }^{338}$ Cf. HARVEY, O neoliberalismo: história e implicações.

${ }^{339}$ Ibidem, p. 11.
} 
um processo que transformou os princípios do neoliberalismo - até então secundários nos meios políticos - em diretrizes centrais da administração econômica ${ }^{340}$.

Como qualquer outro modo de pensar, argumenta Harvey, o neoliberalismo organiza um aparato conceitual que mobiliza as pessoas a partir de valores, sensações, desejos, etc. de modo a se converter de proposições externas a princípios alojados internamente, forjando um "senso comum". O liberalismo político clássico forneceu a base desse aparato conceitual, apelando aos "ideais políticos da dignidade humana e da liberdade individual"341, bastante sedutores. Defendia-se, assim, que o bem-estar geral seria alcançado por intermédio da liberdade de empreendimento individual em um contexto de garantia da propriedade privada e da liberdade de mercado. Não é preciso dizer que os valores aí implicados são caros ao Ocidente e também fariam parte dos movimentos oposicionistas da União Soviética e da China Comunista (mas também, não se pode esquecer, da justificação da guerra, como no Iraque).

Embora se trate de valores clássicos bastante abstratos, é possível aproximá-los, retomando Condição pós-moderna, do "estilo" pós-moderno. Liberdade de consumo, de ser e pensar o que se queira, de se reinventar a todo momento - mas também a flexibilidade de contratar e demitir sem dificuldades, de produzir onde se queira... - podem ser interpretadas como variações específicas dessa liberdade mais geral invocada pelo neoliberalismo:

\footnotetext{
A neoliberalização precisava, política e economicamente, da construção de uma cultura populista neoliberal fundada no mercado que promovesse o consumismo diferenciado e o libertarianismo individual. No tocante a isso, ela se mostrou mais que compatível com o impulso chamado 'pós-moderno'. ${ }^{342}$
}

Ainda assim, não está explicado por que a virada neoliberal ocorre no final dos anos 70 e não décadas antes. Fundamentalmente, segundo Harvey, a razão é a mesma que levou à emergência do regime flexível de acumulação, a saber: a crise de sobreacumulação de capital que assinalou o esgotamento do fordismo-keynesianismo. O "liberalismo embutido" "343, como

\footnotetext{
${ }^{340}$ Para Harvey, na avaliação do sucesso de Reagan e Thatcher deve-se "enfatizar o modo como eles se apropriaram do que eram até então posições políticas, ideológicas e intelectuais minoritárias e as transformaram na corrente majoritária" - HARVEY, O neoliberalismo, p. 72.

${ }^{341}$ Ibidem, p. 15.

${ }^{342}$ Ibidem, p. 52.

343 Embedded liberalism, no original, é a expressão que Harvey diz ser comumente usada para designar "essa forma de organização político-econômica (...) [que sinaliza] como os processos de mercado e as atividades empreendedoras e corporativas vieram a ser circundados por uma rede de restrições sociais e políticas e um ambiente regulatório que às vezes restringiu mas em outros casos liderou a estratégia econômica e industrial" Ibidem, pp. 20-21.
} 
Harvey o denomina em $O$ neoliberalismo, que havia propiciado elevadas taxas de crescimento econômico aos países centrais nas décadas de 1950-60, por meio de políticas fiscais e monetárias keynesianas e de determinados "compromissos de classe" entre capital e trabalho, não funcionava mais.

A crise de sobreacumulação constitui um fator fundamental, abrindo caminho para mudanças políticas importantes com a finalidade de restabelecer as condições propícias para a acumulação. As relações entre a dinâmica política e as condições econômicas, entretanto, são mais complexas. Harvey lembra que houve um tipo de resposta, de partidos socialistas e comunistas europeus, que propunha aprofundar o controle e a regulação estatal. No entanto, essas experiências fracassaram, sendo preteridas em benefício da saída neoliberal, em grande medida devido ao próprio esgotamento desse tipo de solução, mas também em razão das conseqüências sócio-econômicas da crise.

O fordismo se assentou em certa restrição do poder econômico das classes mais altas em benefício de uma participação maior dos trabalhadores na renda nacional ${ }^{344}$. Tal restrição parecia aceitável enquanto a economia crescia de forma sustentada e os capitalistas embolsavam lucros crescentes. No entanto, avalia Harvey, quando a crise se abateu sobre o capitalismo mundial e os lucros e dividendos começaram a cair, as classes altas se sentiram especialmente afetadas, procurando tomar medidas para proteger seus interesses.

Um fator político atinente à luta de classes também teve seu peso para suscitar reações da burguesia. O aumento do desemprego e a alta da inflação gerados pela crise fizeram crescer o descontentamento geral dos trabalhadores. Segundo avaliação de Harvey, parecia se esboçar em muitos países uma alternativa à esquerda, de caráter socialista, a partir da conjunção dos movimentos sociais que se seguiram à crise.

Assim, foram necessárias condições político-econômicas específicas para que as idéias surgidas nos anos 1940 ganhassem respaldo e guiassem um processo de transformação do capitalismo. Contudo, Harvey apresenta duas alternativas interpretativas do que teria sido o neoliberalismo, das quais, seguindo as indicações de Duménil e Lévy, elege uma:

Podemos, portanto, interpretar a neoliberalização seja como um projeto utópico de realizar um plano teórico de reorganização do capitalismo internacional ou como um projeto político de restabelecimento das condições da acumulação do capital e

\footnotetext{
${ }^{344}$ Harvey apresenta dados mostrando que, nos Estados Unidos, a parcela da renda nacional concentrada nas mãos do $1 \%$ mais rico caiu de $16 \%$ antes da Segunda Guerra para $8 \%$ depois dela, permanecendo perto desse patamar durante três décadas - Cf. HARVEY, O neoliberalismo, p. 25.
} 
de restauração do poder das elites econômicas. Defenderei a seguir a idéia de que o segundo desses objetivos na prática predominou. ${ }^{345}$

Embora focalizando os processos específicos que instauraram o poder da finança, Chesnais interpreta o neoliberalismo da mesma forma, partilhando explicitamente da visão de Duménil e Lévy: "o objetivo do neoliberalismo (...) era recolocar o poder e a riqueza tão plenamente quanto possível nas mãos da fração superior das classes capitalistas e das instituições onde se concentra sua capacidade de ação",346 . E também como Harvey, Chesnais defende que os progressos da era neoliberal em termos de retomada do crescimento econômico foram decepcionantes, ao passo que o movimento de concentração de poder e riqueza nas frações superiores da burguesia foi de grande êxito ${ }^{347}$.

Ademais, argumenta Harvey, quando os princípios da teoria neoliberal conflitam com esse objetivo político, acabam na prática sendo abandonados ou distorcidos, como é o caso de inúmeros países da América Latina em que o neoliberalismo foi implementado através de golpes de Estados e governos ditatoriais e intervencionistas ${ }^{348}$.

A descrição geral do neoliberalismo feita por Harvey contém muitos dos aspectos já apontados por Chesnais em sua descrição do processo de instauração do poder da finança, inclusive na determinação dos protagonistas. Em primeiro lugar, o neoliberalismo envolveu profundas mudanças nas políticas econômica, fiscal e social dos Estados, incluindo a flexibilidade do câmbio, cortes de gastos (principalmente na área social), redução de impostos sobre o capital e grandes riquezas e a elevação da taxa de juros. Essas mudanças foram usadas para quebrar o poder sindical e das organizações de trabalhadores, ao gerarem desemprego e revogarem proteções sociais, por exemplo ${ }^{349}$. Além disso, houve igualmente mudanças de caráter mais institucional, como as privatizações e as liberalizações/desregulamentações de

\footnotetext{
${ }^{345}$ HARVEY, O neoliberalismo, p. 27.

${ }^{346}$ CHESNAIS, “O capital portador de juros (...)”, pp. 56-57.

${ }^{347}$ Ver, por exemplo, dados em HARVEY, op. cit., p. 26.

${ }^{348}$ A implementação do neoliberalismo teria se processado amplamente através do "uso da força", quer militar, quer financeira - Cf. Ibidem, p. 50.

349 "O enfraquecimento (...), a superação (...) ou a destruição violenta (...) das forças do trabalho organizado é uma precondição necessária da neoliberalização” - Ibidem, p. 126.
} 
mercados, inclusive financeiros, dos fluxos de capital com o exterior, das relações trabalhistas, etc.

Se, para Chesnais, o neoliberalismo coincide de modo geral com a história da imposição da dominação da finança, na análise de Harvey ela também é central, mas insere-se em um processo mais amplo de transformações. O poder do capital financeiro aparece mais claramente como produzindo o neoliberalismo e sendo por ele fortalecido. A desregulamentação financeira, por exemplo, pode ser vista como o resultado das pressões dos atores diretamente ligados ao capital portador de juros sobre os governos, como também uma medida tomada por estes na tentativa de aliviar os efeitos negativos da crise de sobreacumulação, que acabaram por reforçar a posição daqueles. De todo modo, para ambos os autores a desregulamentação da atividade financeira e dos fluxos de capital foi crucial no processo de neoliberalização. Ela tanto abriu novas oportunidades de valorização para o capital financeiro, como permitiu a arbitragem com as vantagens locais de cada região ou país do globo.

Harvey também enfatiza o papel da crise do petróleo no processo, como fator impulsionador do neoliberalismo, sobretudo nos países emergentes. Ao resultar no enriquecimento dos países produtores, ela criou uma massa de dólares em busca de valorização, cujos alvos mais atraentes eram os governos, principalmente dos países emergentes. As condições favoráveis levaram muitos desses países a tomarem empréstimos, o que deu vazão ao capital monetário excedente daqueles e se mostrou uma armadilha eficaz, na medida em que a dívida externa foi posteriormente usada para obrigar muitos países a se adequarem ao modelo neoliberal ${ }^{350}$.

Os fundos excedentes de capital, advindos não só da crise do petróleo, também foram reciclados pelos bancos de investimento de Nova York (novos atores do regime financeirizado apontados por Chesnais). Isso, segundo Harvey, gerou uma mudança importante: se até 1973 a maioria dos investimentos externos dos EUA era de tipo direto, depois dessa data os investimentos desses bancos se acentuam, o que exigiu a liberalização do crédito e dos mercados financeiros internacionais. O governo dos EUA passou, assim, a apoiar e a estimular esse processo em todo o mundo, abrindo caminho para os investimentos financeiros especulativos. Logo, "a restauração do poder a uma elite econômica ou classe alta

\footnotetext{
${ }^{350}$ Por exemplo, o México. Sua dívida externa passou de 6,8 bilhões em 1972 para 58 bilhões de dólares em 1982. Além disso, foi para o México, em 1984, o primeiro empréstimo do Banco Mundial a um país em troca de reformas estruturais neoliberais- Cf. HARVEY, O neoliberalismo, p. 108-109.
} 
nos Estados Unidos e em outros países capitalistas avançados apoiou-se pesadamente em mais-valia extraída do resto do mundo por meio de fluxos internacionais e práticas de ajuste estrutural" ${ }^{\prime 351}$.

Porém, se o neoliberalismo é definido como um processo de restauração do poder da classe alta, a centralidade da finança deve-se fazer notar não somente pelo aumento das atividades financeiras e pelas mudanças institucionais provocadas - amplamente descritos por Chesnais - mas também pela sua capacidade de implementar essa restauração e de reconfigurar o que seja essa classe alta. Harvey confessa a dificuldade de definir exatamente o que é "classe" 352 quando esta "não é uma configuração social estável", mas, de todo modo, assinala que "o neoliberalismo não significou necessariamente a restauração do poder econômico às mesmas pessoas" $" 353$.

Ainda assim, embora a composição social da "classe alta" possa variar muito de país para país, Harvey destaca tendências comuns no processo de neoliberalização que coincidem com os apontamentos de Chesnais. A primeira delas é que a tradicional separação, nas sociedades anônimas, entre a propriedade do capital e as atividades de gerência se enfraquece quando se passa a remunerar os administradores com stock options, cujo resultado é que "o valor das ações tomou o lugar da produção como guia da atividade econômica"354. Viu-se que isso está vinculado à governança corporativa das empresas, uma visão de gestão que surge e se difunde na era neoliberal.

O movimento ocorrido é interessante de se observar. Antes, a figura do capitalista reunia as duas dimensões, propriedade e gerência. Com o advento das sociedades anônimas, operou-se a separação e mesmo a oposição entre ambas, ao se criar a distinção entre administrador e acionistas. Contudo, principalmente durante o período fordista, o administrador detinha poder considerável em torno de si, como agente responsável pela produção. Por fim, o neoliberalismo opera uma espécie de "síntese", na medida em que, de certa forma, reúne novamente a propriedade e a gerência, porém sob a égide da propriedade, do acionista, do capital portador de juros - gerando todas as conseqüências sociais apontadas.

\footnotetext{
${ }^{351}$ HARVEY, O neoliberalismo, p. 38.

${ }^{352}$ Aqui reaparece a mesma dificuldade apontada no final do Capítulo 1 sobre como analisar as frações da burguesia (pertinência ou não da distinção entre burguesia industrial e burguesia financeira, por exemplo).

${ }^{353}$ Ibidem, p. 40.

${ }^{354}$ Ibidem, p. 41.
} 
A segunda tendência mencionada por Harvey é a drástica redução da separação entre capital monetário (em busca de juros e dividendos) e capital aplicado na produção (voltado para a obtenção de lucros). O resultado é que as grandes empresas assumiram um viés crescentemente financeiro, mesmo quando mantinham atividades produtivas (tornando-se o que Chesnais chama de "grupos financeiros de predominância industrial"). Além disso, as fusões de empresas de diferentes ramos produziram conglomerados em que os interesses financeiros e produtivos se interpenetraram de novas maneiras ${ }^{355}$. Isso tudo vem acompanhado da face mais visível da financeirização, que é a forte expansão das atividades, produtos e mercados financeiros, abrindo oportunidades cada vez mais diversificadas para as aplicações financeiras.

Essas duas tendências estão estreitamente vinculadas entre si - sendo manifestações em planos diferentes de um mesmo movimento - e representam um dos pilares da "dominância financeira" de Chesnais: o alojamento da "exterioridade da finança" no seio da produção. Assim, o mesmo processo que institui a virada financeira - entendida como uma mudança no padrão de acumulação do capital - é parte do movimento neoliberal de minar o poder do trabalho e de reconfigurar as relações de poder no interior da burguesia ${ }^{356}$. Como resume Harvey: “A neoliberalização significou a 'financialização' de tudo. Isso aprofundou o domínio das finanças sobre todas as outras áreas da economia, assim como sobre o aparato de Estado e (...) a vida cotidiana. (...) [Houve] uma mudança de poder da produção para o mundo das finanças",357.

O fato de que, segundo Harvey, a reorientação do poder em prol da finança resultou em uma dissociação que favoreceu Wall Street em detrimento do resto dos EUA e do mundo leva exatamente ao questionamento de se essa nova configuração de classe deve ser situada no âmbito do Estado-nação ou se teria caráter transnacional. $\mathrm{O}$ autor pondera que a lealdade da classe dominante a algum Estado-nação foi habitualmente exagerada, pois sempre houve conexões entre capitalistas de diversos países. Além disso:

\footnotetext{
Não há, contudo, dúvidas de que houve uma ampliação dessas ligações transnacionais durante a fase de globalização neoliberal (...). Mas isso não significa que as principais figuras dessa classe não estejam associadas a aparatos de Estado
}

\footnotetext{
${ }^{355}$ É o caso das holdings, em que um centro financeiro coordena diversos setores produtivos, arbitrando entre a rentabilidade de cada um.

356 “Assim, um dos núcleos substanciais da ascensão do poder de classe sob o neoliberalismo reside nos CEOs, os principais operadores dos conselhos de administração, e nos líderes dos aparatos financeiros, legais e técnicos que cercam a quintessência da atividade capitalista” - HARVEY, O neoliberalismo, p. 42.

${ }^{357}$ Ibidem, pp. 41-42.
} 
específicos, devido tanto às vantagens como às proteções que isso lhes proporciona. $^{358}$

Nesse sentido, os interesses capitalistas são eminentemente transnacionais e a neoliberalização auxiliou na efetivação dos mesmos. Contudo, a classe dominante também se aproveita da lógica geopolítica do Estado para obter vantagens específicas ligadas ao pertencimento a determinado território - e às vezes a mais do que um. Dessa forma, o Estado desempenha um papel importante na promoção dos interesses capitalistas a ele ligados, sobretudo em sua forma neoliberal.

O papel do Estado na teoria neoliberal, segundo Harvey, não é difícil de definir. De modo geral, ele deve promover e garantir os "direitos individuais da propriedade privada, o regime de direito e as instituições de mercados de livre funcionamento e do livre comércio" ${ }^{359}$. Os contratos e os direitos individuais (de ação, de expressão e de escolha) devem, pois, ser preservados, assim como, por extensão, a liberdade de negócio e das corporações (que, como é ressaltado, são legalmente "indivíduos"). Adicionalmente, protegem-se especificamente os direitos de propriedade intelectual, considerados fundamentais para um dos pilares do progresso social e econômico - o desenvolvimento tecnológico ${ }^{360}$.

A crença nas virtudes do mercado conduz igualmente a uma preferência pela privatização de ativos e pela liberalização dos fluxos de capital ${ }^{361}$. Direitos claros de propriedade e a competição no mercado seriam os melhores caminhos para a eficiência, a produtividade e a igualdade de condições. Do mesmo modo, presume-se que os indivíduos sejam responsáveis por suas próprias ações e bem-estar (incluindo saúde, educação e aposentadoria) $)^{362}$, assim como por seus fracassos ou sucessos pessoais ${ }^{363}$.

\footnotetext{
${ }^{358}$ HARVEY, O neoliberalismo, p. 44.

${ }^{359}$ Ibidem, p. 75.

360 Chesnais e Bihr identificam, como se viu no Capítulo 3, o desenvolvimento do neoliberalismo e da financeirização com a extensão do domínio da propriedade privada.

${ }^{361}$ Quanto à mobilidade da força de trabalho, isso já não é tão certo.

${ }^{362}$ Marx apresenta, de forma irônica, as duas faces da liberdade do trabalhador: ele é livre no sentido de ser dono da própria força de trabalho, e é "livre" para escolher para quem vendê-la. Analogamente, isso pode ser aplicado
} 
Mesmo no plano da teoria, contudo, Harvey já identifica tensões ou contradições no Estado neoliberal. Em primeiro lugar, há a questão de como tratar os monopólios, que resultam da própria dinâmica da concorrência de mercado. A princípio não caberia intervir, mas a monopolização excessiva gera lucros abusivos e outras irregularidades. Em segundo lugar, há o problema dos "fracassos de mercado" ou das "externalidades negativas", ou seja, como regular ou não, por exemplo, a poluição ou a degradação do meio ambiente decorrentes das atividades econômicas. Por fim, há também a relação complexa com a democracia. Segundo Harvey,

Para defender-se de seus maiores temores - o fascismo, o comunismo, o socialismo, o populismo e mesmo o regime da maioria -, os neoliberais têm de impor fortes limites à governança democrática, apoiando-se em vez disso em instituições não-democráticas e que não prestam contas a ninguém (como o Banco Central norte-americano e o FMI [note-se que ambos os exemplos são instituições ligadas à finança - I.L.]) (...) Diante de movimentos sociais que buscam intervenções coletivas, o Estado neoliberal é forçado, por conseguinte, a intervir, por vezes repressivamente, negando assim as próprias liberdades de que se supõe ser o garante. ${ }^{364}$

É de se supor, portanto, que a atuação do Estado neoliberal na prática seja ainda mais complicada, desviando-se, às vezes muito, do que prega a teoria, e apresentando diversas variantes. Na concepção de Harvey, o "Estado neoliberal" na realidade corresponde a:

Um tipo peculiar de aparelho de Estado cuja missão fundamental foi criar condições favoráveis à acumulação lucrativa de capital pelos capitalistas domésticos e estrangeiros (...). As liberdades que encarna refletem os interesses dos detentores de propriedade privada, dos negócios, das corporações multinacionais e do capital financeiro. ${ }^{365}$

Ele pode, pois, ser contraposto a um "Estado intervencionista", que vigia durante o fordismo-keynesianismo, quando "o Estado transformou-se na verdade num campo de força que internalizou relações de classe. Instituições da classe trabalhadora como sindicatos e

aqui: o indivíduo é livre para escolher o que é melhor para si, assim como é "livre" para optar por um serviço ruim ou por nem mesmo ter acesso a ele.

${ }^{363}$ Harvey observa que a proliferação das ONGs durante o neoliberalismo não é casual. Apesar das diferenças existentes, de modo geral elas corresponderiam à necessidade de preencher esse vazio de benefícios sociais, de auxiliar os "fracassados" ou "perdedores". Mais do que isso, em alguns casos elas acabariam justificando que o Estado se desincumbisse desses benefícios, de modo que, para o autor, as ONGs funcionaram como uma espécie de "cavalo de Tróia" do neoliberalismo - Cf. HARVEY, O neoliberalismo, p. 190.

364 Ibidem, p. 80.

365 Ibidem, p. 17. 
partidos políticos de esquerda tiveram uma influência bastante concreta no aparato de Estado" ${ }^{, 366}$.

Harvey menciona dois âmbitos em particular nos quais o Estado neoliberal distorce ou abandona seus princípios teóricos. O primeiro seria o de "problemas friccionais" "367 da transição para o próprio neoliberalismo. Dependendo da forma de Estado que precede a virada neoliberal, é mais ou menos necessário o uso, por parte do Estado, da coerção, da intervenção em determinados setores, das privatizações, etc. O segundo campo seria o da sua função de criar um clima propício aos negócios e investimentos capitalistas - sobretudo em um contexto de ampla liberalização, em que a concorrência é cada vez mais mundializada. $\mathrm{O}$ tratamento do trabalho e do ambiente como mercadorias permitiria dar prioridade ao "clima de negócios" em detrimento dos direitos dos trabalhadores e da preservação do ambiente. Ademais, e em estreita correlação com isso, está o favorecimento, em caso de conflito, do sistema financeiro e da solvência de suas instituições em prejuízo novamente da população e do ambiente.

Nesse sentido, diz Harvey, "talvez as práticas contemporâneas relativas ao capital financeiro e às instituições financeiras sejam as mais difíceis de conciliar com a ortodoxia neoliberal” ${ }^{\text {368 }}$. Nos momentos de crise, principalmente, é impressionante o montante de auxílios que Estados neoliberais dispensam para evitar a insolvência de instituições financeiras privadas. Da mesma forma, no plano internacional, FMI e Banco Mundial recebem autoridade para renegociar dívidas e, assim, evitar a falência das instituições financeiras internacionais ${ }^{369}$. A contradição, portanto é evidente. A financeirização, um dos pilares da implementação do neoliberalismo e que se tornou realidade exatamente através de desregulamentações e liberalizações, acaba por ser fonte de um dos principais pontos de inadequação entre teoria e prática neoliberais. Tal contradição reforça o ponto de vista de que o neoliberalismo é antes um projeto de restauração de poder das classes altas do que um projeto teórico para reorganizar o capitalismo e promover em si o crescimento.

Há ainda as conseqüências práticas dos processos de financeirização a esse respeito. Todas essas proteções e auxílios ao capital financeiro consistem em garantir a obtenção de "mais-valia de populações empobrecidas do Terceiro Mundo para pagar aos banqueiros internacionais (...). A extração de tributos via mecanismos financeiros é uma velha prática

\footnotetext{
${ }^{366}$ HARVEY, O neoliberalismo, p. 21.

${ }^{367}$ Ibidem, p. 81.

${ }^{368}$ Ibidem, p. 83.

${ }^{369}$ Devido a tamanha contradição, Harvey salienta que teóricos neoliberais mais radicais são a favor da abolição do FMI - Cf. Ibidem, p. 83.
} 
imperial" ${ }^{370}$. Esta se constitui numa estratégia muito eficaz para o objetivo neoliberal de restauração do poder de classe, mas se baseia em assimetria de condições e em pressões extraeconômicas que não se encaixam bem na teoria.

Segundo Harvey, o Estado neoliberal possui ainda outros elementos que permitem entrever a que tipo de "regulação" dá origem. Ele é hostil a qualquer forma de solidariedade social que estabeleça restrições à acumulação do capital. A transição para a acumulação "flexível" teve exatamente o efeito de quebrar o vínculo entre os trabalhadores, assim como de enfraquecer os contratos de trabalho. Além disso, devido à sua dificuldade de lidar com a democracia, o Estado neoliberal precisou encontrar formas de integrar suas ações às exigências da acumulação do capital e ao poder de classe em restauração/formação. Um grande exemplo são as parcerias público-privadas, que abrem mais espaço para que os interesses privados se entrelacem com as decisões governamentais. A influência das corporações sobre a legislação aumenta e as atitudes coercitivas por parte do Estado neoliberal também são ampliadas, de modo que os mecanismos de vigilância e policiamento se multiplicam. Em suma, isso "nos permite ver com clareza que o neoliberalismo (...) não torna irrelevante o Estado nem instituições particulares do Estado (...). Tem havido no entanto uma radical reconfiguração das instituições e práticas do Estado",371.

Tais práticas são contraditórias ${ }^{372}$, o que fragiliza de alguma forma sua legitimação. Embora o neoliberalismo seja um conjunto amplo de transformações que parece ter se consolidado, Harvey admite que o Estado neoliberal possa ser uma forma política transitória ou instável. Para ele há indícios de que nos EUA esteja se delineando uma resposta "neoconservadora" para a questão. Não se trata de um abandono do neoliberalismo em geral; ao contrário, o neoconservadorismo se coaduna bem com o projeto de restauração do poder de classe da elite, com a desconfiança em relação à democracia e com as liberdades de mercado. Ele se afasta, todavia, do neoliberalismo puro em dois aspectos: na preocupação com a manutenção da ordem como contraponto ao caos dos interesses individuais e no recurso a uma moral inflexível ${ }^{373}$ - baseada sobretudo em valores cristãos e nacionalistas - como

\footnotetext{
${ }^{370}$ HARVEY, $O$ neoliberalismo, p. 84.

${ }^{371}$ Ibidem, pp. 88-89.

372 Harvey apresenta uma série de 5 "contradições mais específicas": Intervenção e não-intervenção; autoritarismo e liberdade; preservação do sistema financeiro e desestímulo ao "individualismo irresponsável"; competição e oligopolização; liberdade de mercado e preservação da coesão social - Cf. Ibidem, pp. 89-91.

373 Harvey ainda aponta que, diante da tendência do neoliberalismo à mercantilização de tudo, uma das distinções entre neoliberalismo e neoconservadorismo residiria em onde traçar os limites a esse processo. Os
} 
“cimento social". Consequentemente, o neoconservadorismo desvela o autoritarismo oculto no neoliberalismo, justificando maior grau de coerção tanto interna como externa, em busca de maior consentimento por meio dos valores morais que invoca.

Por mais que o neoconservadorismo represente mudanças políticas importantes, não rompe com o objetivo geral do neoliberalismo, nem com seus meios de atuação. Nesse sentido, ele pode ser uma forma de resposta a certas dificuldades do Estado neoliberal, sem alterar o rumo que o neoliberalismo tomou, incluindo o papel preponderante da financeirização.

Nesse sentido, as considerações de Harvey sobre a China são particularmente interessantes. Primeiramente, para tratar da questão - decorrente das contradições presentes no próprio Estado neoliberal e das diferentes formas que ele pode assumir - de quais critérios seriam fundamentais para caracterizar um Estado como neoliberal. Ou melhor, de como reconhecer a presença do neoliberalismo em um país, apesar dos "desvios" de seu Estado em relação aos preceitos da teoria. Em segundo lugar, o caso da China mostra que a tendência ao neoconservadorismo não é exclusiva dos EUA, podendo percorrer um trajeto bastante distinto. A caracterização pelo autor de um "neoliberalismo "com características chinesas",374 mostra, de fato, que o elemento central na definição do neoliberalismo não é qualquer princípio teórico em especial, mas determinado movimento de restauração (ou de instauração, como foi o caso da China) do poder da classe dominante.

Conforme a interpretação de Harvey, as reformas empreendidas por Deng Xiaoping em 1978 resultaram em um "tipo específico de economia de mercado que incorporou crescentemente elementos neoliberais entrelaçados com o controle centralizado autoritário", compatibilizando, portanto, enormes desvios dos princípios, sobretudo políticos, do neoliberalismo com uma série de aspectos do modus operandi deste. Assim, a abertura da economia ao mercado e aos investimentos externos, as privatizações, as mudanças na política monetária, entre outros fatores ${ }^{375}$, se coadunaram com elementos tais como a repressão

neoconservadores seriam mais restritivos, como, por exemplo, em relação ao casamento e outras questões morais.

${ }^{374}$ HARVEY, $O$ neoliberalismo, cap. 5.

${ }^{375}$ Harvey não destaca, no caso da China, o papel do sistema financeiro. Ao contrário, o sistema bancário chinês é estatal e as finanças ainda não foram "devidamente" liberalizadas, o que limita "o poder do capital financeiro internacional sobre o Estado chinês (...) e priva o capital de uma de suas principais armas com relação ao poder do Estado" - HARVEY, O neoliberalismo, p. 134. A maior especulação com ativos ocorre no setor imobiliário (Cf. Ibidem, p. 159). Contudo, não se pode desprezar a importância da liberalização financeira no resto do mundo, o que provavelmente facilitou os investimentos diretos na China, bem como permitiu que esta investisse grandes somas no exterior (capital excedente), em títulos americanos principalmente. 
violenta da força de trabalho chinesa, desconsideração pelos direitos individuais, e um Estado intervencionista na vida social e na dinâmica econômica.

Independentemente, contudo, de como esses elementos se combinam, o que se nota na China desde o início das reformas foi a criação de um enorme proletariado, de um lado, e de uma classe capitalista cada vez mais rica e poderosa, de outro, instaurando, assim, as condições para a acumulação capitalista. A desigualdade de renda atingiu níveis sem precedentes, serviços sociais foram reduzidos pelo Estado, a especulação imobiliária e a grilagem de terras expulsaram camponeses de suas terras e as centralizaram nas mãos de poucos, as relações de trabalho em vigor permitiram uma superexploração da força de trabalho e a supressão de empregos, etc. ${ }^{376}$.

Desse modo, mesmo sem ter ainda consolidado o capitalismo no seu território e violando muitos aspectos da teoria neoliberal, a China parece se enquadrar como uma economia neoliberal de características próprias. Ao mesmo tempo, suas práticas políticas indicam uma aproximação com o neoconservadorismo:

\footnotetext{
Podemos concluir que a China tomou inequivocamente o rumo da neoliberalização e da restauração do poder de classe, ainda que 'com características peculiarmente chinesas'. Contudo, o autoritarismo, o apelo ao nacionalismo e a retomada de certas pressões de cunho imperialista sugerem que a China pode estar caminhando (...) para uma confluência com a maré neoconservadora". 377
}

Ao se levar em conta que a virada para a financeirização e a articulação de um “complexo Wall Street-FMI-Tesouro dos Estados Unidos"378 são duas peças-chave para o cumprimento dos objetivos do neoliberalismo e que uma de suas consequências nefastas é o impressionante fluxo de "tributos" rumo aos principais centros financeiros mundiais, constatase que muitos elementos importantes da "realidade" neoliberal são escamoteados pela teoria. Esta busca suavizá-los, naturalizá-los ou mesmo inverter seu sentido por meio de um vocabulário carregado ideologicamente de expressões como "liberdade" e "direitos",379.

\footnotetext{
${ }^{376}$ Cf. HARVEY, O neoliberalismo, p. 154 e seguintes.

${ }^{377}$ Ibidem, p. 163.

${ }^{378}$ Expressão emprestada de Peter Gowan. Cf. Ibidem, p. 102.

${ }^{379}$ Cf. Ibidem, pp. 128-129.
} 
Tenta-se até mesmo desvincular as crises financeiras, que se tornaram muito contagiosas e recorrentes, dos resultados do neoliberalismo, imputando-as, ao contrário, a desvios de suas prescrições.

Da mesma forma, outra característica do neoliberalismo é um tipo muito peculiar de fetichismo, de ocultamento dos processos sociais. As privatizações, por exemplo, ao transferirem ativos do domínio público para o privado, apagam toda a trajetória de construção daquele patrimônio coletivo - quem o financiou, sob quais condições (políticas, sociais), etc. - e os transformam numa mercadoria, sem passado e sob controle privado. A Coréia do Sul fornece um exemplo bastante ilustrativo ${ }^{380}$ : os chaebols, grandes complexos industriais de caráter monopolista constituídos a partir das políticas de incentivo do Estado desenvolvimentista, ao se consolidarem mundialmente e passarem a prescindir dessa intervenção estatal, voltam-se contra esse próprio Estado e pressionam pela liberalização e desregulamentação. Todo o investimento coletivo e público nos chaebols então se coloca - na condição de interesses inteiramente privados - contra o Estado e contra os trabalhadores, em prol do aprimoramento das condições da acumulação capitalista no país.

O que essas e outras estratégias do neoliberalismo possuem em comum é, portanto, seu caráter "espoliativo". A "acumulação por espoliação", conceito cunhado por Harvey a partir de observações de Rosa Luxemburgo e da "acumulação primitiva" de Marx, se distingue dos processos "moleculares" de acumulação de capital (ou seja, de produção de mercadorias com extração de mais-valia). Ela envolve toda a gama de processos "extra"econômicos de apropriação de riqueza, paralelos à produção, porém igualmente imprescindíveis para a reprodução do capitalismo (principalmente em situações de sobreacumulação do capital). Trata-se, pois, do recurso a mecanismos coercitivos ou violentos de apropriação direta de recursos ou de instauração de condições (iniciais ou aperfeiçoadas) para a reprodução ampliada de capital.

O neoliberalismo se constituiu, assim, como um contexto favorável para a expansão e aprofundamento dos mecanismos de acumulação por espoliação, ainda que por meio de um processo bastante contraditório.

A acumulação por espoliação ganha centralidade no capitalismo como instrumento para responder, sobretudo, a dois elementos: a tentativa dos países centrais de resolver a crise de sobreacumulação dos anos 1970 evitando desvalorizações e reformas internas; e a meta das

\footnotetext{
${ }^{380}$ Comentado em HARVEY, O neoliberalismo, pp. 116 e seguintes.
} 
classes altas de restauração de seu poder. Contudo, ela não foi bem sucedida em ambos - e talvez nem pudesse. Por seus métodos de coerção e violência direta, conseguiu quebrar o poder e a organização da classe trabalhadora com grande eficácia em muitos países. Por outro lado, o neoliberalismo fracassou em restabelecer o crescimento econômico ${ }^{381}$. A acumulação por espoliação pode centralizar rapidamente o capital e abrir oportunidades vantajosas para novos investimentos, contudo não substitui a reprodução ampliada na geração de valor novo e na expansão do capitalismo.

Pode-se então formular a hipótese de que o comprometimento profundo do neoliberalismo com a acumulação por espoliação e sua dependência desta enfraqueceu o impulso à expansão da reprodução ampliada ${ }^{382}$. Talvez seja isso que Harvey tenha em mente quando aponta uma "tensão entre, de um lado, a sustentação do capitalismo e, de outro, a restauração/reconstituição do poder de classe" ${ }^{\text {383 }}$.

Tal hipótese condiz com a caracterização que Chesnais faz do regime financeirizado. A ascensão do poder (econômico e de classe) da finança marca a era de "atonia" da produção, com relativo baixo crescimento na maioria dos países centrais, e de instabilidades e crises financeiras crônicas. A causa estaria principalmente nas "punções" sobre a produção (juros, dividendos), que reduzem os investimentos produtivos, e nas diversas oportunidades abertas para a "valorização financeira", que estimulam os capitalistas individuais a recorrer a esses processos fictícios em detrimento dos circuitos produtivos.

Essa valorização fictícia, fundada na especulação e em muitos aspectos vinculada a processos espoliativos não geram valor em termos sociais. O que ajuda a compreender por que o neoliberalismo não obteve o sucesso pretendido em retomar a expansão da acumulação "produtiva" é, contraditoriamente, exatamente o fato de a financeirização ser um componente central da acumulação por espoliação atualmente ${ }^{384}$.

Essa relação fica evidente na enumeração que Harvey faz dos mecanismos da acumulação por espoliação. Constam, por exemplo: a monetização do câmbio e a taxação, a usura, a dívida nacional e o uso do sistema de crédito $^{385}$. Além disso, o autor define quatro

\footnotetext{
${ }^{381}$ Chesnais e Harvey estão de acordo sobre isso. Comparar: CHESNAIS, "O capital portador de juros(...)", pp. 56-57 e HARVEY, O neoliberalismo, p. 27.

382 Como contribuição a essa hipótese pode-se invocar a seguinte passagem: "A principal realização substantiva da neoliberalização foi (...) redistribuir, em vez de criar, riqueza e renda" - HARVEY, O neoliberalismo, p. 171.

${ }^{383}$ Ibidem, p. 165.

${ }^{384}$ O que ocorre, como visto, é uma situação contraditória de baixa acumulação, mas alto nível de lucros.

${ }^{385}$ Cf. Ibidem, p. 172.
} 
características principais da acumulação por espoliação ${ }^{386}$ que não deixam dúvidas quanto à sua relação umbilical com a financeirização. Primeiramente, a privatização e mercantilização na maior extensão possível, com o objetivo de abrir novos campos para a acumulação do capital. Viu-se que o capital financeiro é o grande beneficiário dessas medidas. Em segundo lugar, há a própria "financeirização"387 [financialization], marcada pelo estilo especulativo e predatório do capital monetário a partir de 1980. A desregulação fez do sistema financeiro um dos principais centros de redistribuição de riqueza. Em terceiro lugar, figura a administração e manipulação de crises. Utilizam-se processos ligados ao capital financeiro, como as bolhas especulativas e a manipulação da dívida pública dos países, para realizar transferências de riqueza dos países pobres para os ricos. Por fim, há as próprias redistribuições via Estado, que, uma vez neoliberalizado e coagido pelo poder financeiro, passa a ser o principal agente de políticas de transferência de riqueza ${ }^{388}$.

Fica mais clara, desse modo, a relação estreita, ainda que contraditória, entre neoliberalismo, acumulação por espoliação e financeirização. Se Chesnais interpreta a história do neoliberalismo como o processo histórico e político de instauração da dominância financeira, Harvey inscreve a financeirização - concebida de modo mais estreito, é verdade nos elementos fundantes do neoliberalismo, compreendendo este como um movimento amplo de restauração do poder de classe da burguesia.

${ }^{386}$ Cf. HARVEY, O neoliberalismo, pp. 172-178.

${ }^{387}$ Harvey não precisa o significado do termo aqui, mas este parece ser usado em sentido mais restrito, como sinônimo da liberalização e desregulamentação dos fluxos financeiros e do aumento quantitativo das transações financeiras, sobretudo especulativas.

388 Devido à força de todos esses mecanismos em realocar a riqueza nas mãos dos mais ricos, Harvey conclui, como Chesnais, que "o advento da neoliberalização celebrou o papel do rentista" - Ibidem, p. 202. 


\section{CAPÍTULO 6 - FINANCEIRIZAÇÃO E IMPERIALISMO}

Em O novo imperialismo, Harvey desdobra sua análise do capitalismo contemporâneo sob um viés político, porém num plano diferente. Apresenta a questão da financeirização e da acumulação por espoliação sem focar diretamente as posições e lutas de classe no interior dos países, mas sim a relação entre os Estados. Seu objetivo é, a partir de uma perspectiva de mais longo prazo e do "materialismo histórico-geográfico", "examinar a atual condição do capitalismo global e o papel que um 'novo' imperialismo poderia estar desempenhando em seu âmbito" 389 .

Embora o autor não apresente de imediato uma definição desse novo imperialismo, este é caracterizado, de forma um tanto enigmática, como possuindo "qualidades novas, de cunho pós-moderno" ${ }^{\text {390 }}$, indicando que, de algum modo, ele estaria conectado com as mudanças mais amplas delineadas pela nova configuração do capitalismo (acumulação flexível e neoliberalismo). Esta, contudo, não é tratada sob a ótica regulacionista. Harvey demonstra ter se afastado da escola da regulação, não empregando mais seu vocabulário, nem fazendo mais referência a seus teóricos. Desse modo, tendo em vista o foco do livro, a periodização do capitalismo inicialmente destacada não se estrutura em termos de "regime de acumulação", mas adota como critério as mudanças das hegemonias no âmbito do sistema de nações.

O livro se concentra no papel do atual hegemon mundial capitalista, os EUA. Sua abertura discute um evento concreto recente: a Guerra do Iraque. Sem entrar em muitos detalhes, cabe observar que um dos fatores apontados como motivação da guerra é a tentativa de desviar a atenção dos problemas internos da sociedade estadunidense ${ }^{391}$ com os quais George W. Bush precisava lidar: recessão, desemprego, déficit público, etc. Harvey argumenta, contudo, que deve haver algo mais profundo do que esse oportunismo político. Para ele, o medo, sempre ampliado pela paranóia estadunidense, de um movimento pan-árabe e os problemas da democracia em uma sociedade tão individualista e competitiva, constituem

\footnotetext{
${ }^{389}$ HARVEY, O novo imperialismo, p. 11.

${ }^{390}$ Ibidem, p. 16.

${ }^{391}$ Esses problemas são apresentados como resultado da "dialética interna da sociedade civil norte-americana" Ibidem, p. 20. A idéia de dialética interna é retirada de Hegel, e Harvey trata dos fundamentos dessa questão - de forma abstrata, e não aplicada a algum país em especial - em outro lugar. Ver, HARVEY, "O ajuste espacial: Hegel, Von Thünen e Marx".
} 
fatores relevantes. "A sociedade como um todo parecia estar se fragmentando e perdendo a coesão com alarmante rapidez" ${ }^{, 392}$, enquanto o Estado parecia acumular mais poder. A conclusão é que: "o envolvimento com o Iraque foi bem mais do que mera manobra diversionista das dificuldades domésticas - foi uma grande oportunidade de impor um novo sentido de ordem social em casa e de submeter a comunidade" ${ }^{\text {,393. }}$.

Além disso, um dos fatores que conduzia a esse movimento imperialista foi a questão do controle sobre o petróleo. Harvey descarta o simplismo da teoria da conspiração - de que o interesse puro das companhias de petróleo, dominando o Estado, teve força suficiente para levar o país à guerra - e propõe uma explicação mais abrangente: controlando o Oriente Médio, os EUA dominariam o petróleo - um elemento estratégico de primeira ordem cada vez mais escasso (sobretudo a partir de 1980) -, e, por meio dele, a economia mundial. A guerra para ocupar o Iraque corresponderia, pois, a um interesse estratégico vital do Estado norteamericano como um todo.

A análise desse evento auxilia a compreensão do que seria, para Harvey, um "imperialismo capitalista":

\footnotetext{
Uma fusão contraditória entre 'a política do Estado e do império' (o imperialismo como projeto distintivamente político da parte dos atores cujo poder se baseia no domínio de um território e numa capacidade de mobilizar os recursos naturais e humanos para fins políticos, econômicos e militares) e 'os processos moleculares de acumulação do capital no espaço e no tempo' (o imperialismo como processo político-econômico difuso no espaço e no tempo no qual o domínio e o uso do capital assumem a primazia). ${ }^{394}$
}

Se, no primeiro aspecto, enfatizam-se as estratégias políticas, diplomáticas e militares invocadas pelo Estado para atingir seus objetivos, no segundo trata-se dos modos pelos quais o poder econômico percorre os espaços em direção ou em sentido contrário a entidades territoriais mediante as práticas cotidianas da produção, da troca, dos fluxos de capital, etc.

Nessa definição de imperialismo, está presente a idéia de que há simultaneamente em operação duas lógicas do poder, a "territorial" e a "capitalista",395, ainda que a última

\footnotetext{
${ }^{392}$ HARVEY, O novo imperialismo, p. 23.

${ }^{393}$ Ibidem, p. 24.

${ }^{394}$ Ibidem, p. 31.

${ }^{395}$ Nesse ponto Harvey recupera a teoria de Giovanni Arrighi. Ver ARRIGHI, O longo século XX.
} 
predomine na modalidade capitalista de imperialismo ${ }^{396}$. Essas duas lógicas, contudo, nem sempre coincidiriam. Ao contrário, normalmente estabelecem uma relação contraditória entre si. A lógica territorial seria aquela que motiva os políticos e homens de Estado, que procuram melhorar a posição e ampliar os poderes do território ao qual estão ligados e obter vantagens coletivas, por meio da acumulação do capital (e não tendo esta como fim). Por outro lado, a lógica capitalista seria aquela que leva à busca de lucros onde quer que suas possibilidades de obtenção sejam maiores, considerando-a como um fim em si. Exploram-se as desigualdades geográficas e eventualmente expande-se o território como meio para alcançar esse objetivo. As vantagens almejadas seriam de caráter individual e não se ligariam inextricavelmente a um território específico.

Contudo, essa divisão entre lógica territorial e lógica capitalista parece permeada de incoerências. O que levaria os Estados a agirem com uma lógica não-capitalista dentro do capitalismo? Robert Brenner ${ }^{397}$ apresenta uma crítica a essa distinção, indicando que só haveria uma lógica, a capitalista. A conquista e o domínio de territórios não seriam um fim em si dos Estados, mas estariam direta ou indiretamente ligados à promoção dos interesses capitalistas - que são dependentes da ação estatal. Ao perseguirem tais interesses, por outro lado, os políticos e estadistas estariam agindo em causa própria, já que a força do Estado também depende do desenvolvimento capitalista do país ${ }^{398}$. As contradições existentes entre a política externa do Estado e as necessidades do capital estariam ligadas, isso sim, à contradição entre a lógica do capital e o sistema multi-estatal, cujas origens situam-se no feudalismo ${ }^{399}$.

Seguindo Brenner, optou-se aqui por discernir entre "lógica estatal" e "lógica econômica", no seguinte sentido: a primeira se refere às ações e estratégias por parte do

\footnotetext{
396 "O que distingue o imperialismo capitalista de outras concepções de império é que nele predomina tipicamente a lógica capitalista, embora, como veremos, haja momentos em que a lógica territorial venha para o primeiro plano" - HARVEY, O novo imperialismo, p. 36.

397 BRENNER, "What is, and what is not, imperialism?".

398 Essa idéia, segundo Brenner, estaria contida na concepção de imperialismo efetivamente empregada por Harvey: "Como se nota, ao desenvolver sua interpretação efetiva do imperialismo capitalista - em contraste com o quadro conceitual geral no qual ele procura inseri-lo - Harvey apóia-se quase exclusivamente na concepção marxista padrão segundo a qual o Estado, tanto na política interna como na externa, é dependente do capital, porque os que governam (quem quer que eles sejam) tendem a achar que a realização dos seus próprios interesses (qualquer que eles sejam) depende da promoção dos lucros capitalistas e da acumulação de capital, pois estes são a condição sine qua non para o crescimento econômico e para a solvência financeira, e, portanto, para a estabilidade interna e para a força no exterior" - Ibidem, p. 83.

399 “Na minha opinião, a maneira de enfrentar essa questão não é fazendo referência a um conflito dúbio entre os interesses do capital e dos estados, mas, de modo mais simples e direto, ao caráter problemático da forma do Estado que historicamente surgiu para desempenhar as funções políticas exigidas para a reprodução do capital: o sistema de múltiplos estados" - Ibidem, p. 84.
} 
Estado em um sentido geopolítico, de buscar seus objetivos específicos como Estado, ao passo que a segunda remete às ações concernentes aos interesses imediatos da acumulação de capital. Ambas situam-se no âmbito geral do capitalismo e suas eventuais contradições são compreendidas também nesses termos, e não como a relação entre uma lógica capitalista e uma não-capitalista. Assim, no âmbito da "lógica estatal", o poder financeiro poderia ser usado como um instrumento propriamente político para obtenção de vantagens para um Estado específico. Por outro lado, na "lógica econômica", o poder financeiro opera segundo os interesses dos capitalistas e por meio dos processos regulares de acumulação de capital.

Nesse sentido, embora esteja claro que o poder financeiro se situa no âmbito dos processos econômicos, ao se concebê-lo em sentido amplo e considerando o que o próprio Harvey expõe, não parece descabido entendê-lo também como um instrumento político. Podese citar, por exemplo, a ação consciente de certos países centrais ou organismos internacionais sobre outros países - impondo ajustes estruturais, fidelidade política, ou determinadas formas de se proceder - a partir de constrangimentos concernentes à dívida externa destes últimos ou ameaçando cortar auxílios financeiros. Quanto aos EUA, a economia mais importante do globo e controladora do dinheiro mundial, ainda dispõem da vantagem de utilizar sua taxa de juros e o câmbio para alterar a macroeconomia mundial em seu benefício.

Em todo caso, qualquer que seja a lógica dominante, para Harvey a "hegemonia" se refere ao poder político exercido por meio da liderança e do consentimento, mas dificilmente isento de doses mais ou menos importantes de coerção. No caso do imperialismo, termo que o autor reserva para as relações de poder entre os Estados no sistema global de acumulação do capital, a hegemonia aplica-se, pois, ao âmbito dos Estados-nações. O período que vai de 1870 ao fim da Segunda Guerra, por exemplo, é definido como a ascensão dos imperialismos burgueses - a consolidação da hegemonia burguesa no mundo - capitaneada pela Inglaterra.

Em 1945, os EUA despontam como a potência dominante do mundo capitalista, liderando a produção, a tecnologia e o aparato militar. Desse momento até por volta de 1970 período que corresponde ao fordismo no registro de Condição pós-moderna - esteve em vigência a segunda etapa do regime político da burguesia, com a hegemonia estadunidense consolidada. Muitos dos aspectos já mencionados que caracterizam esse momento são retomados por Harvey: certa conciliação entre capital e trabalho, papel restrito e territorialmente confinado da especulação financeira, ajustes internos e ajustes espaçotemporais como estratégias para contornar a sobreacumulação, etc. 
Especificamente em relação aos EUA, eles teriam se apresentado, externamente, como os defensores da liberdade e da propriedade privada, protegendo as elites de outros países em troca de apoio político. Internamente, haveria dois princípios cardeais: manter a estabilidade e a ordem social e expandir continuamente a acumulação do capital e o consumo doméstico para garantir a prosperidade no país. Em suma, "o país se tornou o principal protagonista da projeção do poder burguês por todo o globo" 400 , ainda que seu imperialismo econômico fosse relativamente restrito. A acumulação do capital prosseguia principalmente por meio da reprodução ampliada.

Por volta dos anos 1970, as contradições se tornaram agudas. Desencadeou-se então um conflito pronunciado entre as lógicas "capitalista" e "territorial" (econômica e estatal) do $\operatorname{poder}^{401}$. A abrangência excessiva do império americano tornou sua hegemonia onerosa, conduzindo o país a uma crise fiscal. Buscando remediar essa situação, os EUA puseram em prática "o uso do direito de seigniorage e a impressão de mais dólares" "402. Isso pode ser interpretado como o uso do poder financeiro de um modo político por parte dos EUA.

Um dos resultados, por outro lado, foi o surgimento de pressões inflacionárias mundiais, com uma conseqüente explosão de capital fictício sem qualquer perspectiva de resgate. Segundo Harvey, a crise de sobreacumulação do capital sobreveio e com ela o final desse período de hegemonia: a competitividade do Japão e da Alemanha no setor manufatureiro abalava um dos pilares da hegemonia estadunidense e os excedentes de dólares contribuíram para o colapso do sistema criado em Bretton Woods.

Surge, então, um novo sistema, ainda sob tutela dos EUA, no qual se abandona o lastro ouro do dólar e liberalizam-se os fluxos de capital monetário - com Nova York alçada à posição de centro financeiro da economia global. A assim chamada "hegemonia neoliberal" (1970-2000), no contexto do imperialismo, representaria, portanto, no plano das relações de poder entre os Estados, o conjunto de transformações por que passou o capitalismo em virtude da crise de sobreacumulação do anos $70^{403}$. Como resume Harvey: “ameaçados no campo da produção, os Estados Unidos reagiram afirmando sua hegemonia por meio das finanças" ${ }^{\text {,04. }}$.

\footnotetext{
${ }^{400}$ HARVEY, O novo imperialismo, p. 53.

${ }^{401}$ Novamente a questão parece, na realidade, residir nas dificuldades que o capitalismo nos EUA encontrava na relação com o sistema de "múltiplos Estados".

402 Ibidem, p. 57.

${ }^{403}$ No capítulo anterior, analisou-se de forma mais ampla o que é o neoliberalismo e em que medida ele foi um projeto político que visou restaurar o poder da burguesia. No contexto do imperialismo, o "Estado neoliberal" figura como uma nova concepção da ação estatal que promove amplamente a acumulação por espoliação,
} 
Desse modo, é possível compreender a financeirização como mais do que um conjunto de respostas no plano econômico para os problemas colocados à acumulação do capital pela crise do fordismo. Ela se constitui igualmente em estratégias de caráter político para a manutenção do poder dos EUA (lógica estatal) ${ }^{405}$. Mas, como Chesnais também ressalta, o processo de liberalização em escala mundial foi lento, passou por etapas, e demandou grande pressão dos EUA - auxiliados por organismos internacionais e apoiados na doutrina neoliberal.

A descrição do processo de financeirização apresentada por Harvey é menos detalhada que a de Chesnais, mas apresenta muitos dos mesmos elementos: "a passagem do equilíbrio de poder e de interesses no seio da burguesia das atividades produtivas para as instituições de capital financeiro" ${ }^{406}$, o uso do poder financeiro para quebrar o poder da classe trabalhadora, vulnerabilidade do Estado frente à especulação (devido a seu endividamento crônico) e a crescente volatilidade internacional do capital financeiro.

À diferença de Chesnais, todavia, que inclui claramente as mudanças organizacionais e tecnológicas relativas à produção na esteira da financeirização (e mesmo como uma espécie de conseqüência desta ${ }^{407}$ ), Harvey novamente é ambíguo quanto à relação entre os movimentos: "toda essa mudança [que tornou o capital financeiro central] não teria tido o efeito que teve não fosse a ação de uma bateria de mudanças tecnológicas e organizacionais que permitiu que a manufatura se tornasse muito mais fluida e flexível" ${ }^{\text {408 }}$.

Se, para Chesnais, o movimento crucial é a ascensão do capital financeiro ao primeiro plano, Harvey oscila quanto a se haveria ou não uma "hierarquia" entre os dois processos, talvez por interpretá-los como decorrências gerais da crise de sobreacumulação do capital. Assim, a "acumulação flexível” se constitui em um conjunto de vários elementos que emergem dessa crise. Contudo, é fundamental lembrar que Harvey afirma, em Condição pósmoderna, que as mudanças organizacionais e tecnológicas se mostram mais como o resultado

\footnotetext{
sobretudo no exterior: "Era necessário, além da financialização e do comércio mais livre, uma abordagem radicalmente distinta da maneira como o poder do Estado, sempre um grande agente da acumulação por espoliação, devia se desenvolver. O surgimento da teoria neoliberal e a política de privatização a ela associada simbolizaram grande parcela do tom geral dessa transição" - HARVEY, O novo imperialismo, p. 129.

${ }^{404}$ Ibidem, p. 58.

${ }^{405}$ Embora essa sua dimensão nem sempre esteja tão clara aos agentes.

406 Ibidem, p. 59.

${ }^{407}$ Ver Parte I, em especial pp. 36-37 e 65.

${ }^{408}$ HARVEY, O novo imperialismo, p. 59.
} 
da busca de soluções financeiras do que o contrário ${ }^{409}$, concordando, em grande medida, com Chesnais.

De todo modo, argumenta Harvey, a flexibilização da produção e a virada financeira empreendidas pelos EUA tiveram impactos contraditórios sobre a situação do país. Por um lado, foi possível conferir maior liberdade ao capital - inclusive em termos de mobilidade geográfica -, disciplinar a força de trabalho e criar novas áreas de investimentos. Por outro, sua estrutura industrial foi profundamente impactada, na medida em que a produção em outros países tornou-se mais atrativa, gerando uma onda de deslocalizações para novos centros produtivos ${ }^{410}$. Dessa forma, "os Estados Unidos foram cúmplices do solapamento de seu domínio na manufatura ao desencadear por todo o globo o poder das finanças" ${ }^{\text {"411 }}$ e, por volta de 1980, eles já não eram mais hegemônicos nesse campo.

É necessário assinalar que essa asserção de Harvey deriva em parte das conclusões expostas por Arrighi em $O$ longo século $X X$. Para este, as fases cíclicas de expansão financeira assinalam a tentativa do país detentor da hegemonia mundial de manter sua posição, mas que no médio ou longo prazo se mostra infrutífera, já que a acumulação capitalista depende de uma retomada do crescimento na produção de mercadorias. Um novo centro dinâmico de acumulação, ao aproveitar as oportunidades abertas nessa fase, acaba, então, obtendo a hegemonia, reiniciando assim uma nova fase de expansão material.

Nesse sentido, o fato, assinalado por Harvey, de que os EUA caminham para "ser uma economia rentista com relação ao resto do mundo e uma economia de serviços no nível doméstico"412 poderia ser visto como uma ilustração dessa nova posição do hegemon (em declínio) no cenário mundial. Por outro lado, isso pode ser interpretado de acordo com o que propõe Chesnais. Este não está convencido da perda de hegemonia dos EUA: sua força está, entre outros fatores, exatamente em ter o aparato financeiro mais poderoso do mundo numa época de predomínio do regime financeirizado ${ }^{413}$. Esse ponto de vista daria coerência à

\footnotetext{
${ }^{409}$ Conforme citação da p. 110.

${ }^{410}$ Chesnais aponta os impactos perversos e contraditórios que a financeirização tem sobre a produção e o emprego de um modo geral para os países. Contudo, não parece enfatizar esses efeitos especificamente sobre os EUA, nem concebê-los como uma fragilização política do país.

Harvey, por outro lado, diz o seguinte: “A virada para a financialização envolveu muitos custos internos, como a desindustrialização, as fases de rápida inflação seguida pelo esmagamento do crédito e o desemprego estrutural crônico. Os Estados Unidos, por exemplo, perderam seu domínio na produção, exceto em setores como a defesa, a energia e o agronegócio" - HARVEY, O novo imperialismo, p. 150-151.

${ }^{411}$ Ibidem, p. 60.

${ }^{412}$ Ibidem, p. 61.

${ }^{413}$ Embora admita que a entrada da China no cenário mundial possa modificar isso, como apontado no Capítulo 3.
} 
seqüência do raciocínio de Harvey, que admite a capacidade da virada financeira em propiciar, se não uma solução, pelo menos sobrevida à hegemonia dos EUA:

Embora tivesse havido, portanto, fases (como a dos anos 1980) em que a hegemonia dos Estados Unidos foi abertamente questionada no plano doméstico e externo, por volta do final dos anos 1990, boa parte dessa dúvida havia se dissipado. A segurança dos Estados Unidos e seu domínio financeiro nos negócios do mundo estavam garantidos. ${ }^{414}$

As contradições inerentes à financeirização, contudo, geram instabilidade e não fornecem uma solução para o problema da sobreacumulação. Assim, a questão da retomada do crescimento no setor produtivo e da abertura de novos espaços de valorização do capital retornaram com força. Harvey detecta então o seguinte dilema: ou se abrem novos espaços para a valorização do capital ou novas fases de desvalorização sobrevirão. Essa situação crítica assinala um novo questionamento da hegemonia estadunidense, cujas raízes estão, conforme Arrighi, exatamente no emprego exagerado do capital financeiro como meio de afirmação do poder. O efeito seria uma guinada acentuada por parte dos EUA em direção a atitudes mais coercitivas, exercendo sua supremacia militar, como no caso examinado anteriormente de uma tentativa de controle direto das fontes de petróleo.

Essa instabilidade na hegemonia dos EUA, que não aparenta ainda ter se esgotado, torna prematuro concluir quem possui a posição mais acertada, Arrighi ou Chesnais, pois é difícil afirmar se a virada financeira dos EUA levará, a curto ou médio prazo, à sua derrocada, ou se consistirá numa solução mais durável apesar das contradições. De todo modo, no plano internacional, os apontamentos de Harvey e de Chesnais condizem. O capital financeiro se mostra cada vez mais predatório e volátil e milhões de pessoas empobrecem ou perdem seus empregos em razão dos ajustes impostos pelas instituições internacionais e das crises provocadas por ataques especulativos. As crises da dívida do Terceiro Mundo, por exemplo, continuam sendo usadas para tornar esses países mais permeáveis ao capital externo.

Enfim, o estado geral de sobreacumulação mal resolvido, aliado à guinada mundial rumo à financeirização, impele o capital a buscar estratégias para contorná-lo. Segundo Harvey, portanto, “aquilo que denomino 'acumulação via espoliação' tornou-se uma característica bem mais central no âmbito do capitalismo global (com a privatização como um

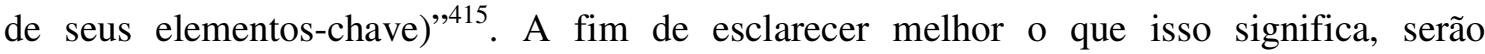

\footnotetext{
${ }^{414}$ HARVEY, O novo imperialismo, pp. 63-64.

415 Ibidem, p. 62.
} 
discutidos, a seguir, os elementos necessários para a compreensão do que é a acumulação por espoliação e sua relação com a financeirização. Do mesmo modo, ficará mais nítido também por que o neoliberalismo se impôs através da acumulação por espoliação e da financeirização e as teve como instrumentos preferenciais.

Muitos teóricos, sobretudo marxistas, se vêem às voltas com a questão da sobrevivência do capitalismo, de como um sistema tão contraditório, permeado por crises e reorganizações constantes, continua se reproduzindo. Com Harvey não é diferente, e por isso ele investiga os modos pelos quais se tenta evitar, contornar, ou atenuar as crises de sobreacumulação, já que estas são o principal fator endógeno de perturbação do capitalismo. Nesse sentido, argumenta que a lógica "econômica" do imperialismo precisa ser entendida no contexto mais amplo dos ajustes espaço-temporais que tentam lidar com os excedentes de capital, e no qual o Estado possui um papel fundamental. Desse modo, seria preciso compreender os processos geográficos mais amplos que envolvem a acumulação do capital em âmbito mundial e as modalidades de participação do Estado nessa dinâmica.

Os processos de circulação (de mercadorias em geral, incluindo a força de trabalho) sempre envolvem mudanças de localização, produzindo, na expressão de Harvey, "fricção da distância", de modo que "a atividade capitalista produz o desenvolvimento geográfico desigual” ${ }^{\wedge 16}$. Como os capitalistas buscam utilizar as vantagens competitivas dos diferentes espaços - tal como em relação a melhorias tecnológicas (e por vezes em substituição a estas) - surgem competições acirradas na busca por vantagens espaciais, dado que seu caráter de monopólio proporciona maior segurança, previsibilidade e tranqüilidade aos investimentos.

No entanto, o impulso à redução das barreiras espaciais e à aceleração do tempo de rotação do capital característico do desenvolvimento capitalista tem como uma de suas consequiências o ímpeto constante de transformação da escala geográfica da atividade capitalista. Por conseguinte, um espaço cada vez mais "globalizado" de valorização do capital resulta da própria evolução das forças da acumulação, indo na contramão dos monopólios

${ }^{416}$ HARVEY, O novo imperialismo, p. 82. 
geográficos. A importância desse processo é ressaltada nessa reafirmação (materialista) que Harvey faz ${ }^{417}$ :

Sem esses impulsos [à redução das barreiras espaciais], a escala em mutação do poder hegemônico (...) seria tanto materialmente impossível como teoricamente incompreensível. (...) Isso porém não significa, naturalmente, que as mudanças políticas sejam mera função dessas transformações materiais de relações espaciais as coisas são bem mais complexas. Porém, mudar relações espaciais de fato funciona como condição necessária que molda as reorganizações políticas que nos cercam. $^{418}$

A ampliação espacial da valorização do capital é, não obstante, um processo que encerra em si contradições, pois a fluidez do movimento de capital se materializa necessariamente em estruturas físicas no espaço, muitas vezes concentradas territorialmente. Como resultado, explica Harvey, o capital fixo incorporado à terra age na contramão das mudanças geográficas e da realocação das atividades capitalistas. Uma série de tensões decorre, pois, dos processos moleculares de acumulação do capital, entre fixidez e movimento, dinamismo e inércia, concentração e dispersão, etc. ${ }^{419}$.

Levando em conta a lógica e o funcionamento do capital financeiro, pode-se pensar que, por um lado, as exigências de fixidez da acumulação são uma limitação de seus imperativos de fluidez e de prazos curtos. Por outro lado, a dimensão especulativa e fíctícia do capital financeiro abre espaço para tentativas, ainda que limitadas e contraditórias, de se contornarem tais restrições, uma vez que se baseiam no rearranjo de riquezas já circulando nos mercados financeiros (independendo até certo ponto da geração efetiva imediata de lucros

\footnotetext{
${ }^{417}$ Note-se que a ressalva feita na citação quanto aos resultados políticos não serem mecanicamente derivados das mudanças materiais é essencial e vai no mesmo sentido da crítica de Chesnais, anteriormente exposta, ao fetichismo tecnológico. Mesmo que a própria mudança tecnológica e seus resultados não sejam vistos como pairando no ar, mas inseridos na própria dinâmica capitalista - de modo que as conseqüências políticas já poderiam ser interpretadas como o resultado do desenvolvimento do capitalismo "por si só" -, ainda assim há determinados processos, digamos, "genuinamente" políticos. Tais processos não podem ser determinados de antemão e conferem rumos específicos às tendências mais gerais. Nesse sentido, podem-se apontar tendências de mundialização e do surgimento de uma crise de hegemonia, mas não como elas se darão de fato ou mesmo se elas se efetivarão.

Chesnais mostra como a virada para a dominância financeira, embora fosse uma resposta a condições econômicas dos anos 1970 (crise de sobreacumulação/crise do fordismo), envolveu uma série de ações políticas, empreendidas por atores e instituições, que dificilmente poderiam ser imediatamente derivadas das exigências da acumulação. Foi necessário, segundo expressão do próprio autor, um "golpe de estado" da finança que instaurasse uma "ditadura dos credores" - Cf. CHESNAIS, "O capital portador de juros (...)”, pp. 39-40.

${ }^{418}$ HARVEY, O novo imperialismo, p. 86.

${ }^{419}$ Cf. Ibidem, p. 87. Sobre as tendências contraditórias entre concentração e dispersão, ver também HARVEY, Limits to Capital, pp. 417-19.
} 
de determinado empreendimento em que se investiu); e na fluidez dos investimentos permitida pela grande liquidez dos mercados financeiros ${ }^{420}$.

Em resumo, a busca crescente por parte dos capitalistas de vantagens espaciais explorando as desigualdades geográficas - e as contradições existentes entre a fixação do capital no espaço e as exigências de fluidez da valorização do capital, geram pressões sobre os Estados. Estes são, assim, impelidos a assumir uma posição ativa na manutenção ou criação de condições para a acumulação capitalista. Evidentemente, segundo Harvey, há condições institucionais mais propícias ao desenvolvimento de atividades capitalistas do que outras, como as que garantam a propriedade privada, os contratos firmados e a validade da moeda ${ }^{421}$. Assim, um Estado burguês, com seu devido monopólio da violência, garantidor do funcionamento do mercado, que arbitre os conflitos de classe e de facções do capital, que assegure a oferta de dinheiro e propicie os negócios e relações comerciais externos, representa a condição preferida para a atividade capitalista ${ }^{422}$.

Contudo, há uma variedade de arranjos institucionais possíveis para isso. Além disso, nem todos os Estados agem dessa maneira "apropriada", de modo que a sorte da acumulação de capital depende em muito de como o Estado é, foi e será capaz de apoiar ou contrariar os pressupostos da acumulação:

O Estado (...) tem tido um papel-chave na acumulação original ou primitiva, usando seus poderes não apenas para formar a adoção de arranjos institucionais capitalistas mas também para adquirir e privatizar ativos como a base original da acumulação do $_{\text {capital. }}{ }^{423}$

$* * *$

\footnotetext{
${ }^{420}$ Quanto a isso, é interessante notar um comentário de Marx sobre o capital fixo: "A circunstância, porém, de que os meios de trabalho estão localmente fixados, com suas raízes fincadas na base fundiária, confere a essa parte do capital fixo um papel próprio na economia das nações. Não podem ser enviados para o exterior, nem circular como mercadorias no mercado mundial. Os títulos de propriedade sobre esse capital fixo podem mudar de mão, ele pode ser comprado e vendido e, nessa medida, circular idealmente [Nos circuitos financeiros, esse capital fixo (na verdade o título a ele correspondente) está sujeito, assim, do ponto de vista individual, a valorizações especulativas e a ser rapidamente passado adiante - I.L.]. Esses títulos de propriedade podem até circular em mercados estrangeiros, por exemplo, sob a forma de ações. Mas, (...) não muda a proporção entre a parte imóvel (...) e a parte móvel [do capital fixo]” - MARX, O Capital, Livro II (tomo III), cap. 8, p. 120.

421 Importante frisar que, para o capital financeiro especificamente, isso é ainda mais crucial, já que sua circulação depende de uma forma muito bem definida de regulamentação, na medida em que se baseia em contratos e em "produtos" muitas vezes existentes só juridicamente.

${ }^{422} \mathrm{Cf}$. HARVEY, O novo imperialismo, pp. 79-80.

${ }^{423}$ Ibidem, p. 80.
} 
O problema que remete mais diretamente à acumulação por espoliação e ao imperialismo, portanto, é o de estabelecer o que acontece quando os processos moleculares de acumulação ultrapassam, ou exigem que se ultrapasse, as fronteiras do Estado político. Mais especificamente, o que acontece com capitais excedentes que não encontram emprego lucrativo no território nacional. A recusa da burguesia em absorver internamente a sobreacumulação nos anos 1970, através de reformas e desvalorizações, acabou gerando novos impulsos de ampliação geográfica da atuação do capital (pressões imperialistas), no intuito de "exportar" a sobreacumulação e evitar agitações políticas domésticas. Como conclui Harvey, "quase certamente surgem conflitos geopolíticos a partir dos processos moleculares de acumulação do capital" ${ }^{424}$.

Já foi apresentada a idéia básica de Harvey sobre os deslocamentos/ajustes espaçotemporais como estratégia para lidar com os problemas ou crises de sobreacumulação do capital. Quando o foco é o imperialismo, evidentemente enfatiza-se a questão do ajuste espacial - embora o binômio espaço-tempo nunca seja deixado de lado. Assim, os excedentes de capital e de força de trabalho que não podem ser conjugados de forma lucrativa nos limites territoriais do Estado precisam ser enviados a novos espaços, nos quais possam continuar se valorizando. Harvey apresenta duas grandes alternativas para isso.

Primeiramente, podem-se buscar mercados para escoar as mercadorias excedentes, ou seja, o capital-mercadoria que encontra dificuldades de dar seu "salto mortal" em condições favoráveis. Contudo, essa é uma solução bastante limitada, pois transfere o problema das mercadorias para os meios de pagamento ou outras mercadorias recebidos do exterior através do comércio. No caso de o outro país não ter meios de pagamento suficientes, ele pode obter crédito ou auxílios financeiros, um recurso mais eficaz em contextos de desigualdades geográficas mais acentuadas ${ }^{425}$. Porém, salienta Harvey, o recurso ao crédito torna os novos territórios alvos de fluxos de capitais especulativos e fictícios, cujo efeito pode ser tanto o de estimular como o de minar o desenvolvimento. Até mesmo desvalorizações podem ser impostas, assim como a subordinação do país pela dívida - forçando-o a novas absorções de capitais excedentes e a compensações ao credor por eventuais desvalorizações ${ }^{426}$.

\footnotetext{
${ }^{424}$ HARVEY, O novo imperialismo, p. 93.

${ }^{425}$ Essa opção, aliás, parece mais interessante, na medida em que torna o país comprador também um devedor, que ainda deve pagar juros.

${ }^{426}$ Cf. Ibidem, p. 101. Chesnais também mostra como a dívida pública se torna uma armadilha que estabelece uma hierarquia entre os países.
} 
A segunda alternativa apresentada é a exportação de capital, e de força de trabalho, cujos efeitos são distintos e mais duradouros. Esse processo é que está, no marxismo, classicamente associado ao imperialismo. "Nesse caso - diz Harvey -, excedentes de capital e trabalho são enviados alhures para pôr em movimento a acumulação do capital no novo espaço regional" ${ }^{427}$. Ao iniciar empreendimentos capitalistas em outro território, o Estado original não só escoa seu capital monetário sobreacumulado, como gera igualmente uma demanda para suas mercadorias. Enquanto o capitalismo não amadurece nos novos territórios, o que pode levar muitos anos, o país de origem se beneficia dessa situação. Contudo, tão logo isso ocorra, aparecem novos centros de acumulação que rivalizam com os antigos, tendendo a reativar o problema ${ }^{428}$.

Dois desfechos possíveis são apontados por Harvey para essa dinâmica. Ou novas ordenações espaço-temporais vão se sucedendo, absorvendo os excedentes e estabilizando o sistema por algum tempo; ou então, se essa dinâmica não ocorrer ou quando se esgotar, pode surgir uma competição internacional mais acirrada devido à concorrência entre os centros de acumulação, tanto novos como antigos. Nesse caso, sérias crises de desvalorização sobrevêm nos países mais fracos, e mesmo a eclosão de guerras ${ }^{429}$ pode acontecer, evidenciando os limites dos ajustes espaço-temporais na resolução do problema de sobreacumulação.

Diante de tal acirramento da competição, Harvey considera a virada financeira dos EUA uma estratégia relevante para a manutenção de sua hegemonia, revelando a importância das estruturas financeiras e estatais. As idéias de Peter Gowan são retomadas para mostrar que as transformações do capitalismo pós-1973 atualizaram as estratégias imperialistas, dando origem a:

Um forte regime financeiro governado por Wall Street/Tesouro dos Estados Unidos, que detinham poderes de controle sobre instituições financeiras globais (como o FMI) e podiam fazer ou desfazer muitas economias estrangeiras mais fracas por meio de manipulações do crédito e práticas de gerenciamento da dívida. Esse regime monetário e financeiro (...) [teve como efeito] o fortalecimento do poder financeiro dos Estados Unidos (sempre que possível em aliança com outros) no sentido de forçar a abertura de mercados, em particular para fluxos de capital e

\footnotetext{
${ }^{427}$ HARVEY, O novo imperialismo, p. 101.

${ }^{428}$ Em outro lugar, Harvey analisa quatro possibilidades de resposta a essa situação de sobreacumulação - Cf. HARVEY, Limits to Capital, p. 432.

${ }^{429}$ Não se deve esquecer que a destruição gerada pelas guerras abre novos e importantes caminhos para a acumulação. Segundo Harvey, "o mundo foi salvo dos horrores da grande depressão, não por algum tipo de 'new deal' glorioso ou de passe de mágica da ciência econômica keynesiana nos tesouros [treasuries] do mundo, mas pela destruição e morte da guerra mundial” - HARVEY, Limits to Capital, p. 444.
} 
financeiros (...) e impor outras práticas neoliberais (que culminaram na OMC) a boa parte do resto do mundo. ${ }^{430}$

Desse modo, percebe-se que o poder financeiro é utilizado, em primeiro lugar, como instrumento político para abrir caminho à exportação do capital pelos países centrais. Em segundo lugar, por meio do crédito e dos mercados financeiros, o capital financeiro dá suporte a empreendimentos no exterior, estimulando a acumulação em geral e aliviando as pressões de sobreacumulação internas. Ele permite igualmente a realocação de capital de um setor a outro, coordenando a dinâmica da acumulação. Por fim, mesmo a atividade financeira altamente especulativa, que:

\footnotetext{
Nada tem a ver com facilitar o investimento em atividades produtivas (...) tem profundos impactos na dinâmica geral da acumulação do capital e, de modo mais específico, na recentração do poder político econômico primordialmente nos Estados Unidos, mas também nos mercados financeiros de outros países nucleares [como concordaria Chesnais - I.L.] $]^{431}$
}

Por outro lado, o Estado (e suas instituições), segundo Harvey, constitui, no plano da política territorial e do império, a entidade mais apta a orientar as forças da acumulação para preservar o padrão de assimetrias das trocas mais vantajoso para os interesses capitalistas. Os Estados centrais promovem o comércio injusto com os países mais pobres, uma prática tipicamente imperialista. Nesses termos, o imperialismo "equivale a empurrar sobre os outros arranjos e condições institucionais, em geral em nome do bem-estar universal" ${ }^{, 432}$. Atualmente, isso é feito, em grande medida, pelo alto grau de controle que os países centrais exercem sobre a arquitetura financeira mundial. Mas esse poder financeiro só pode operar como uma dimensão importante da dominância financeira, e Chesnais enfatiza isso, porque o resto do mundo está interconectado por meio de uma rede de instituições financeiras e governamentais, ou seja, porque se vive hoje sob a desregulamentação e liberalização financeiras e sob uma aceleração da mundialização do capital. Como resume Harvey:

O quadro geral que surge, por conseguinte, é de um mundo espaço-temporal entrelaçado de fluxos financeiros de capital excedente com conglomerados de poder político e econômico em pontos nodais chave (Nova York, Londres, Tóquio) que buscam seja desembolsar e absorver os excedentes de maneiras produtivas (...), seja

\footnotetext{
${ }^{430}$ HARVEY, O novo imperialismo, pp. 108-109.

${ }^{431}$ Ibidem, p. 111.

${ }^{432}$ Ibidem, p. 112.
} 
usar o poder especulativo para livrar o sistema da sobreacumulação mediante a promoção de crises de desvalorização em territórios vulneráveis. ${ }^{433}$

Isso mostra que o capitalismo não se reproduz apenas por meio de ordenações espaçotemporais que dão um destino produtivo aos excedentes de capital, mas também de desvalorizações e destruições administradas. A aliança do poder do Estado com o capital financeiro promove, assim, uma "acumulação por outros meios", ou seja, modos complementares, ou alternativos, aos processos moleculares de propiciar a acumulação do capital. Sob esse ponto de vista, o capital financeiro é apreendido sobretudo na sua dimensão eminentemente destrutiva e improdutiva, em sua ação, por exemplo, de promover desvalorizações forçadas visando se apropriar de ativos a baixos custos ${ }^{434}$.

Viu-se que a essa acumulação por outros meios, Harvey dá o nome de "acumulação por espoliação". Esse conceito é formulado à luz das considerações de Rosa Luxemburgo sobre a acumulação ${ }^{435}$. Ela reconhece nesta um duplo aspecto. De um lado, há a acumulação como um processo econômico "puro", por meio da exploração da mais-valia ("processos moleculares da acumulação", segundo a terminologia empregada por Harvey). A apropriação de valor assenta-se na relação entre capitalista e trabalhador no âmbito da produção e da troca de equivalentes, em que aparentemente reinaria a "igualdade", sendo necessária a análise dialética para demonstrar que o direito de propriedade se interverte em exploração alheia. De outro lado, encontra-se a relação do capitalismo com outros modos de produção, na qual a violência, a fraude e a expropriação direta de riqueza imperam. O colonialismo, a guerra, e um sistema internacional de empréstimos seriam seus métodos predominantes, o que remete imediatamente aos procedimentos da acumulação primitiva apontados por Marx no capítulo XIV de $O$ Capital.

${ }^{433}$ HARVEY, O novo imperialismo, pp. 112-113.

${ }^{434}$ Marx refere-se a um processo similar de apropriação de ativos ocorrido, não através de desvalorizações forçadas, mas nas próprias fases cíclicas de crise: “[nas fases desfavoráveis do ciclo industrial] caem os preços dos títulos estatais e dos outros papéis de crédito. Este é o momento em que os capitalistas monetários compram em massa esses papéis desvalorizados, que nas fases posteriores voltam logo a subir a seu nível normal e acima dele. Então eles são vendidos e assim uma parte do capital monetário do público é apropriada" - MARX, $O$ Capital, Livro III (tomo V), cap. 31, p. 39.

${ }^{435}$ HARVEY, op., cit., cap. 4. 
Esse segundo aspecto também se relaciona - retomando as proposições de $O$ manifesto comunista sobre a dinâmica capitalista - ao que se chamou aqui de "expansão extensiva" do capitalismo. A principal idéia de Luxemburgo a esse respeito adotada por Harvey é a de que o capitalismo precisa permanentemente desse "outro", desse território exterior a ser assimilado, a fim de se estabilizar e de continuar seus processos moleculares. Invocam-se, por exemplo, as considerações de Marx sobre o exército industrial de reserva, para mostrar como ali está contida a mesma idéia. Tanto a demanda por mais força de trabalho pode precisar da incorporação de uma força de trabalho "latente" ainda não empregada em moldes capitalistas, como o progresso tecnológico pode dispensar seu emprego, empurrando os trabalhadores para fora do sistema (ou talvez os reincorporando posteriormente).

O fundamento dessa dinâmica de expansão "para fora" assenta-se, evidentemente, nos imperativos capitalistas de uma acumulação incessante. As contradições desse movimento levam a crises de sobreacumulação ${ }^{436}$, a um limite do crescimento, que necessitam de uma solução para que o capitalismo continue a se desenvolver. Porém, Harvey argumenta que é possível tanto recorrer a um exterior pré-existente - seja uma formação social pré-capitalista, como sugere Luxemburgo, seja um setor do capitalismo que ainda não esteja submetido à proletarização (privatização da educação, por exemplo) - como produzir ativamente essa exterioridade.

Assim, a inclusão de setores do próprio capitalismo no rol de "exterioridades" e a concepção da produção ativa destas reflete uma contribuição importante do pensamento de Harvey sobre a questão. Para ele, os pressupostos de Marx "relegam a acumulação baseada na atividade predatória e fraudulenta e na violência a uma 'etapa original' tida como não mais relevante ou, como no caso de Luxemburgo, como de alguma forma 'exterior' ao capitalismo como sistema fechado" ${ }^{437}$. Levando-se essa crítica em conta, a acumulação por espoliação não se limitaria a um momento inicial do capitalismo, criando as condições de surgimento deste, mas se fundaria numa "dialética “interior-exterior",438, pois que o "outro" que ela visa assimilar não está necessariamente apartado dele, nem existe independentemente dele ${ }^{439}$.

\footnotetext{
${ }^{436}$ Rosa Luxemburgo recorre à tese do subconsumo como explicação, o que Harvey rejeita em benefício da tese da sobreacumulação de capital: "poucos aceitariam hoje a teoria do subconsumo de Luxemburgo como explicação das crises" e "o peso dos dados histórico-geográficos do século XX adapta-se amplamente ao argumento da sobreacumulação" - HARVEY, O novo imperialismo, pp. 116 e 118 respectivamente.

${ }^{437}$ Ibidem, p. 120.

${ }^{438}$ Ibidem, p. 118.

${ }^{439}$ Esse raciocínio dialético não deixa de guardar semelhanças com o de Francisco de Oliveira e com o de Caio Prado Jr. quanto à essa desconstrução do "dentro/fora". Para Prado Jr., a formação social do Brasil colonial
} 
Nesse sentido, a acumulação por espoliação pode operar o tempo todo como complemento à reprodução ampliada do capital. Não obstante, há momentos em que ela se torna especialmente necessária. Uma vez que as possibilidades internas de investimento se esgotam e que os ajustes espaço-temporais voltados para o exterior também já não podem, ou ainda não podem, satisfatoriamente dar origem a novos empreendimentos produtivos, a acumulação por espoliação adquire proeminência na dinâmica capitalista exatamente pela possibilidade de introduzir novas formas de investimento e de ajustes espaço-temporais. Por isso, e também pelo papel crucial do Estado nos mecanismos de espoliação, ela se relaciona tão estreitamente com o imperialismo.

Harvey enumera os processos relativos à acumulação primitiva apresentados por Marx mostrando como eles dependem da ação estatal, para, em seguida, revelar como eles continuam a agir por meio da acumulação por espoliação. Embora eles sejam muito diferentes entre si, é certo que as atividades direta ou indiretamente relacionadas ao capital financeiro como a usura, a dívida pública e até o sistema de crédito - ocupam uma posição importante atualmente. Eles são inclusive aperfeiçoados nesse sentido: "alguns dos mecanismos de acumulação primitiva (...) foram aprimorados para desempenhar hoje um papel de destaque bem mais forte do que no passado. O sistema de crédito e o capital financeiro se tornaram (...) grandes trampolins de predação, fraude e roubo" ${ }^{\text {440 }}$, sobretudo a partir de 1973 - quando começa a ascensão do neoliberalismo. Todo tipo de valorização fraudulenta de ações, de promoção do endividamento (tanto público como pessoal), de falsos esquemas financeiros, etc. são considerados características centrais do capitalismo contemporâneo e não apenas fatos isolados. Além disso, um destaque especial é concedido aos ataques especulativos efetuados pelas instituições da finança, considerados "a vanguarda da acumulação por espoliação em épocas recentes" ${ }^{441}$.

Percebe-se, desse modo, que uma série de processos que Chesnais identifica como parte integrante do regime financeirizado tem sua importância reconhecida por Harvey, que os unifica e articula a partir do conceito de acumulação por espoliação. Confere-se, assim, um

estava vinculada ao funcionamento do sistema capitalista mundial, de modo que, apesar de não abrigar relações sociais propriamente capitalistas, a colônia brasileira se integrava ao processo de acumulação de capital como um todo. Oliveira, por sua vez, critica a "razão dualista" que concebe o "atrasado" e o "moderno" como pólos radicalmente opostos. Não se trataria de modernizar o atraso, pois que o primeiro produz dialeticamente o segundo, formando uma unidade. Cf. PRADO JR., Formação do Brasil contemporâneo e OLIVEIRA, Crítica à razão dualista.

${ }^{440}$ HARVEY, O novo imperialismo, p. 122.

${ }^{441}$ Ibidem, p. 123. 
significado mais preciso, bem como um tratamento teórico mais aprofundado, a todos esses fenômenos.

Há, assim, uma nuance entre os autores. Chesnais, embora também enfatize o funcionamento predatório do capital financeiro ${ }^{442}$, contribui mais para a compreensão de seu processo de reprodução e circulação e para a avaliação do impacto que sua dominância possui nos processos moleculares de acumulação. A sua face destrutiva parece ser compreendida mais em termos de conseqüências do regime financeirizado ou de características próprias de seu funcionamento, tal como as crises e as instabilidades crônicas. Desse modo, a dimensão política da dominância financeira é vista de certa forma como pressuposto da ação do capital financeiro (o "golpe de Estado" da finança) ou como resultado final de suas operações (reforçando o poder da finança), o que de toda forma se liga mais ou menos diretamente à ação dos atores da finança ${ }^{443}$.

Harvey, por sua vez, ao adotar a perspectiva da acumulação por espoliação, ilumina uma face política dos processos envolvidos na financeirização que se baseia na dimensão destrutiva e predatória do capital financeiro em ação (não somente no resultado ou pressuposto de sua ação, mas na sua própria circulação). Os efeitos sociais e políticos desse capital financeiro em ação podem ser, por falta de termo melhor, "passivos" ou "ativos",444. "Passivos", na medida em que sua ação espoliativa - que visa resolver o problema econômico de reanimar a acumulação do capital através da oferta de ativos a baixo custo para o capital excedente - acaba engendrando, pela destruição que provoca e como uma espécie de subproduto necessário, a subordinação de pessoas (efeito sobre a luta de classes) ou países (contribuição ao imperialismo), por exemplo. Podem ser "ativos", como no intuito neoliberal de restaurar internamente o poder de classe, quando seus processos predatórios almejam de

\footnotetext{
${ }^{442}$ Por exemplo, na referência à "imensa capacidade que os 'mercados financeiros' têm de puramente causarem danos. Esses mercados (...) [são] instituições habilitadas por seus mandantes a fazerem lucros financeiros (...) num mundo onde a regulação financeira foi destruída de modo relativamente consciente" - CHESNAIS, $A$ mundialização do capital, pp. 268-269.

${ }^{443}$ Harvey aponta duas dimensões no conceito de capital financeiro: um determinado processo de circulação do capital e um bloco de poder no seio da burguesia. Chesnais, por ter grande influência de Hilferding, trabalha muito na chave do bloco de poder. Talvez por isso sua visão sobre a dimensão política da financeirização esteja mais atrelada à ação dos agentes financeiros.

${ }^{444}$ A dimensão "ativa" estaria mais claramente presente em Chesnais. A dimensão "passiva" ficaria mais nítida na análise de Harvey, já que o conceito de acumulação por espoliação liga inextricavelmente ação política e econômica.
} 
forma mais ou menos consciente e direta reestruturar o Estado ou "dobrar" a classe trabalhadora enfraquecendo suas formas de organização ${ }^{445}$.

Dentre os mecanismos espoliativos considerados inteiramente novos, nos quais se incluem direitos de propriedade intelectual, encontramos igualmente processos relacionados à financeirização. As privatizações, por exemplo, medidas amplamente empregadas pelo Estado neoliberal, são consideradas por Harvey a vanguarda da acumulação por espoliação, ao abrirem novos espaços de valorização dentro das próprias sociedades capitalistas. É também o que aponta Chesnais ao afirmar que:

Atualmente, é no movimento de transferência, para a esfera mercantil, de atividades que até então eram estritamente regulamentadas ou administradas pelo Estado, que o movimento de mundialização do capital encontra suas maiores oportunidades de investir. A desregulamentação dos serviços financeiros num primeiro tempo; depois, nos anos 80, o início da desregulamentação e privatização dos grandes serviços públicos (...) representam a única 'nova fronteira' aberta para o IED, sobre a base das atuais relações entre os países e entre as classes sociais. ${ }^{446}$

Por outro lado, Chesnais também relaciona as privatizações aos constrangimentos políticos sofridos pelos Estados - em razão de seu endividamento - e, mais amplamente, à força expansiva do capital financeiro. Para ele, "a propensão do capital portador de juros para demandar da economia 'mais do que ela pode dar' é (...) uma das forças motrizes da desregulamentação do trabalho, assim como das privatizações" ${ }^{447}$. Nesse sentido, podem-se avaliar as privatizações sob um duplo aspecto: elas são tanto um mecanismo de espoliação que abre novas oportunidades para o capital sobreacumulado em geral, como conseqüência da ampliação do poder específico do capital financeiro ${ }^{448}$.

Segundo Harvey, o que a privatização tem em comum com os diversos outros mecanismos de acumulação por espoliação é que:

\footnotetext{
445 Sobre essa questão, Paulani e Almeida Filho comentam o seguinte: "[Para Harvey], a vanguarda dessa acumulação por espoliação estaria hoje com os fundos de derivativos e outras instituições do mercado financeiro por sua capacidade de engendrar ataques especulativos. As punções e o caráter insaciável da finança aos quais se refere Chesnais não são estranhos a esta análise de Harvey, mas parecem aqui melhor qualificados, além de inseridos numa problemática mais ampla, que envolve não apenas as formas de regulação social, mas o entrelaçamento dessas formas com o poder do Estado e com as contradições da reprodução sistêmica em nível global" - PAULANI e ALMEIDA FILHO, "Regulação e social e acumulação por espoliação - reflexão sobre as teses da financeirização e a caracterização do capitalismo contemporâneo", p. 12.

${ }^{446}$ CHESNAIS, A mundialização do capital, p. 186.

${ }^{447}$ CHESNAIS, "O capital portador de juros (...)", p. 61.

${ }^{448}$ Um recurso alternativo/paralelo à privatização seria, por exemplo, a injeção direta de matérias-primas baratas no sistema, tais como o petróleo, reduzindo os custos de produção e, portanto, aumentando a lucratividade. Assim, a Guerra do Iraque pode ser facilmente inserida no leque de manifestações da acumulação por espoliação.
} 
[Eles liberam] um conjunto de ativos (incluindo força de trabalho) a custo muito baixo (e, em alguns casos, zero). O capital sobreacumulado pode apossar-se desses ativos e dar-lhes imediatamente um uso lucrativo (...) [de modo que] se o capitalismo vem passando por uma dificuldade crônica de sobreacumulação desde 1973, então o projeto neoliberal de privatização de tudo faz muito sentido. ${ }^{449}$

Essas formas da acumulação por espoliação funcionam de modo semelhante à acumulação primitiva, pois adicionam ao sistema novas "áreas" de valorização. Outra forma de proceder, porém, é apelando a meios destrutivos, impingindo desvalorizações dos ativos de capital e trabalho já existentes, para serem apropriados pelo capital sobreacumulado e, posteriormente, revalorizados ${ }^{450}$. Esse parece ser o método por excelência da finança, já que crises orquestradas e administradas pelo sistema financeiro internacional e por Estados se tornaram muito freqüentes e relevantes atualmente ${ }^{451}$. A crise asiática de 1997-98 é citada como um exemplo típico desse processo. Mas, diante do risco de alastramento da crise, "uma das principais funções das intervenções do Estado e das instituições internacionais é orquestrar desvalorizações para permitir que a acumulação por espoliação ocorra sem desencadear um colapso geral’ ${ }^{, 452}$.

A exposição de Harvey permite, então, elaborar uma espécie de tipologia das diferentes formas assumidas pela acumulação por espoliação. O primeiro tipo se assemelharia propriamente à acumulação primitiva, no sentido de instaurar relações capitalistas. Classicamente, isso ocorre em um território diferente, com uma formação social nãocapitalista (ex. colonização ou, mais recentemente, a abertura da China e da União Soviética). Porém, ainda assim há diferença em relação à acumulação primitiva - o que justifica a não utilização do mesmo termo para sua designação -, pois não se trata de um processo endógeno, e sim imposto de fora pelo próprio capitalismo. À luz de Caio Prado $\mathrm{Jr}^{453}$, por exemplo, conclui-se que o Brasil colonial está inserido no capitalismo mundial em expansão, ou seja, se desenvolve a partir do capitalismo já constituído, e não das próprias relações sociais locais (embora do ponto de vista local possa haver acumulação primitiva para empreendimentos

\footnotetext{
${ }^{449}$ HARVEY, O novo imperialismo, p. 124

${ }^{450}$ Harvey evoca Marx para enfatizar que processos de desvalorizações que atingem o valor de troca deixando intactos os valores de uso (como é, em geral, o caso das desvalorizações via finança) possuem grande potencial para reiniciar o ciclo de reprodução do capital - Cf. HARVEY, Limits to Capital, p. 200-1.

${ }^{451}$ A crise de 2008 não parece ter sido propriamente fruto da maquinação das instituições financeiras com o objetivo de produzir desvalorizações, já que muitas destas foram seriamente afetadas (assim como países centrais do capitalismo). Ainda assim, as que se mantiveram de pé obtiveram grandes possibilidades de se aproveitar da situação, adquirindo ativos de toda espécie a baixíssimo custo e efetuando aquisições de seus concorrentes.

${ }^{452}$ HARVEY, O novo imperialismo, p. 126.

${ }^{453}$ Ver p. 152, nota 439.
} 
capitalistas locais). Não tão classicamente, esse tipo de acumulação por espoliação se manifesta pela instauração de relações propriamente capitalistas ("proletarização", nos termos de Harvey) em setores da sociedade capitalista que ainda não as possuíam. É o caso emblemático das privatizações.

O segundo tipo de mecanismo de acumulação por espoliação, entretanto, não se parece tanto com a acumulação primitiva. O exemplo claro é a ação destrutiva do capital financeiro: as desvalorizações de ativos promovidas já se dão em âmbito capitalista, mas de forma predatória ${ }^{454}$. Elas não iniciam propriamente relações capitalistas, porém abrem oportunidades para o capital sobreacumulado que até então não existiam ou não eram viáveis economicamente $^{455}$. Algo análogo ocorre com a dívida pública, sendo a crise da dívida do terceiro mundo particularmente ilustrativa: estimulou-se a contração de empréstimos em dólar - já como forma de escoar excedentes de capital monetário - que eram atrelados aos juros dos EUA. Quando o FED multiplicou por três ou mesmo por quatro a taxa de juros, a dívida tornou-se impagável por um efeito bola-de-neve ${ }^{456}$, de modo que, mesmo baixando a taxa de juros posteriormente, criou-se uma fonte permanente de extração de riqueza desses países.

Se a acumulação por espoliação consiste em instrumento fundamental para que a reprodução ampliada tenha início, seja retomada ou se expanda, e se os mecanismos financeiros agem atualmente nos principais processos espoliativos - inclusive com o objetivo de restaurar o poder das classes dominantes -, tem-se aí a confirmação do papel de destaque que a virada financeira possui no capitalismo contemporâneo. Não é à toa que Harvey conclui o seguinte: “o cordão umbilical que une a acumulação por espoliação e reprodução expandida é o que lhe dão o capital financeiro e as instituições de crédito, como sempre com o apoio dos

\footnotetext{
${ }^{454} \mathrm{O}$ germe dessa concepção da acumulação por espoliação já está em Limits to Capital, onde Harvey afirma: "Mas quando o capitalismo esgota as possibilidades de acumulação primitiva às expensas das formações sociais pré-capitalistas e intermediárias, ele precisa buscar em outros lugares novas fontes de força de trabalho. No fim, ele tem apenas um lugar para ir. Ele deve se canibalizar" - HARVEY, Limits to Capital, pp. 437-8.

${ }^{455}$ A distinção feita aqui entre os dois "tipos" de acumulação por espoliação fica clara na seguinte passagem: "a acumulação primitiva que abre caminho à reprodução expandida [ou acumulação por espoliação do primeiro tipo - I.L.] é bem diferente da acumulação por espoliação [do segundo tipo - I.L.] que faz ruir e destrói um caminho já aberto" - HARVEY, O novo imperialismo, p. 135.

${ }^{456}$ Cf. CHESNAIS, "O capital portador de juros(...)", pp. 39-40.
} 
poderes do Estado" 457 . Isso é tanto mais verdade quando se considera a análise de Chesnais. A dificuldade para se compreender o papel do capital financeiro reside no fato de que ele se situa na fronteira entre processos econômicos e extra-econômicos; ele tanto é parte da reprodução ampliada (e se alimenta dela), entrando na circulação geral do capital, como cria as condições para ela, agindo espoliativamente na condição de instrumento político direto ${ }^{458}$.

A parte final da citação acima, porém, não é fortuita. A participação ativa do Estado nos processos espoliativos revela como estes são importantes também para a construção ou fortalecimento da hegemonia dos países centrais. Assim, para empregar os termos de Harvey, se, por um lado, a acumulação por espoliação responde às exigências da dinâmica de valorização do capital (“lógica capitalista” - ou econômica), por outro lado, ela é igualmente um instrumento utilizado pelos Estados para alcançarem seus objetivos geopolíticos específicos, tal como a Guerra do Iraque para os EUA ("lógica territorial" - ou estatal).

Desse modo, a resposta à indagação que Harvey se coloca de "por que a acumulação por espoliação sai dessa condição clandestina e se torna a forma dominante de acumulação com respeito à reprodução expandida?" ${ }^{459}$ passa inevitavelmente por dois aspectos.

Primeiramente, pelo fato de que a crise de sobreacumulação dos anos 1970 não foi resolvida, tornando-se crônica. Seguiu-se, portanto, uma intensificação dos mecanismos de espoliação como forma de lidar com essa situação - uma vez que as burguesias locais conseguiram evitar reformas internas. Assim, "o principal veículo dessa mudança foi a financialização e a orquestração (...) de um sistema financeiro internacional capaz de desencadear de vez em quando surtos de brandos a violentos de desvalorização e de acumulação por espoliação"460.

Depreende-se da obra de Chesnais, contudo, que, contraditoriamente, a financeirização é em grande medida a responsável pela perpetuação dos problemas de sobreacumulação. As "punções" da finança sobre o capital produtivo inibem os reinvestimentos na produção ao mesmo tempo que criam uma massa de capital monetário em busca de aplicação (sobreacumulação de capital monetário). Além disso, o socorro por parte de organizações

\footnotetext{
${ }^{457}$ HARVEY, O novo imperialismo, p. 126.

458 Admitindo-se, portanto, que o capital financeiro é capaz de se apropriar imediatamente de riquezas já produzidas (inclusive de formações pré-capitalistas), sem passar diretamente pelos processos moleculares de acumulação do capital, obtém-se um argumento adicional para a defesa da posição de Chesnais em relação à crítica de Prado (ver p. 16).

${ }^{459}$ HARVEY, O novo imperialismo, p. 127.

${ }^{460}$ Ibidem, p. 127.
} 
internacionais e governos a empresas e a instituições financeiras, quando do estouro das enormes bolhas de capital fictício, evitam a "depuração" da economia. Por conseguinte, o processo da crise não se completa inteiramente com a fase de desvalorizações que daria impulso a um novo ciclo de crescimento, perpetuando o problema e iniciando novas bolhas.

O segundo aspecto da resposta reside na dinâmica concorrencial da política interestatal. Adicionalmente ao uso esporádico de mecanismos espoliativos pelos países na tentativa de obter vantagens extras na competição internacional, os EUA, como hegemon ameaçado, tendem a utilizar a acumulação por espoliação para manter sua posição: apoderando-se de regiões estratégicas para a obtenção de matérias-primas essenciais, ou mesmo submetendo, pelo seu poderio financeiro, outros países ao pagamento de rendas - por exemplo, por meio da dívida pública ${ }^{461}$. Além disso, há países buscando desenvolver-se economicamente e integrar-se ao sistema, como a China, utilizando a espoliação a fim de criar condições para a produção capitalista ou de "cortar caminho" no processo de acumulação. Neste caso, "a acumulação por espoliação pode ser aqui interpretada como o custo necessário de uma ruptura bem-sucedida rumo ao desenvolvimento capitalista com o forte apoio dos poderes de Estado. As motivações podem ser internas (como no caso da China) ou impostas a partir de fora" ${ }^{\text {462 }}$, mas na maioria dos casos há uma combinação de motivações internas e de pressões de externas.

Por fim, a pergunta de Harvey ainda contém um aspecto metodológico importante. Se, em Condição pós-moderna, ele analisa a evolução histórica do capitalismo principalmente a partir da forma de produção de mercadorias, definindo um modo flexível de acumulação, em O novo imperialismo, ele recorre propriamente ao padrão de acumulação do capital para definir as mudanças ocorridas. Por trás da periodização política feita no início do livro passagem da "hegemonia norte-americana" para a "hegemonia neoliberal"463 -, o que parece de fato assinalar a transformação do capitalismo, e caracterizar esse imperialismo neoliberal $^{464}$, é a ascensão da acumulação por espoliação ao primeiro plano relativamente aos

461 Segundo Harvey: "as intervenções militares são a ponta do iceberg imperialista. O poder hegemônico do Estado costuma ser empregado para garantir e promover arranjos institucionais internacionais e externos por meio dos quais as assimetrias de relação de troca possam funcionar em favor do poder hegemônico. É por meio desses recursos que, na prática, se extrai um tributo do resto do mundo" - HARVEY, O novo imperialismo, p. 147. As finanças, como se sabe, são um instrumento importante para a extração desses tributos.

${ }^{462}$ HARVEY, O novo imperialismo, p. 128.

463 Termos do autor. Cf. Ibidem, cap. 2.

${ }^{464}$ Harvey menciona uma inflexão no imperialismo estadunidense a partir da primeira eleição de George W. Bush. Tratar-se-ia de uma modalidade "neoconservadora" de imperialismo, como se viu anteriormente, mas que 
processos moleculares de acumulação - por intermédio, sobretudo, de seus mecanismos financeiros:

A economia global do capitalismo sofreu uma radical reconfiguração para reagir à crise de sobreacumulação de 1973-1975. Os fluxos financeiros tornaram-se os meios primários de articulação da lógica capitalista do poder. Mas, uma vez aberta a caixa de Pandora do capital financeiro, incrementou-se igualmente a pressão por transformações adaptativas nos aparelhos de Estado. (...) Disso resultou a ascensão de formas distintivamente neoliberais de imperialismo. A acumulação por espoliação ressurgiu de sua posição secundária anterior a 1970 e veio a ser um aspecto maior da lógica capitalista. ${ }^{465}$

não romperia com os pressupostos econômicos do neoliberalismo e se aprofundaria no recurso à acumulação por espoliação.

${ }^{465}$ HARVEY, O novo imperialismo, p. 150. 


\section{CAPÍTULO 7 - A TEORIA DAS FINANÇAS}

É indispensável comentar ainda outro texto de Harvey, Limits to Capital. Escrito muitos anos antes dos demais livros aqui tratados, ele constitui-se num balanço da teoria "madura" de Marx sobre os fundamentos do capitalismo. Harvey empreende um esforço de compreensão aprofundada de $O$ Capital, exaltando sua importância, ao mesmo tempo que expõe algumas críticas e tenta preencher certas lacunas. Limits to Capital contém a primeira formulação de muitas das idéias ou conceitos que aparecem em textos posteriores. Ele foi uma espécie de base teórica que permitiu ao autor prosseguir suas investigações sobre o capitalismo contemporâneo, inclusive no que se refere ao seu aspecto financeiro, como fica evidente na seguinte passagem redigida para a introdução da nova edição de 2006 :

[Em Limits to Capital,] eu havia construído, como se verificou posteriormente, um fundamento teórico robusto para se explorar criticamente em que poderia se constituir o processo de globalização dominado pela finança [finance-led process of globalization]. Limits era - e continua a ser - o único texto que eu conheço que procura integrar os aspectos financeiro (temporal) e geográfico (global e espacial) da acumulação no âmbito do quadro geral da argumentação de Marx, em um viés holista e dialético ao invés de segmentado e analítico. ${ }^{466}$

No livro, Harvey analisa, mais de perto do que em qualquer outro lugar, embora de modo mais abstrato, a questão do dinheiro, o funcionamento e a importância do sistema de crédito, o conceito de capital financeiro, etc.

Convém começar pela questão da lei da queda da taxa de lucro (LQTL) e a sua relação com a sobreacumulação de capital, já que esta é - não só para Harvey, mas para Chesnais e outros autores marxistas - um dos fatores mais importantes que levou à financeirização. A LQTL representa o que Harvey chamou de "primeiro corte" na teoria das crises de Marx. Isso porque os fatores que a engendram - principalmente a mudança tecnológica e outros meios de se elevar a produtividade do trabalho, que normalmente dispensam força de trabalho e levam,

\footnotetext{
${ }^{466}$ HARVEY, Limits to Capital, (Introduction to the 2006 Verso edition), p.X.
} 
portanto, à elevação da composição orgânica do capital - são os mesmos que produzem situações de excesso de capital e de força de trabalho. O aumento da massa de capital e de lucro, contraditoriamente acompanhado da queda na taxa de lucro, leva progressivamente à diminuição das possibilidades de valorização do capital. Nesse sentido, a LQTL representa o mecanismo básico que está na origem das crises de sobreacumulação:

$\mathrm{O}$ argumento de Marx da taxa decrescente de lucro demonstra convincentemente que a paixão necessária dos capitalistas pela mudança tecnológica que produz maisvalia, quando associada ao imperativo social da 'acumulação pela acumulação', produz um excedente de capital em relação às oportunidades de emprego para ele. Tal estado de produção excessiva de capital é chamado 'sobreacumulação de capital'. ${ }^{467}$

A LQTL gerou muitos questionamentos, sobretudo no sentido de que não se confirmaria empiricamente de modo inequívoco. Nesse sentido, Harvey argumenta que o mais importante na LQTL é o princípio que lhe é subjacente. Marx, absorvido na sua polêmica com os economistas burgueses, teria feito uma confusão entre o que é essencial e o que é secundário. Ao colocar a LQTL como a grande questão, Marx acabaria contrariando sua própria argumentação ao privilegiar esse fenômeno mais restrito em detrimento daquilo que o fundamenta: "a contradição entre a evolução das forças produtivas, por um lado, e as relações sociais nas quais a produção capitalista se baseia, por outro" ${ }^{\text {468 }}$. Isso significa que a sobreacumulação de capital é um processo ligado à dinâmica mais básica do capitalismo e por isso não pode ser eliminada.

Marx hesitaria também quanto ao estatuto epistemológico da LQTL, tratando-a ora como "lei", ora como "tendência", ou ainda como "lei tendencial". Um dos motivos para isso deve-se ao fato de que Marx formula a LQTL com base no valor e não nos preços (o aumento da composição orgânica do capital leva em conta o valor contido no capital constante e no capital variável), de modo que ela não pode ser adequadamente empregada para descrever a aparência superficial do capitalismo ${ }^{469}$. Ademais, Marx considera o "lucro" decrescente como a mais-valia integral, antes de ser repartida em renda da terra, impostos, juros, etc., o que

${ }^{467}$ HARVEY, Limits to Capital, p. 192.

${ }^{468}$ Ibidem, p. 180.

${ }^{469}$ À luz de Grespan (Cf. GRESPAN, O negativo do Capital), pode-se também interpretar essa dificuldade em definir a queda da taxa de lucro em termos de "lei" ou de "tendência" ao fato de que a crise é uma "necessidade relativa" e não absoluta. Não se pode falar em "lei", pois para isso seria necessário provar que a taxa de lucro deve necessariamente cair, o que não é possível fazer. Por outro lado, "tendência" talvez seja uma definição muito leve para um processo que deve ocorrer necessariamente (ainda que de modo relativo e não absoluto) devido ao próprio funcionamento do capitalismo. 
significa que, empiricamente, a queda do lucro "industrial" pode se dever simplesmente a uma mudança nessa distribuição.

Essa última observação é especialmente importante, pois auxilia na compreensão do fato de que a atual "atonia" da produção de que fala Chesnais não é causada necessariamente por uma queda efetiva da taxa de lucro, mas pelo fato de a finança se apropriar de frações maiores da mais-valia sob a forma de juros/dividendos. A extração de mais-valia até pode aumentar, mas o que permanece como "lucro" a ser reinvestido pode decrescer em termos proporcionais.

Quanto ao estado de sobreacumulação de capital propriamente dito, ele pode, diz Harvey, se apresentar de diferentes modos, ou seja, em diversos tipos de capital "estancado" (que não está circulando e se valorizando). São então comentadas seis formas de manifestação assumidas pela sobreacumulação. Primeiramente, há a famosa superprodução de mercadorias, ou seja, um excesso de mercadorias produzidas e em estoque que encontram dificuldade de serem vendidas no mercado. Pode haver também excesso de estoque de capital constante e de mercadorias ainda não terminadas em relação ao que é necessário para a circulação adequada do capital. Em terceiro lugar, pode existir capacidade produtiva ociosa, sobretudo capital fixo que não é usado em sua plena potencialidade. O capital excedente pode estar ainda na forma monetária - como dinheiro de caixa além da reserva necessária, por exemplo. De forma mais geral, a sobreacumulação pode se manifestar em taxas de retorno decrescentes do capital adiantado (juro, renda, lucro, etc.). Por fim, há ainda os excedentes de "capital variável”, ou seja, de força de trabalho. Baixos níveis de emprego da força de trabalho levam a um aumento além do "necessário" do exército industrial de reserva ${ }^{470}$.

Assim, conclui Harvey:

Essa lista resume as 'formas aparentes' da sobreacumulação e conecta todas elas à contradição fundamental que lhe é subjacente entre a evolução das forças produtivas e a barreira posta pelas relações sociais do capitalismo (...). A análise também nos ajuda a lidar com a controvérsia, sempre ruidosa e obstinadamente equivocada [wrong-headed], presente nos círculos marxistas de se as crises devem

\footnotetext{
${ }^{470}$ Consequentemente, há uma elevação da taxa de exploração - o que significa desvalorização temporária da própria força de trabalho. Fica claro, assim, que essa forma de manifestação da sobreacumulação difere das demais e é objeto importante da luta de classes. Sobretudo em momentos de crise, quando desvalorizações são necessárias para se retomar a acumulação, capitalistas tentam evitar a desvalorização de seu capital constante empurrando-a para a força de trabalho.
} 
ser interpretadas como decorrência do 'subconsumo' (...) ou da tendência à queda da taxa de lucro. ${ }^{471}$

Uma vez instaurada a sobreacumulação, qualquer que seja sua forma, surge sua outra face - a desvalorização, a eliminação de capital -, sem a qual o capitalismo não consegue retomar o equilíbrio da acumulação. Se a sobreacumulação assume diversas aparências, é natural que a desvalorização também o faça. Cada modo de manifestação da primeira pode levar a uma modalidade diferente da segunda, já que, "uma definição puramente técnica de desvalorização (...) [é a de] valor que está 'em repouso' em qualquer estágio particular por mais de um momento",472.

Nesse sentido, nem sempre a desvalorização é absoluta - tal como a destruição física de ativos -, mas relativa. Valores de uso que tenham sido preservados podem retomar seu valor tão logo o processo de rotação do capital siga adiante. Por isso é importante a noção de "tempo de rotação socialmente necessário", já que a desvalorização pode ser concebida como um retardamento da rotação e não só seu estancamento total ou a perda efetiva de ativos.

A centralização do capital está muitas vezes relacionada a processos de desvalorização, sendo muitas vezes um meio para se obter a necessária redução de capital em excesso. São os capitalistas expropriados que pagam a conta, ao transferirem o seu capital aos capitalistas maiores por um valor reduzido. Por isso também as crises são geralmente acompanhadas de grande centralização do capital

É o que ocorre com determinados processos de acumulação por espoliação. Esta é uma estratégia para contornar a sobreacumulação do capital e um de seus mecanismos mais atuais se constitui na orquestração de crises financeiras (ou no aproveitamento das que eventualmente surjam) visando desvalorizar os ativos de dada economia a fim de apropriar-se deles a baixos custos e ganhar com sua "re"-valorização. Esse processo parece ser tanto mais eficaz quanto mais a crise seja "especulativa” e se restrinja aos mercados financeiros - ou seja, afetando o preço dos papéis, mas não tanto os circuitos de valorização produtiva - já que é o capital fictício (duplicata do capital real) que é atingido de cheio e não os ativos físicos. Tão logo a crise seja debelada, os papéis voltam a subir e ganhos são auferidos por uma espécie de especulação "super bem sucedida".

\footnotetext{
${ }^{471}$ HARVEY, Limits to Capital, p. 195.

${ }^{472}$ Ibidem, p. 194 (itálico nosso).
} 
Harvey ainda faz uma interessante observação sobre a desvalorização em um contexto que interessa aqui. Segundo ele, a difusão das sociedades por ações e o advento do "capitalismo financeiro" [finance capitalism] ${ }^{473}$ podem ser interpretados como um "ajuste organizacional e estrutural" ${ }^{\text {"74 }}$ que contrabalança a sobreacumulação. Isso porque parte cada vez maior do capital social total passaria a circular a fim de obter juros/dividendos e não a totalidade da mais-valia. Nesse sentido, o capital em circulação estaria relativamente desvalorizado, pois é remunerado a uma taxa necessariamente menor do que a taxa média de lucro.

O que se deve observar a respeito dessa idéia é que, quando do advento das sociedades por ações, esse capital portador de juros talvez até se "contentasse" com uma parcela da maisvalia ao invés de sua integralidade. No atual período de financeirização, todavia, ele está em melhores condições para exigir seja uma parcela maior dessa mais-valia (aproximando o juro do lucro), seja um aumento da própria taxa desta - que, por conseqüência, aumenta a taxa de retorno do capital portador de juros.

Durante as crises, em que a desvalorização pode de fato adquirir o aspecto de destruição, ficam mais claros os antagonismos latentes entre capitalistas individuais buscando seu próprio benefício e o interesse da classe capitalista. Duas questões levantadas anteriormente voltam então à tona. A primeira, que continua sem poder ser respondida adequadamente, já que demanda um esforço empírico de investigação, é a de como se articulam as diferentes facções da burguesia, se há, ou há ainda, rivalidades entre uma burguesia industrial e uma burguesia financeira e como elas se manifestam. A segunda é a das estratégias que os capitalistas, individualmente ou como classe, utilizam para transferir os custos de desvalorização para outros. Isso é, como se viu, particularmente importante no âmbito do imperialismo, em que países mais poderosos usam os mais fracos para evitar ajustes internos e em que a acumulação por espoliação é usada como instrumento para abrir novos caminhos para o capital.

Por fim, Harvey ainda analisa a inflação como mecanismo de desvalorização. Ela significa, na realidade, a depreciação do dinheiro, de modo que, como salienta o autor, se a desvalorização em geral se inicia como um assunto privado e se estende para a sociedade, a

${ }^{473}$ HARVEY, Limits to Capital, p. 198 (o termo está entre aspas e vem acompanhado apenas da seguinte precisão entre parênteses: "que pode desenvolver práticas tais como aluguel de equipamento financiado pelo banco, etc.", de modo que não se sabe se Harvey está aludindo a um período que tem início no século XIX - ele cita Marx e seu exemplo das ferrovias no parágrafo - ou a um período mais recente do capitalismo).

${ }^{474}$ Ibidem, p. 198. 
inflação é um assunto social com impactos privados. Assim, a transformação da primeira na segunda possui conseqüências importantes. Entre elas, a de que a inflação, representando a socialização da desvalorização, reduz o impacto de eventos particulares no ciclo da acumulação, ao mesmo tempo que os efeitos da sobreacumulação são diluídos entre todas as classes - embora afetem diferentemente cada uma ${ }^{475}$. A inflação auxilia ainda os capitalistas a transferir a desvalorização de seu capital para os trabalhadores de modo mais velado e sem necessitar do aumento do exército industrial de reserva: conferem-se aumentos nominais de salários, mas não reais, aumentando o grau de exploração.

Ainda assim, a inflação não pode eliminar a tendência à sobreacumulação, apenas retardar seus impactos, pois somente a desvalorização das mercadorias (e aí se inclui a força de trabalho) pode permitir a reestruturação e a racionalização necessárias à retomada do equilíbrio da acumulação. Na verdade, a inflação aumenta o problema, na medida em que:

O peso morto do capital fictício improdutivo é cada vez mais percebido, a posição do banco central em relação ao intercâmbio com o exterior se enfraquece progressivamente (...), as estruturas de preços tornam-se tão instáveis que perdem sua coerência como poder de coordenação. ${ }^{476}$

É preciso agora analisar as condições que permitem o surgimento da financeirização. Pode-se dizer que a manifestação mais elementar da possibilidade real de uma discrepância entre valores efetivamente produzidos e os "valores" circulados pelo dinheiro, ou seja, de criação de capital fictício, é a determinação do dinheiro como meio de pagamento e a constituição de um sistema de crédito assim possibilitada. Sem esse fator não é possível circular um valor maior do que a das mercadorias já efetivamente produzidas, uma vez que a operação de compra/venda e a circulação do dinheiro ocorrem simultaneamente. Nesse sentido, o sistema de crédito é a "base" do processo de desenvolvimento dos mercados e operações financeiras e, portanto, da financeirização. Não é sem razão, pois, que Harvey

\footnotetext{
475 Assim, esse mecanismo se assemelha ao da securitização e dos socorros governamentais a empresas e instituições em dificuldades, ao transferir os prejuízos de uns para outros.

${ }^{476}$ HARVEY, Limits to Capital, p. 314.
} 
agrupa a discussão sobre "dinheiro, crédito e finança" em um único capítulo de Limits to Capital $^{477}$.

Nesse capítulo - embora Marx tenha desenvolvido apenas alguns aspectos de uma teoria sobre os fenômenos monetários e financeiros, ou talvez exatamente por isso -, Harvey se vê às voltas com as intrincadas questões aí presentes. De forma geral, o sistema de crédito é, segundo o autor, "um produto dos próprios esforços do capital para lidar com as contradições internas do capitalismo. O que Marx nos mostra é como essa solução do capital acaba por aumentar e não diminuir as contradições" ${ }^{478}$.

Uma dessas contradições consiste no próprio caráter do capital fixo. Do ponto de vista da produção, o aumento progressivo e relativo da parcela de capital fixo no capital total (aumento da composição orgânica do capital) é sinônimo de êxito no incremento da produtividade e de triunfo do trabalho morto sobre o vivo. Essa é, assim, a tendência geral do capitalismo, como indica a lei da queda da taxa de lucro. No entanto, pelo lado da circulação e da mobilidade de capital, o mesmo processo se constitui em uma barreira, já que o capital fica cada vez mais "fixado" em um valor de uso específico e perde "liquidez". Só depois de muitas rotações é que a totalidade do valor contido no capital fixo reassumirá sua forma em dinheiro, retomando a "liberdade" de investimento.

Segundo Harvey, há dois caminhos para resolver essa contradição. Diretamente pela força da ação de uma crise - provavelmente desvalorizando ativos e obrigando a uma mudança na organização produtiva, inclusive renovando o capital fixo -, ou transpondo a contradição para níveis mais elevados, criando condições para crises de outro tipo e geralmente mais profundas. Fica evidente que a capacidade de transposição para níveis mais elevados está intimamente associada ao desenvolvimento de um sistema de crédito cada vez mais complexo. Nesse sentido, Harvey pretende mostrar que o capital portador de juros "é um aspecto socialmente necessário do modo de produção capitalista"479 e que a criação de capital fictício deriva da necessidade do capital de reaver sua mobilidade e flexibilidade de acumulação, bem como, deve-se acrescentar, de multiplicar suas possibilidades de valorização.

Desse modo, o aumento da parcela de capital fixo em relação ao circulante, tempos de rotação relativamente grandes, entre outros fatores, fazem com que haja necessidade de

\footnotetext{
${ }^{477}$ Cf. HARVEY, Limits to Capital, cap. 9.

${ }^{478}$ Ibidem, p. 239.

${ }^{479}$ Ibidem, p. 240.
} 
adiantamentos em dinheiro cada vez mais elevados. Daí a necessidade de um sistema de crédito desenvolvido. $\mathrm{O}$ crédito não só propicia investimentos que não seriam possíveis, pois o produtor capitalista muitas vezes não possui em mãos dinheiro suficiente, como evita o entesouramento infrutífero, ao possibilitar que cada soma de dinheiro, por menor que seja, possa ser imediatamente transformada em capital por intermédio de bancos e instituições financeiras.

Harvey argumenta, assim, que um sistema de crédito cada vez mais desenvolvido torna-se um imperativo da lógica "capitalista" e obriga os capitalistas a criarem continuamente novos e sofisticados instrumentos financeiros, de modo que o capital portador de juros adquire um papel especial na circulação do capital, portanto também na acumulação em geral.

Contudo, uma ponderação deve ser feita quanto a esse processo. Embora haja uma tendência na lógica do capital que exige o desenvolvimento do sistema de crédito (e de produtos e mercados financeiros), não se deve descartar a hipótese de que determinadas situações econômicas ou fases históricas do capitalismo o estimulem em maior grau que outras. Esse parece o caso do capitalismo pós-1970, em relação ao período fordista, devido a fatores econômicos, políticos e institucionais. Por outro lado, isso sugere também que uma "desfinanceirização" da economia mundial, em marcos capitalistas ou sem enormes lutas políticas, é pouco provável. Se o setor financeiro se desenvolveu a tal ponto, mesmo que de modo especulativo, foi para atender a certa dinâmica do capitalismo, principalmente à resolução da crise de sobreacumulação dos anos 70 sem passar por grandes desvalorizações de capital. Desfazer-se de todo esse aparato institucional, com o rearranjo político que isso implica, e empreender as desvalorizações necessárias parece hoje como algo fora do horizonte do capitalismo.

O incremento do sistema de crédito, por outro lado, não é um processo que ocorre sem problemas e contradições:

O poder coercitivo da concorrência força os capitalistas, como agentes econômicos individuais, a abusar desse sistema e, portanto, a solapar o poder social do dinheiro (...) Disso resulta que o seu uso do dinheiro como meio de circulação por meio do sistema de crédito solapa a utilidade do dinheiro como medida e reserva de valor. ${ }^{480}$

${ }^{480}$ HARVEY, Limits to Capital, p. 254. 
A discussão do crédito inevitavelmente esbarra, portanto, na questão do dinheiro, sobre a qual Harvey conduz uma série de observações importantes. Primeiro, a contradição inerente ao dinheiro - de, como meio de circulação, estar encarnado em um valor de uso específico, ao passo que deve, como medida de valor, expressar o trabalho abstrato - se intensifica com a introdução do papel-moeda. O que deveria ser uma solução para o problema da moeda atrelada a uma mercadoria (o fato de não ser facilmente ajustável às necessidades da circulação) cria um novo problema, pois abre a possibilidade de uma divergência entre seus valores reais e nominais. A produção de moeda deve, portanto, ser estritamente controlada $^{481}$ e uma legislação se faz necessária. O Estado usualmente toma para si a função de cunhagem, tornando-se assim um importante agente econômico.

Em resposta quase que "espontânea" ao desgaste das moedas e às limitações espaciais e temporais da circulação do dinheiro, surge o dinheiro de crédito (inclusive na forma escritural/contábil). Sua vantagem é ser altamente ajustável às necessidades de circulação e propiciar economias nos custos de transação, ao facilitar o uso do dinheiro como meio de pagamento e não só de circulação. De modo peculiar, afirma Harvey, o dinheiro é social, ainda que utilizado para fins privados, ao passo que o dinheiro de crédito é privado (pois é emitido pelos próprios agentes econômicos privados, sobretudo bancos), porém usado para propósitos sociais. Além disso, enquanto o dinheiro fica permanentemente em circulação, o dinheiro de crédito precisa retornar de alguma forma para seu emissor, saindo então de circulação. Neste caso, quando a dívida não é paga, o dinheiro de crédito é imediatamente desvalorizado, o que é um assunto privado, mas com consequiências sociais que podem ser profundas.

Os bancos, por sua vez, substituem os diferentes dinheiros de crédito pelos seus próprios papéis (ou checam a confiabilidade daqueles) - tomando para si a função de garantidor das operações - e economizam ainda mais nos custos de transação por meio de câmaras de compensação. Eles se tornam, assim, agentes vitais no capitalismo, concentrando grande poder social. O banco central, controlando o dinheiro nacional, situa-se um nível acima nessa hierarquia das instituições monetárias. Por sua vez, somente grandes potências, como os EUA atualmente, podem desempenhar a função de um "banqueiro do mundo"482 e ocupar o topo da hierarquia. Porém, estar nessa posição, argumenta Harvey, embora propicie certos benefícios, traz um dilema, já que a moeda nacional é também mundial: surge a dúvida

\footnotetext{
${ }^{481}$ Pois a inflação se torna uma possibilidade bastante real.

${ }^{482}$ Cf. HARVEY, Limits to Capital, p. 248.
} 
entre defender os interesses do capital nacional ou defender os interesses do capital em âmbito mundial.

A contradição existente entre o dinheiro como medida de valor e como meio de circulação nunca é resolvida, ela é apenas transposta a níveis cada vez mais elevados na hierarquia das instituições financeiras ${ }^{483}$. Além disso, a ação de bancos privados e bancos centrais para controlar a economia ${ }^{484}$ é limitada. Ainda assim, fica clara a base "material" mais elementar de seu poder, que permitiu a eles (e às novas instituições da finança) adquirir amplo poder em determinadas circunstâncias históricas. Em resumo, "o dinheiro existe como encarnação do poder social (...) O capital monetário pode funcionar como o capital comum da classe capitalista, mas também pode ser apropriado e reunido por indivíduos privados" ${ }^{485}$, sendo normalmente centralizado e controlado mais diretamente pelas instituições financeiras.

Isso fica muitas vezes claro na questão da determinação da taxa de juros. Seguindo Marx, Harvey defende que a atividade de emprestar e tomar emprestado estabelece uma relação de classe entre "donos do dinheiro" e "empregadores do capital"486. Os capitalistas monetários, à medida que puderem ditar a taxa de juros e os prazos de pagamento, se colocam no controle direto da intensidade de produção de mais-valia. Harvey parece atribuir esse poder por parte dos capitalistas monetários a momentos pontuais, como em determinadas fases das crises cíclicas, em que o crédito é escasso. Contudo, talvez seja possível relacionar também esse poder a situações perenes ditadas por determinadas configurações políticas e institucionais que beneficiam o capital monetário, como é o caso do capitalismo financeirizado.

Uma vez que o capital portador de juros cria uma cisão entre dois tipos de capitalista, um dos quais, o seu representante, não participa diretamente da produção - mas somente da

\footnotetext{
${ }^{483}$ Segundo Harvey, a contradição atinge seu paroxismo no âmbito mundial, em que, com o dinheiro sem lastro em mercadoria, a questão de sua determinação como medida dos valores permanece sem solução. Cf. HARVEY, Limits to Capital, pp. 249-250.

484 “A situação de monopólio que um banco central ocupa em um país não lhe dá poderes efetivos de controle, não importa quão impressionante sejam os poderes da autoridade monetária. Do mesmo modo, banqueiros privados exercem controle somente após os descontadores individuais não poderem continuar usando suas letras de câmbio privadas" - Ibidem, p. 250.

485 Ibidem, p. 241.

${ }^{486}$ Cf. Ibidem, p. 256.
} 
absorção - da mais-valia, surge a questão de por que o capitalista monetário é "tolerado". Em parte, diz Harvey, precisamente porque o capital portador de juros cumpre certas funções vitais para a acumulação do capital, o que implica a constituição de um poder externo ao processo de produção. Além disso, a própria circulação de capital confere um papel especial para o dinheiro como equivalente geral, o que, como se viu, fornece o suporte necessário para uma classe de capitalistas monetários. Ou seja, em certa medida o capital portador de juros não é tolerado, mas se impõe ao funcionamento do capitalismo como uma necessidade, ao mesmo tempo que institui atores sociais que trabalham pela sua expansão. Por isso, é importante passarmos rapidamente em revista as funções e os canais institucionais do sistema de crédito que Harvey analisa ${ }^{487}$, por meio dos quais o capital portador de juros opera.

A primeira função do sistema de crédito é a "mobilização do dinheiro como capital", ou seja, permitir que o dinheiro, mesmo em pequenas somas, possa funcionar como capital portador de juros. Isso é feito através da centralização operada por bancos e outras instituições financeiras. Como observa Chesnais, o excedente e poupança de todas as classes são reunidas e "homogeneizadas" sob este processo, de modo que os indivíduos perdem sua identidade social e se tornam todos "poupadores", gerando confusões e contradições. No caso dos trabalhadores, eles parecem se transformar em capitalistas monetários - uma flagrante contradição - já que passam a ter direito sobre parte da mais-valia que produzem. Além disso, observa Harvey, "os trabalhadores possuem grande interesse na preservação desse mesmo sistema que os explora, pois a destruição deste resulta na destruição de sua poupança",488, situação esta que talvez constitua um dos qüiproquós mais importantes do capitalismo financeirizado em termos político-ideológicos.

Outra função do sistema de crédito é a redução do tempo e dos custos de circulação monetária, tornando-a mais eficiente e econômica. Isso é importante, pois diminui as barreiras temporais e espaciais à circulação e faz com que compras e vendas se distanciem cada vez mais. Nesse sentido, na mesma proporção que o sistema de crédito generaliza, amplia e desenvolve as funções do dinheiro e as possibilidades de acumulação, ele reforça sua tendência de gerar crises ${ }^{489}$.

\footnotetext{
${ }^{487}$ Para mais detalhes, ver HARVEY, Limits to Capital, cap. 9, itens IV e V.

${ }^{488}$ Ibidem, p. 263.

${ }^{489}$ Isso é confirmado pela situação atual: o alto grau de desenvolvimento do sistema de crédito e dos mercados financeiros existente é acompanhado de crises cada vez mais recorrentes e intensas.
} 
Duas outras funções, interligadas entre si, são a criação de capital fictício e a circulação do capital fixo ${ }^{490}$. O sistema de crédito propicia investimentos maiores em capital fixo ${ }^{491}$ assim como permite que o dinheiro nele aplicado, à medida que é recuperado ao longo do tempo, seja investido como capital até ser usado para sua renovação ou manutenção. As operações para facilitar a circulação do capital fixo estão intimamente associadas à formação de capital fictício, já que pressupõem a geração futura de valor:

A categoria de 'capital fictício' está de fato implicada onde quer que o crédito seja concedido como antecipação de um trabalho futuro como contra-valor. Esse tipo de capital permite uma permuta suave entre capital circulante sobreacumulado e formação de capital fixo - um processo que pode disfarçar inteiramente o aparecimento de crises no curto prazo. ${ }^{492}$

O capital fictício, cujo surgimento é derivado do capital portador de juros e possibilitado pela própria forma dinheiro (especialmente pelo dinheiro de crédito), constituise no instrumento que permite aos capitalistas monetários não "empatar" o seu capital em um empreendimento qualquer pelo tempo necessário de retorno do empréstimo ${ }^{493}$. Ele está contido no próprio conceito de capital e permite sobrepujar essas barreiras colocadas pelo capital fixo. A criação acidental de capital fictício, portanto, se torna uma necessidade tão logo se conecte o processo de circulação do capital portador de juros e do capital fixo, pois as diferentes estratégias para evitar a imobilização do capital monetário na produção se baseiam no capital fictício. Contudo, o capital portador de juros é contraditório: dinamiza o processo de acumulação reduzindo os entraves a ele ao preço de dar origem às formas fictícias de capital, que ampliam a ocorrência de crises.

Diferentemente do crédito comercial mais simples (um "valor fictício"494), o capital monetário não é adiantado contra uma mercadoria que ainda não se vendeu, mas contra trabalho futuro, ou seja, mais-valia futura, o que é ainda mais incerto. O título representado pelo capital fictício é uma duplicata do capital real e, por isso, não pode ser reavido. Eles circulam em um espaço próprio, de modo que, embora possam refletir mudanças relacionadas ao capital fixo, "os preços desses títulos podem, então, flutuar de acordo com suas próprias

\footnotetext{
${ }^{490}$ Mas também a formação de fundos de consumo, ao facilitar a aquisição de mercadorias mais caras e de vida útil mais longa.

${ }^{491}$ Essa é, inclusive, uma estratégia essencial dos deslocamentos temporais.

${ }^{492}$ HARVEY, Limits to Capital, p. 266.

${ }^{493}$ Viu-se o papel que os mercados financeiros tiveram em conferir liquidez aos investimentos.

${ }^{494}$ Ibidem, p. 267.
} 
regras 'de modo inteiramente independente do movimento de valor do capital real",495, o que está em estreita concordância com as idéias de Chesnais.

O sistema de crédito é ainda fundamental para a equalização da taxa de lucro. O livre fluxo do capital portador de juros diminui os entraves à equalização na medida em que facilita o direcionamento do capital para os setores com maiores taxas de lucro. Harvey define o sistema de crédito como uma "espécie de sistema nervoso central para a coordenação das atividades divergentes dos capitalistas individuais" ${ }^{\prime 496}$. Esse é mais um fator que explica a emergência do capital portador de juros. Por outro lado, ele engendra novas contradições na medida em que o capital comum da classe capitalista é mobilizado pelos capitalistas monetários segundo seus próprios interesses - que nem sempre coincidem com os da classe.

Por fim, a última função do sistema de crédito apresentada por Harvey é a de facilitar a centralização do capital. Sem mencionar os processos eminentemente financeiros de centralização que ocorrem no interior das Bolsas, pode-se afirmar que, além de financiar a expansão do capital fixo, o crédito auxilia na sua renovação e na reestruturação produtiva. Os capitalistas em melhores condições de crescer e de empreender mudanças organizacionais e tecnológicas aumentam sua taxa de lucro e se posicionam melhor na concorrência, podendo, assim, "engolir" mais facilmente os capitalistas menores. Mas o sistema de crédito é também uma exigência da centralização, já que quanto maior o capital, maior a necessidade de crédito.

Harvey reconhece que o sistema de crédito necessita de pessoas e instituições que o façam funcionar, apontando assim uma dimensão político-institucional da questão. Para ele, banqueiros, financistas, operadores da bolsa, etc. formam em algum grau uma "classe especial dentro da burguesia (...) [que] ocupa o que parece ser o alto comando da economia” ${ }^{, 497}$, devido ao papel do sistema de crédito como "sistema nervoso central" do movimento do capital. Harvey não pretende, contudo, fazer uma análise exaustiva dos inúmeros arranjos institucionais existentes, mas criar uma base teórica para compreendê-los.

${ }^{495}$ HARVEY, Limits to Capital, p. 268 (o trecho entre aspas é de O Capital, de Marx [livro III, vol. 5, p. 20 da edição brasileira]).

${ }^{496}$ Ibidem, p. 270.

${ }^{497}$ Ibidem, p. 272. 
Em primeiro lugar, o autor faz uma distinção entre circulação dos rendimentos ${ }^{498}$ e a circulação do capital. Há dois pontos importantes a esse respeito. Por um lado, é enfatizado que a circulação do dinheiro como rendimento é um processo muito diferente da circulação do dinheiro como capital. Segundo o exemplo fornecido, uma cooperativa de trabalhadores que financia a habitação para seus membros cobrando juros está formalmente, mas não realmente, submetida ao domínio do capital portador de juros: "o que ocorre aqui é apenas que o rendimento dos trabalhadores (capital variável) está sendo redistribuído no interior da classe trabalhadora, de famílias com excedentes para famílias precisando se endividar para adquirir as casas de que precisam" ${ }^{, 499}$. Esse paralelo com a subordinação formal/real do trabalho ao capital no nível da produção é muito interessante, pois mostra que a forma juro não possui as mesmas determinações e, portanto, não significam a mesma coisa em toda parte e em qualquer situação - embora de todo modo haja alguma submissão ao capital e à sua lógica.

Isso leva ao segundo ponto da questão. Via sistema de crédito, inúmeras transações se tornam uma relação entre devedor e credor, de modo que se podem conceber vários "minicircuitos" ${ }^{, 500}$ no interior do sistema de crédito. Em muitos desses, como mostra o exemplo acima, os juros não são uma fração direta da mais-valia. O problema é que o sistema de crédito tende a mesclar esses diferentes circuitos - misturando os dois tipos de circulação e conectando trabalhadores, burgueses, governos - obscurecendo, assim, os processos em jogo. De todo modo, fica claro que a estrutura financeira é em alguma medida fragmentada, o que implica a existências de vários mercados financeiros. Contudo, isso não significa que essa estrutura não seja integrada - e a tecnologia tem aí um papel importante.

As sociedades por ações e os mercados para o capital fictício constituem o segundo item discutido sobre a questão institucional. O mercado de ações é um mercado de capital fictício destinado a fazer circular direitos de propriedade. Cada tipo de título pode exigir um modo diferente de circulação, donde a criação de instituições especializadas. Em acordo com o que afirmam Carcanholo e Sabadini ${ }^{501}$, Harvey defende que o preço das ações é definido pelo princípio da capitalização (são capital fictício), porém, dado que as sociedades anônimas realmente existem, há uma capacidade real de produção de mais-valia. Contudo, diferentemente das teorias que pressupõem a transparência e simetria de informações, argumenta-se que só se pode saber a efetiva situação da empresa tendo acesso a seus

\footnotetext{
498 "Revenues", no original, diferentemente de "renda" no sentido de "rent".

${ }^{499}$ HARVEY, Limits to Capital, p. 274.

${ }^{500}$ Ibidem, p. 274.

${ }^{501}$ Cf. CARCANHOLO e SABADINI, "Capital fictício e lucros fictícios".
} 
balanços, o que abre espaço para a especulação. Enfim, os mercados de capital fictício são, segundo Harvey, "vitais para a sobrevivência do capitalismo, pois somente através deles é que a continuidade do fluxo do capital portador de juros pode ser assegurada (...) Os mercados de capital fictício fornecem modos para se coordenar a força coordenadora na sociedade capitalista" ${ }^{, 502}$.

O terceiro item trata do sistema bancário, embora não detalhadamente. Uma distinção inicial é entre bancos e demais instituições financeiras. Isso porque estas apenas podem mobilizar somas já produzidas - que lhe são confiadas pelos investidores. Já os bancos têm a capacidade de "criar" crédito, ou seja, de criar capital monetário antes da produção, colocando em circulação valores monetários fictícios, ao substituir as letras de câmbio que os capitalistas circulam entre si por seus próprios papéis. Assim, eles podem converter um fluxo de dinheiro usado como meio de pagamento em capital monetário disponível. A princípio, sua única limitação é a reserva em dinheiro necessária para cobrir os saques.

Essa capacidade dos bancos é, segundo Harvey, fundamental na medida em que, com o declínio da acumulação primitiva, os bancos se tornaram a principal fonte de provimento de recursos disponíveis para forçar as realocações dos fluxos de capital para usos mais produtivos. Mesmo em relação à outra fonte possível - a sobreacumulação do capital - a capacidade produtiva ociosa ou as mercadorias excedentes precisam passar para a forma monetária por intermédio dos bancos antes de serem realocadas.

Com isso, fica mais claro o papel fundamental que os circuitos financeiros possuem nos deslocamentos espaciais e temporais como estratégia para dar destinos lucrativos ao capital. Mesmo com o retorno da acumulação por espoliação e seus métodos "primitivos", a importância do capital financeiro não se reduz, pois muitos dos mecanismos espoliativos centrais hoje passam pelas finanças.

Sendo o capital bancário, portanto, em grande parte fictício e tendo a criação de valores fictícios se tornado não só uma "tentação", mas uma necessidade, a potencialidade de uma "super-especulação" [over-speculation $]^{503}$ é enorme ${ }^{504}$. A especulação coloca em risco a qualidade do dinheiro, gerando problemas para a economia. Segundo Marx, o banco central é a pedra angular do sistema de crédito, assim como a reserva metálica é a garantia dos bancos.

\footnotetext{
${ }^{502}$ HARVEY, Limits to Capital, p. 278.

${ }^{503}$ Ibidem, p. 280.

${ }^{504}$ É precisamente esse o caso dos mercados financeiros atualmente, haja vista as origens da crise financeira de 2008.
} 
Sem o lastro, o banco central deve regular o fluxo de crédito para garantir a qualidade do dinheiro, criando, pois, uma contradição entre fomentar a acumulação via crédito e preservar o dinheiro.

Isso desemboca no quarto e último item abordado por Harvey - o Estado - já que:

$$
\begin{aligned}
& \text { O que de fato ocorre é o seguinte: o sistema de crédito proporciona um meio para } \\
& \text { disciplinar os capitalistas individuais, e mesmo frações inteiras do capital, às } \\
& \text { exigências de classe. Mas alguém tem que regular os reguladores. O banco central } \\
& \text { se esforça para preencher essa função, mas, na medida em que os poderes } \\
& \text { reguladores estão nas mãos de uma fração específica do capital, eles estão } \\
& \text { praticamente condenados a serem pervertidos e solapados. }{ }^{505}
\end{aligned}
$$

Na realidade, como o próprio Harvey admite, o Estado não é objeto de considerações aprofundadas em Limits to Capital. Basicamente, a competição acirrada entre os capitalistas monetários impede que eles próprios se regulem, levando à necessidade da intervenção do Estado. Assim, o banco central não seria somente o pivô do sistema de crédito, mas também um controle essencial por parte do aparato estatal. Porém, a ação deste vai além do banco central, sendo o sistema de crédito um campo mais amplo de intervenção das políticas do Estado e alvo de disputas. É no posfácio do livro que Harvey fornece mais algumas indicações sobre a questão do Estado que, no fim, mostram que este "possui um papel vital em quase todos os aspectos da reprodução do capital"506.

$$
* * *
$$

Após a discussão mais geral sobre dinheiro, crédito e finança, Harvey dedica um capítulo de Limits to Capital para a análise específica do capital financeiro. É preciso lembrar já de início, como o próprio autor faz, que Marx não usou o termo "capital financeiro", tendo sido este empregado posteriormente por autores como Hilferding e Lênin.

O que Marx deixou foram escritos sobre a circulação do capital monetário (incluindose aí o capital portador de juros e capital fictício). Nesse sentido, na definição de "capital financeiro" estaria implícito, segundo Harvey, um tipo particular de circulação do capital monetário centrado no sistema de crédito. Por outro lado, Hilferding e Lênin tenderam a

\footnotetext{
${ }^{505}$ HARVEY, Limits to Capital, p. 281.

${ }^{506}$ Ibidem, p. 449.
} 
enfatizar a dimensão do capital financeiro como formação de blocos de poder no interior da burguesia que passam a exercer grande influência sobre a acumulação do capital. Esse conceito mais político não deixa de se apoiar no próprio Marx - que indica que o surgimento do capital portador de juros cria uma cisão na burguesia e opõe capitalista monetário e capitalista industrial. Há também pretensões mais "empíricas" - de compreender uma situação concreta no caso de Hilferding, sobretudo da Alemanha.

Entre essas duas concepções de capital financeiro, Harvey não descarta a segunda, mas a critica, dando mais ênfase, assim, à primeira ${ }^{507}$. Seu argumento inicial é de que:

A exploração da primeira [visão do capital financeiro como um processo], com ênfase particular em suas contradições internas, ajuda a identificar as forças de contrapeso que simultaneamente criam e solapam a formação de blocos de poder coerentes no seio da burguesia (...) [Além disso,] a compreensão correta dos processos possui certa prioridade na teoria marxista porque nos proporciona idéias muito mais profundas sobre a dinâmica da acumulação e sobre a formação de crises do que poderia fornecer qualquer sondagem dos intrincados mecanismos da formação de um bloco de poder. ${ }^{508}$

Essa preferência pela compreensão do capital financeiro como um processo de circulação fica clara na exposição de Harvey, que enfatiza a análise do sistema de crédito e do dinheiro $^{509}$. O sistema de crédito confere ao capital portador de juros o poder de coordenação e de otimização da acumulação, o que é possível pelo fato do dinheiro representar o poder social geral. O capital monetário mobilizado pelo sistema de crédito representa, assim, o capital comum da classe capitalista, cuja "vontade" pode ser imposta a capitalistas individuais. As contradições entre os interesses capitalistas individuais e de classe parecem poder ser, então, controladas ou administradas.

Nesse sentido, o sistema de crédito também parece conter, segundo Harvey, o potencial de superar os antagonismos entre produção e consumo, entre produção e realização,

\footnotetext{
507 Essa tendência a encarar o capital financeiro mais como um processo do que como um bloco de poder permanece em textos posteriores. Por exemplo: "Na atual fase, contudo, o que importa não é tanto a concentração de poder em instituições financeiras quanto a explosão de novos instrumentos e mercados financeiros, associada à ascensão de sistemas altamente sofisticados de coordenação financeira em escala global" - HARVEY, Condição pós-moderna, p. 181.

${ }^{508}$ HARVEY, Limits to Capital, pp. 283-284.

509 É digno de nota, contudo, que, em obras posteriores, o componente mais diretamente "político" do capital financeiro ganha importância, como exposto nos outros capítulos da Parte II. Não se trata tanto, é verdade, de blocos de poder que comandam a acumulação, mas ainda assim Harvey menciona atores ligados diretamente ao capital portador de juros agindo com determinados interesses.
} 
sendo indispensável à sobrevivência do capitalismo ${ }^{510}$. Contudo, lembra o autor, "não há substituto para a efetiva transformação da natureza por meio da produção concreta de valores de uso" ${ }^{\text {511 }}$. Crises continuam a ocorrer, pois o crédito somente tem a capacidade de lidar com problemas relativos ao intercambio e à circulação, mas não à produção. Ele apenas transpõe a contradição para um nível mais geral e acaba, em certo sentido, deteriorando a situação: impulsionando a escala de produção e a centralização do capital, acelerando a rotação deste, etc. o sistema de crédito na verdade agrava os processos de formação de crises. A produção de mercadorias só poderia ser submetida ao controle da classe capitalista se o financeiro e o industrial fossem a mesma pessoa (idéia adotada por Hilferding e Lênin, segundo Harvey).

Além disso, são mencionadas circunstâncias em que o crédito criaria sinais equivocados de preços. Dentre elas, figura a questão de "certo poder independente dos financistas" $" 512$ que os destaca como representantes do "capital em geral", ou seja, de indivíduos que conseguem - na verdade, pela concorrência, são impelidos a - utilizar o poder social encarnado no dinheiro para fins privados. Banqueiros e financistas podem, pois, se apropriar de parte da acumulação real às expensas dos capitalistas industriais. Esse mesmo fundamento está por trás da idéia de Chesnais de punção da finança sobre a produção. Não obstante, o argumento de Chesnais recorre de certo modo a uma visão de "bloco de poder" para interpretar a mudança institucional ocorrida na financeirização que operou a internalização da exterioridade da finança em relação à produção. Nesse sentido, a apropriação de valor por parte da finança ocorre também através do controle direto da produção, e não só pela circulação da mais-valia entre capitalista industrial e capitalista monetário "exterior".

Isso leva às considerações de Harvey sobre essa segunda visão sobre o capital financeiro. Segundo Hilferding e Lênin, o capital financeiro seria precisamente a fusão do capital bancário de poucas grandes instituições monopolistas com o capital industrial de empresas também monopolistas. A expansão das atividades desse bloco de poder para além das fronteiras nacionais remete à questão do imperialismo - a sobreacumulação tendo aí um duplo papel. Por um lado, o impulso em direção ao imperialismo e à decorrente exportação de capital tem origem precisamente na formação de capital excedente nos países centrais do

\footnotetext{
${ }^{510}$ Harvey menciona alguns mecanismos que auxiliam o capital, tais como o arrocho salarial através de inflação alimentada pelo crédito; "explorações secundárias", tais como hipotecas, crédito pessoal, etc.; facilitação da centralização do capital - Cf. HARVEY, Limits to Capital, p. 285.

${ }^{511}$ Ibidem, p. 285.

512 Ibidem, p. 286.
} 
capitalismo. Por outro lado, do modo como Harvey resume o argumento de Hilferding, os bancos começam a "fixar" seu capital na indústria devido ao excesso de capital acumulado em suas mãos. Nesse sentido, o movimento de fusão entre capital bancário e industrial pode ser interpretado ele mesmo como resultante de uma espécie de sobreacumulação do capital bancário (monetário) que tenta ser resolvida por meio de um ajuste temporal (investimento em capital fixo) e espacial (exportação de capital).

A especulação com títulos possui um papel de destaque no processo, e a ascensão de uma oligarquia financeira parece alterar a luta de classes. O Estado, por sua vez, não poderia ficar incólume, tornando-se um agente do capital financeiro. A mudança na ação do Estado, aliada à situação de monopolização, levaria a certa transposição de determinadas contradições internas do capitalismo para o âmbito mundial - expressas em um desenvolvimento desigual entre países.

A objeção de Harvey a Hilferding é de que Marx constrói sua teoria do dinheiro a partir da produção e troca de mercadorias - sem referência à circulação do capital -, constatando uma contradição no dinheiro entre medida do valor e meio de circulação, que se acirra quando o dinheiro começa a circular como capital. Já Hilferding quase suprimiria essa contradição, de modo que os fenômenos monetários pareceriam ser totalmente controlados pelo capital financeiro. O autor ainda cita a síntese elaborada por Suzanne de Brunhoff de que Hilferding construiu uma "teoria financeira dos fenômenos monetários", ao passo que Marx havia construído uma "teoria monetária da finança" 513 . Por fim, Hilferding ainda mencionaria a idéia de Marx de que, durante a crise, haveria o retorno à base monetária, mas não deixaria claro como isso ocorre. Isto leva Harvey a tratar da questão da contradição entre o sistema financeiro (crédito) ${ }^{514}$ e sua base monetária.

Nesse sentido, o sistema financeiro possui uma base monetária da qual, em última instância, nunca pode se desprender. Embora essa idéia de Marx tenha sido formulada pressupondo o dinheiro metálico, Harvey ressalta aí um princípio mais geral: a contradição entre o sistema financeiro e sua base monetária remonta à contradição interna do dinheiro entre medida de valor e meio de circulação ${ }^{515}$. Ao funcionar como medida de valor, o dinheiro

\footnotetext{
${ }^{513}$ Cf. HARVEY, Limits to Capital, pp. 291-292.

${ }^{514}$ Harvey parece equiparar "sistema de crédito" e "sistema financeiro", talvez o segundo sendo uma forma mais desenvolvida e específica do primeiro (relativa aos mercados financeiros, em que o capital financeiro opera).

${ }^{515}$ Nesse ponto, Harvey se atém à contradição entre medida de valor e meio de circulação, sem analisar a terceira determinação do dinheiro - de meio de pagamento. Contudo, uma vez que o dinheiro começa a funcionar como
} 
deve ser a expressão do trabalho social e, portanto, representar efetivamente os valores que ele ajuda a circular; no entanto, o dinheiro está corporificado em uma determinada mercadoria, produto de um trabalho concreto.

Assim, quando o dinheiro funciona como meio de circulação, ele se "desprende" dessa representação "verdadeira" do valor, permitindo que os preços se desviem dos valores para facilitar o processo de troca. Donde o surgimento do dinheiro em papel e do dinheiro de crédito. Desse modo, o que Marx chamou de contradição entre o sistema de crédito e sua base monetária decorre, de acordo com Harvey, da exacerbação dos aspectos fictícios do dinheiro, que enfraquece suas ligações com o trabalho social. A dissociação do dinheiro como expressão do trabalho social e sua circulação na esfera financeira é o centro da contradição ${ }^{516}$.

A demanda por "liquidez" decorrente de uma crise implica esse retorno à base monetária, o que exige desvalorização de mercadorias e destruição de capital fictício. Em tempos de dinheiro sem lastro, o banco central pode emitir mais dinheiro inconversível para a compra do excesso de mercadorias ou realização do capital fictício ${ }^{517}$. Mas a impressão de mais dinheiro pode desvalorizá-lo e levar ao aumento da inflação e da ficção ${ }^{518}$, já que se trata, na expressão de Chesnais, de "curar o mal com o mal"519. O dilema é defender o valor do dinheiro em detrimento do valor das mercadorias ou vice-versa, o que de todo modo é irracional. Em resumo, diz Harvey, o que a teoria de Marx defende é que a contradição entre sistema financeiro e a base monetária se expressa na contradição entre capital na forma mercadoria e capital na forma monetária. A sobreacumulação do capital colocaria, assim, a escolha entre inflação ou depressão.

Nesse sentido, o capital financeiro é relativamente impotente para resolver a contradição de modo satisfatório. Esse ponto fundamental teria de certa forma escapado a Hilferding e o levado a super-dimensionar o poder do "bloco" formado pelo capital financeiro. É preciso considerar, assim, a possibilidade dessa observação se aplicar de certa

meio de pagamento e passa também a circular como capital, a criação de capital fictício surge, então, como uma decorrência direta.

${ }^{516}$ Harvey também não se aprofunda muito no problema do dinheiro sem lastro. Limita-se a dizer que ele é transposto para níveis superiores, ficando sem solução no âmbito mundial, enquanto o banco central é que, no nível doméstico, suporta o fardo de disciplinar o sistema de crédito e de manter a qualidade do dinheiro, impedindo que a especulação saia do controle.

${ }^{517}$ Os bilhões de dólares emitidos por governos para socorrer empresas e instituições em apuros mostram até onde isso pode chegar.

518 O dinheiro extra colocado em circulação pode ser usado de diversos modos, inclusive alimentando a circulação de capital fictício e reforçando, pois, a especulação.

${ }^{519}$ CHESNAIS, "La prééminence de la finance (...)", p. 118. 
maneira a Chesnais, que também admite a existência de blocos de poder e a preponderância da fração financeira da burguesia.

Por outro lado, Harvey afirma que a sobrevivência do capitalismo depende de haver certo equilíbrio entre os interesses financeiros e industriais - provavelmente devido ao fato de o capital portador de juros e a esfera financeira serem, em última instância, materialmente dependentes da esfera produtiva. Porém, Chesnais mostra que, exatamente porque tal equilíbrio não pode ser garantido de antemão, no capitalismo financeirizado há uma dominância desmesurada dos interesses financeiros que acaba prejudicando o investimento e a acumulação $^{520}$.

Viu-se que Harvey apresenta duas concepções ligadas ao capital financeiro: uma como determinado processo de circulação do capital portador de juros e outra como um bloco de poder interno à burguesia. Embora ao longo de Limits to Capital o autor se aprofunde mais na primeira e apresente críticas à segunda, afirma que nenhuma das duas em separado é correta, sendo de certo modo necessário reuni-las. Assim, à primeira vista, devido ao seu mistério e complexidade, o poder das instituições e mercados financeiros parece assustador. Contudo, por trás disso haveria uma vulnerabilidade que a visão do capital financeiro como processo ajudaria a revelar. $\mathrm{O}$ autor, portanto, se debruça sobre alguns aspectos da concepção sobre o bloco de poder relativizando-os ou criticando-os a partir das contradições postas pela consideração do processo de circulação.

A questão do capital financeiro como uma classe ou fração de classe, na concepção de Harvey, pode ser resumida na relação entre centralização e descentralização do poder financeiro. Por um lado, é verdade que aqueles que controlam o dinheiro como um poder externo à produção estão numa posição privilegiada (sejam famílias ou instituições), e que isso é alcançado mediante a centralização do capital monetário em poucas mãos. Porém, uma vez que a circulação do capital portador de juros e o sistema de crédito são o poder coordenador na economia capitalista, a extrema centralização do capital monetário entra em

\footnotetext{
${ }^{520}$ Sem mencionar o fato de que o capital financeiro pode elevar seus ganhos sem necessariamente diminuir os do capital industrial, através de uma exploração mais elevada do trabalho, cujo diferencial é integral ou majoritariamente apropriado pelo primeiro.
} 
contradição com essa função. A taxa de juros não pode ser corretamente ajustada de modo a equilibrar a acumulação.

O autor, sem muitas explicações, afirma que deve então haver concorrência, ainda que ela possa assumir muitas formas ${ }^{521}$. Ademais, em um sistema financeiro tão fragmentado, como em geral é o caso, seria difícil dizer onde reside exatamente o poder do dinheiro, e a acumulação de dinheiro em poucas mãos não significaria que esses poucos controlem ativamente o emprego do dinheiro.

Por outro lado, uma fragmentação total não seria desejável e não poderia corresponder às necessidades do capitalismo, de modo que, por exemplo, um banco central com poderes monopolistas é útil na garantia da qualidade do dinheiro. Assim, a tensão entre centralização e descentralização no bloco de poder fica, segundo Harvey, evidente em muitos aspectos, tais como: no fato de os EUA possuírem um sistema financeiro altamente descentralizado enquanto o capital monetário é extremamente concentrado em poucas famílias ou instituições; e na relação dos bancos, que competem em muitas áreas enquanto se aliam em outras. Enfim, seriam, pois, as contradições próprias da circulação do capital portador de juros que auxiliariam na compreensão das contradições existentes no seio do "bloco de poder" do capital financeiro.

Quanto à idéia de capital financeiro de Hilferding e Lênin - como uma união entre o capital bancário e o industrial - há que se considerar que essa união é seletiva: entre os maiores bancos e grandes empresas. Desse modo, afirma Harvey, o conceito de capital financeiro, sobretudo em Lênin, se fundiria com o de capitalismo monopolista em geral. Mais do que isso, Hilferding e Lênin entenderiam o capital financeiro também como uma unidade funcional entre as duas modalidades do capital, que dominaria o processo de acumulação e dividiria o mundo em regiões subordinadas ao poder desses poucos bancos e empresas gigantes.

Harvey argumenta, baseado no exposto acima, que essa unidade é tensa, permeada de antagonismos e contradições inerentes à circulação do capital portador de juros ${ }^{522}$. Esse ponto

${ }^{521}$ Cf. HARVEY, Limits to Capital, pp. 317-318.

${ }^{522} \mathrm{O}$ autor diz preferir a definição de capital financeiro dada por Thompson: "“Uma combinação articulada entre os capitais comercial, industrial e bancário' na qual o capital bancário é dominante, mas não determinante" HARVEY, Limits to Capital, p. 321, nota 18. Embora tente introduzir uma nuance na definição, essa formulação ainda parece não ser suficientemente precisa: o que quer dizer exatamente "dominante" e "determinante"?

De todo modo, a crítica geral feita a Hilferding é a de que sua concepção é "parcial" [one-sided] e "simplista", pois não explicaria como as contradições insuperáveis são internalizadas. Mesmo afirmando que o capital 
se relaciona com outro aspecto ao qual Chesnais não é alheio: a internalização desses antagonismos pelas empresas, que passam a se dedicar a atividades financeiras e produtivas, mas possuem setores "financeiros" e "produtivos" separados - o que abre espaço para conflitos internos. Por outro lado, essa unificação do controle proporciona às grandes empresas estratégias alternativas em tempos de crise, o que, contudo, modifica a luta competitiva entre elas e abre espaço para que "soluções financeiras" sejam cada vez mais comuns - em detrimento do incremento e reestruturação da produção -, algo inviável no longo prazo.

Para Harvey, o debate sobre quem controla quem, bancos ou indústrias, parece vão diante de um processo tão repleto de contradições. As oscilações de poder entre banqueiros e empresários são essenciais para se obter o equilíbrio mais apropriado entre atividades financeiras e produtivas com vistas à acumulação. Chesnais provavelmente não está em desacordo com esse princípio, mas conclui que as atuais condições do capitalismo provocam um desequilíbrio sistemático em favor da finança, afetando a acumulação. Além disso, para fins sociológicos é importante saber como se estruturam as relações de poder internamente à burguesia e, portanto, se existem frações industriais e financeiras e como elas se relacionam entre si.

Parte desse desequilíbrio de poder provavelmente tem a ver com a relação entre o capital financeiro e o Estado, que Harvey também comenta. $\mathrm{O}$ autor afirma que há uma parte do Estado, cujo cerne é o banco central, que está inteiramente comprometida com os interesses do capital portador de juros, pois ela é "necessariamente construída à imagem do movimento do próprio capital" ${ }^{\text {"523 }}$. Nesse sentido, é apresentada uma definição adicional do capital financeiro, em que os interesses do capital monetário, do capital industrial e do Estado são unificados.

Contudo, evidentemente essa unidade é contraditória, sobretudo em tempos de crise, quando o Estado - mesmo controlado claramente pela burguesia - deve usar seus poderes disciplinadores, entrando em conflito com as outras facções do capital. Por outro lado, um governo que represente os interesses dos trabalhadores pouco poderá fazer além de administrar as contradições e realizar pequenos ajustes institucionais, uma vez que uma parte do aparato estatal é reflexo do próprio capital. Segundo Harvey, somente a abolição da

financeiro não é capaz de superar as contradições do capitalismo, mas apenas de acirrá-las, Hilferding o faria de modo geral e vago, sem conseguir explicar como e por que isso ocorre.

${ }^{523}$ HARVEY, Limits to Capital, p. 322. 
circulação do capital portador de juros poderia permitir ao Estado escapar de um choque com o capital. Enquanto este não for o caso, a luta de classes é internalizada no Estado e este fica entre a servidão ao capital e o esforço para satisfazer as demandas dos trabalhadores.

Harvey enfatiza, por fim, que a situação se torna ainda mais problemática no plano internacional, em que os bancos centrais de diversos paises precisam se relacionar. A posição que o país ocupa no cenário internacional pode afetar a capacidade de seu banco central de responder às dificuldades internas da acumulação de capital. Além disso, as políticas cambiais, tarifárias, etc. podem levar a disputas entre países. Hilferding e Lênin se debruçaram exatamente sobre a conexão entre capital financeiro, Estado e rivalidades imperialistas. A diferença entre os dois estaria em que Hilferding focou na aliança entre capital bancário e industrial no âmbito do Estado - levando-o a minimizar as contradições internas e a realçar as lutas no plano mundial -, ao passo que Lênin teria ido além e considerando os aspectos supranacionais da circulação do capital portador de juros - visto as operações financeiras como um meio específico de se controlar governos mundo a fora.

Assim, em resumo:

Enquanto o aparato estatal forma o núcleo do centro de controle estratégico da circulação do capital portador de juros, este é ao mesmo tempo livre para circular de modo a disciplinar para seus propósitos os Estados-nações. O Estado tanto controla como é controlado em sua relação com a circulação de capital. ${ }^{524}$

${ }^{524}$ HARVEY, Limits to Capital, p. 324. 


\section{OBSERVAÇÕES FINAIS}

A análise em conjunto das obras de François Chesnais e David Harvey permite afirmar que se Marx não fornece diretamente uma formulação que permita conceber uma fase de "dominância financeira" do capitalismo, mostrou-se possível encontrar elementos em sua teoria para elaborar tal tese, uma vez abandonada uma visão mais geral e abstrata do capitalismo e que se busque uma compreensão adequada do fenômeno da financeirização. Esta deve ser compreendida como um processo não só econômico, mas político e social, que engendra uma nova situação na luta de classes e incrementa o predomínio do capital - pondo o capital financeiro no centro das relações sociais e econômicas e conferindo uma série de características específicas (embora nem todas inéditas) ao capitalismo. Alteram-se também os circuitos predominantes de valorização do capital e a relação entre as frações internas da classe capitalista.

A fim de apreender melhor a contribuição das obras de Harvey e Chesnais para a compreensão do modo pelo qual o capitalismo evolui, talvez seja interessante, primeiramente, retomar a distinção entre o que se denominou padrão de acumulação e forma de produção. Trata-se de duas abordagens indissociavelmente presentes na maioria das análises do capitalismo, mas cujo peso varia consideravelmente de autor para autor. Assim, a forma de produção está presente, por exemplo, em estudos de sociologia do trabalho que comparam as diferentes épocas do capitalismo a partir da evolução das relações de trabalho e da sua organização. Ela encontra-se também, ainda que de forma subjacente, nos trabalhos de Eleutério Prado, que focam a questão da subsunção do trabalho ao capital.

Embora Harvey se refira, em Condição pós-moderna, a uma "acumulação flexível", nesse livro ele se concentra preferencialmente na forma de produção, o que não deixa de gerar certas confusões na sua análise. Somente quando introduz a questão da financeirização é que sua ótica parece de fato se voltar progressivamente para o padrão de acumulação, até o ponto de ele admitir que o elemento realmente novo no capitalismo é exatamente a "virada financeira".

O que se chama aqui de padrão de acumulação em muitos aspectos se assemelha ao que os regulacionistas entendem por regime de acumulação, devido à sua abrangência. A 
principal diferença reside em que este conceito possui um caráter mais específico, por estar associado a determinada corrente teórica ${ }^{525}$. O termo "padrão de acumulação" busca enfatizar o fato de que a acumulação do capital se apresenta como critério decisivo da análise para a compreensão da evolução do capitalismo, independentemente dela abarcar ou não todos os elementos institucionais que definem um regime de acumulação ${ }^{526}$.

Pode-se considerar que tanto a análise de Chesnais, quanto a que Harvey empreende em $O$ novo imperialismo, privilegiam o padrão de acumulação. Em Chesnais isso é bastante nítido devido à utilização do conceito de regime de acumulação, assim como à sua preocupação em identificar as mudanças nos circuitos de valorização do capital e a dominância de certo tipo de capital sobre outros. Em parte como consequiência disso, as mudanças percebidas na forma de produção (flexibilização, terceirização, deslocalização, etc.) são subsumidas ao padrão de acumulação e muitas vezes tratadas como conseqüências da alteração desse padrão.

Harvey, por sua vez, identifica nas últimas décadas uma primazia da acumulação por espoliação no capitalismo em relação aos processos moleculares de valorização do capital. Ou seja, ele aponta uma mudança nas formas do capital se acumular. É preciso lembrar que, embora, em Condição pós-moderna, o autor já reconheça importância da financeirização, permanecia a ambigüidade entre uma abordagem voltada para a forma de produção e outra

\footnotetext{
525 Nesse sentido, há uma diferença marcada entre conceitos como o de "regime de acumulação"/“modo de regulação" e os termos "padrão de acumulação"/“forma de produção". Para além de serem conceitos intimamente associados a uma escola de pensamento específica, o primeiro par é composto de instrumentos "analíticos" para se apreender o capitalismo e captar suas mudanças (conjunto de fatores a serem identificados e observados). Já o padrão de acumulação e a forma de produção, embora também sirvam a fins analíticos, remetem a concepções "metodológicas" diferentes, ou seja, a que elemento do capitalismo se privilegia (consciente ou inconscientemente) na construção teórica.

${ }^{526}$ Isso significa que, embora o padrão de acumulação seja, a princípio, mais abrangente do que a forma de produção, uma análise focada no padrão de acumulação não é necessariamente mais "profunda" nem implica a concepção de mudanças mais "radicais". Esses termos se referem a como se concebe a transformação.

Um exemplo é o texto de Anwar Shaikh, centrado no padrão de distribuição de riqueza, que figura como um dos componentes fundamentais do regime de acumulação - que, por conseqüência, possui relação direta com o padrão de acumulação. Ele apresenta dados que revelam os resultados do neoliberalismo, pois mostra uma diferença entre o período fordista e o atual. A queda continuada da taxa de lucro (derivada da crise dos anos 60/70) é freada a partir do início dos anos 80 devido às medidas neoliberais, que reorientam a repartição da riqueza em prol do capital. A produtividade e a remuneração do trabalho vinham caminhando juntas (durante os 30 anos dourados) e se separam, a primeira crescendo mais rapidamente do que a segunda (durante os últimos 25 anos).

Sobre a questão mais geral do padrão de acumulação (e sem mencionar questões relativas à forma de produção, nem grandes mudanças do capitalismo), portanto, Shaikh mostra como havia uma relação mais estreita entre os ganhos de produtividade e de salários (devido ao arranjo institucional e situação política em vigor) e que nos anos 80 isso se altera em benefício do capital. Há, portanto, mais exploração do trabalho e um padrão distributivo que beneficia o capital. Desse modo, há a passagem de uma "solidariedade" entre ganhos de produtividade e de salários para ganhos maiores do capital em detrimento dos salários.

Cf. SHAIKH, "La Primera Gran Depresión del Siglo XXI”, sobretudo os gráficos da p. 6.
} 
para o padrão de acumulação. As mudanças na produção e a financeirização parecem então processos simultâneos, mas sua conexão não fica nítida. É só com $O$ novo imperialismo que a financeirização fica em evidência, o foco assentando no padrão de acumulação.

É possível inferir, portanto, que os trabalhos que destacam a questão da financeirização conferem um peso maior ao estudo e acompanhamento do padrão de acumulação, pois ela é um processo que se refere principalmente à forma de o capital se acumular. Nesse sentido, parece razoável supor que Eleutério Prado, por priorizar a forma de produção, é levado a rejeitar muitas das teses de Chesnais. Isso se deve, em parte, a uma diferença de pontos de partida, relativa a como caracterizar as mudanças do capitalismo.

Contudo, nunca é demais ressaltar que a diferença entre padrão de acumulação e forma de produção não é radical, mas se trata antes de uma questão de ênfase. Considerando-se o conceito de regime de acumulação, fica evidente que uma mudança na acumulação não pode ocorrer sem que transformações essenciais aconteçam no âmbito da organização/relações de trabalho e de produção de mercadorias - no qual a valorização do capital se processa. Por outro lado, mudanças importantes na forma de produção e principalmente na subsunção do trabalho ao capital devem necessariamente engendrar, e ao mesmo tempo assinalar, uma mudança mais geral nos padrões de acumulação do capital. Em suma, ambos são expressão de um mesmo processo de transformação do capitalismo e devem ser tratados de forma articulada.

Quando não se procede dessa forma, corre-se o risco de cair em uma espécie de determinismo (relação de causa e conseqüência) de um pelo outro. Chesnais de certa forma acaba relegando as mudanças na forma de produção a conseqüências da mudança no regime de acumulação e da dominância do capital financeiro no seio das empresas produtivas ${ }^{527}$.

${ }^{527}$ Prado, por outro lado, encara as mudanças mais profundas relativas à acumulação como decorrência da mudança na forma de produção, ou seja, da desmedida do valor provocada pela penetração da ciência no cerne da produção. Nesse sentido, as teorias de Prado e Chesnais talvez possam ser compatibilizadas mais facilmente do que a crítica do primeiro ao segundo admite. Porém, seria necessária uma reflexão pormenorizada para estabelecer as compatibilidades e incompatibilidades das duas teorias, o que não cabe aqui. Sugere-se apenas que elas dizem respeito a processos diferentes: a hipertrofia da esfera financeira e seu impacto na lógica geral de reprodução do capital não excluem a possibilidade de uma mudança no modo de produção das mercadorias e vice-versa. Um fenômeno não necessariamente contradiz o outro e poderiam até ser complementares. 
Uma vez estabelecida essa dimensão geral das pesquisas de Chesnais e Harvey, convém debruçar-se um pouco sobre outras questões atinentes ao papel que a financeirização ocupa na compreensão do capitalismo contemporâneo.

Viu-se que Harvey trata de vários aspectos do capitalismo, dentre eles e em relação com eles, a financeirização, que curiosamente possui uma posição de destaque em muitos de seus trabalhos sem ser, contudo, objeto de análise específica. Ela é constitutiva do capitalismo contemporâneo, confere especificidade e elementos novos a ele, mas seu lugar na teoria de Harvey parece incerto. Em Limits to Capital (1982), o tratamento de questões como dinheiro, sistema de crédito, capital portador de juros e capital fictício é abstrato, constituindo-se numa discussão teórica focada em $O$ Capital. Em Condição pós-moderna (1989) a questão da financeirização começa a surgir e a ser contextualizada, mas sua posição ainda é ambígua: é apresentada como a novidade do capitalismo e talvez como ponto central a ser investigado, ao mesmo tempo que é concebida como mais um componente do complexo mosaico representado pelo "regime flexível de acumulação".

Em $O$ novo imperialismo (2003) e em $O$ neoliberalismo (2005), a avaliação da financeirização como elemento fundamental do capitalismo contemporâneo encontra-se consolidada, porém subsumida, como os títulos das obras já indicam, à discussão das questões referentes ao imperialismo e ao neoliberalismo. Sua presença nessas obras, mesmo que aparentemente de forma secundária, atesta sua importância crucial, já que permite articular esses diferentes processos constitutivos do capitalismo atual ${ }^{528}$.

Em Chesnais, por sua vez, a primazia da financeirização é evidente, até porque compreendida de forma ampla: marca a ruptura com o período fordista e sinaliza um processo muito abrangente de mudanças - sendo, por isso, definida como um novo regime de acumulação. Quase na contramão de Harvey, a financeirização parece englobar os demais fenômenos: a reestruturação produtiva decorre das pressões da finança por liquidez e valorização acionária; o neoliberalismo é a expressão do "golpe de Estado" da finança; a fase atual do imperialismo é a projeção do poder do capital financeiro em escala mundial; e assim por diante.

\footnotetext{
${ }^{528}$ Um dos pontos que talvez diferencie Harvey de Chesnais é quanto ao peso da "novidade" representada pela virada financeira. Na formulação de Leda Paulani e Niemeyer Almeida Filho: "há coincidência nas formulações de Chesnais e Harvey quanto à dinâmica do capitalismo contemporâneo, embora para o primeiro essa dinâmica tenha algo de inédito, enquanto que, para o segundo, a dinâmica financeirizada pode ser vista como um desdobramento histórico compatível com a natureza mesma do capitalismo" - PAULANI e ALMEIDA FILHO, "Regulação social e acumulação por espoliação", p. 13.
} 
Por outro lado, em alguma medida talvez seja apenas uma questão de conceituação. Harvey - circunscrevendo a financeirização a fatores tais como a expansão e desregulamentação dos mercados financeiros, a multiplicação do capital fictício, o surgimento de novos atores ligados ao capital financeiro - precisa recorrer a outros elementos para "completar o quadro" do capitalismo contemporâneo. Já Chesnais, concebendo a financeirização como a configuração mais ampla, em vários níveis, do capitalismo atual, precisa apenas distinguir e explicitar o que é abarcado pelo conceito.

Harvey e Chesnais possuem, assim, perspectivas diferentes, mas de certo modo complementares: Chesnais confere coerência a uma série de fenômenos, reunindo-os sob o ponto de vista geral da financeirização, ao passo que Harvey, operando com uma concepção mais circunscrita desta, aprofunda a análise dos demais aspectos do capitalismo, sem deixar de relacioná-los à questão financeira. Este talvez consista num dos benefícios de uma abordagem conjunta dos dois autores. A obra de Harvey contribui para explicitar o que faz parte desse conceito tão amplo de financeirização adotado por Chesnais. Por outro lado, dada a ausência de uma visão específica sobre a financeirização em Harvey, Chesnais contribui para a compreensão de como a financeirização articula os conceitos de imperialismo, neoliberalismo e acumulação flexível.

O foco na questão da financeirização traz ainda outras características à análise. Em primeiro lugar, quando se privilegia o padrão de acumulação, obtém-se uma descrição potencialmente mais abrangente do funcionamento do capitalismo. Não é necessário que todos os países estejam liberalizados e abertos ao capital financeiro, que todas as empresas tenham se reformulado e se financeirizado para que certas proposições sobre o capitalismo contemporâneo tenham validade. Uma vez as principais economias e grandes corporações operando nessa chave, cria-se, em razão do atual estágio de mundialização do capital, um "ambiente financeirizado" no qual todos estão mais ou menos inseridos, mas dificilmente $\operatorname{apartados}^{529}$.

${ }^{529}$ O que já não é o caso quando se privilegia a forma de produção, como em Eleutério Prado: para que as proposições mais gerais tenham validade, seria necessário que houvesse a subsunção intelectual do trabalho ao capital não só nas grandes empresas ou em setores-chave da economia, mas de fato em todas ou na maioria das empresas - o que precisaria ser devidamente demonstrado. 
Outra característica da abordagem do capitalismo pela ótica da financeirização é que ela ilumina especialmente certas zonas "fronteiriças". O desenvolvimento da esfera financeira - com a geração constante de capital fictício e de bolhas -, associado ao caráter enigmático e abstrato dos mercados financeiros - que lhes confere ares de autonomia -, cria uma aparência que pode confundir a análise. Tal "aparência" não é, deve-se enfatizá-lo, uma ilusão ou falsidade, mas algo a ser compreendido dialeticamente - premissa indispensável ao próprio entendimento da financeirização ${ }^{530}$. Essa questão é tão complexa que o próprio Chesnais, por transitar, ora de modo desavisado, ora sem avisar o leitor, entre o "aparente" e o "essencial", acaba alvo de críticas, como na questão da "autonomia relativa" da esfera financeira e da compreensão do capital financeiro ${ }^{531}$.

A dificuldade de compreensão, por exemplo, da "realidade" do capital fictício muitas vezes advém da necessidade de se pensar dialeticamente. O capital fictício é real para o indivíduo, que pode converter seu título em riqueza efetiva ou até mesmo usá-lo como dinheiro, mas fictício do ponto de vista da totalidade, já que não há criação de riqueza nova

${ }^{530}$ Um dos méritos dos autores que se propõem a estudar a financeirização é exatamente o de não desistir da investigação por ter que tratar da aparência. Eles a entendem como tal, como algo que pode iludir, mas que é real, e não "falso" (e, portanto, sem importância). A aparência é fundamental para se compreender uma série de aspectos do capitalismo. Os frankfurtianos, por exemplo, foram buscar no plano dos fenômenos "derivados" e da ideologia respostas para certas questões essenciais sobre o capitalismo. Também Marx teve que articular produção e circulação, essência e aparência, para desvendar os segredos da exploração capitalista. Nesse sentido, mesmo ao se fazer uma crítica radical da abordagem da financeirização - no sentido de lhe negar pertinência, na medida em que a esfera financeira e o capital portador de juros são inteiramente dependentes dos processos produtivos - ainda assim não é menos necessário estudar e explicar os fenômenos "aparentes" que fazem parte da financeirização.

${ }^{531}$ Chesnais é por vezes acusado (isso transparece, por exemplo, na crítica feita em PRADO, "Resenha de 'A finança mundializada"') de conceber o capital financeiro como um tipo diferente de capital, distinto do produtivo e não como uma forma de circulação do capital que inevitavelmente está atrelada ao capital industrial. Ele é igualmente acusado de localizar nos anos 1980 o "ressurgimento" do capital portador de juros, negligenciando o fato de que o capital portador de juros é inerente ao capital e, portanto, sempre existiu na história do capitalismo. Embora a falta de rigor terminológica do autor mereça mesmo uma crítica, como já se apontou anteriormente, o que está por trás da questão parece ser o fato de Chesnais, provavelmente por influência de Hilferding, considerar muito na análise os atores ligados aos interesses financeiros ou produtivos. Trata-se do que Harvey caracterizou como uma visão do capital financeiro centrada no "bloco de poder" (embora Chesnais não exclua de forma nenhuma da análise a questão da forma de circulação). Nesse sentido, a impressão de uma concepção do capital financeiro como um tipo distinto de capital está ligada ao fato dele ter atrás de si atores, instituições, forças políticas (além do modo de circulação) diferentes daqueles associados ao capital produtivo.

Do mesmo modo, o que ressurgiu nos anos 80 não foi propriamente a forma do capital portador de juros, mas a predominância de uma fração da burguesia diretamente ligada à "valorização financeira" (devido ao fato, evidentemente, desta subordinar os processos produtivos de valorização). É o que se depreende também de Duménil e Lévy: "Nos Estados Unidos, a expressão 'repressão financeira' é utilizada para designar o recuo das prerrogativas da finança (...) Com o advento do neoliberalismo, a finança pôde retornar à situação que lhe era vantajosa. Sob o ponto de vista da hegemonia financeira, pode-se falar de restabelecimento, muito mais do que de prosseguimento de uma mesma evolução" - DUMÉNIL e LÉVY, "Superação da crise, ameaças de crises e novo capitalismo", p. 34 (itálico nosso). 
em termos sociais e que a conversão em dinheiro da integralidade dos títulos fíctícios ao mesmo tempo é impossível. Assim explicam Carcanholo e Sabadini:

Esse capital fictício de três diferentes origens tem em comum o fato de que, ao mesmo tempo em que é fictício, é real. É real do ponto de vista do ato individual e isolado, no dia-a-dia do mercado, quer dizer, do ponto de vista da aparência; é a dialética fictício/real ${ }^{532}$. [Posteriormente:] A ausência de uma visão dialética (...) impede de ver que o 'capital financeiro', o capital fictício, ao mesmo tempo que é fictício, é real. Isso ao mesmo tempo! $!^{533}$

Desse modo, a compreensão da financeirização explicita a necessidade de se mobilizar na análise várias "dialéticas", tais como entre real/fictício, essência/aparência, individualidade/totalidade.

Outra "fronteira" a que o conceito de financeirização remete é entre "político" e "econômico",534. A intersecção entre o foco de Harvey na crise de sobreacumulação e sua teorização sobre a acumulação por espoliação, por um lado, e a apresentação que Chesnais faz do processo de constituição do regime financeirizado, por outro, ajuda a discernir a interpenetração entre economia e política no capitalismo contemporâneo.

A crise de sobreacumulação que anunciou o fim do fordismo possui evidentemente suas razões específicas e um contexto histórico, econômico e político determinado. Contudo, não faz parte deste trabalho essa discussão, bastando ter em mente que tal crise, como as demais, é, de forma geral, gerada pelo próprio movimento contraditório da acumulação do capital - que Marx explicou, mesmo que de forma abstrata - ao qual mesmo o intervencionismo e as políticas anti-cíclicas do keynesianismo não puderam se contrapor inteiramente. Portanto, é possível partir da crise de acumulação dos anos 60/70 para se obter uma compreensão histórica dos desenvolvimentos que culminaram na atual fase do capitalismo.

Procedendo dessa forma, constata-se que um problema fundamental no plano econômico instalou-se principalmente nos países centrais, demandando uma solução

\footnotetext{
${ }^{532}$ CARCANHOLO e SABADINI, "Capital fictício e lucros fictícios”, p. 45.

${ }^{533}$ Ibidem, p. 60.

${ }^{534}$ Esse tipo de distinção é bastante delicado. Não se pretende fazer essa discussão aqui, mas é necessário observar o seguinte: por um lado, os termos "político" e "econômico" devem ser distinguidos, pois se referem a duas ordens distintas de fenômenos e processos. É o que está subjacente à distinção de Harvey entre lógica territorial do Estado (política) e lógica capitalista (econômica). Por outro lado, não se quer absolutizar tal distinção, uma vez que política e economia possuem vínculos estreitos, não podendo ser tratadas separadamente uma da outra.
} 
adequada - de ordem econômica, decerto, mas que também exige novas modalidades de ações políticas. Dessa perspectiva, surge o que Chesnais designou como o "golpe de Estado" da finança e que faz parte da reorientação política que ele próprio, mas também Harvey (que a analisou mais profundamente) e outros autores denominaram "neoliberalismo". A conseqüência, mas em certa medida também o intuito, foi uma alteração do papel do Estado e das relações políticas internas e externas dos países, modificando sua configuração sistêmica.

A esse respeito, deve-se ponderar, entretanto, que a financeirização (diferentemente do que Chesnais sugere algumas vezes ${ }^{535}$ ) não parece resultado exclusivamente de uma escolha política livre e deliberada, uma vez que havia, na realidade, certo estreitamento das opções para os detentores do capital. O movimento que instaura a financeirização surge, assim, como resposta, em alguma medida plausível e adequada, ante as exigências irrefreáveis de valorização do capital. Isso fica implícito na análise de Harvey, quando considera a flexibilidade (na qual a financeirização está inserida) como uma resposta necessária à crise de sobreacumulação. Esse também é o sentido dado por Arrighi, que concebe as expansões financeiras como a principal solução historicamente ${ }^{536}$ disponível pelo capitalismo diante do esgotamento de suas fases de expansão material.

No plano econômico, por sua vez, surgem diversas iniciativas por parte das empresas visando reformular a organização da produção por meio do corte despesas e do aumento da produtividade - a assim chamada reestruturação produtiva. Elas se dão em grande parte paralelamente às mudanças políticas, porém a penetração dos interesses financeiros diretamente no comando das empresas - que é também produto das mudanças políticas possui, como salienta Chesnais, um papel importante no sentido de estimular e aprofundar esse processo - talvez até mesmo de iniciá-lo, em muitos casos. Desse modo, as respostas

\footnotetext{
${ }^{535}$ Mas também outros autores, talvez até mais explicitamente. Duménil e Lévy, por exemplo, falando do neoliberalismo e da retomada da finança, afirmam: "Este foi um processo consciente, deliberado, cuidadosamente orquestrado, e não o resultado de um mecanismo de mercado qualquer" - Cf. DUMÉNIL e LÉVY, "Superação da crise, ameaças de crises e novo capitalismo", p. 32.

536 Historicamente, pois Postone ressalta que o padrão de desenvolvimento que Arrighi "delineia é essencialmente descritivo. Ele não apresenta, de fato, uma análise acerca do que move o padrão de desenvolvimento que ele descreve" - Cf. POSTONE, "Teorizando o mundo contemporâneo: Robert Brenner, Giovanni Arrighi, David Harvey", p. 88.

Para reforçar o argumento, portanto, pode-se invocar, por exemplo, o desenvolvimento categorial/lógico apresentado por Paulani - que enfatiza que o capital portador de juros e o capital fictício são as formas mais desenvolvidas da contradição inerente ao capital. Ele pode oferecer, assim, um caminho para se justificar, de fato, que, diante de uma "barreira" no âmbito da acumulação, o capitalismo é conduzido a superá-la através da financeirização, levando, na realidade, essa barreira a ser transposta a um nível superior, como indica Marx. Cf. PAULANI, "A autonomização das formas verdadeiramente sociais na teoria de Marx: comentários sobre o dinheiro no capitalismo contemporâneo".
} 
políticas fornecidas ao problema econômico da sobreacumulação desempenham um papel crucial na mudança do capitalismo - conferindo-lhe uma nova configuração.

Porém, há ainda, como mostra Harvey, um aspecto mais específico do capitalismo financeirizado no qual política e economia se entrelaçam. Trata-se da acumulação por espoliação. Ela se torna especialmente importante como instrumento para contornar ou tentar solucionar problemas de sobreacumulação do capital, ou seja, como forma de resolver uma questão econômica. Por outro lado, a ação do Estado é imprescindível para colocar em prática os mecanismos espoliativos, de modo que ele se utiliza destes também para fins geopolíticos próprios, alterando, assim, a relação entre Estados ou regiões (imperialismo).

A acumulação por espoliação possui, portanto, inegavelmente uma faceta estritamente política. Uma vez que o capital financeiro é um de seus veículos, ele tanto opera tais processos "econômico-políticos" como faz parte deles. Em sua dimensão destrutiva, por exemplo, o capital financeiro, ao desencadear (ou se aproveitar de) uma crise ou turbulência em determinado país (ou região), abre oportunidades de investimentos lucrativos - por meio da obtenção a baixo preço de ativos desvalorizados pela crise. Ao mesmo tempo, amplia a subordinação do país tanto ao capital estrangeiro como, talvez, a instituições ou Estados (no caso de uma necessidade de empréstimo de dinheiro, por exemplo).

Assim, mesmo se alguns autores, inclusive marxistas, considerem exagero tratar a "virada financeira" como uma mudança do regime de acumulação, não se pode negar a presença de uma inflexão importante em vários aspectos que não pode ser negligenciada. Por meio da exposição das teorias de Chesnais e de Harvey, procurei mostrar alguns desses aspectos. Dentre eles, cabe mencionar a questão do processo de monopolização e mundialização do capital. Se é verdade que se trata de um movimento iniciado já no fim do século XIX, não é possível afirmar, contudo, que ele seja homogêneo e contínuo e que nada tenha mudado no desenvolvimento capitalista desde então.

Por mais que possa haver exagero na força e na dominância atribuídas por Odile Castel $^{537}$ às grandes corporações (sobre os Estados nacionais) ${ }^{538}$, ela tenta mostrar exatamente

\footnotetext{
${ }^{537}$ CASTEL, "La naissance de l'ultra-impérialisme. Une interprétation du processus de mondialisation”.

${ }^{538}$ É complexo mensurar e comparar o poder de corporações multinacionais e de Estados, sendo necessário analisar muitos dados e construir uma argumentação muito detalhada. Em favor da posição de Castel, pode-se mencionar os dados sobre a concentração de riqueza e de poder financeiro nas mãos das grandes multinacionais que ela própria apresenta, assim como o fato de que muitas destas detêm riqueza maior do que o PIB de muitos países. A influência dessas multinacionais sobre governos e sobre instituições internacionais dificilmente é, pois, pequena, e Castel cita 3 instrumentos de dominação fundamentais: os programas de ajuste estrutural, a OMC e o
} 
uma clivagem entre a situação do imperialismo antes e depois dos anos 1970, em parte com o apoio dos apontamentos de Chesnais sobre a mundialização do capital ${ }^{539}$. Ela argumenta que entre 1880 e os anos 1970 o capitalismo passava por um estágio do imperialismo tal como definido por Lênin, ao passo que no período seguinte suas características se aproximam mais do conceito de "ultra-imperialismo", proposto por Kautsky. Ela sintetiza cinco das características que Lênin atribui ao imperialismo e as adapta para descrever a configuração nascente deste. As principais diferenças estariam em que atualmente: os oligopólios não são mais de porte nacional, mas internacional, com influência decisiva na vida econômica das nações (de modo que eles não estão mais subordinados ao poder e aos interesses geopolíticos dos Estados como antes); a fusão do capital bancário e do capital industrial também ocorre em escala mundial; o comércio intra-firmas ganha uma importância particular no comércio mundial (ao lado do comércio entre países); os oligopólios dividem diretamente o mundo entre si ao invés de formarem associações internacionais de monopólios nacionais; e houve uma passagem de uma lógica geopolítica (predomínio do Estado) para uma lógica geoeconômica (em benefício dos oligopólios mundiais) ${ }^{540}$.

Nesse sentido, se, como defende Harvey, o crédito e a circulação do capital portador de juros funcionam como uma espécie de "sistema nervoso central" (uma força coordenadora) do capitalismo, a mundialização crescente do capital requer inevitavelmente uma esfera financeira cada vez mais desenvolvida. Assim, além de ser impulsionada pela crise de sobreacumulação dos anos 70, a financeirização pode ser considerada como um fenômeno intimamente associado à mundialização do capital e, portanto, à oligopolização e transnacionalização das empresas ${ }^{541}$. Como observam Paulani e Almeida Filho, para Harvey

acordo multilateral de investimentos (este último foi abortado, dada a enorme controvérsia que gerou). Por outro lado, não se pode deixar enganar pela ideologia neoliberal do "fim do Estado". Como Harvey bem observa, houve uma mudança no papel do Estado, mas não necessariamente seu enfraquecimento. A oposição entre uma lógica territorial e uma lógica capitalista (que aqui se chamou de "estatal" e "econômica" respectivamente) continua presente e engendrando contradições importantes. Ademais, as multinacionais operam em contextos e legislações nacionais e ainda repatriam lucros às matrizes (mostrando que continuam possuindo vínculos com seus países de origem).

${ }^{539}$ Relacionando a questão do imperialismo com a da periodização do capitalismo baseada na forma de produção ou no padrão de acumulação, evoca-se a seguinte passagem de Chesnais: "o imperialismo não 'percorre' fases sucessivas; ao contrário, conheceu uma história cujos segmentos são marcados ou separados tanto por fases distintas da luta de classes e das mudanças correspondentes nas relações políticas entre as classes (...) como por mudanças no âmbito dos mecanismos endógenos à acumulação" - CHESNAIS, "États rentiers dominants et contraction tendencielle (...)", pp. 99-100 (itálico consta do original; negrito nosso).

${ }^{540}$ Ver o resumo dessas características em CASTEL, "La naissance de l'ultra-impérialisme (...)”, pp. 123 e 131.

${ }^{541}$ Nunca é demais, pois, ressaltar que financeirização não significa uma perda de importância das empresas "produtivas". Ao contrário, há a formação de grandes conglomerados transnacionais "predominantemente industriais", que se utilizam das estratégias financeiras para incrementar seus lucros e submeter concorrentes e 
"a dinâmica financeirizada pode ser vista como um desdobramento histórico compatível com a natureza mesma do capitalismo, assentada na contradição entre duas lógicas, a do capital e a do espaço político" ${ }^{\text {542 }}$. Postone parece ter a mesma avaliação, ao defender que Harvey concebe as finanças como produto do próprio capital ${ }^{543}$.

A compreensão do desdobramento do capitalismo que leva à financeirização vinculase diretamente à questão da sobreacumulação do capital. Tomando em consideração o trabalho de Harvey, isso significa que a financeirização se encontra também intimamente associada à questão da espoliação, pois o ganho de importância da acumulação por espoliação na reprodução do capitalismo está diretamente ligado às dificuldades de valorização do capital por meio de seus processos "moleculares". Em geral, a acumulação por espoliação se processa por meio da abertura de novos canais de aplicação de capital. Ora, a transferência maciça de capital para a esfera financeira, em busca de "valorização financeira", pode ser explicada como uma expansão das fronteiras de investimento do capital num cenário de dificuldades de valorização na esfera produtiva ${ }^{544}$.

Porém, o setor de investimento constituído pelas aplicações financeiras é bastante problemático. Por um lado, por meio do sistema de crédito, o investimento financeiro pode estimular a produção e produzir os lucros que o remunerem. Por outro lado, a dimensão fictícia que inevitavelmente assume - permeada pelo fetichismo do capital portador de juros alimenta a ilusão de que dinheiro produz dinheiro ("como pereira dá pêras"). Nesse sentido, o deslocamento de capital para o setor financeiro parece não ser uma solução adequada para o

empresas menores. Contudo, eles também se tornam objeto das punções da finança, transferindo parte dos lucros para as mãos de capitalistas financeiros e reorientando suas atividades nessa direção.

Além disso, a relação entre "globalização" e financeirização é direta, pois seria difícil imaginar tal integração econômica entre os países apenas em termos comerciais e de investimento industrial, sem uma abertura financeira que liberasse os fluxos de capital monetário.

${ }^{542}$ PAULANI e ALMEIDA FILHO, "Regulação e social e acumulação por espoliação (...)", p. 13.

${ }^{543}$ Cf. POSTONE, "Teorizando o mundo contemporâneo (...)", nota 31.

${ }^{544}$ Evidentemente, tanto a espoliação quanto o capital portador de juros não surgem na atual fase. A espoliação é, de certa forma, constitutiva do próprio capitalismo. A diferença da espoliação na produção (extração direta de mais-valia) para as demais formas é que ela é recoberta pela ideologia da troca de equivalentes entre indivíduos formalmente iguais (sendo por isso distinguida por Harvey da acumulação por espoliação). Quanto ao capital portador de juros, já se enfatizou que ele é uma forma logicamente, mas não historicamente, posterior do capital. Ele existe como uma decorrência inevitável da constituição plena do dinheiro. O que marca a atual fase do capitalismo é a centralidade que a espoliação e o capital portador de juros ganham nas relações econômicas e sociais capitalistas. 
problema da sobreacumulação ${ }^{545}$. Como a esfera financeira em si não pode gerar riqueza, sua operação depende de processos espoliativos, ou seja, da capacidade de drenar recursos de outros lugares. Como bem expressa a metáfora de Eleutério Prado, "o capital fictício é o capital que ultrapassa a si mesmo, que se levanta puxando os cordões do próprio sapato" ${ }^{, 56}$.

As considerações de Chesnais e Harvey sobre as conseqüências desses processos para a acumulação do capital parecem, à primeira vista, opostas. Harvey menciona uma situação de sobreacumulação mal resolvida, já que os deslocamentos espaço-temporais e as formas espoliativas de acumulação, entre elas a financeirização, têm evitado que haja crises de desvalorização do capital suficientes para uma acumulação sustentada do capital voltar a ocorrer. Chesnais, por sua vez, defende que um dos principais efeitos da financeirização é criar uma situação perene de baixa acumulação do capital ${ }^{547}$, uma vez que parte crescente da mais-valia é redirecionada para os mercados financeiros ou repassada como dividendos aos acionistas das empresas.

Contudo, essa oposição é, em certa medida, aparente, sendo antes uma questão de perspectiva. Primeiro, convém ressaltar que "sobreacumulação" é um conceito relativo, designando a existência de capital além das possibilidades abertas de investimento lucrativo, sejam elas muitas ou poucas. A baixa acumulação, por sua vez, não é sinônimo de baixos índices de exploração do trabalho ou de lucratividade. Ao contrário, atualmente há lucros elevados, porém a acumulação só ocorre quando a mais-valia é reinvestida na produção de modo a reiniciar e ampliar o ciclo de produção. Se a mais-valia, mesmo elevada, não é reinvestida na produção - sendo distribuída sob forma de rendas (juro, renda da terra, etc.) ou gasta em consumo - há baixa acumulação do capital. Portanto, ela também é uma noção relativa, ao se basear em quanto o capital poderia se acumular caso uma fração maior da maisvalia fosse reinvestida na produção.

Nesse sentido, não há necessariamente contradição em se apontar uma situação de baixa acumulação com sobreacumulação. Pelo contrário, a baixa acumulação pode precisamente ser efeito da sobreacumulação não resolvida. A financeirização é uma resposta "natural", porém irracional, à crise de sobreacumulação. Ela abre possibilidades de

\footnotetext{
545 Novamente volta-se à dialética entre indivíduo e totalidade: para o indivíduo que converte seu dinheiro em capital monetário investido nas finanças, pode se tratar de uma solução para o investimento de sua riqueza. No entanto, do ponto de vista da totalidade não há uma renovação efetiva das possibilidades de valorização produtiva.

${ }_{546}^{5}$ PRADO, "Resenha de 'A finança mundializada"”, p. 4.

${ }^{547}$ Leia-se baixa acumulação do capital industrial, que, segundo Marx, expressa de fato acumulação de capital.
} 
investimentos na esfera financeira para escoar o capital sobreacumulado. Contudo, as punções que realiza sobre a esfera produtiva, exatamente para poder proporcionar rentabilidade ao capital, acabam comprometendo a acumulação do capital. A acumulação é mantida em níveis menores ao mesmo tempo que a sobreacumulação não é resolvida (apenas desviada), pois não ocorrem as necessárias desvalorizações. O que seria um remédio se interverte, por conseguinte, em parte do problema ${ }^{548}$.

Para além dessa "contração tendencial" ${ }^{, 549}$ do sistema ${ }^{550}$, Chesnais apresenta outro traço fundamental da atual fase do capitalismo, extraído das análises de Lênin: a criação de um "Estado-rentista", cuja burguesia se alimenta da exportação de capital e de rendimentos de títulos. Esse ponto é essencial para a compreensão da especificidade do capitalismo contemporâneo, como enfatizam Paulani e Almeida Filho: "o que Chesnais destaca como sendo novo é o protagonismo que a propriedade e o rentismo assumiram, bem como o alojamento dessa posição de exterioridade à produção no seio da própria produção" ${ }^{\text {"551 }}$. Caso sejam acrescentadas as contribuições de Harvey acerca da acumulação por espoliação, tem-se uma dimensão da relação estabelecida entre financeirização, rentismo e espoliação.

Chesnais define a atual conformação do capitalismo sob a égide das finanças como a dominância da "propriedade patrimonial", encarnada nos detentores de ações e outros títulos financeiros passíveis de gerar rendimentos. Essa situação configura uma modalidade de capitalismo dominada pelos "proprietários" (em contraste com os dirigentes da produção) e, portanto, pela renda (no sentido de juros, dividendos, etc.). O "rentista", diferentemente do credor, opera sobretudo nos mercados secundários - onde circulam ativos já emitidos - e embolsa dividendos ou lucros especulativos derivados de seus títulos. Não há preocupação

\footnotetext{
${ }^{548} \mathrm{E}$ o poder que a finança acabou adquirindo sobre o processo produtivo abre inclusive a possibilidade de os recursos continuarem a ser desviados da produção mesmo que não seja mais como estratégia para contornar a sobreacumulação.

${ }^{549}$ Cf. CHESNAIS, "États rentiers dominants et contraction tendencielle (...)”, pp. 101-103.

${ }^{550}$ Deve-se considerar a possibilidade desse balanço ser um pouco exagerado, pois Chesnais em geral trabalha com dados sobre os países centrais (OCDE), de modo que certos diagnósticos, tais como o de baixa acumulação, talvez não possam ser igualmente aplicados sem ressalvas ou adaptações a países do Terceiro Mundo. É preciso também ter cautela sobre o grau de "atonia" da produção, pois o peso da punção da finança pode muitas vezes recair mais sobre o trabalhador (aumentando-se a exploração) do que sobre o lucro/crescimento da empresa.

${ }^{551}$ PAULANI e ALMEIDA FILHO, "Regulação e social e acumulação por espoliação (...)", p. 6.
} 
efetiva com o empreendimento no qual estão aplicando ou com as necessidades de produção, mas apenas com a liquidez dos mercados financeiros.

O rentismo adquire, assim, uma dimensão ampla, permeando diversas relações: “A propriedade patrimonial cria direitos e rendimentos sob a forma de aluguéis, de rendas do solo, de juros e de fluxos relacionados às aplicações em Bolsa, provenham eles de dividendos, de mais valias bursáteis ou da especulação" ${ }^{, 52}$. De modo que o sentido subjacente a isso é o de "tomar o 'capitalismo patrimonial' como sendo inteiramente direcionado para transformar dinheiro, de 'ativo líquido', em um valor que 'produz"”,553.

A espoliação, por sua vez, tal como definida por Harvey, possui maior abrangência e pode ser compreendida como aqueles mecanismos que realizam centralização de capital por meio da absorção de riqueza "extra"-produção (formações sociais não-capitalistas, privatizações, etc.), mas também do "pós"-produção capitalista - como é o caso do rentismo, que se baseia fundamentalmente nos resultados diretos ou indiretos da produção: por um lado, na punção sobre salários (advindos de crédito pessoal, dívida pública, etc.), por outro, na apropriação de parte da mais-valia - seja ela diretamente resultante, como nos dividendos/juros, ou previamente acumulada (caixa da empresa), como no caso de ganhos especulativos na Bolsa. Portanto, a espoliação via finança representa uma expansão do capitalismo para outros lugares e setores, mas também sobre si próprio, de certo modo "alimentando-se" de si mesmo. Em grande medida, o que ocorre nos mercados financeiros é uma "autofagia" do capitalismo (resultando em centralização de capital), estéril para a criação de riqueza do ponto de vista social.

Enquanto a espoliação em geral se realiza fora dos circuitos diretos de valorização do capital e apela a métodos não econômicos, legais e ilegais (sem recusar inclusive o uso da violência), o rentismo pode ser considerado uma modalidade específica de espoliação: rotinizada, legalizada e normalmente intermediada pelos circuitos de valorização financeira do capital $^{554}$. Nesse sentido, o capital financeiro se situa nessa fronteira entre rentismo e espoliação, entre apropriação via circulação do capital e para além dela. Enquanto Chesnais

\footnotetext{
552 PAULANI e ALMEIDA FILHO, "Regulação e social e acumulação por espoliação (...)”, p. 6.

${ }^{553}$ Ibidem, p. 6.

${ }^{554}$ É interessante reproduzir aqui o comentário de Marx - lembrado por Chesnais - a respeito dos títulos financeiros, que concebe explicitamente o rentismo como uma forma substituta da acumulação primitiva ("violência direta") - ou melhor, outra forma desta: "Ganhar e perder pelas flutuações de preço desses títulos de propriedade, bem como sua centralização nas mãos dos reis das ferrovias etc., torna-se virtualmente mais e mais resultado do jogo, que toma o lugar do trabalho, como o modo original de adquirir propriedade do capital, e também o lugar da violência direta” - MARX, O Capital, Livro III (tomo V), cap. 30, p. 20.
} 
destaca as instituições, processos e modo de funcionamento envolvidos na valorização do capital financeiro, Harvey acentua seu caráter predatório, fraudulento, destrutivo e até manifestamente criminoso 555 .

Essa situação adiciona novas contradições ao capitalismo, além de desempenhar um papel chave na dinâmica política. A realocação da riqueza social fora dos processos produtivos, por exemplo, ganha enorme importância, tornando mais complexas as relações de exploração - que não se restringem somente à relação capitalista industrial e trabalhador, mas passam cada vez mais por uma rede de rentistas que se torna maior e mais poderosa, abarcando inclusive trabalhadores.

A respeito disso, como ressalta Chesnais, ao longo de anos o pagamento de aposentadorias privadas (que não deixa de ser um tipo de rentismo) se baseou em taxas de juros reais positivas. Estas estão na origem do crescimento em "bola-de-neve" da dívida pública (ou seja, alimenta outro tipo de rentismo), que por sua vez é a justificativa para o desmonte dos sistemas públicos de proteção social (inclusive de aposentadoria) ${ }^{556}$.

Desse modo, por trás do crescimento da esfera financeira e do aumento espantoso das transações financeiras está, evidentemente, um setor industrial que se expande, se concentra e, portanto, continua sendo a fonte de valorização. Porém, por outro lado, encontra-se igualmente um capitalismo que esbarra em seus próprios limites, que vê sua própria capacidade de expansão e de acumulação fragilizadas por suas contradições. O rentismo e a espoliação, para além de serem instrumentos de exploração e dominação da burguesia, são tentativas de se responder a esses limites. A "recaída" "557 nos expedientes bárbaros da acumulação primitiva, assim como a revitalização de mecanismos de obtenção de mais-valia absoluta, tornam-se então uma necessidade do capitalismo atual.

Assim, fonte do "rentismo" analisado por Chesnais e elemento central da "espoliação" comentada por Harvey, a financeirização constitui um ponto em comum entre esses autores: "aqui, pois, encontramos o ponto de contato mais forte entre as análises de Chesnais e Harvey: a percepção comum quanto à força da financeirização no processo contemporâneo de acumulação do capital” ${ }^{, 558}$. Por outro lado, Paulani e Almeida Filho apontam uma diferença na

\footnotetext{
${ }^{555} \mathrm{O}$ documentário recentemente realizado Inside $\mathrm{Job}$ ilustra a fragilidade da fronteira entre lícito e ilícito nos mercados financeiros. Para uma análise do filme, que aponta também seus limites críticos, ver PAULANI, "Resenha de Inside Job".

${ }^{556}$ Cf. CHESNAIS, "États rentiers dominants et contraction tendencielle (...)”, p. 108.

${ }^{557}$ Entre aspas, pois o capitalismo nunca abandonou de fato esses procedimentos.

${ }^{558}$ PAULANI e ALMEIDA FILHO, "Regulação e social e acumulação por espoliação (...)”, p. 12.
} 
importância conferida por cada autor à financeirização - derivada, como já sugerido, de suas respectivas compreensões do fenômeno -, a saber:

Harvey apreende a influência do capital financeiro sobre o processo de acumulação, porém não o faz com a radicalidade de Chesnais, que virtualmente o toma como um processo inovador, capaz de alterar a essência mesma do processo de acumulação de capital. Ao contrário, Harvey sustenta que, no capitalismo atual, o processo de financeirização aprimora e aprofunda uma característica que seria constitutiva do capitalismo, qual seja, sua tendência a espoliar. ${ }^{559}$

Se o capitalismo possui, portanto, essa "tendência a espoliar", deve-se tomar cuidado com certas análises a respeito da financeirização que a compreendem como uma "anomalia" do capitalismo. Michel Husson faz o seguinte alerta:

Tudo que transforme uma contradição derivada (a financeirização) em contradição principal corre o risco de se desviar do conteúdo anti-capitalista presente em todo combate firme pelo emprego em direção a vãos projetos visando aliviar o capital do peso da finança, a fim de restituir-lhe seu núcleo virtuoso. ${ }^{560}$

O comentário de Husson refere-se, em grande medida, à sua crítica de determinada visão da financeirização, por ele denominada de "parasitismo da finança". Seu ponto principal é exatamente que a financeirização surge do próprio desenvolvimento do capitalismo e que, portanto, não haveria um parasitismo (disfuncional) da finança sobre a produção ${ }^{561}$.

Contudo, parece que a questão pode ser entendida com mais acuidade por meio de um raciocínio dialético. Do contrário, corre-se o risco de cair no funcionalismo, como se todo fenômeno do capitalismo servisse inteiramente a algum propósito. Nesse sentido, a financeirização representa sim determinado obstáculo à valorização do capital $^{562}$ e por isso

${ }^{559}$ PAULANI e ALMEIDA FILHO, "Regulação e social e acumulação por espoliação (...)”, p. 21.

${ }^{560}$ HUSSON, "Finance, hyper-concurrence et reproduction du capital", p. 245.

${ }^{561}$ Sua explicação sobre a diferença observada entre a taxa de lucro e a taxa de acumulação, entretanto, não é muito clara, e estaria ligada sobretudo ao consumo dos rentistas. De qualquer modo, sua visão se baseia também na questão da exploração: "Reencontramos, pois, a idéia de que não é possível dissociar os fenômenos da exploração e da financeirização, que aparecem como dois componentes de uma mesma realidade. O capitalismo contemporâneo é, antes de tudo, um capitalismo super-explorador" - HUSSON, "Finance, hyper-concurrence et reproduction du capital", p. 244.

${ }^{562} \mathrm{O}$ próprio Husson mostra que nas últimas décadas a taxa de lucro tem sido maior que a taxa de acumulação do capital, exatamente porque parte da mais-valia não é reinvestida na produção. Aliás, ele fornece dados sobre a 
mesmo acrescenta e aprofunda as contradições do capitalismo. Por outro lado, a financeirização não é um fenômeno aberrante, mas produto da própria dinâmica do capital, representando assim, como define Husson, a elevação do capitalismo a um "funcionamento "puro", a uma "expressão 'pura' de suas contradições"563.

Trata-se da mesma idéia de Chesnais acerca do "capital em geral”. A financeirização representa a realização do impulso do capital a se tornar um valor em processo, que de fato se “autovaloriza". É como se ele assumisse sua forma mais adequada, embora (ou por isso) esta seja também a mais contraditória. Portanto, a punção da finança sobre a mais-valia representa a forma necessária de circulação do valor produzido para que esse "capital em geral” possa operar na modalidade de "funcionamento puro", ainda que produzindo efeitos negativos sobre a acumulação real do capital industrial.

Desse modo, o caráter destrutivo e espoliativo que o capital assume atualmente, sobretudo na sua forma financeira, guarda relação com a natureza contraditória das respostas que vêm sendo dadas à questão dos problemas de acumulação de capital ${ }^{564}$. Se, como afirma Marx e ressalta Chesnais, o capitalismo supera suas barreiras somente para elevá-las a um grau superior, e se o capital portador de juros e sua derivação fictícia são as formas mais desenvolvidas do capital ${ }^{565}$, é difícil vislumbrar para que direção o capitalismo caminha ${ }^{566}$.

Donde a necessidade, pois, de intensificação das pressões sobre os trabalhadores, tanto do ponto de vista do processo de trabalho em si, inúmeras vezes ressaltado, como da incorporação da ciência ao processo produtivo e, com isso, da subsunção intelectual do trabalhador. Uma vez que o capitalismo se organiza como um processo contínuo e progressivo de privatização e de subordinação de tudo à sua lógica, a transformação da

França que vão do final do século XIX até o início do século XXI e mostra que, até 1980, as duas taxas se movimentavam juntas (quando uma subia/descia a outra também subia/descia), quando então a taxa de lucro se eleva muito, enquanto a de acumulação diminui, criando uma divergência inédita entre ambas. Mais impressionantes são os efeitos disso: desde 1980 a taxa de desemprego acompanha de perto a taxa da financeirização (entendida como a taxa de lucro não reinvestida) no agregado dos países da União Européia. Cf. HUSSON, "Finance, hyper-concurrence et reproduction du capital", pp. 224 e 239.

${ }^{563}$ Ibidem, p. 245.

${ }^{564}$ Cabe ressaltar que a insaciabilidade das punções da finança sobre a produção se converte em grande estímulo à prática da acumulação por espoliação.

${ }^{565}$ Em sua obra, Marx não levou seu desenvolvimento categorial do capital além dessas formas, que para ele são as mais fetichistas e alienadas.

${ }^{566}$ A esse respeito, análises tão diferentes quanto a de Chesnais e de Prado parecem identificar, cada um a seu modo, esse paroxismo da contradição do capital no capitalismo contemporâneo. Para Chesnais a financeirização representa de certa forma o solapamento, pelo próprio desenvolvimento do capital, das condições de acumulação (baixa acumulação). Já Eleutério identifica na pós-grande indústria - subsunção intelectual do trabalhador ao capital e penetração da ciência no processo produtivo - a auto-negação incipiente da teoria do valor (desmedida do valor). 
ciência em elemento fundamental do processo de valorização do capital é apenas a etapa mais recente disso: um novo âmbito da ação humana é posto sob os constrangimentos da propriedade privada e a serviço do capital.

As conseqüências desses processos são múltiplas. Chesnais menciona algumas delas ${ }^{567}$ sem, contudo, deter-se mais demoradamente. Pierre Salama ${ }^{568}$ aponta alguns dos impactos específicos da financeirização nas economias do Terceiro Mundo. Ele destaca, por exemplo, o caráter excludente da mundialização financeira: 66\% do IED da OCDE em África, América Latina e Ásia estão concentrados em 20 países. Ressalta ainda que, para atrair esse fluxo de capitais, a elevação da taxa de juros é uma condição necessária, mas não suficiente. Além disso, sua contrapartida é pesada: a elevação dos juros amplia a vulnerabilidade dos bancos, ao reduzir o valor de seus ativos, o que os incentiva a conceder créditos imprudentes, aumentando o risco de calote. Paralelamente, eleva-se o custo dos empréstimos e aumenta o déficit orçamentário, sem que a redução das despesas públicas seja suficiente para contrabalançá-lo. As empresas então revêem para baixo seus investimentos, tanto por conta dos custos mais elevados como pela arbitração em favor da compra de títulos da dívida pública. A conseqüência é um ciclo recessivo vicioso: a alta dos juros agrava as dificuldades orçamentárias e aprofunda a recessão, o que conduz a nova alta dos juros e à desvalorização da taxa de câmbio.

Harvey, por sua vez, apresenta contribuições importantes referente às mudanças culturais e políticas. Dentre estas, o foco recai muitas vezes sobre a transformação do papel do Estado (no sentido da neoliberalização e de um tipo específico de imperialismo). Mas ele menciona também as formas de resistência e de lutas políticas contra o capital ${ }^{569}$, que classifica em dois tipos gerais. De um lado, os movimentos socialistas "tradicionais", baseados na organização do proletariado, nos partidos e nos sindicatos, com o objetivo de tomar o Estado para suplantar o domínio da classe capitalista. Ou seja, combates concentrados nas "relações de classe e [n]as lutas de classes no campo da acumulação do capital, entendida como reprodução expandida" ${ }^{\text {570 }}$ e que de alguma forma se enfraqueceram a partir dos anos 1970 com a virada neoliberal. De outro lado, surgem movimentos - em parte devido às

\footnotetext{
567 Chesnais chega a mencionar de passagem a "acumulação por espoliação" de Harvey, em uma das poucas alusões feitas a este autor. Cf. CHESNAIS, "La prééminence de la finance (...)", p. 66.

568 Cf. SALAMA e CAMARA, "A inserção diferenciada - com efeitos paradoxais - dos países em desenvolvimento na mundialização financeira".

${ }^{569}$ HARVEY, "O novo imperialismo", cap. 4.

${ }^{570}$ Ibidem, p. 139.
} 
próprias omissões dos movimentos tradicionais em relação a certas lutas - de contestação direta à acumulação por espoliação, de caráter tão diversificado quantas são as formas desta. Eles podem atuar em escala local, regional ou global, ter como bandeira a questão ecológica, alternativas à globalização, o acesso à terra ou permanência nela, a recusa de privatizações ou de construções que degradem as condições de vida de certas populações, etc. ${ }^{571}$

Pela própria natureza da financeirização, o combate a ela pode (e tende a) ser encampado por ambos os tipos de movimento. Ela diz respeito tanto à luta de classes no âmbito da reprodução ampliada - já que impacta os circuitos de valorização do capital e as condições de trabalho e de vida dos trabalhadores enquanto tais; como também à dinâmica da acumulação por espoliação - uma vez que a ação predatória do capital financeiro contribui para a degradação das condições de existência de populações e de grupos que muitas vezes se encontram longe dos grandes centros de acumulação de capital.

Talvez por essa razão, a luta da maior parte desses grupos passe pela questão da financeirização (sobretudo os anti-globalização/anti-neoliberalismo), embora não haja muitos movimentos que adotem especificamente como bandeira o combate ao capital financeiro ${ }^{572}$. E isso tem sua razão de ser, pois em certo sentido vale a idéia contida na expressão de Husson: "a finança é 'a árvore que esconde a floresta", ${ }^{273}$. Se a financeirização decorre do próprio desenvolvimento do capitalismo e se o sistema de crédito constitui um aspecto fundamental no funcionamento deste, parece não fazer sentido tornar a finança em si o objeto principal de contestação. Um movimento anti-financeirização "stricto sensu" não seria mais que uma tentativa de harmonizar as contradições do capitalismo atacando os "sintomas" ou fenômenos superficiais, cujas conseqüências podem ser inclusive ruins, tais como a geração ou intensificação do desemprego, do empobrecimento, da desaceleração econômica, etc.

Por outro lado, se a financeirização constitui um elemento decisivo da conformação do capitalismo contemporâneo, e não um desvio em seu desenvolvimento ou detalhe a ser corrigido por meio de medidas de controle, uma compreensão correta de seu significado pode justificar o combate a essa modalidade como uma contestação do capitalismo em geral. Desde que cônscios disso, movimentos "anti-financeirização" podem ser importantes politicamente

\footnotetext{
571 Recentemente há o exemplo do Equador, que revisou sua dívida pública e das mobilizações pela "desprivatização" da água na Bolívia.

572 A notável exceção é a ATTAC (Association pour la Taxation des Transactions financières pour l'Aide aux Citoyens [Associação pela taxação das transações financeiras em auxílio aos cidadãos]), da qual Chesnais é membro importante.

${ }^{573}$ HUSSON, "Finance, hyper-concurrence et reproduction du capital", p. 221.
} 
para iniciar ações contestatórias mais amplas ${ }^{574}$. Assim, contestar a financeirização (bem como o neoliberalismo e o imperialismo) ou o capitalismo em geral não são alternativas mutuamente excludentes, mas podem ser dimensões distintas de um mesmo combate ${ }^{575}$. Reconhecer, pois, que a financeirização é uma forma de capitalismo - um modo de sua organização que provavelmente piorou as condições de vida de grandes parcelas da população mundial em relação às décadas precedentes - e lutar contra ela não significa necessariamente eleger outra forma de capitalismo como preferível, ao contrário.

Desde que os efeitos da crise de 2008 começaram a ser sentidos, são visíveis as reações populares suscitadas pelo caráter espoliativo e fraudulento do capital financeiro, responsável pela degradação das condições de vida de milhões de pessoas inclusive nos países centrais do capitalismo. Embora ainda seja prematuro dizer até que ponto tais contestações e reivindicações obterão êxito, uma coisa parece certa: a crise mostrou ser um momento privilegiado para reações sociais, em grande medida por tornar mais nítida a lógica de funcionamento do capitalismo, tornando o fetichismo menos opaco. Embora essa tomada de consciência seja limitada e os trabalhadores se encontrem em muitos aspectos fragilizados durante a crise, emerge a possibilidade de se engendrarem mobilizações mais radicais, que contestem o próprio capitalismo.

Nesse sentido, cabe observar que se a acumulação por espoliação é um mecanismo poderoso por centralizar muita riqueza em pouco tempo, ela possui certa fragilidade do ponto de vista ideológico. Ao recorrer ao Estado e às instituições políticas, utilizando-se muitas vezes de meios não legitimados socialmente, ela demanda muitas vezes uma justificação mais

\footnotetext{
${ }^{574}$ Em sua defesa da taxa Tobin, Chesnais argumenta que ela tem um impacto menor à mundialização financeira do que outras medidas. No entanto, ela pode ser o início de uma mobilização em um cenário político tão recuado como o atual, em que não se admite qualquer questionamento do capital financeiro. Chesnais ressalta o caráter educativo da taxa Tobin e sua capacidade de promover o debate e de colocar em questão "o caráter sistêmico do processo de mundialização dos mercados financeiros, bem como os fundamentos rentistas dos mecanismos de apropriação e de transferência internacional do valor e da riqueza" - CHESNAIS, Tobin or not Tobin?, p. 15.

575 Pode-se pensar numa analogia com a questão clássica de reforma versus revolução. Limitar-se a reformas pontuais sem um sentido maior de revolucionar pode ser tão equivocado quanto pregar uma revolução abstrata e sem mediações. A composição de reformas com um intuito revolucionário subjacente parece ser uma proposta geralmente mais adequada. Desse modo, lutar contra o capitalismo de forma abstrata, sem levar em conta sua conformação específica atual, pode ser equivocado politicamente, inclusive no sentido mais pragmático de reunir pessoas e angariar apoio.
} 
complexa. Ela não se beneficia tanto do fetichismo que vela os processos moleculares da acumulação - encobertos pela ideologia arraigada da troca entre iguais, do direto à propriedade privada, da liberdade de contrato, etc. $\mathrm{O}$ episódio analisado por Harvey em $O$ novo imperialismo, a Guerra do Iraque, ilustra isso: ela demandou todo um discurso sobre segurança nacional/internacional e exportação da democracia, a costura de alianças com diversos países, além de falsificação de provas para a manipulação da opinião pública. Atualmente, vêem-se também protestos daqueles que perderam suas casas, suas poupanças, seus empregos por causa de malabarismos financeiros, inclusive fraudulentos, dos quais poucos conheciam a existência.

Por isso, embora o capital financeiro - enquanto processo econômico "tout court" - se beneficie em certos momentos das justificativas propiciadas pela ideologia burguesa, ele demonstra uma fragilidade, na medida em que opere por meio de mecanismos abertamente espoliativos. Quando eclodem grandes crises financeiras, sua face espoliativa, fraudulenta e violenta vem à tona e os protestos aparecem. Nesses momentos torna-se mais visível a relação entre esse aspecto do capital financeiro e a base mais profunda da exploração capitalista.

Uma vez que não é possível prever o que sucederá ao capitalismo atual, pode-se tentar estabelecer, sem entrar em detalhes, algumas opções baseadas em processos anteriores. No curto e talvez médio prazos, o mais provável é que o capitalismo mantenha sua atual fragilidade sistêmica, sendo acometido de crises mais ou menos recorrentes e intensas. Nesse cenário, ainda é preciso levar em conta dois obstáculos com os quais o capitalismo se defrontará: a crise ecológica - que se coloca como uma espécie de barreira absoluta - e a impossibilidade "formal" de um desenvolvimento superior do capital - para além do capital portador de juros e do capital fictício.

Dada a rapidez e força da resposta à grave crise de 2008, a famosa "crise final do capitalismo" não parece estar no horizonte. Até porque para que ela se concretize não basta um processo econômico, este precisa ser acompanhado de uma movimentação política radical e forte, capaz de colocar em xeque a ordem capitalista como um todo. Outra opção é que uma grave crise (que aparentemente precisaria eclodir em breve, antes do capitalismo se recuperar da crise de 2008, ou ser ainda mais profunda que esta) ou uma guerra de grandes proporções possam ocasionar a destruição necessária para colapsar a atual dinâmica e retomar a acumulação de capital em outras bases, tal como foi a combinação da Crise de 29 e da Segunda Guerra Mundial no passado. 


\section{ANEXO 1 - BREVES NOTAS SOBRE O REGIME DE ACUMULAÇÃO FORDISTA}

Dentre os diversos conceitos que a escola francesa da regulação cunhou a fim de caracterizar com mais precisão as fases do capitalismo ${ }^{576}$, um dos mais importantes foi empregado tanto por Harvey quanto por Chesnais: o de "regime de acumulação". Nesse sentido, como o "regime de acumulação com dominância financeira", de Chesnais, e o "regime 'flexível' de acumulação", de Harvey, em muitos aspectos são definidos em contraste com o regime de acumulação precedente - o fordismo - é apresentada aqui uma breve descrição deste. Trata-se de uma exposição esquemática, inspirada nos conceitos da escola da regulação.

Cabe esclarecer, portanto, que não estarão contempladas as diferentes nuances teóricas existentes no seio da escola da regulação acerca de uma realidade tão complexa e contraditória como o fordismo. Além disso, existiram clivagens no seio da classe trabalhadora dos países centrais e formas "periféricas" do fordismo, o que dificulta uma apreensão geral do capitalismo dos "Anos de Ouro". Desse modo, ressalta-se que o fordismo tal como é geralmente descrito - não só por regulacionistas, mas também por Chesnais e Harvey em algumas passagens - foi uma realidade histórica parcial e relativamente circunscrita, inclusive temporalmente (1945-1975, como se convencionou periodizar) e geograficamente (sua forma "clássica” restringindo-se normalmente a países centrais do capitalismo).

No que se refere especificamente ao regime de acumulação fordista, ressalta-se a acumulação intensiva de capital como forma dominante. O desenvolvimento tecnológico, aliado ao taylorismo (entendido como técnica de organização do trabalho), leva a um tipo de produção centrada na extração de mais valia relativa e, portanto, no crescimento da produtividade. Apesar da tendência imanente do capital à aceleração de sua rotação, o longo prazo é predominante como parâmetro para os princípios de gestão. De forma a escoar o incremento de produtividade, o sistema baseia-se no consumo de massas e na relativa

\footnotetext{
${ }^{576}$ Para uma sistematização dos conceitos regulacionistas consultar, por exemplo: BOYER, A teoria da regulação e BRUNO, Crescimento econômico, mudanças estruturais e distribuição. Para uma análise crítica dessa corrente de pensamento: BRAGA, A nostalgia do fordismo - elementos para uma crítica da Teoria Francesa da Regulação.
} 
padronização das mercadorias. Trata-se de um período em que os trabalhadores assalariados tiveram, em geral, ganhos reais de renda (padrão progressivo de distribuição de renda) e em que havia "solidariedade" entre atividades financeiras e produção, ou seja, os investimentos financeiros fomentavam preferencialmente o incremento da produção de mercadorias ${ }^{577}$.

Quanto à regulação vigente, é impossível descrevê-la exaustivamente, mas pode-se defini-la como um modo de regulação "monopolista de Estado". As políticas keynesianas de estímulo ao investimento e à demanda agregada definem um Estado ativo na economia. A partir deste, surge uma conformação chamada de estado do bem-estar social, amparada por diversos compromissos de classes. Ênfase é dada na moeda enquanto bem público e não como meio de negociação e especulação. Grandes empresas se internacionalizam e dominam processos inteiros de produção (centralização vertical), mas o referencial em termos de regulação continua sendo o Estado-Nação.

Sobre a relação de trabalho, predomina o trabalho formal (assalariado) com a busca do pleno emprego. As diversas formas de salário indireto decorrentes da conquista de direitos trabalhistas e sociais ganham importância. A organização fordista-taylorista do trabalho, aliada à conquista de direitos, leva a uma relativa estabilidade social, como reconhece o próprio Chesnais: “O sistema soube gerar (...) um nível de emprego assalariado suficientemente alto e suficientemente bem pago para preencher as condições de estabilidade social e, ao mesmo tempo, criar os traços necessários à produção de massa"578. Harvey também se surpreende com a maneira pela qual governos criaram "tanto um crescimento econômico estável como um aumento dos padrões materiais de vida através de uma combinação de estado do bem-estar social, administração econômica keynesiana e controle das relações de salário" ${ }^{579}$, criando um equilíbrio de poder, ainda que tenso, entre trabalho, capital e Estado.

No que se refere ao capital, predomina sua forma industrial, ou seja, a produção efetiva de bens. As empresas multinacionais se desenvolvem, ainda que com ligações fortes com seus países de origem (matrizes), e são amparadas por Estados voltados para o crescimento econômico. Por outro lado, estes, ao se preocuparem também com o welfare,

\footnotetext{
577 "O núcleo do modo de regulação [fordista] era a conciliação entre rápidos ganhos de produtividade e o crescimento da renda real, com a estabilidade em sua distribuição”, AGLIETTA, A Theory of Capitalist Regulation, p. 407.

${ }^{578}$ CHESNAIS, A mundialização do capital, p. 300.

${ }^{579}$ HARVEY, Condição pós-moderna, p. 130.
} 
limitavam (pelo menos relativamente) o capital privado e ofereciam garantias sociais. Havia, assim:

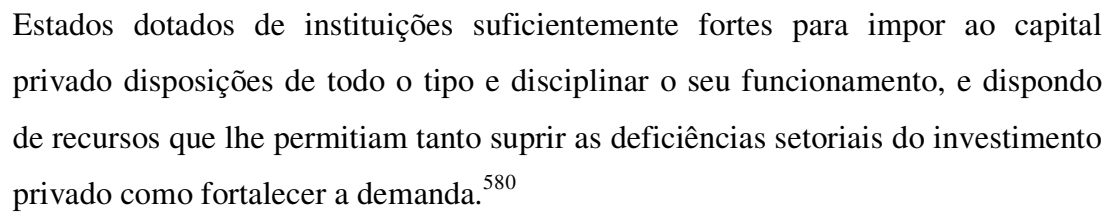

O sistema monetário vigente durante o fordismo foi baseado na moeda de crédito, sob o domínio do padrão dólar-ouro, portanto já sob hegemonia norte-americana, mas com moedas nacionais soberanas. As operações financeiras eram intermediadas (o sistema bancário era fundamental), administradas (havia controles estritos sobre o movimento de capitais por parte dos Estados) e industrializantes (como foi dito, eram destinadas a fomentar a produção). Os Estados controlavam a taxa de juros, buscavam manter a inflação em patamares baixos e mantinham as taxas de câmbio fixas ${ }^{581}$. As operações de câmbio destinavam-se prioritariamente a viabilizar exportações e importações e não à especulação em mercados financeiros. Dessa forma, vigia um "ambiente monetário internacional estável" ${ }^{, 582}$.

Nesse contexto, o regime internacional como um todo funcionava a partir de Estados nacionais dotados de relativa autonomia em comparação com o contexto atual. As economias, em boa parte devido às finanças administradas, eram mais fechadas, de modo que a dinâmica mundial era resultado da articulação das dinâmicas nacionais. Existiam movimentos de internacionalização e empresas multinacionais, mas não o grau de abertura e de fluxos de capital entre países encontrado no que hoje se chama de "globalização".

A percepção de grande estabilidade e regularidade de desenvolvimento - talvez inéditas na história do capitalismo, mas exageradas em alguns aspectos -, com mecanismos contra-cíclicos eficazes, durante a vigência do fordismo se traduz na seguinte proposição de Boyer $^{583}$ :

\footnotetext{
${ }^{580}$ CHESNAIS, A mundialização do capital, p. 300.

581 Embora parte das tensões econômicas fosse resolvida através da emissão monetária e da inflação. Cf.CHESNAIS, "Mundialização financeira e vulnerabilidade sistêmica", p. 260.

${ }^{582}$ CHESNAIS, A mundialização do capital, p. 300.

583 A descrição que segue, embora talvez excessivamente otimista, de alguma forma condiz com a visão de Harvey sobre o fordismo-keynesianismo. Para este, o fordismo conseguiu evitar por muito tempo que a sobreacumulação se tornasse um problema grave, por meio, entre outras coisas, das estratégias de ajustes espaçotemporais (ver Parte II).
} 
Os 'trinta gloriosos' são vistos como o primeiro exemplo de uma evolução rápida e razoavelmente sincronizada das normas de produção e de consumo, evitando transformar a sobreacumulação num risco tendencial e a recorrência de depressões no único meio de ajustamento. ${ }^{584}$

${ }^{584}$ BOYER, A teoria da regulação, p. 120. 


\section{ANEXO 2 - TERMOS E CONCEITOS}

Uma apresentação dos conceitos e noções fundamentais de Marx sobre o capital financeiro $^{585}$ é importante, uma vez que são o ponto de partida de Chesnais e de Harvey e o elemento fundamental de articulação entre eles. Não se trata de uma exegese do que Marx expôs na seção V do livro III de $O$ Capital (núcleo das bases conceituais para o entendimento do assunto), mas apenas de uma exposição introdutória. Mesmo porque, em muitos momentos, Chesnais e Harvey retomam de perto esse texto ${ }^{586}$.

Os conceitos seminais criados por Marx que permitem tratar da esfera financeira são o de "capital portador de juros" e de "capital fictício" (daquele derivado). Estes corresponderiam, segundo ele ${ }^{587}$, às formas mais fetichistas do capital, à sua forma mais alienada.

O capital portador de juros, normalmente existente na forma monetária ${ }^{588}$, é uma soma de valor que é posta para circular, "para si" e "para outros" ${ }^{\text {"59 }}$, como capital - e que, portanto, deve por definição valorizar-se. Dito de outra forma, trata-se de uma quantia de dinheiro que não se torna capital somente para o produtor de mercadorias nem só quando é transformado em força de trabalho e meios de produção para iniciar um ciclo produtivo. Ela já é capital quando sai das mãos de seu dono (o prestamista) na medida em que deve imperativamente retornar a ele acrescida de juros. Desse modo, sendo uma fração da mais-valia produzida ${ }^{590}$, o juro só será gerado caso o capital seja efetivamente empregado na produção de mercadorias pelo tomador do empréstimo. Nesse sentido, a forma aparente que corresponde à valorização do capital portador de juros D-D' não passa da simplificação mistificadora do movimento real de valorização do capital: D-[D-M...P...M'-D']-D', que materialmente não difere do movimento de qualquer capital que se valoriza produtivamente. A intermediação da

\footnotetext{
${ }^{585}$ Na realidade, Marx não usa o conceito de capital financeiro. Este é definido e largamente utilizado por Rudolf Hilferding em seu livro $O$ capital financeiro. Marx trata da circulação do capital monetário, visando à sua autovalorização, sob a noção de "capital portador de juros".

${ }^{586}$ No livro La finance capitaliste, por exemplo, Chesnais retoma quase que capítulo por capítulo a seção V.

${ }^{587}$ Cf. MARX, O Capital, Livro III (tomo IV), cap. 24, p. 293.

588 "Normalmente" na forma monetária, pois Marx deixa claro que o elemento definidor do capital portador de juros é a forma pela qual ele é colocado para se valorizar. Consequentemente, mesmo se ele for emprestado na forma mercadoria, isso em nada altera seu caráter - Cf. Ibidem, cap. 21.

${ }^{589}$ Cf. Ibidem, cap. 21 , pp. 258 e 259.

${ }^{590}$ Cf. Ibidem, cap. 21 e 22.
} 
mercadoria para a valorização do valor parece, então, deixar de ser necessária, donde a possível aparência de uma autonomização da esfera financeira em relação à base material.

Quanto ao capital fictício, ele é uma derivação do capital portador de juros, tanto que Marx aborda-os conjuntamente e não como duas formas distintas do capital (como é o caso do capital industrial, do capital comercial, etc.). Contudo, a definição do capital fíctício já não é tão clara, como sugerem Nakatani e Herrera:

A categoria capital fictício está pouco elaborada no livro III d’O Capital de Marx, que foi organizado e editado por Friedrich Engels. Não há, no livro III, uma única definição de capital fictício, o que existem são pistas e desenvolvimentos das diversas possibilidades da evolução, ou das formas que podem ser assumidas, do capital portador de juros. ${ }^{591}$

Por outro lado, há indicações suficientes sobre o capital fictício para que se façam diversos desenvolvimentos do conceito. Além disso, a lacuna na sua definição pode não ser somente devida ao caráter inacabado da obra de Marx. As múltiplas (talvez incontáveis) formas que ele pode assumir talvez dificultem mesmo uma definição precisa.

Sucintamente, o capital fictício é uma forma do capital portador de juros que não possui base material de valorização (na produção de mercadorias). A primeira fonte de criação de capital fictício é a própria hipertrofia do sistema de crédito ${ }^{592}$ e a conseqüente multiplicação dos meios de pagamento secundários (letras de câmbio, notas promissórias, etc.). Marx fornece alguns exemplos, como do comércio entre a Inglaterra e suas colônias. A demora no transporte das mercadorias permitia que os meios de pagamento secundários fossem duplicados nas duas pontas e usados em inúmeras outras transações antes de serem efetivamente liquidados com a chegada da mercadoria (ou renovados por operações subseqüentes $)^{593}$. Esse tipo de operação coloca em circulação uma quantidade de valor superior ao contido nas mercadorias produzidas. Esse componente do capital bancário (que abrange também as outras duas formas do capital fictício expostas adiante), constitui, assim, uma das modalidades de capital fictício analisadas por Marx.

Com as bolsas de valores e as sociedades por ações, surge outra forma do capital fictício: as ações de empresas. Se, a princípio, elas corresponderiam a uma fração do capital real da empresa, ganham, no interior da Bolsa, uma espécie de "segunda vida". Ocorre uma

\footnotetext{
${ }^{591}$ NAKATANI e HERRERA, Crise financeira... ou de superprodução?, p. 2.

${ }^{592}$ Ela possibilita uma alavancagem maior da economia, mas, em contrapartida, aumenta os riscos de colapso da cadeia de crédito e, com ela, da economia como um todo.

${ }^{593}$ Cf. MARX, O Capital, Livro III (tomo IV), cap. 25.
} 
duplicação do próprio capital: enquanto o capital efetivo está materializado na produção (na forma de meios de produção e de força de trabalho), sua face fictícia circula no mercado acionário, adquire um preço e está sujeita à especulação. Contudo:

Esse capital não existe duplamente, uma vez como valor-capital dos títulos de propriedade, das ações, e outra vez como capital realmente investido ou a investir naquelas empresas. Ele existe apenas nessa última forma, e a ação nada mais é que um título de propriedade, pro rata, sobre a mais-valia a realizar por aquele capital. $^{594}$

O capital acionário, portanto, também se baseia na apropriação de um valor a ser gerado futuramente, ou seja, numa expectativa de geração de valor.

Do mesmo modo acontece com a dívida pública, a terceira forma de capital fictício mencionada por Marx. Ela se funda na receita futura do Estado, que, por sua vez, é constituída de impostos (frações de mais-valia e de salário). Porém, diferentemente das ações, a dívida pública não é fictícia no sentido de ser uma duplicata de um capital produtivo: ela não é e nunca foi capital ${ }^{595}$. Mais do que isso, além de não ser fruto da aplicação em um empreendimento capitalista, ela pode servir para cobrir um gasto já efetuado pelo Estado. A transformação da dívida pública em "capital” ocorre, assim, por meio de um processo - que na realidade está por trás de toda formação de capital fictício - denominado por Marx de "capitalização" "596. Ele é consequiência da generalização do capital portador de juros pela sociedade: toda soma de dinheiro parece ganhar a propriedade intrínseca de render algum juro, de forma que mesmo o que não é capital parece poder valorizar-se como tal.

Em todos os três casos citados por Marx ${ }^{597}$, esse "capital” que depende de uma produção futura de valor ou da realização futura do valor das mercadorias se constitui em um fator de ampliação do potencial de ocorrência de crises. Quando essa produção de valor não

\footnotetext{
${ }^{594}$ MARX, O Capital, Livro III (tomo V), cap. 29, p. 11.

${ }^{595}$ Embora a dívida pública seja mais diretamente identificável como fictícia, os títulos de dívida e as ações não são menos ilusórios: "Mesmo lá onde o título de dívida - o título de valor - não representa, como no caso das dívidas públicas, um capital puramente ilusório, o valor-capital desse título é puramente ilusório" - MARX, $O$ Capital, Livro III (tomo V), cap. 29, p. 11. Contudo, há autores que levam em conta essa diferença e distinguem dois "tipos" de capital fictício. Ver CARCANHOLO e SABADINI, "Capital fictício e lucros fictícios".

${ }^{596} \mathrm{O}$ processo de capitalização é tratado em mais detalhes no Capítulo 2.

${ }^{597}$ Marx trata a renda da terra em separado, como um tipo de rendimento diferente do lucro e do juro. Contudo, em Limits to Capital, Harvey argumenta que em condições de comércio livre de terras e de um sistema de crédito desenvolvido, ocorre a transição para uma "forma puramente capitalista da propriedade da terra" HARVEY, Limits to Capital, p. 347. A terra não sendo produto do trabalho humano, portanto não sendo um bem que possui valor, e dada a função coordenadora que a renda dela proveniente possui na economia em termos de alocação desse bem, a terra pode, então, ser concebida como um capital fictício, cujo rendimento seria o juro desse capital. Cf. Ibidem, cap. 11.
} 
ocorre como o esperado, o que pode ser uma decorrência da crise ou a sinalização de seu início, há o "acerto de contas" com a realidade. Tal processo pode ser tão intenso a ponto desse "capital" perder todo seu "valor".

"Capital portador de juros", "capital fictício" e "capitalização" são, assim, os conceitos/noções básicos legados por Marx para se compreender a financeirização ${ }^{598}$.

Quanto aos termos e conceitos utilizados pelos diferentes autores aqui tratados, é preciso realizar um breve esclarecimento a fim de evitar confusões. Principalmente em relação a Chesnais, que modifica, ao longo das obras, a nomenclatura empregada, sem grande preocupação em assinalar devidamente ao leitor - o que ainda é agravado pela questão da tradução.

Marx utiliza, sobretudo, os termos:

- "capital monetário" ou "capital-dinheiro" (diferença apenas de tradução): representa uma forma do capital que se opõe a capital-produtivo e a capital-mercadoria;

- "capital bancário": a designação de um tipo específico de capital monetário correspondente aos ativos que o banco possui como capital (em grande parte fictícios);

- "capital portador de juros": diz respeito a um modo de circulação ou função do capital que se opõe à do capital industrial e do capital comercial, por exemplo;

- "capital fictício": uma derivação deste último.

O termo "capital financeiro" foi criado por Hilferding (e aproveitado por Lênin). Trata-se de uma tentativa de teorizar sobre os processos de concentração e monopolização que ocorriam no final do século XIX e início do século XX, principalmente na Alemanha. Ele significa a síntese entre os capitais comercial, industrial e bancário sob o comando deste, no contexto mais amplo do imperialismo ${ }^{599}$. A ênfase parece residir não na forma específica de circulação/valorização do capital como somas de dinheiro que buscam valorização sem deixar a forma monetária (como em Chesnais), mas antes no entrelaçamento dessas formas de

\footnotetext{
${ }^{598}$ Há outros elementos importantes, mas são discutidos ao longo da dissertação.

${ }^{599} \mathrm{Na}$ Parte II, é apresentada a visão de Harvey sobre o conceito, que é concebido sob uma dupla dimensão: um determinado processo de circulação do capital e um bloco de poder no interior da burguesia.
} 
capital, inclusive e principalmente em termo políticos - de aliança entre facções da burguesia. Significa também a aplicação do capital bancário nas atividades produtivas: embora o capital conserve a forma monetária para seus proprietários,

Por outro lado, o banco deve imobilizar uma parte cada vez maior de seus capitais. Torna-se, assim, em proporções cada vez maiores, um capitalista industrial. Chamo de capital financeiro o capital bancário, portanto o capital em forma de dinheiro que, desse modo, é na realidade transformado em capital industrial. ${ }^{600}$

Por um lado, Chesnais adota parte da terminologia de Marx ("capital portador de juros" e "capital fictício") e, por outro, busca ampliar o conceito de "capital financeiro" de Hilferding, a fim de analisar o atual período do capitalismo. Ele emprega preferencialmente a expressão "capital de placement (financier)" (traduzida como "capital financeiro", ou mesmo "capital portador de juros"). A tradução desse termo, bem como seu uso em contextos de um público não-especializado, leva a certas confusões. Quanto a isso, os tradutores de $A$ finança mundializada redigem a seguinte nota:

Traduzimos o termo capital de placement como 'capital portador de juros' [termo de Marx, que em francês seria capital productif/porteur d'intérêt - I.L.] por indicação do autor e pela inadequação do conceito de capital financeiro [provavelmente na acepção de Hilferding, e que em francês seria capital financier I.L.]. O conceito de capital de placement significa mais precisamente uma combinação do capital portador de juros, como é definido por Marx, com o capital fictício, e em seu comportamento predomina o aspecto especulativo e rentista. ${ }^{601}$

Embora seja insuficientemente rigorosa, deixando ainda muitas imprecisões, essa nota revela que para Chesnais o capital financeiro é o capital monetário que busca " "fazer dinheiro' sem sair da esfera financeira" ${ }^{602}$ em suas mais diversas formas (não só penetrando diretamente na indústria, mas também pela dívida do Estado e do salário dos trabalhadores, por exemplo). Ele é representado não mais prioritariamente pelos bancos, mas pelas recentes e poderosas instituições financeiras (fundos de pensão, fundos de investimentos, etc.).

Além disso, o desenvolvimento do raciocínio parece ser oposto ao de Hilferding em um sentido preciso: admite-se, por um lado, que o capital bancário se incorpora ao industrial, mas, por outro, constata-se o movimento de um capital industrial que se torna progressivamente "financeiro".

\footnotetext{
${ }^{600}$ HILFERDING, $O$ capital financeiro, p. 219.

${ }^{601}$ CHESNAIS, A finança mundializada, p. 28, nota dos tradutores.

${ }^{602}$ CHESNAIS, "O capital portador de juros (...)”, p. 35.
} 
À semelhança de Hilferding, há uma dimensão fortemente política, acerca dos interesses e alianças das facções da burguesia, que não está diretamente presente em $O$ Capital. Nesse sentido, o termo "finança", empregado por Chesnais, embora podendo por vezes ser usado como sinônimo de capital financeiro, está associado aos atores políticos, representantes do capital financeiro.

Quanto a Harvey em Limits to Capital, obra na qual trata de forma mais aprofundada as questões do dinheiro, do crédito e do capital financeiro, ele utiliza preferencialmente os termos do próprio Marx - o que é natural, na medida em que está analisando O Capital. Ele faz também uma discussão do "capital financeiro" de Hilferding, criticando-o e apresentando sua própria visão. 


\section{BIBLIOGRAFIA}

\section{Obras de autoria ou organização de François Chesnais:}

CHESNAIS, François. A mundialização do capital. São Paulo: Xamã. 1996 [1994].

[1996] . (org.). A mundialização financeira: gênese, custos e riscos. São Paulo: Xamã. 1998 Artigo citado:

. "Mundialização financeira e vulnerabilidade sistêmica" (Cap. 8, pp. 249-293).

Tobin or not Tobin?. São Paulo: Editora UNESP / ATTAC. 1999.

"États rentiers dominants et contraction tendencielle: Formes contemporaines de l'impérialisme et de la crise”. In: DUMÉNIL, Gérard. LÉVY, Dominique (org.). Le triangle infernal. Crise, mondialisation, financiarisation. Paris: PUF. 1999. pp.95-120.

CHESNAIS et al. Uma nova fase do capitalismo?. São Paulo: Xamã. 2003 [2001].

Artigo citado:

CHESNAIS, F. “A 'nova economia': uma conjuntura própria à potência econômica estadunidense" (Cap. 2, pp. 43-70).

CHESNAIS, F. "La théorie du regime d'accumulation financiarisé: contenu, portée et interrogations". Março/2002. Internet. Acessado em 11/12/2009. http://web.upmfgrenoble.fr/regulation/Forum/Forum_2001/Forumpdf/03_CHESNAIS.pdf

. (org.). A finança mundializada: raízes sociais e políticas, configuração, consequências. São Paulo: Boitempo. 2005 [2004].

Artigos citado:

. “O capital portador de juros: acumulação, internacionalização, efeitos econômicos e políticos" (pp. 35-67).

CHESNAIS, F et al.. La finance capitaliste. Paris: PUF. 2006.

Artigo citado:

CHESNAIS, F. "La prééminence de la finance au sein du 'capital en général', le capital fictif et le mouvement contemporain de mondialisation du capital" (Cap. 2, pp. 65-130). 
CHESNAIS, F. "Fin d'un cycle. Sur la portée et le cheminement de la crise financière". In: $L a$ Brèche/Carré Rouge. $\mathrm{N}^{\circ} 1.1^{\circ}$ trim/2008, pp. 17 a 31.

. "Notes pour la discussion du 8 mars au groupe de travail au Centre de Sociologie européenne". (Texto enviado pelo autor por e-mail pessoal em 11/12/2009).

CHESNAIS, F. BIHR, Alain. "À bas la propriété privée". Le Monde Diplomatique. Out/2003. Internet. Acessado em 20/05/2010. http://www.monde-diplomatique.fr/2003/10/BIHR/10606

\section{Obras de David Harvey:}

HARVEY, David. Condição pós-moderna. 14ª ed. São Paulo: Edições Loyola. 2005 [1991]. . The Condition of Postmodernity. Oxford: Blackwell Publishing. 1990.

. O novo imperialismo. São Paulo: Loyola. 2005 [2003].

. Limits to Capital. London/ New York: Verso. 2006 (1 ${ }^{\text {a }}$ ed. de 1982).

. O neoliberalismo: história e implicações. São Paulo: Edições Loyola. 2008 [2005].

. “O ajuste espacial: Hegel, Von Thünen e Marx”. [1981] In: Produção

capitalista do espaço. São Paulo: Annablume. 2006.

\section{Demais referências:}

AGLIETTA, Michel. A Theory of Capitalist Regulation. London/New York: Verso. 2000 [1987].

ANDERSON, Perry. As origens da pós-modernidade. Rio de Janeiro: Jorge Zahar. 1999.

ARRIGHI, Giovanni. O longo século XX. Rio de Janeiro: Contraponto. São Paulo: Ed. UNESP. 1996 [1994]. 
BM\&FBOVESPA. "Um mercado crescente para elevar o lucro das carteiras" in Revista Bovespa, abr/jun 2005. Internet. Acessado em 12/05/2010. http://www.bmfbovespa.com.br/InstSites/RevistaBovespa/94/Aluguel.shtml

Mercados Derivativos. (Série Introdutória). Internet. Acessado em 12/05/2010. http://www.bmfbovespa.com.br/pt-br/educacional/download/serie-introdutoria_mercadosderivativos.pdf

BOYER, Robert. A teoria da regulação: uma análise crítica. São Paulo: Nobel. 1990.

BRAGA, Ruy. A nostalgia do fordismo - elementos para uma crítica da Teoria Francesa da Regulação. IFCH/UNICAMP. Tese de doutorado. 2002.

"Dilemas do desenvolvimento: A empresa neoliberal e a hegemonia financeira". Extensão e Cultura (UFG), v. X, p. 26-33. 2008. Versão eletrônica (acessada em 15/07/2011): http://www.proec.ufg.br/revista_ufg/junho2008/Textos/dilemasDesenvolvimento.pdf

BRENNER, Robert. O boom e a bolha: Os Estados Unidos na economia mundial. Rio de Janeiro: Record. 2003.

. "What Is, and What Is Not, Imperialism?”. Historical Materialism. № 14:4, pp. 79105. 2006. Versão eletrônica (acessada em 15/07/2011): http://www.revalvaatio.org/wp/wpcontent/uploads/brenner-what is and what.pdf

BRUNO, Miguel. Crescimento econômico, mudanças estruturais e distribuição: as transformações do regime de acumulação no Brasil. Instituto de Economia/UFRJ. Tese de doutorado. 2005.

CARCANHOLO, Reinaldo, SABADINI, Mauricio. "Capital fictício e lucros fictícios" in: Revista Soc. Bras. de Economia Política. Rio de Janeiro. No 24. pp. 41-65. Junho/2009. Versão eletrônica (acessada em 15/07/2011): http://www.sep.org.br/revista artigo/revista241.pdf

CASTEL, Odile. "La naissance de l'ultra-impérialisme. Une interprétation du processus de mondialisation". In: DUMÉNIL, Gérard. LÉVY, Dominique (org.). Le triangle infernal. Crise, mondialisation, financiarisation. Paris: PUF. 1999. (Cap. 6, pp.121-139).

DOWBOR, Ladislau. "A crise financeira sem mistérios. Convergência dos dramas econômicos, sociais e ambientais". Julho/2009. Internet. Acessado em 20/02/2011. http://dowbor.org/crisesemmisterios8.pdf 
DUMÉNIL, Gérard. LÉVY, Dominique. "Superação da crise, ameaças de crises e novo capitalismo". In: CHESNAIS et al. Uma nova fase do capitalismo?. São Paulo: Xamã. 2003 [2001]. (Cap. 1, pp.15-41).

EICHENGREEN, Barry. A globalização do capital. São Paulo: Editora 34. 2000.

FAUSTO, Ruy. Marx: lógica e política (tomo III). São Paulo: Editora 34. 2002.

GOWAN, Peter. A roleta global. Rio de Janeiro: Editora Record. 2003.

GRESPAN, Jorge L. O negativo do capital. $O$ conceito de crise na crítica de Marx à economia política. São Paulo: HUCITEC/FAPESP. 1998.

GUTTMANN, Robert. "Basiléia II: uma nova estrutura de regulação para a atividade bancária global” in: MENDONÇA, Ana. ANDRADE, Rogério de (org.). Regulação bancária e dinâmica financeira: evolução e perspectivas a partir dos Acordos de Basiléia. Campinas: Unicamp. 2006. pp. 177-212.

HILFERDING, Rudolf. Capital Financeiro. São Paulo: Nova Cultural. Col.: Os Economistas. vol. 39.1985.

Le capital financier. Paris: Les Éditions de Minuit. 1970 [1910]. Versão eletrônica (acessada em 15/07/2011): http://www.marxists.org/francais/hilferding/1910/lcp/hilf_lcp.pdf (portanto há diferença de paginação em relação à versão impressa).

Finance Capital. A Study of the Latest Phase of Capitalist Development. Ed. Tom Bottomore (Routledge \& Kegan Paul, London, 1981). Versão eletrônica (acessada em 15/07/2011): http://www.marxists.org/archive/hilferding/1910/finkap/index.htm (portanto pode haver diferença de paginação em relação à versão impressa).

HORKHEIMER, Max. "A presente situação da filosofia social e as tarefas de um Instituto de Pesquisas Sociais”. In: Revista Praga, nº. São Paulo: Hucitec. 1999.

"Teoria tradicional e teoria crítica". In: . Textos escolhidos. São Paulo: Abril

Cultural. 1983.

HUSSON, Michel. "Finance, hyper-concurrence et reproduction du capital". In: CHESNAIS et al. La finance capitaliste. Paris: PUF. 2006. (Cap. 5, pp. 221-247).

KLAGSBRUNN, Victor. "Mundialização x Globalização e o papel das Finanças no capitalismo contemporâneo". Seminários REDEM. 2007. Internet. Acessado em 7/9/2010. www.redem.buap.mx/seminario/sem2007/victorhugo.doc 
LORDON, Fréderic. "Fechar a Bolsa?". Le monde Diplomatique Brasil. Fev/2010. Ano 3, No 31, pp-28-29.

Fonds de pension, piège à cons? Mirage de la démocratie actionnariale. Paris: Raison d'Agir. 2000.

LUKÁCS, Georg. História e consciência de classe: estudos sobre a dialética marxista. São Paulo: Martins Fontes. 2003.

MARX, Karl. O capital. Crítica da economia política. Volume I. São Paulo: Abril cultural. 1985a.

. O capital. Crítica da economia política. Volume II. São Paulo: Abril cultural. 1985b.

$1985 c$.

O capital. Crítica da economia política. Volume III. São Paulo: Abril cultural. 1986a.

O capital. Crítica da economia política. Volume IV. São Paulo: Abril cultural. . O capital. Crítica da economia política. Volume V. São Paulo: Abril cultural. 1986b.

O Dezoito Brumário de Louis Bonaparte. São Paulo: Centauro. 2000.

. As lutas de classes na França de 1848 a 1850. In: MARX, Karl. ENGELS, Friedrich. Obras Escolhidas. Vol I. pp 111-198. Rio de Janeiro: Editorial Vitória. 1956.

. Grundrisse: Foundations of the Critique of Political Economy. London: Penguin. 1973.

MARX, Karl. ENGELS, Friedrich. O manifesto comunista.. São Paulo: Paz e Terra. 1998. Coleção leitura.

MOESELEY, Fred (org.). Marx's Theory of Money: Modern Appraisals. Hampshire: Palgrave Macmillan. 2005.

MUSSE, Ricardo. "Introdução ao Manifesto Comunista". In: MARX, K. ENGELS, F. Manifesto Comunista. São Paulo: Hedra. 2010. 
NAKATANI, Paulo. HERRERA, Rémy. “Crise financeira... ou de superprodução?”. 2010. Artigo apresentado no XV Encontro Nacional de Economia Política da SEP. Internet. $\begin{array}{lll}\text { Acessado em 20/05/2010. } & \text { em }\end{array}$ http://www.sep.org.br/artigo/2006 bb54fc27abc7a37763231c7185ffbe43.PDF

NAKATANI, P. MARQUES, Rosa. "A finança capitalista: a contribuição de François Chesnais para a compreensão do capitalismo contemporâneo". Artigo apresentado no XXXVI Encontro da ANPEC. 2008. Internet. Acessado em 7/6/2010. http://www.anpec.org.br/encontro2008/artigos/200807211429380-.pdf

OCDE, Princípios da OCDE sobre o governo das sociedades. 2004. Internet. Acessado em 31/03/2010. http://www.oecd.org/dataoecd/1/42/33931148.pdf

OCDE, Comparison of gross domestic product (GDP) for OECD member countries. 2010. Internet. Acessado em 26/04/2010. http://www.oecd.org/dataoecd/48/4/37867909.pdf

OLIVEIRA, Francisco de. Crítica à razão dualista. São Paulo: Boitempo Editorial. 2003.

PAULANI, Leda. "A autonomização das formas verdadeiramente sociais na teoria de Marx: comentários sobre o dinheiro no capitalismo contemporâneo". XXXVII Encontro da ANPEC. 2009. Internet. Acessado em 19/05/2010. http://www.anpec.org.br/encontro_2009.htm

. "A crise do regime de acumulação com dominância da valorização financeira e a situação do Brasil" in Estudos Avançados. Vol. 23, № 66, 2009. Versão eletrônica (acessada em 04/07/2010): http://www.scielo.br/pdf/ea/v23n66/a03v2366.pdf

. "Resenha sobre Inside Job". In: Brasil de Fato. 09/05/2011. Versão eletrônica (acessada em 15/07/2011): http://www.brasildefato.com.br/node/6248

PAULANI, Leda. ALMEIDA FILHO, Niemeyer. "Regulação e social e acumulação por espoliação - reflexão sobre as teses da financeirização e a caracterização do capitalismo contemporâneo". XIV Encontro da SEP. 2009. Internet. Acessado em 05/05/2011. http://www.sep.org.br/artigo/4_congresso/1725_b13f862d0e7017cc778f6bff1c0a7d38.pdf

PLIHON, Dominique. "Au nom des entreprises". Le Monde Diplomatique. Fev/1999, p. 4. Internet. Acessado em 9/06/2010. http://www.mondediplomatique.fr/1999/02/PLIHON/11647

- "Desequilíbrios mundiais e instabilidade financeira: a responsabilidade das políticas liberais. Um ponto de vista keynesiano". In: CHESNAIS, F. (org.). A mundialização financeira: gênese, custos e riscos. São Paulo: Xamã. 1998 [1996]. (Cap. 4, pp. 97-139). 
PORTAL EXAME, "Sadia perde cerca de R\$2,5 bi com câmbio em 2008, diz Brascan". 27/01/2009. Internet. Acessado em 19/05/2010. http://portalexame.abril.com.br/negocios/sadia-perde-cerca-r-2-5-bi-cambio-2008-dizbrascan-417570.html

POSTONE, Moishe. "Teorizando o mundo contemporâneo: Robert Brenner, Giovanni Arrighi, David Harvey". In: Novos Estudos Cebrap. № 81. Julho/2008. pp.79-97. Versão eletrônica (acessada em 15/07/2011): http://www.scielo.br/pdf/nec/n81/08.pdf

PRADO, Eleutério. A desmedida do valor. São Paulo: Xamã. 2005.

. "Uma nova fase do capitalismo ou um novo modo de produção?", in Outubro, n¹3.

2006. Versão eletrônica (acessada em 05/05/2011):

http://www.usp.br/feaecon/biblioteca lista.php?a=3

. "Resenha de 'A finança mundializada", in: Outubro, n¹4, pp. 217-224. 2006.

Versão eletrônica (acessada em 15/07/2011): http://www.revistaoutubro.com.br/edicoes/14/out14_11.pdf

PRADO JR., Caio. Formação econômica do Brasil contemporâneo. São Paulo: Brasiliense. 1969.

SALAMA, Pierre. "A financeirização excludente: as lições das economias latinoamericanas". In: CHESNAIS, F. (org.). A mundialização financeira: gênese, custos e riscos. São Paulo: Xamã. 1998 [1996]. (Cap. 7, pp. 211-247).

SALAMA, Pierre. CAMARA, Mamadou. "A inserção diferenciada - com efeitos paradoxais - dos países em desenvolvimento na mundialização financeira”. In: CHESNAIS, F. (org.). A finança mundializada: raízes sociais e políticas, configuração, consequências. São Paulo: Boitempo. 2005 [2004]. (Cap. 8, pp. 199-221).

SERFATI, Claude. "O papel ativo dos grupos predominantemente industriais na financeirização da economia". In: CHESNAIS, F. (org.). A mundialização financeira: gênese, custos e riscos. São Paulo: Xamã. 1998 [1996]. (Cap. 5, pp. 141-181).

SHAIKH, Anwar. "La Primera Gran Depresión del Siglo XXI". In: Sinpermisso. Fev/2011. Internet. Versão eletrônica (acessada em 15/07/2011): http://www.sinpermiso.info/articulos/ficheros/XXI.pdf

SMITHIN, John (org.). What is money? London: Routledge. 1999. 
TEIXEIRA, Rodrigo. Dependência, desenvolvimento e dominância financeira. São Paulo. IPE/USP. Tese de doutorado. 2007.

WOLF, Martin. "O novo capitalismo financeiro provoca revolução global". Artigo traduzido do Financial Times e disponível no site do MST. 2007. Internet. Acessado em 7/6/2010. http://www.mst.org.br/node/4379

\section{Fontes eletrônicas de dados:}

- TREASURY DIRECT:

http://www.treasurydirect.gov/govt/reports/pd/histdebt/histdebt_histo4.htm ;

- US GOVERNEMENT SPENDING:

http://www.usgovernmentspending.com/downchart_gs.php?year=1792_2010\&view=1\&expa $\underline{\mathrm{nd}}=\&$ units $=\mathrm{p} \& \mathrm{fy}=\mathrm{fy} 11 \&$ chart $=\mathrm{H} 0$ -

fed\&bar $=0 \&$ stack $=1 \&$ size $=1 \&$ title $=$ US $\% 20$ Federal $\% 20$ Debt $\% 20 \mathrm{As} \% 20$ Percent $\% 20$ Of $\% 20 \mathrm{G}$ $\underline{\text { DP } \& \text { state }=\text { US \& color }=c \& l o c a l=s \# \text { copypaste }}$ 